\title{
Halogenated (Phenolic) Contaminants and Complex Mixtures in Model Gull Species and Competitive Binding Interactions With Major Thyroid Hormone Transport Proteins
}

By

Francisco Ucan-Marin

A Thesis Submitted to the Faculty of Graduate Studies and Research in Partial Fulfilment of the Requirements of the Degree of Doctor of Philosophy: Chemistry Specialization in Chemical and Environmental Toxicology at Carleton University

Francisco Ucan-Marin® 2009

Carleton University, Chemistry Department 
Library and Archives
Canada

Published Heritage Branch

395 Wellington Street

OttawaONK1A0N4

Canada
Bibliotheque et

Archives Canada

Direction du

Patrimoine de l'edition

395, rue Wellington

Ottawa ON K1A ON4

Canada
Your file Votre reference

ISBN: 978-0-494-63863-7

Our file Notre reference

ISBN: 978-0-494-63863-7
NOTICE:

The author has granted a nonexclusive license allowing Library and Archives Canada to reproduce, publish, archive, preserve, conserve, communicate to the public by telecommunication or on the Internet, loan, distribute and sell theses worldwide, for commercial or noncommercial purposes, in microform, paper, electronic and/or any other formats.

The author retains copyright ownership and moral rights in this thesis. Neither the thesis nor substantial extracts from it may be printed or otherwise reproduced without the author's permission.

In compliance with the Canadian Privacy Act some supporting forms may have been removed from this thesis.

While these forms may be included in the document page count, their removal does not represent any loss of content from the thesis.

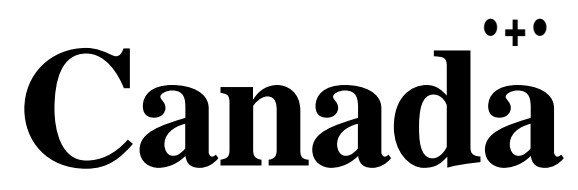

AVIS:

L'auteur a accorde une licence non exclusive permettant a la Bibliotheque et Archives Canada de reproduire, publier, archiver, sauvegarder, conserver, transmettre au public par telecommunication ou par l'Internet, prefer, distribuer et vendre des theses partout dans le monde, a des fins commerciales ou autres, sur support microforme, papier, electronique et/ou autres formats.

L'auteur conserve la propriete du droit d'auteur et des droits moraux qui protege cette these. $\mathrm{Ni}$ la these ni des extraits substantiels de celle-ci ne doivent etre imprimes ou autrement reproduits sans son autorisation.

Conformement a la loi canadienne sur la protection de la vie privee, quelques formulaires secondaires ont ete enleves de cette these.

Bien que ces formulaires aient inclus dans la pagination, il n'y aura aucun contenu manquant. 


\section{Abstract}

Herring gulls (Larus argentatus) are suitable avian bio-monitors of ecosystems. No studies exist examining the interaction between organohalogen contaminants (OHCs) and thyroid hormones (THs) in birds from the Great Lakes. Polychlorinated biphenyl (PCB), polybrominated diphenyl ether (PBDE) flame retardant congeners are environmentally relevant $\mathrm{OHCs}$, and as well as some of their hydroxylated $(\mathrm{OH})$ analogues and recently perfluorinated compounds (PFCs) have been reported to have effects on THs-dependent processes.

TH transport proteins albumin (ALB) and transthyretin (TTR) from livers and brain of herring and glaucous (Larus hyperboreus) gulls were isolated, cloned, sequenced, purified and expressed, and used for competitive binding assays (CBAs) in vitro and compared with human ALB and TTR.

This is the first report on circulating £OH-PCB, £OH-PBDE, £PBDE and £MeOPBDEs in herring gulls plasma and livers from the Laurentian Great Lakes. Results obtained shows that human ALB and TTR had higher preference for $\mathrm{T}_{4}$ relative to T3 whereas it was reversed for gull recALB and recTTR. Complex neutral chemical fractions isolated from plasma had no effects, but phenolic fraction disrupted $(p>0.001)$ the binding of human TTR with $T_{4}$, human ALB with $\mathrm{T}_{4}$, and the gull TTR with $\mathrm{T}_{3}$.

CBA with recALB and recTTR showed that relative to 2,2',4,4'-tetrabromoDE (BDE47) and 2,2',3,4',5,5',6-heptaCB (CB187) and the MeO-substituted (4-MeOCB187 and 6-MeO-BDE47) analogues, 4-OH-CB187, 6-OH-BDE47 and 4'-OHBDE49 had greater affinity than T3 or $\mathrm{T}_{4}$. Also, Perfluorooctanesulfonamide (PFOSAJ had effects of human TTR binding of $\mathrm{T}_{4}$; perfluoroundecanoic acid (PFUdA) had a disruptive effect on human and gull TTR binding to $T_{4}$, but no effect with T3. This is also the first report of PFCs in livers of herring gulls from the Great Lakes.

The combination of the more TH-like brominated diphenyl ether backbone (relative to the chlorinated biphenyl backbone), and having an $\mathrm{OH}$-group, results in a high competitive ligand on gull Albumine and TTR relative to T3 and $T_{4}$. While in PFCs the carboxylated polar head appears to have higher affinity for Albumin than $\mathrm{T}_{4}$ and $\mathrm{T}_{3}$. 


\section{Acknowledgements}

I would like to express a special appreciation to my supervisor Professor Dr. Robert J. Letcher, Carleton University Chemistry Department, for giving me the opportunity to carry out this work and for his generosity by involving me, not only in this, but also in other research and teaching projects over the years. In the past five years I have appreciated and learned a lot through his contributions in interesting discussions about diverse topics in environmental chemistry and wildlife ecotoxicology. Without his support, enthusiasm and his almost endless patience this thesis could not have been fulfilled.

I also express great thanks to Dr. Augustine Arukwe, Norwegian University of Science and Technology (NTNU), for his support with the molecular cloning, expression and purification of albumin and transthyretin and for his generous contributions in the publication process of the various papers and the present thesis.

Analyses of organochlorines were performed at the Laboratories of the National Wildlife Research Centre, Canadian Wildlife Service- Environment Canada. Molecular and Genetics work was carried out at the and at the Department of Biology (NTNU), in Trondheim, Norway. The project received financial support through the Natural Science and Engineering Research Council (NSERC) of Canada and Environment Canada's Chemicals Management Plan (to R.J.L.), and the Norwegian Research Council and Polar Institute.

Thanks to France Maisonneuve (NWRC, Environment Canada) for her assistance with the competitive binding assays, to Dr. Jonathan Verreault, Hallvard Strom and Rosa A. Villa (the Norwegian Polar Institute) for collection of glaucous gull samples from Bear Island; and to Dr. Anne Skjetne Mortensen and Chriptopher Sormoe for their guidance during rTTR and rALB synthesis (NTNU). Great thanks are expressed to Wouter Gebbink for the collection and identification of perfluorinated compounds. I would like to express deep thanks to research fellow Dr. Shaogang Chu for the support in the analysis of organochlorines at NWRC; also appreciation is expressed to my current and past Lab and Office colleagues, Soheila Shahmiri, Melissa McKinney, Lisa Mattioli, Stacey Robinson, Lewis Gauthier, Luke Periard, Eric Pelletier, Vie Vongphachan, Joanna James, and Antoine Caron for making possible a friendly work environment. I would like to thank the people at the NWRC and to the Carleton University Chemistry Department for providing a friendly and stimulating working environment.

I am indebted to my in-laws Dr. John and Barbara Salva for their unconditional support during my Doctoral studies, and to all my Ucan \& Marin Family in Mexico.

Finally, I will dedicate this work to my wife Monika and my daughter Mahalia Grace for their support and for bringing joy, motivation and calm at 'hard times' during the fulfilment of this thesis.

Ottawa, November 2009.

Francisco Ucan-Marin. 


\section{List of Publications and Conference Abstracts associated with Thesis.}

Ucan-Marin. F, Arukwe A, W.A. Gebbink, Letcher RJ Perfluoroalkyl Compounds (PFCs) and PFC-containing complex mixtures isolated from herring gull liver (Lake Ontario): Comparative in vitro competitive binding with thyroid hormones on gull and human albumin and transthyretin transport proteins. SETAC North America 30th Annual Meeting, 19-23 November 2009, New Orleans, USA.

Ucan-Marin. F, Arukwe A, Mortensen A, Gabrielsen GW, Fox, G, Letcher RJ. Recombinant transthyretin purification and competitive binding with organohalogen compounds in two gull species (Larus argentatus and Larus hyperboreus). Toxicological Sciences 107(2), 440-450 (2009).

Ucan-Marin. F, Arukwe A, Mortensen A, Gabrielsen GW, Fox, G, Letcher RJ. Recombinant albumin and transthyretin transport proteins from two gull species and human: Chlorinated and brominated contaminant binding and thyroid hormones. (Environmental Science and Technology, Article ASAP Publication Date (Web): December 3, 2009).

Ucan-Marin. F, Arukwe A, Mortensen A, Gabrielsen GW, Fox, G, Letcher RJ., (2009) Thyroidogenic brominated contaminants in two top predator gull species (Larus argentatus and Larus hyperboreus). 11th Annual Workshop on Brominated Flame Retardants BFR2009. May 19-20, 2009 Ottawa, Ontario

Ucan-Marin, F., Arukwe, A., Fox, G.A., Gabrielsen, G.W., and Letcher, R.J. (2006). Thyroid hormone transport in Great Lakes herring gull and Svalbard glaucous gull: Competitive transthyretin (TTR) binding of selected organohalogens. $26^{\text {th }}$ International Symposium on Halogenated Environmental Pollutants and POPs (DIOXIN'2006), Aug. 21-26, Oslo, Norway; Organohalogen Compounds, 68:281-284.

Ucan-Marin, F; A. Arukwe, G. Fox, G.W. Gabrielsen and R. Letcher (2006). Thyroid hormone transport in great lakes herring gull and Svalbard glaucous gull: competitive transthyretin (TTR) binding of selected organohalogens. Organohalogen Compounds 68: 281-284.

Ucan-Marin, F; A. Arukwe, G. Fox, G.W. Gabrielsen and R. Letcher., (2008). The use of competition binding potency of thyroid transport proteins from Larus argentatus and Larus hyperboreus for ecotoxicology risk assessment NWRCEnvironment Canada / Carleton University. Third Mexican Conference of Graduate Students and Researchers in Canada. October 24-26, 2008. CEIMEXCAN Montreal QC.

Ucan-Marin, F; A. Arukwe, G.W. Gabrielsen and R. Letcher., (2007). Effects of selected organohalogens on hormone transport proteins in an avian model: new advances. Carleton University Environmental Chemistry Ph.D. Program. 
Ecotoxicology, October 22, 2007. Second Mexican Conference of Graduate Students and Researchers in Canada, CEIMEXCAN Quebec City QC.

Ucan-Marin F, Arukwe A, Fox GA, Gabrielsen GW, Letcher, RJ., (2007). Cloning and Purification of thyroid transport protein transthyretin (pre-albumin) from Larus argentatus and Larus hyperboreus top avian predator models; and their competition binding potency on selected Organophenolic compounds. SETAC Europe 17th Annual Meeting, Porto, Portugal, 20-24 May 2007.

Ucan-Marin, F., Arukwe, A., Fox, G.A., Gabrielsen, G.W., and Letcher, R.J., (2006). Thyroid hormone transport in Great Lakes herring gull and Svalbard glaucous gull: Competitive transthyretin (TTR) binding of selected organohalogens. 26th International Symposium on Halogenated Persistent Organic Pollutants 2006, Oslo, Norway, August 21-25, 2006 


\section{Table of Contents}

Title

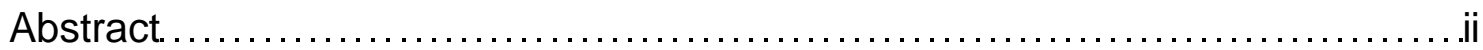

Acknowledgements ......................................................

List of Publications and Conference Abstracts associated with Thesis. . . . . . iv

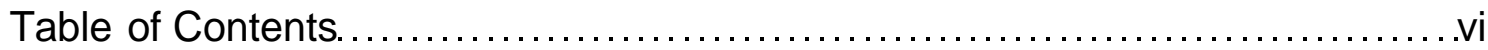

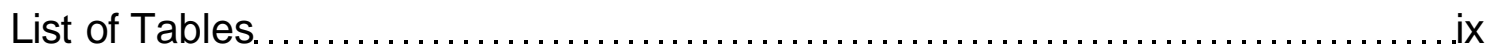

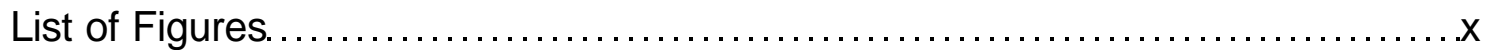

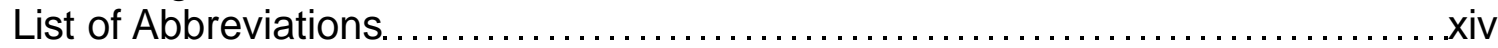

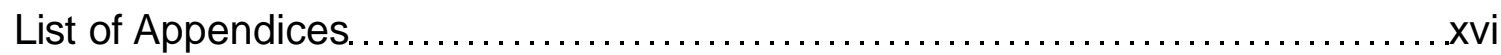

\section{CHAPTER ONE}

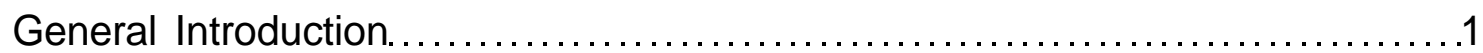

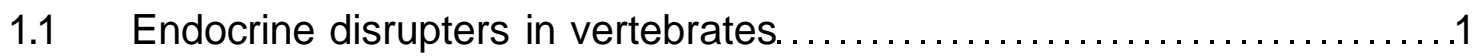

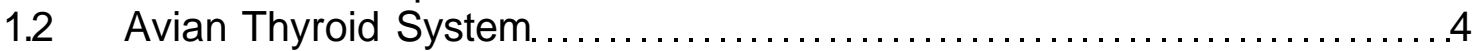

1.2.1 Thyroid Function ...........................................

1.2.2 Avian Thyroid Development................................ 8

1.2.3 Deiodination of Thyroid Hormones. .......................... 9

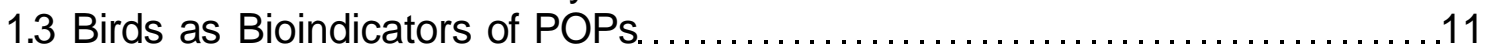

1.3.1 Introduction ................................................. 11

1.3.2 Factors affecting POPs accumulation in birds. ................16

1.3.3 Tissue Specific Accumulation in birds. .......................18

1.3.4 Using Birds as Bioindicators................................ 20

1.4 Endocrine Disrupting Compounds (EDCs) in Wildlife..................24

1.4.1 Endocrine Disrupting Compounds (EDCs) in Birds. . . . . . . . . 25

1.4.2 Thyroid hormones and Perfluorinated compounds. ...........28

1.4.3 Organohalogenated compounds and Avian Thyroid Hormones 29

1.4.4 Metabolites from organohalogens effects in avian thyroid

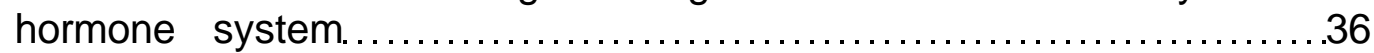

1.5 Selection of the Avian Models in this Study...............................39

1.5.1 Herring gulls in the Great Lakes..............................39

1.5.2 Glaucous Gull from Svalbard Island, Norway. ................ 44

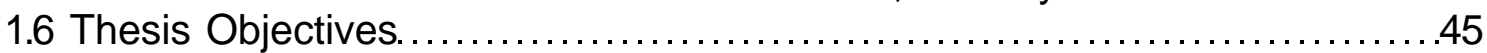

1.6.1 Project summaries. ......................................... 45

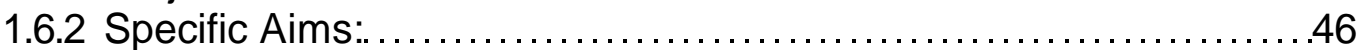

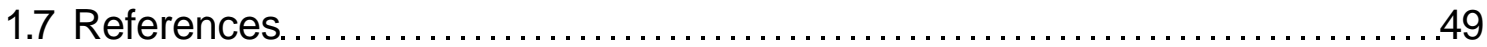

\section{CHAPTER TWO}

Material and Methods......................................................... 71

2.1 Samples collection, Gull liver and brain tissues.....................71

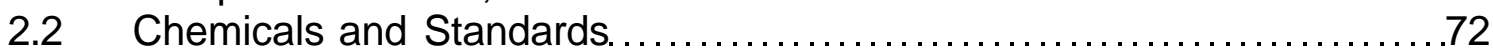

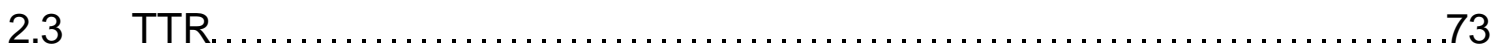

2.31 RNA isolation, cDNA synthesis and PCR ..................73 
2.3.2 TTR, Sequence analysis..................................74

2.3.3 Expression and purification of recombinant TTR (rTTR) . . . . . . .75

2.3.4 Competitive rTTR Binding..................................77

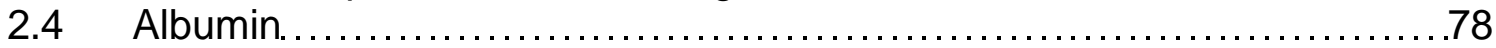

2.4.1 Albumin Cloning and Sequencing ..........................78

2.4.2 Expression and purification of recALB .................... 80

2.4.3 Substrate competitive binding with recALB $\ldots \ldots \ldots \ldots \ldots \ldots \ldots . .80$

2.5 Data analysis for Competitive Binding ........................... 81

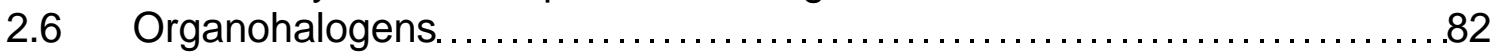

2.6.1 Extraction and Cleanup.................................... 82

2.6.2 Analysis and Quantification............................... 84

2.7 Perfluorinated compounds....................................... 85

2.7.1 Sample Preparation for PFCs ........................... 85

2.7.2 Instrumental Analysis.....................................87

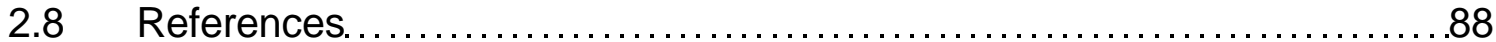

\section{CHAPTER THREE}

Recombinant Transthyretin Purification and Competitive Binding with Organohalogen compounds in Two Gull Species \{Larus argentatus and Larus hyperboreus).

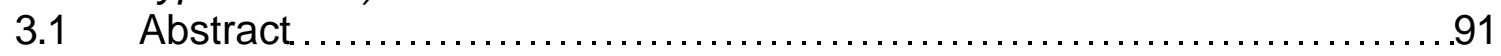

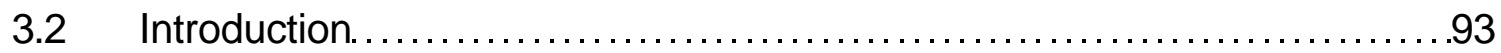

3.3 Results and Discussion. .........................................96

3.3.1 Cloning and characterization of gull recombinant TTR. . . . . .96

3.3.2 Competitive TTR binding assays..............................101

3.3.3 Phylogenetic analysis and comparison to other

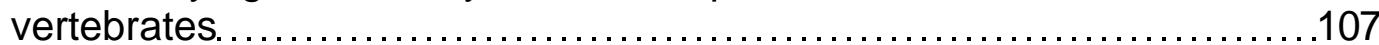

3.3.4 Natural T3 and T4 ligand binding to gull rTTR versus

human TTR ....................................................... 109

3.3.5 Competitive gull rTTR binding of T3 and T4 with exogenous contaminant ligands............................................. 111

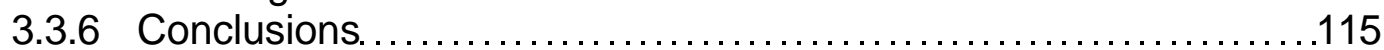

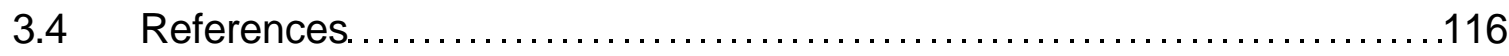

\section{CHAPTER FOUR}

Recombinant Albumin Transport Protein from gull species (Larus argentatus and hyperboreus) and Human: Chlorinated and Brominated Contaminant Binding and Thyroid Hormones.

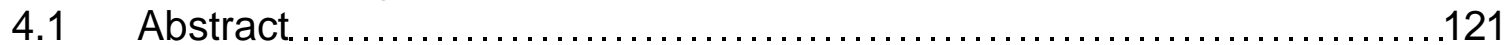

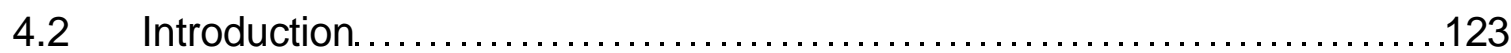

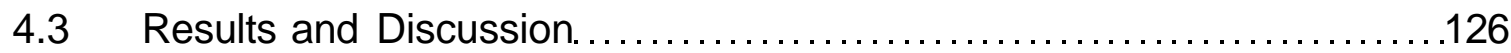

4.3.1 Cloning and characterization of gull albumin. ..............126

4.3.2 Substrate competitive binding with thyroid hormones. . . . . . . . 129

4.3.3 Phylogenetic comparison of gull albumin to other vertebrates................................................ 130

4.3.4 T3 and T4 ligand binding to gull recALB versus 
human recALB.

4.3.5 Competitive $\mathrm{T}_{3}$ or $\mathrm{T}_{4}$ binding of contaminant substrates with gullrecALB.

4.3.6 Implications of xenobiotic modulation of thyroid hormone transport.

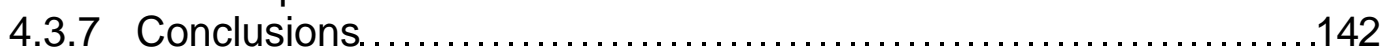

4.4 References.

\section{CHAPTER FIVE}

Organohalogens and Metabolites in the Blood and Livers of Lake Ontario Herring Gulls (Larus argentatus) and Competitive Binding of Complex

Mixture Fractions With Gull Thyroid Hormone Transport Proteins In Vitro.

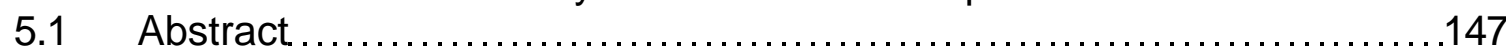

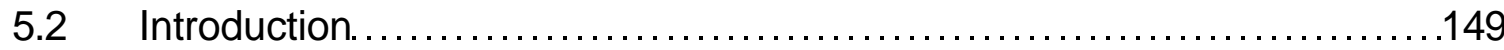

5.3 Results and Discussion............................................ 152

5.3.1 Contaminants in blood and liver of herring gulls from

Lake Ontario...................................................... 152

5.3.2 Organochlorine Compounds..............................153

5.3.3 Brominated Compounds....................................161

5.3.4 Novel Compounds Detected in Herring Gulls from the

Great Lakes........................................................ 165

5.3.5 Competitive binding of Complex Mixtures..................167

5.3.6 Comparison of Contaminants..............................168

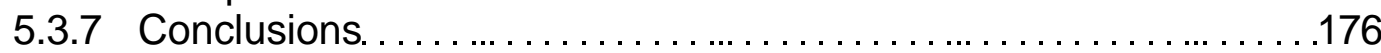

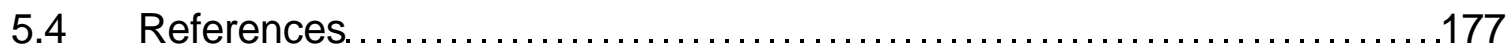

\section{CHAPTER SIX}

Perfluoroalkyl Compounds (PFCs) and PFC-containing complex mixtures isolated from herring gull liver (Lake Ontario): Comparative in vitro Competitive Binding with Thyroid Hormones on gull and Human Albumin and Transthyretin transport proteins

6.1 Abstract 187

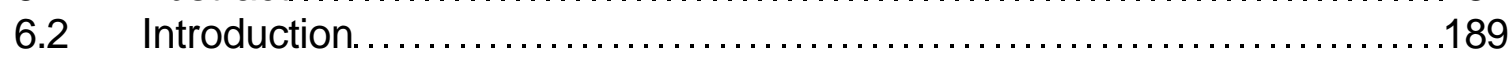

6.3 Results and Discussion.......................................... 194

6.3.1 Comparison of sites and contaminants......................194

6.3.2 Complex mixture of neutral and acidic extraction. . . . . . . . . 198

6.3.3 Conclusions ............................................ 210

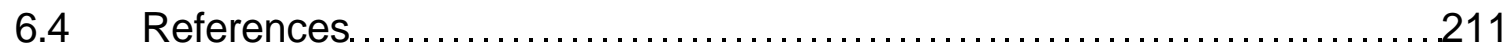

\section{CHAPTER SEVEN}

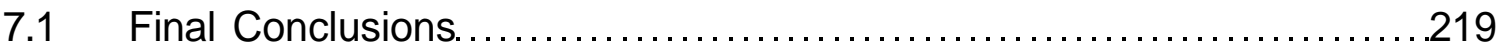

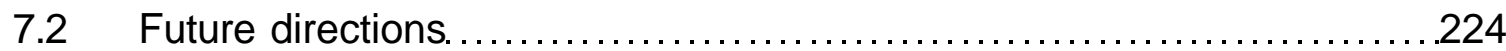

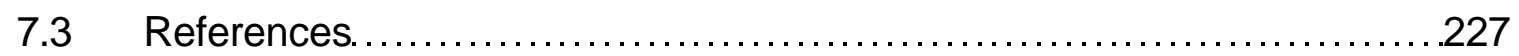




\section{List of Tables}

Table 1. Competitive Binding parameters for gull Transthyretin protein and 3,3',5-triiodo-L-thyronine (T3) and 3,5,3',5'-tetra-iodothyronine or thyroxine (T4) in the presence of model PCB and structural analogue congener ligands, and human TTR values for $T_{3}$ and $T_{4}$ as reference.

Table 2. Competitive Binding parameters for gull Transthyretin protein and T3 and T4 in the presence of model PBDE and structural analogue congener ligands.

Table 3. Competitive Binding parameters for recombinant gull albumin (ALB) and transthyretin (TTR) hormone transport proteins and $T_{3}$ and $T_{4}$, and in the presence of model PCB and substituted structural analogue ligands, and compared to recombinant human TTR and ALB with T3 and T4 for comparison.

Table 4. Competitive Binding parameters for recombinant gull albumin (ALB) and transthyretin (TTR) hormone transport proteins and T3 and $T_{4}$, and model PBDEs and substituted structural analogue ligands, and compared to recombinant human TTR and ALB with $T_{3}$ and $T_{4}$ for comparison.

Table 6. Arithmetic Mean, Standard Error (SE) and Data Range of concentrations of ${ }^{\wedge}$ compounds identified in plasma and liver of Herring gulls from Hamilton Harbour $(\mathrm{HH})$ and Scotch Bonnet Island (SB).

Table 7. Arithmetic Mean Concentration of £PFSA ( $\mathrm{ng} / \mathrm{g}$ we f vveight) in individual Herring gull livers collected from two colonies in the Great lakes; Hamilton Harbour $(\mathrm{HH})$ and Scotch Bonnet Island (SBI).

Table 8. Arithmetic Mean Concentration of £PFCA ( $\mathrm{ng} / \mathrm{g}$ wet weight) in individual Herring gull livers collected from two colonies in the Great Lakes; Hamilton Harbour $(\mathrm{HH})$ and Scotch Bonnet Island (SBI). 


\section{List of Figures}

Figure 1. Hypothalamic-pituitary-peripheral gland (H-P-PG) system

Figure 2. Basic deiodinase reactions. The reactions catalyzed by the deiodinases (D) remove iodine moieties (blue spheres) from the phenolic (outer rings) or tyrosil (inner rings) rings of the iodothyronines. These pathways can activate T4 by transforming it into T3 (via D1 or D2) or prevent it from being activated by converting it to the metabolically inactive form, reverse T3 (via D1 or D3). T2 is an inactive product common to both pathways that is rapidly metabolized by further deiodination (Bianco and Kim, 2006).

Figure 3. Role of transporters and deiodinases in the regulation of intracellular thyroid hormone levels and, thus, in thyroid hormone metabolism and action ( $R X R$, retinoid-X receptor; TR, thyroid hormone receptor; TRE, thyroid hormone response element; $D$, deiodinase) (Friesema et al, 2005).

Figure 4. Herring gull, Larus argentatus.

Figure 5. Map of Lake Ontario and the localization of the two colonies used in this study, Hamilton Harbour and Scotch Bonnet Island.

Figure 6. A multiple alignment of the predicted gull rTTR translation with TTRs from chicken, duck, crocodile, zebrafish, frog, human and rat was generated using MACAW. Identical and similar residues are indicated, darker shade corresponds to the most similar and no shade denotes any sequence homology. Accession numbers are: crocodile (CAA11129), frog (NP001081349), zebrafish (AAH81488), human (NP000362), rat (NP036813), chicken (NP990666), duck (ABC65926) and gull (sequence reported herein; EU352211).

Figure 7. Phylogenetic analysis of the amino acid sequences of TTR from several vertebrate species and Campylobacter coli. The tree was constructed using the neighbour-joining method and bootstrap values from 100 replicates. The sequence accession numbers of analysed genes are: Crocodile (CAA11129), frog (NP001081349), Zebrafish (AAH81488), human (NP000362), rat (NP036813), Chicken (NP990666), duck (ABC65926) and gull (EU352211). 
Figure 8. Purification of gull recombinant TTR (rTTR) expressed in E.coli BL21-RIPL. The electrophoretic gel shows eluants from a step-wise imidazole gradient with (from left to right) 250,300 and $500 \mathrm{mM}$ imidazole concentrations, and the his-tag labelled gull rTTR protein is observed as a monomer of $18 \mathrm{kDa}$ and homodimer of $36 \mathrm{kDa}$ that is comprised of the two-monomer forms.

Figure 9. Concentration-dependent, competitive binding curves of gull transthyretin (gTTR) and commercially available human transthyretin (hTTR) with 3,3',5-triiodo-L-thyronine $\left(\mathrm{T}_{3}\right)$ and 3,5,3',5'-tetra-iodothyronine or thyroxine $\left(T_{4}\right)$.. The error bars denote the standard deviation of $n=6$ replicated (two $n=3$ replicate sets performed on different days).

Figure 10. Concentration-dependent, competitive binding curves of $(A) T_{4}$ and (B) T3 displacement from gull transthyretin by 2,2',3,4',5,5',6-heptaCB (CB-187), 4-hydroxy-CB187 (4-OH-CB187) or 4-methoxy-CB187 (4-MeOCB187). The competitive binding parameters are listed in Table 1. The error bars denote the standard deviation of $n=6$ replicated (two $n=3$ replicate sets performed on different days).

Figure 11. Concentration-dependent, competitive binding curves of $(A) T_{4}$ and (B) T3 displacement from gull transthyretin by 2,2',4,4'-tetrabromoDE (BDE-47) flame retardant and 6-hydroxy-BDE47 (6-OH-BDE47), 6methoxy-BDE47 (6-MeO-BDE47) or 4-OH-2,2',4,5-tetrabromoDE (4-OHBDE49). The competitive binding parameters are listed in Table 2. The error bars denote the standard deviation of $n=6$ replicated (two $n=3$ replicate sets performed on different days).

Figure 12. Multiple alignments of recombinant gull albumin sequence with serum albumin sequences from chicken, gecko, rat, human, frog and salmon was generated using MACAW. GenBank accession numbers are: Larus sp. (temp access \# Icl|50720), Gallus gallus (NP_990592), Hoplodactylus maculatus (AF375972), Homo sapiens (AAX63425), Rattus norvegicus (NP599153), Xenopus laevis (NP001081244) and Salmo salar (P21848).

Figure 13. Phylogenetic analysis of the amino acid sequences of albumin of vertebrate species. The amino acid sequences of albumin were aligned using ClustalW analysis, and Bootstrap values based on 100 samplings. The osmotic stress-induced proline dehydrogenase sequence of Arabidopsis thaliana (accession no. AAB40615) was used as outgroup. The other protein accession numbers used; Larus sp. (temp access \# Icl|50720), Gallus gallus (NP_990592), Hoplodactylus maculatus (AF375972), Homo sapiens (AAX63425), Rattus norvegicus (NP599153), Xenopus laevis (NP001081244) and Salmo salar (P21848). 
Figure 14. Concentration-dependent, competitive binding curves for recombinant gull albumin (gALB) and transthyretin (gTTR), and recombinant human hALB and hTTR, with T3 or T4 Areas in brackets denote contrasting competitive binding concentrations and parameters (Table 1) for TTR and ALB.

Figure 15. Concentration-dependent, competitive binding curves (percent relative to controls; $n=9$ replicates, three sets of $n=3$ triplicate sets performed on different days) for (A) $T_{3}$ and (B) $T_{4}$ displacement from gull recALB by 2,2',3,4',5,5',6-heptaCB (CB-187), 4-hydroxy-CB187 (4-OHCB187) or 4-methoxy-CB187 (4-MeO-CB187). The competitive binding parameters are listed in Table 1. Concentration ranges in brackets denote blood plasma concentrations recently reported in Norwegian (Svalbard) glaucous gulls (Letcher et al. 2009; Verreault et al. 2005a).

Figure 16. Concentration-dependent, competitive binding curves (percent relative to controls; $n=9$ replicates, three sets of $n=3$ triplicate sets performed on different days) for (A) T3 and (B) T4 displacement from gull recALB by 2,2 ', 4,4'-tetrabromoDE (BDE-47) flame retardant and 6hydroxy-BDE47 (6-OH-BDE47), 6-methoxy-BDE47 (6-MeO-BDE47) or 4$\mathrm{OH}-2,2$ ', 4,5-tetrabromoDE (4-OH-BDE49). The competitive binding parameters are listed in Table 2. Concentration ranges in brackets denote blood plasma concentrations recently reported in Norwegian (Svalbard) glaucous gulls (Letcher et al. 2009; Verreault et al. 2005b).

Figure 17. Extracted fraction-dependent, competitive binding assay for recombinant gull albumin (gALB) and transthyretin (gTTR), and recombinant human hALB and hTTR, with T3 or T4 in presence of Neutral Fraction (SE \pm ). Percentage of competitive binding is based in control ${ }^{125} \mathrm{I}$ $\mathrm{T}_{4}$ and ${ }^{12 \star} \mid-\mathrm{T}_{3}$.

Figure 18. Extracted fraction-dependent, competitive binding assay for recombinant gull albumin (gALB) and transthyretin (gTTR), and recombinant human hALB and hTTR, with T3 or T4 in presence of Phenolic fraction (SE \pm ). Percentage of competitive binding is based in control ${ }^{125} \mathrm{I}-\mathrm{T}_{4}$ and ${ }^{\wedge 25} \mathrm{I}-\mathrm{T}_{3}$.

Figure 19. Proportions of the 4 tissues compared and their colony location plotted using the two first principal components (PCs), PC 1 and PC 2. Mean ( \pm 1 standard error) factor scores (right biplot) are showed for Hamilton Harbour and Scotch Bonnet Island. The percent variability explained by PC 1 and PC 2 is provided. 
Figure 20. Proportions of 9 major chlorinated and brominated contaminant classes or individual compounds plotted using the two first principal components (PCs); PC 1 and PC 2. Mean ( \pm 1 standard error) factor scores (right biplot) are showed. The percent variability explained by PC 1 and $\mathrm{PC} 2$ is provided.

Figure 21. Human or Gull Albumin and Transthyretin (TTR): Competitive binding of Perfluoroundecanoic acid (PFUdA) $\mathrm{CF}_{3}\left(\mathrm{CF}_{2}\right) 9 \mathrm{CO}_{2} \mathrm{H}(\mathrm{Cn}$ chain length) with T3 and T4.

Figure 22. Chemical structure of two typical perfluorinated substances. (A) $\begin{array}{lll}\text { Perfluorooctane sulfonamide } & (\mathrm{PFOSA}) & \mathrm{CF}_{3}(\mathrm{CF} 2) 7 \mathrm{SO}_{2} \mathrm{NH} 2 \text {, } \\ \text { Perfluoroundecanoic acid (PFUdA) } & \mathrm{CF}_{3}\left(\mathrm{CF}_{2}\right) 9 \mathrm{CO}_{2} \mathrm{H} .\end{array}$ (B) 202

Figure 23. Human or Gull Albumin and Transthyretin (TTR): Competitive binding of Neutral PFC-containing fractions from L. Ont. Herring gull Liver 204 with T3 and T4.

Figure 24. Human or Gull Albumin and Transthyretin (TTR): Competitive binding of Acidic fraction PFC-containing fractions from Lake Ontario. Herring gull Liver with 3,3',5-triiodo-L-thyronine $\left(T_{3}\right)$ and S.S.S'.S'-tetra- 206 iodothyronine or thyroxine (T4).

Figure 25. Human or Gull Albumin and Transthyretin (TTR): Competitive binding of Perfluorooctane sulfonamide (PFOSA) $\mathrm{CF}_{3}\left(\mathrm{CF}_{2}\right)_{7} \mathrm{SO}_{2} \mathrm{NH}_{2}$ with 207 $\mathrm{T}_{3}$ and $\mathrm{T} 4$. 


\section{List of Abbreviations}

$\begin{array}{ll}\text { AhR } & \text { Aryl hydrocarbon receptor } \\ \text { APPI } & \text { Atmospheric pressure, photo-ionization } \\ \text { BAT } & \text { Brown adipose tissue } \\ \text { CHL } & \text { Chlordane compounds } \\ \text { CNS } & \text { Central nervous system } \\ \text { CPs } & \text { Chlorinated paraffins } \\ \text { DDT } & \text { Dichlorodiphenyltrichloroethane } \\ \text { DDE } & \text { Dichlorodiphenyldichloroethylene } \\ \text { DNA } & \text { Deoxyribonucleic acid } \\ \text { DHEA } & \text { Dehydroepiandrosterone } \\ \text { ECNI } & \text { Electron capture negative ionization } \\ \text { EC-NWSB } & \text { Environment Canada's National Wildlife Specimen Bank } \\ \text { EDC } & \text { Endocrine disrupting compounds } \\ \text { El } & \text { Electron impact } \\ \text { EROD } & \text { Ethoxyresorufin-O-deethylase } \\ \text { ESI } & \text { Electrospray ionization } \\ \text { FOSAs } & \text { Perfluorooctane sulfonamides } \\ \text { FTOHs } & \text { Fluorotelomer alcohols } \\ \text { FTUCAs } & \text { Fluorotelomer unsaturated carboxylic acids } \\ \text { GH } & \text { Growth hormone } \\ \text { GLHGMP } & \text { Great Lakes Herring Gull Monitoring Program } \\ \text { HBB } & \text { Hexabromobenzene } \\ \text { HBCD } & \text { (a)-hexabromocyclododecane } \\ \text { H-P-PG } & \text { Hypothalamic-pituitary-peripheral gland } \\ \text { HPT } & \text { Hypothalamic-pituitary-thyroid axis } \\ \text { HCH } & \text { Hexachlorocyclohexanes } \\ \text { HCB } & \text { Hexachlorobenzene } \\ \text { HH } & \text { Hamilton Harbour } \\ \text { His-Trap-FF } & \text { Histidine-tagged Protein Purification } \\ \text { GC-MS } & \text { Gas chromatography-mass spectrometry } \\ \text { MeO } & \text { Methoxylated } \\ \text { MeS02-CB } & \text { Methylsulfonyl PCB } \\ \text { MeSO } 2-D D E ~ & \text { Methylsulfonyl DDE } \\ \text { mRNA } & \text { Messenger ribonucleic acid } \\ \text { MRM } & \text { Multiple reaction monitoring } \\ \text { NCBI } & \text { National Center for Biotechnology Information } \\ \text { NTNU } & \text { Norwegian University of Science and Technology } \\ \text { LN2 } & \text { Liquid nitrogen } \\ \text { PBDEs } & \text { Polybrominated diphenyl ethers } \\ \text { PCA } & \text { Principal Component analysis } \\ \text { PCB } & \text { Polychlorinated biphenyls } \\ \text { PCDD } & \text { Polychlorinated dibenzo-p-dioxins } \\ \text { PCDF } & \end{array}$




$\begin{array}{ll}\text { PCR } & \text { Polymerase chain reaction } \\ \text { PFCs } & \text { Perfluorinated Compounds } \\ \text { PFCAs } & \text { Perfluoroalkylcarboxylates } \\ \text { PFOS } & \text { Perfluorooctane Sulfonate } \\ \text { PFSAs } & \text { Perfluoroalkylsulfonates } \\ \text { P450 } & \text { Cytochrome P450 } \\ \text { POP } & \text { Persistent organic pollutants } \\ \text { PBT } & \text { Pentabromotoluene } \\ \text { recALB } & \text { recombinant albumin } \\ \text { recTTR } & \text { recombinant transthyretin } \\ \text { RBP } & \text { Retinol-binding protein } \\ \text { rT } & 3,3^{\prime} 5^{\prime}-\text { triodo-L-thyronine } \\ \text { T }_{4} & \text { thyroxine } \\ \text {T}_{3} & 3,3^{\prime}, 5 \text {-triiodothyronine } \\ \text { TCDD } & \text { 2,3,7,8-tetrachlorodibenzo-p-dioxin } \\ \text { TEF } & \text { Toxic equivalency factor } \\ \text { TEQ } & \text { Dioxin toxic equivalent } \\ \text { THs } & \text { thyroid hormones } \\ \text { THBPs } & \text { Thyroid hormone binding proteins } \\ \text { TRH } & \text { Thyrotropin-releasing hormone } \\ \text { TRa } & \text { Thyroid receptor alpha } \\ \text { TRP } & \text { Thyroid receptor beta } \\ \text { TSH } & \text { Thyroid stimulating hormone } \\ \text { TT } & \text { Total Thyroxine } \\ \text { TT } & \text { Total Triiodothyronine } \\ \text { OH } & \text { Hydroxylated } \\ \text { OC } & \text { Organochlorines } \\ \text { OHCs } & \text { Organohalogen contaminants } \\ \text { SB } & \text { Scotch bonnet Island } \\ \text { UDPGT } & \text { Uridine diphosphoglucuronosyl transferase activity } \\ 4-O H-H p C S & \text { 4-OH-heptachlorostyrene } \\ & \end{array}$




\section{List of Appendices}

Appendix I. Concentration levels of organohalogens and metabolites analyzed in plasma and liver of two herring gull colonies in Lake Ontario, Canada. 


\section{CHAPTER ONE}

\section{General Introduction}

\subsection{Endocrine system in Vertebrates}

The endocrine system is a complex network of glands and hormones that regulates many of the body's functions; including growth, development and maturation, as well as the way various organs operate. The endocrine glands including the pituitary, thyroid, adrenal, thymus, pancreas, ovaries, and testes release carefully-measured amounts of hormones into the bloodstream that act as natural chemical messengers, traveling to different parts of the body in order to control and adjust many life functions (NRDC 2009).

Vertebrates (Phylum Chordata: Vertebrata) are separable into at least seven discrete classes that represent evolutionary groupings of related animals with common features. The class Agnatha, or the jawless fish, is the most primitive group. Class Chondrichthyes and class Osteichthyes are jawed fishes that had their origins, millions of years ago, with the Agnatha. The Chondrichthyes are the cartilagous fishes, such as sharks and rays, while the Osteichthyes are the bony fishes. Familiar bony fishes such as goldfish, trout, and bass are members of the most advanced subgroup of bony fishes, the teleosts, which developed lungs and first invaded land. From the teleosts evolved the class Amphibia, which includes 
frogs and toads (EBO 2009). The amphibians gave rise to the class Reptilia, which became more adapted to land and diverged along several evolutionary lines. Among the groups descending from the primitive reptiles were turtles, dinosaurs, crocodilians (alligators, crocodiles), snakes, and lizards. Birds (class Aves) and mammals (class Mammalia) later evolved from separate groups of reptiles. Amphibians, reptiles, birds, and mammals, collectively, are referred to as the tetrapod (four-footed) vertebrates. The endocrine system of the tetrapod vertebrates is the product of millions of years of evolution, and consequently the endocrine glands and associated hormones of the human endocrine system have their counterparts with more primitive vertebrates. By examining these animals, it is possible to document the emergence of the hypothalamic-pituitarytarget organ axis, as well as many other endocrine glands, during the evolution of fishes that preceded the origin of terrestrial vertebrates (EBO 2009).

The hypothalamic-pituitary-peripheral gland (H-P-PG) endocrine (see Glossary) system (Figure 1) couples the vertebrate central nervous system (CNS) to peripheral organs (Norris 1997; Weichert 1953). A wide variety of ligands from the hypothalamus in the CNS regulate the release of hormones from the nearby pituitary gland. These hormones regulate the production of other hormones by the peripheral endocrine glands. Feedback loops complete the network of communication between the tissues of the system. The H-P-PG system regulates growth, metabolism, reproduction and response to stress. 


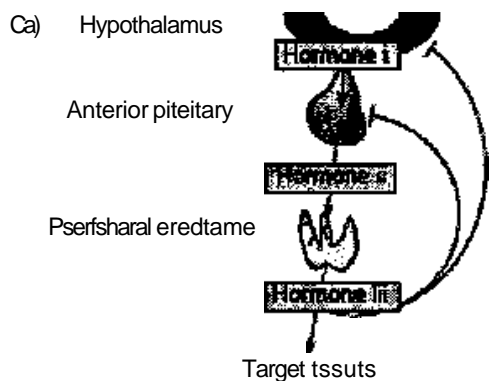

$\$$

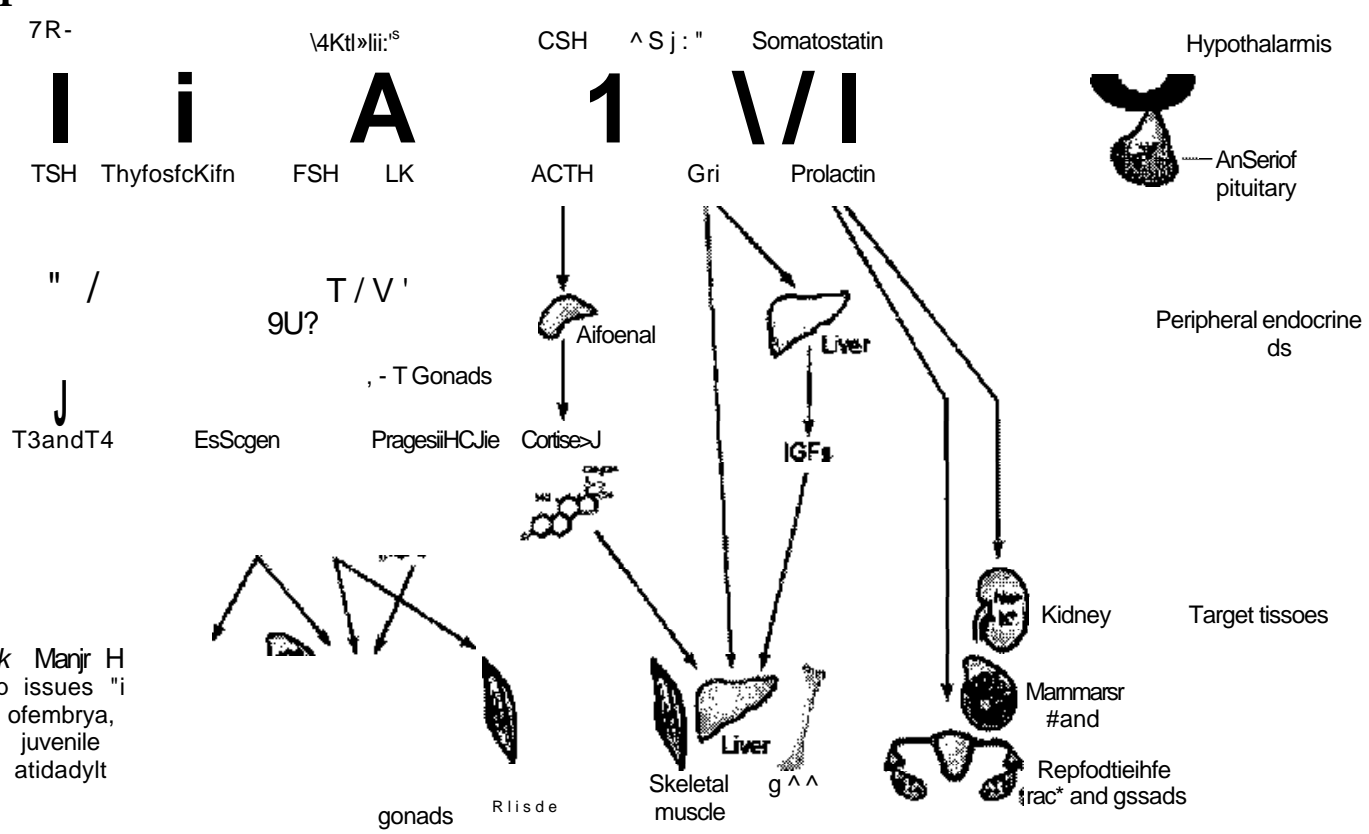

iRENOfte estates

Figure 1. (a) Hypothalamic-pituitary-peripheral gland (H-P-PG) system. The vertebrate H-P-PG system generally shows three levels of ligand-receptor systems. Ligands that are produced by the hypothalamus (i) in the central nervous system (CNS) regulate the release of hormones from the nearby pituitary gland (ii). Pituitary hormones regulate the production of other hormones by peripheral endocrine glands (iii). Hormones from the peripheral endocrine glands can in turn influence functions of the hypothalamus and pituitary, forming positive or negative (shown in the figure) feedback loops, (b) Examples of vertebrate H-P-PG system connection to target tissues. The H-P-PG system coordinates physiological functions of diverse tissues in response to internal and external environments. Abbreviations: $\mathrm{ACTH}$, adrenocorticotropic hormone; $\mathrm{CRH}$, corticotropin releasing hormone; $\mathrm{FSH}$, follitropin; $\mathrm{GH}$, growth hormone; GRF, growth hormone releasing factor; $\mathrm{GnRH}$, gonadotropin releasing hormone; IGF, insulin-like growth factor; $\mathrm{LH}$, lutropin; $\mathrm{TRH}$, thyrotropin-releasing hormone; TSH, thyrotropin; T3, triiodothyronine; T4, tetraiodothyronine (thyroxine) (Source: Campbell et al, 2004). 
Each of these physiological functions is regulated by a subset of H-P-PG ligands and receptors. This system appears highly conserved across vertebrates (i.e. from fish to mammals). Although the general scheme of linking neural and endocrine systems is also seen in invertebrates, there appears to be little conservation of the vertebrate H-P-PG tissues, ligands and receptors in invertebrates (Adams et al 2000).

\subsection{Avian Thyroid System}

\subsubsection{Thyroid Function}

The vertebrate thyroid gland secretes two hormones, thyroxine (T4), and triiodothyronine $\left(T_{3}\right)$ that are important for development and metabolism. $T_{4}$ is the most abundant hormone, whereas $T_{3}$ is the most active with respect to its function in biological systems (i.e., main hormone that binds to nuclear receptor). The thyroid gland is under the control of the hypothalamic-pituitary-thyroid (HPT) axis. Thyrotropin-releasing hormone $(\mathrm{TRH})$, from the hypothalamus, stimulates the release of thyroid stimulating hormone $(\mathrm{TSH})$, from the anterior pituitary, which in turn causes the thyroid gland to produce and release hormone. TH feedback to the anterior pituitary regulates the control of TSH production, as well as TRH release, which is also modulated by feedback from TSH (McNabb 1992). TSH stimulation of the thyroid gland increases when circulating concentrations of thyroid hormones (THs) are low. Although small amounts of T3 are produced by the thyroid gland, most of the T3 in the body is produced by deiodination of $T_{4}$. Deiodination of $T_{4}$ occurs when iodine atoms are removed from either the 
phenolic (outer) or tyrosyl (inner) ring. In $5^{\prime}$-deiodination $\left(5^{\prime} \mathrm{D}\right)$, iodine is removed from the outer ring of $\mathrm{T}_{4}$ yielding $\mathrm{T} 3$ (the most active hormone), and in 5deiodination (5D), an iodine atom is removed from the inner ring, yielding $\mathrm{rT}_{3 \mathrm{i}}$ which is inactive (Figure 2 and 3 ). These products can then be deiodinated further to yield diiodothyronines $\left(T_{2}\right)$ (other inactive form). There are three types of deiodination (D) pathways: type 1, type 2, and type 3. Type 1 (D1) deiodination provides a circulating source of $T_{3}$ to peripheral tissues. This type of deiodination is found mainly in the thyroid, liver, and kidney. Hyperthyroidism causes D1 to increase and hypothyroidism causes it to decrease, (i.e. the enzyme activity is substrate driven). Type 2 deiodination (D2) occurs in the brain, pituitary, and brown adipose tissue (BAT). In the brain and pituitary, T3 produced by D2I remains largely within the tissue where it is produced, maintaining the intracellular $T_{3}$ supply at euthyroid levels despite hypothyroid conditions in the rest of the body. In mammals, when T3 is limited, BAT type $25^{\prime} \mathrm{D}$ releases T3 to peripheral tissues, providing a circulating source of T3. In a hyperthyroid state, D2 decreases its activity. Type 3 deiodination (D3) involves removal of an iodine atom from the inner ring of iodothyronines (Figure 2). It is a major route for T3 degradation and inactivation of T4, producing rT3 (Leonard and Koehrle, 1996), consequently the role of transporters and deiodinases in the regulation of intracellular TH levels and, thus, in TH metabolism and action (Friesema et al, 2005) (Figure 3). 


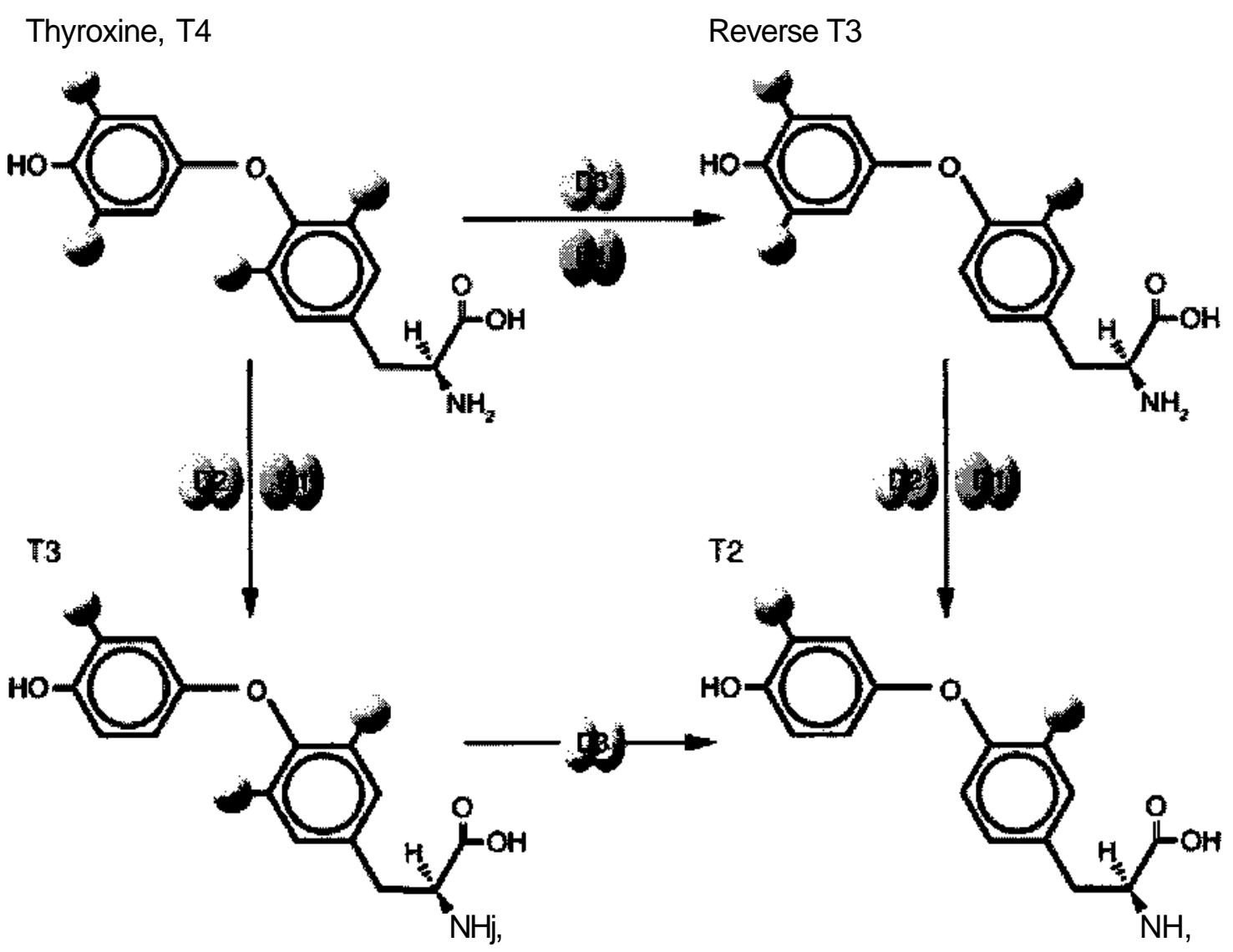

Figure 2. Basic deiodinase reactions. The reactions catalyzed by the deiodinases (D) remove iodine moieties (blue spheres) from the phenolic (outer rings) or tyrosil (inner rings) rings of the iodothyronines. These pathways can activate T4 by transforming it into T3 (via D1 or D2) or prevent it from being activated by converting it to the metabolically inactive form, reverse T3 (via D1 or D3). T2 is an inactive product common to both pathways that is rapidly metabolized by further deiodination (Bianco and Kim, 2006). 

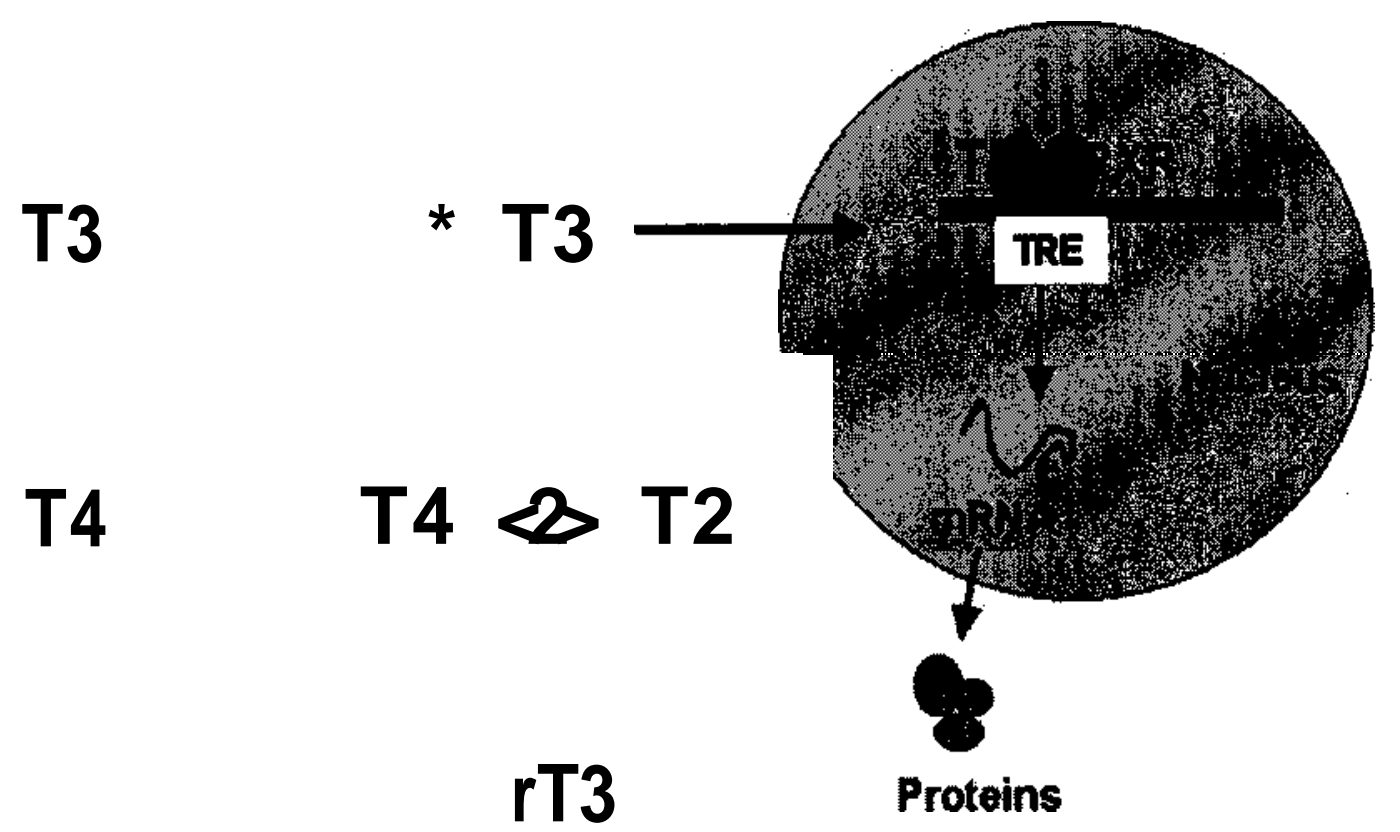

Figure 3. Role of transporters and deiodinases in the regulation of intracellular thyroid hormone levels and, thus, in thyroid hormone metabolism and action (RXR, retinoid-X receptor; TR, thyroid hormone receptor; TRE, thyroid hormone response element; D, deiodinase) (Friesema et al, 2005).

Binding proteins transport THs in the blood and ensure sustained $\mathrm{TH}$ supply to tissues despite fluctuations in thyroid gland function. They are present in different concentrations, with different numbers of hormone binding sites depending on the species. TTR, the major binding protein in mammals, binds to T4 with greater affinity than $T_{3}$, and the amount of hormone bound greatly exceeds the amount of free hormone in circulation. TH transport proteins play important roles in the availability and distribution of $\mathrm{THs}$ in the extracellular and intracellular compartments, and thus in regulating $\mathrm{TH}$ metabolism and kinetics (McNabb 1992) (Figure 3). 
THs in birds regulate metabolic heat production (thermoregulation), growth, body weight, development of central nervous system, cell differentiation and maturation, hatching, molt, and reproduction (McNabb 2000; Merryman and Buckles 1998a, 1998b). lodine, an essential element for TH synthesis, is stored in excess as iodide from dietary uptake (McNabb 1992). Avian THs are carried in the plasma bound to transport proteins, that is, albumin or TTR. Bird $T_{4}$ has been associated mostly with albumin, which has low-affinity binding sites with little specificity for $T_{4}$ or $T_{3}$ compared with TTR in mammals (Astier 1980; Davidson et al 1978; Merryman and Buckles 1998a). Factors that influence thyroid functions include dietary iodine (I-) availability, activity, ambient temperature, photoperiod, body condition, seasonality, and age (McNabb 2000).

\subsubsection{Avian Thyroid Development}

Avian developmental patterns range from chicks that are independent at the time of hatching (precocial) to those that are completely dependent on parental care after hatching (altricial). Precocial birds, like domestic chickens and Japanese quail, have their eyes open, are covered with down feathers, are capable of locomotion and self-feeding at hatching and show metabolic responses to cooling starting from time of hatching. In contrast, altricial birds as pigeons, sparrows and starlings, have closed eyes, lack down, are incapable of locomotion and are completely dependent on parental care for some period after hatch (Starck and Ricklefs 1998). 
Altricial birds have relatively immature thyroid function at hatch. Their thyroid function increases post hatch and stabilizes at about the time when they develop thermoregulation (McNabb and Cheng 1985). TH concentrations are low at hatching and do not increase until several weeks after hatching, these different patterns of avian thyroid development have implications for the time during which chemical pollutants are likely to alter thyroid function and cause other downstream effects on morphology and physiological development (McNabb and King 1993). The thyroid glands are controlled by the HPT axis for precocial birds by mid incubation/gestation and after hatching for altricial birds (Thommes 1987; Freeman and McNabb 1991).

There is a lack of information about herring gulls and glaucous gull regarding their thyroidogenic system; and more studies are necessary to improve the knowledge of the mechanistic interactions between the $\mathrm{TH}$ transport proteins and THs in birds.

\subsubsection{Deiodination of Thyroid Hormones}

At hatch, the chicks of various species of birds differ markedly in the degree of maturation of many aspects of their behavior, physiology, and anatomy. Variation among taxa in these developmental characteristics has led to the separation of avian species into precocial and altricial developmental types. The two main groups of hormones involved in growth in birds are growth hormone (GH) 
together with the associated insulin-like growth factors, and $\mathrm{T} 4$ and $\mathrm{T}_{3}$. Normal growth of post hatching birds requires $\mathrm{GH}, \mathrm{T} 4$ and $\mathrm{T}_{3}$ (Decuypere et al 2005).

TTR and albumin are the most important transport proteins of THs; however there are few studies that provide evidence of the binding properties and the specific targets (T4/T3) for transport proteins. TTR belongs to a group of proteins, which includes TBG and albumin, which binds to and transports THs in the blood. TTR is also indirectly implicated in the carriage of vitamin A through the mediation of retinol-binding protein (RBP) (Decuypere et al 2005). Hormonal control of avian growth has almost exclusively been studied in poultry species. More work on wildlife birds are necessary, to confirm our current views of hormonal control of developmental differences and the role of hormone protein carriers. The present thesis examines the hormonal control of growth in several species of the genus Larus, all of which are not domesticated birds.

The generally accepted model of THs action assumes that T3 is the primary hormone and that the principal function of $\mathrm{T}_{4}$ is to serve as a precursor of $\mathrm{T} 3$ in the deiodination of T4 by iodothyronine deiodinases (Oppenheimer 1983). The hypothesis holds that $T_{3}$ is bound to nuclear receptors (T3-R) with greater affinity than T4 and that an interaction of the hormone with the receptor initiates a cascade of nuclear events that results in the augmentation or inhibition of expression of those genes to which the T3-T3R complex binds. One of the benefits derived from the peripheral conversion of T4 to T3 is that the slower 
fractional turnover of $T_{4}$ compared with that of $T_{3}$ helps to stabilize the level of circulating $T_{3}$. The level of serum $T_{4}$ plays an additional role in THs homeostasis. In states characterized by low concentrations of serum T4, such as that resulting from iodine deficiency, type II iodothyronine 5'-deiodinase activity rises in the brain and liver, resulting in enhanced conversion of T4 to T3, and, thus partially compensating for the diminished serum (Leonard and Koehrle 1996). The interrelation of $\mathrm{T}_{4}$ and $\mathrm{T} 3$ in mediating the effects of THs has assumed particular importance in the case of brain development. The brain is especially rich in type D2 iodothyronine 5'-deiodinase (Leonard and Koehrle 1996). The demonstration that augmented type II 5'-deiodinase activity in brains of hypothyroid animals serves to preserve the level of intracellular $T_{3}$ strongly, suggests that the interaction of T3 with specific nuclear receptors is a critical step in mediating thyroid hormone action in the brain (Leonard and Koehrle 1996).

\subsection{Birds as Bioindicators of POPs}

\subsubsection{Introduction}

Considerable attention has been paid in recent years in understanding the transport, fate and distribution of the persistent organic pollutants (POPs) as they are found in wildlife all over the world including those from supposed pristine areas (e.g. Auman et all997; Muir et al 1999; Guruge et al 2001; Wyk et al 2001;

Kunisue et al 2002; Tanabe 2002; Verboven et al 2009). An elaborate review by Elliott and Harris (2001/2002), examining the consensus among scientists, that 
dichloro-diphenyldichloroethane (DDT) and other contaminants such as polychlorinated biphenyls (PCBs), polychlorinated dibenzo-p-dioxins (PCDDs), Polychlorinated dibenzofurans (PCDFs) and other organochlorines (OCs) pesticides have contributed to the reduced nest success and population decline in bald eagle populations, did help to focus precisely on the susceptibility of birds from a toxicological point of view. As it is evident to researchers in this field, these chemicals are ubiquitous and present virtually in all the wildlife tissues. As a result of this, a dramatic increase in public concern about the state of the POPs contaminations has occurred in recent years, in relation to growing evidence that POPs cause severe toxicological impacts on animals.

A solution to the problems posed by POPs on a global level must start from monitoring these substances in a wide range of ecosystems. In order to monitor POPs, their environmental consequences and to assess ecosystem health it is necessary to use effective bioindicator species, which accumulate POPs from corresponding areas. An elevated number of published information on pesticide residues in birds is available indicating serious reproductive impairment in some birds, many of which had become endangered species (e.g. black-backed gull, Larus fuscus) (Ove Bustnes et al 2006). Biologists studying declining populations of predaceous birds had found relationships between dichlorodiphenyldichloroethylene (DDE) in bird tissues and egg-shell diameter decrease, but no studies had determined the exact cellular and genetic 
mechanism of how DDE might be responsible for reproductive failure and population declines (Peakall and Kiff 1988).

Similar to marine mammals, fish-eating birds have been adversely affected by POPs contamination. The reduced capacity to detoxify (Tanabe 2002) and higher exposure via dietary intake enable some seabirds to accumulate high levels of PCBs (Walker et al 1984). Among the avian species (e.g. bald eagles, Haliaeetus leucocephalus), fish eating birds show serious teratogenic and reproductive dysfunctions because of high PCB accumulation (Tillitt et al 1992; Yamashita et al 1993) and most of the effects were generally associated with the dioxin-like planar PCBs (Guruge at al 2000).

Ratcliffe (1967) discovered that shells of raptor eggs from England weighed $18.9 \%$ less than they did before the dichlorodiphenyltrichloroethane (DDT) era began, which explained why the shells broke during incubation. Later, Hickey and Anderson (1968) found a direct inverse correlation between the DDE residues in eggs and the shell thickness in peregrines, bald eagles and osprey. However, Parslow and Jefferies (1977) demonstrated that for any particular bird species the amount of eggshell thinning is closely and linearly correlated with the DDE level in the egg and is not influenced by the levels of other pollutants such as dieldrin or PCBs (Furness et al, 1993). The authors also stated that once such a relationship is established one could use the very easily measured eggshell thickness of regularly sampled eggs to monitor the level of DDT pollution in a 
region. Some argued that DDE was not responsible for eggshell thinning and population decline in birds (Edwards 1972; Beatty 1973), but the positive response of birds to the ban on DDT in USA proved these criticisms wrong (Peakall, 1990). Beyer et al (1996) reviewed the problem assessments supported by residue analyses in birds, in their book Environmental Contaminants in Wildlife - Interpreting Tissue Concentrations. Contaminants that are identified include organochlorine insecticides, polychlorinated biphenyls, heavy metals, dioxins, etc. The conclusions reached in these studies provided a basic perspective on the occurrence and effects of pollutant contamination on wildlife.

Bans and restrictions imposed by several countries have reduced domestic contamination and the situations have improved in some domestic bird populations by reducing the exposure of resident wild birds and their prey. However, the problem existed in a different way, at least in the case of birds. The migratory species of both prey and predator birds often are exposed elsewhere during their travels (Ramesh et al 1992; Tanabe et al 1998; Muir et al 1999; Tanabe 2002; Kunisue et al 2003). Residue analysis again helped to define the nature and locations of migrant exposure. For example, Henney et al (1982) found that the peregrine falcons accumulate DDE in their bodies during their annual migration to Latin America. Migratory birds of the Arctic are the bestdocumented examples of such a contamination. Muir et al (1999) has stated that the birds of the Arctic, which breed in the north and over-winter in more temperate and industrialized latitudes, contain higher levels of OCs than the birds 
that over-winter in the north. Levels of contamination are taken up by feeding on the overwintering grounds and transported north each spring when the birds migrate back to their breeding grounds.

The seabird eggs have also been shown to be an efficient, conservative tool for monitoring OC levels in the marine environment (Gilbertson et al 1987; Oxynos et al 1993; Braune et al 2001). The authors compared the levels of various OCs like DDE, PCB, HCB, oxychlordane etc. in the eggs of different birds occurring at the Arctic Circle and found a declining trend in the concentrations of these chemicals from the mid-1970s to late 1980s. In fact, as stated earlier, the toxic effects by POPs on birds have been first detected in bird eggs (Moore and Ratcliffe 1962). Later Peakal (1974) extracted remnant lipids from museum eggs and showed that DDE was present in the peregrine eggs collected in 1948.

The contaminant residue studies in birds and bird eggs can help to define problems such as mortality, behavioral aberrations, eggshell thinning, reproductive failure and population decline in birds and also the resultant exposure of humans to these contaminants, because many of such birds make important food items to humans. This may raise toxicological concerns for both wildlife and mankind, based on historical and ongoing trends in the use of organochlorines. In this aspect the necessity of continual monitoring and surveillance of these substances in birds is recognized. 
Unlike in the case of developed countries (e.g. Pain et al 1999; Guruge et al 2000; Guruge et al 2001; Sakamoto et al 2002; Helgason et al 2008; Verboven et al 2009; Elliot et al 2009) data on the pollutant loads from the developing countries of Asia, South America and Africa are very much limited (Goldstein et al 1996; Lacher et al 1997; Senthilkumar et al 1998; Tanabe et al 1998; Wyk et al 2001; Minh et al 2002; Kunisue et al 2003; Bouwman et al 2008) and hence collection of data on the resident and migratory birds from the developing nations has become mandatory. At the same time the possibility of the usage of bird species as bioindicators of POPs pollution in respective regions may be justified for several reasons such as their high mobility, easy susceptibility to pollutants, excretion via several routes, etc.

\subsubsection{Factors affecting POPs accumulation in birds}

The life of birds is regulated by opportunities for finding food and avoiding predators. They have to face drastically different conditions of life between summer and winter. Without much exception, all birds have at least a small range of migratory territory (Alerstam 1993). Avian species are useful bioindicators for monitoring $\mathrm{OC}$ contamination of the environment, because they are often at relatively high position in the food chain. The resident birds, which principally have localized feeding and breeding grounds throughout the year may reflect the background pollution of the inhabiting area through the levels of contamination in their bodies (Kunisue et al 2003). 
Henny and Blus (1986) reported that the individuals of black-crowned herons reproducing at Ruby Lake, Nevada contained different levels of pesticide residues depending upon the different wintering grounds they have visited. Springer et al (1984) also found that the contaminant profiles (relative amounts of different compounds) among populations of peregrine falcons helped to evaluate the origin of residues in falcons and did not reflect the levels in the ambient environment from where they were collected.

Minh et al (2002) and Kunisue et al (2003) in their work on the persistent organochlorine residues in resident and migratory birds from Asia found considerable variations in the levels of DDTs, PCBs, $\mathrm{HCH}$ (hexachlorocyclohexanes) isomers $(\mathrm{HCHs})$, chlordane compounds $(\mathrm{CHLs})$ and HCB (hexachlorobenzene) between the resident and migrant species collected from the same location. Kunisue et al (2003) predicted the predominant contaminants in India, Japan, the Philippines, Russia (Lake Baikal) and Vietnam; using residue levels data from resident birds. At the same time, the migrant birds from different countries had different patterns of $O C$ residues, reflecting that each species has inherent migratory routes and thus has exposure to different contaminants. Dauwe et al (2003) also cautioned while recommending Great tit (Parus minor) nestlings as biomonitors of $\mathrm{OC}$ pollution that the contamination on natal and breeding sites of the females are different which may cause differences in body burden among breeding females. Recently, Elliott et al (2009) reported that bald eagles (Haliaeetus leucocephalus) at pelagic marine sites in the pacific 
North American coast showed high-trophic level and marine input, while eagles at freshwater sites analyzed showed low-trophic levels; and eagles at the estuarine and inshore marine sites had intermediate values. The authors concluded that it was a relationship between trophic level and marine input that may reflect longer food chains in pelagic, compared to terrestrial ecosystems. Where the sum of PCBs and DDE concentrations generally increased with trophic level and marine input (with the exception of the freshwater sites), while PBDEs, hydroxylated-PBDEs and hydroxylated-PCBs increased with marine input, independently of their trophic level.

\subsubsection{Tissue Specific Accumulation in birds}

Several organs and tissues of birds and whole eggs are generally used for evaluating the contaminant burdens in birds and their environment. Kunisue et al (2003) used the breast muscle, liver and whole body homogenates of different birds collected from India, the Philippines, and Russia for analyzing the POPs like PCBs, DDTs, CHLs, HCB and also $\mathrm{HCH}$ and have normalized the values for lipid weight basis for interpretation of the data. Kallenborn et al (1998) analyzed the nine egg samples and three liver samples of Cinclus cinclus L. and found that the sum concentrations of the DDTs and PCBs in liver and egg samples cover more than $90 \%$ of the total pollutant burden. Moreover, the sum concentrations of the contaminants in eggs show higher average values than in liver samples. They also found different patterns of pollutants in egg and liver samples which were attributed to the differences in matrix composition, 
especially lipid content.

Olafsdottir et al (1998) while evaluating the seasonal fluctuations of organochlorine levels in the common eider (Somateria mollissima) in Iceland found varying levels with season in breast muscle and liver, which they have attributed to the shrinking fat in winter for energy requirements. Wyk et al (2001) selected liver, heart, kidney, pectoral muscle, whole blood and clotted blood from three species of vultures from different localities of South Africa purposefully for measuring $14 \mathrm{OCs}$ including $\mathrm{HCH}$, Chlordane, dieldrin, endosulfan and heptachlor epoxide, due to the fact that they represent major systems in the body. The authors have selected heart and blood because they perform the circulatory functions in the body, muscle represents the dominant body mass, liver is the chief site of metabolism, and kidney the site of excretion for these contaminants. These authors have observed statistically different concentration ranges among different tissues, whole blood, liver, kidney, heart and muscle for all the five toxicants. But these authors have reported all their values on a wet weight basis and have not reported the fat percentage of their samples. Normalizing the values on a fat weight basis might have abated these differences largely. In an elaborate work on Indian birds, Tanabe et al (1998) found malefemale differences of organochlorines on a whole body basis and related this to females excreting OCs via their eggs. 
Connell et al (2003) evaluated the DDTs, PCBs, HCHs and CHLs in the eggs of two Ardeid species, the little egret (Egretta gazetta) and the black-crowned night heron (Nycticorax nycticorax) from Hong Kong to determine the exposure associated risk parameter. The eggs can be easily collected without much detriment to the population. However, whole body burdens of the contaminants may give an accurate picture of the contamination levels, at least in the case of small birds. Commonly, for the larger birds, the breast muscle has been traditionally the most suitable sample, rather than the organs like liver and kidney, which have the function of metabolizing and detoxifying the contaminants. However, Griffin et al (2001) observed the changes in the plasma lipoprotein metabolism in chicks as response to exposure of PCBs; and Traag et al (2006) analyzed and compared the residues of polychlorinated dibenzo-pdioxins (PCDD/Fs) and PCBs in eggs, fat and livers of laying hens following a consumption of contaminated feed. The authors concluded that there was a confident relationship of using livers as suitable organ bioindicator of bioaccumulation of POPs.

\subsubsection{Using Birds as Bioindicators}

Marine birds are useful as bioindicators of environmental pollution in estuarine and marine environments because they are often at the top of the food chain, ubiquitous, and many are abundant and common, making collecting possible. Seabirds have the advantage of being large, wide-ranging, conspicuous, abundant, long-lived, and easily observed for people. Many avian species 
belongs to the top of the food chain, where they bioaccumulate contaminants trhough aging (Burger and Gochfeld 2004).

Enormous numbers of publications are available explaining the spatial and temporal distributions of POPs in birds, but most of them explain the differences in POPs due to migration patterns (Klemens et al, 2000; Minh et al, 2002; Kunisue et al, 2002: Letcher et al, 2009). Birds are, no doubt, good bioindicators of POPs. Birds have been used in almost every part of the world as bioindicators of pollution in the place where they reside as well as in their migratory routes.

In the Great Lakes Ecosystem in Canada, colonial fish-eating birds have been used as convenient sentinel biological systems for detection and monitoring of the effects of chronic exposure to complex mixtures of persistent toxic environmental contaminants (Fox 1993). Studies of impairments to health using such biomarkers as induction of mixed function oxidases, alterations in heme biosynthesis, retinol homeostasis, thyroid function and DNA integrity and various manifestations of reproductive and developmental toxicity in these birds suggests the severity varies with time and location and generally decreased between the early 1970 s and late 1980s. However, these studies confirm the continued presence of sufficient amounts of PCBs and related persistent halogenated aromatic hydrocarbons in forage fish to cause physiological impairments in these birds over much of the Great Lakes basin (Fox 1993). 
Tanabe et al (2003) evaluated the levels of PCDDs, PCDFs and coplanar PCBs in five albatross species from the North Pacific and Southern Ocean for assessing the north-south differences in residue levels. They found that the Black-footed and Laysan albatrosses from the North-Pacific contained higher levels of PCDDs/Fs and coplanar PCBs than the albatrosses from the Southern Ocean, indicating that emission sources of these contaminants were predominant in the northern hemisphere. Residue levels in albatrosses from the remote North Pacific Ocean far from the point source of pollution were comparable or higher than terrestrial and coastal birds from contaminated areas of developed nations, suggesting specific exposure and accumulation of OCDDs/Fs and coplanar PCBs in albatrosses. The authors found that the relative proportions of PCDFs and coplanar PCBs were higher than those observed in birds inhabiting terrestrial and coastal areas, suggesting that these toxic chemicals may have higher transportability than PCDDs, by air and water. Earlier to this, Auman et al (1997) noticed significant differences among sampling periods, in the total concentrations of PCBs, DDT and DDE in the plasma between Layson albatross and black-footed albatross collected from remote areas of the North Pacific. They have attributed this to the differences in the mobilization of fat reserves due to extended periods of egg incubation without feeding and foraging over great distances to obtain food for the chicks. Recent works on the spatial and temporal variations in the POPs in birds from the Asian countries are comparatively less when compared with the northern hemisphere countries. 
Recently, a extensive literature review was published by Letcher et al (2009), the review analyze recent studies on biological effects in relation to $\mathrm{OHC}$ exposure, and attempts to assess known tissue/body compartment concentration data in the context of possible threshold levels of effects to evaluate the risks. This review concentrates mainly on post-2002 studies, where new $\mathrm{OHC}$ effects data in Arctic wildlife and fish are published, where observable effects data for populations of several top trophic level species, including seabirds (e.g., glaucous gull (Larus hyperboreus)), polar bears (Ursus maritimus), polar (Arctic) fox \{Vulpes lagopus), and Arctic charr (Salvelinus alpinus), as well as semicaptive studies on sled dogs (Canis familiaris).

$\mathrm{OHC}$ contaminant exposures in Arctic wildlife and fish effects are largely based on correlations between biomarker endpoints (e.g., biochemical processes related to the immune and endocrine system, pathological changes in tissues and reproduction and development) and tissue residue levels of OHCs (e.g., PCBs, DDTs, CHLs, PBDEs and in a few cases perfluorinated carboxylic acids (PFCAs) and perfluorinated sulfonates (PFSAs)). Some exceptions include semifield studies on comparative contaminant effects of control and exposed cohorts of captive Greenland sled dogs, and performance studies mimicking environmentally relevant PCB concentrations in Arctic charr. 
However, the authors suggest that the true (if any real) effects of POPs in Arctic wildlife have to be put into the context of other environmental, ecological and physiological stressors (both anthropogenic and natural) that render an overall complex picture. For instance, seasonal changes in food intake and corresponding cycles of fattening and emaciation seen in Arctic animals can modify contaminant tissue distribution and toxicokinetics (contaminant deposition, metabolism and depuration). Also, other factors, including impact of climate change (seasonal ice and temperature changes, and connection to food web changes, nutrition, etc. in exposed biota), disease, species invasion and the connection to disease resistance will impact toxicant exposure. Overall, further research and better understanding of $\mathrm{POP} / \mathrm{OHC}$ impact on animal performance in Arctic biota are recommended (Letcher et al 2009).

\subsection{Endocrine Disrupting Compounds (EDCs) in Wildlife}

Endocrine disrupting compounds (EDCs) are chemicals that may interfere with the body's endocrine system with resulting adverse developmental, reproductive, neurological, and immune effects in both humans and wildlife (NRDC 2009).

Alterations in endocrine development at early stages (or during ontogeny) can have permanent and detrimental effects throughout the life of the organism. Studies of endocrine disruption by pollutant chemicals have focused mainly on alterations in reproductive development and function. For example, beluga whales from the St. Lawrence Seaway, where the waters are highly 
contaminated with OCs [e.g. PCBs], showed hermaphroditic qualities where some males had both male organs (epididymis, vas deferens, and testes) and female organs (uterus and ovaries) (Colborn et al 1996). Likewise, Everglades National Park and Big Cypress Swamp in Southern Florida lie downstream from large agriculture areas where pesticides are heavily used. Panthers that reside in this area show signs of sterility, decreased sperm count, and undescended testes (Crain et al 1997). In Lake Apopka in Florida, male alligators have abnormally small penises and defective testes, and females show follicle and ovary abnormalities. The hormone ratios in these male alligators are like those of a normal female and females had estrogen levels above normal (Guillette and Crain 1996). Such observations led to the hypothesis that chemical pollutants bind to hormone receptors for reproductive steroids and either trigger actions similar to those of the native hormone (hormone agonists) or prevent the native hormone from binding but do not trigger cellular action (hormone antagonists) (Gray 1992).

\subsubsection{EDCs in Birds}

Birds feeding at top of the food chain are exposed to high levels of pollutants due to bioaccumulation and biomagnification of pollutants with trophic level (hunting, opportunistic feeding, etc) (Burger and Gochfeld 2004).

Herring gulls have been an important/keystone study species for the Canadian Wildlife Service since the early 1970s. Specifically, their eggs have been used to measure residue levels of biotoxins as an indication of chemical contamination in 
wildlife of the Great Lakes basin (Mineau et al 1984; Hebert et al 1999). Herring gulls are the only species that are year-round residents on the Great Lakes system and therefore represent pollutants accumulated only from the Great Lakes ecosystem.

Braune et al (2007) published data of OCs pesticides; PCBs, total mercury and selenium that were measured in eggs of thick-billed murres, northern fulmars and black-legged kittiwakes collected from Prince Leopold Island in the Canadian High Arctic between 1975 and 2003. The primary organochlorines found were $£$ PCB, p,p'-DDE, oxychlordane, and hexachlorobenzene (HCB). Most of organochlorines analyzed showed either significant declines or no significant change between 1975 and 2003 in all three species. However, significant increases were observed by the authors for $£ \mathrm{HCH} j_{n}$ the kittiwakes and fulmars, and $\mathrm{B}-\mathrm{HCH}$ in the murres and fulmars.

The production and use of nonpolybrominated diphenyl ether (non-PBDE), brominated flame retardant (BFR) alternatives have been on the rise, although their assessment in environmental samples is largely understudied. Gauthier et al (2009) reported several non-PBDE BFRs were found in the egg pools of herring gulls (Larus argentatus) from seven colonies in the five Laurentian Great Lakes (collected in 1982 to 2006). Of the 19 BFRs monitored, hexabromobenzene (HBB), 1,2-bis(2,4,6-tribromophenoxy)ethane (BTBPE), decabromodiphenyl ethane (DBDPE), and a-, B-, y. and 5-isomers of 1,2- 
dibromo-4-(1,2-dibromoethyl)cyclohexane $(\mathrm{TBECH})$ were present in eggs from all the colonies with the highest detection frequencies of $100 \%, 54 \%, 9 \%$ and $97 \%$, respectively. The authors concluded that over the past 25 years non-PBDE BFRs have accumulated variably in female herring gulls and have been transferred during ovogenesis to their eggs, indicating that there has been continual exposure and bioaccumulation of several BFRs in the Great Lakes.

Liver concentrations of retinyl palmitate, the principal storage form of vitamin A, have improved in some locations, whereas the depletion of retinyl palmitate has worsened in others. Mild to moderate highly carboxylated porphyria is still a problem, as is the birds' reduced immune competency. Most of the improvements in bird conditions reported by Fox and co-workers occurred before 1985, reflecting the regulation mentioned above of some of the OCs. However, little improvement in bird health has occurred since 1985, which was confirmed with biochemical analyses where was measured dioxin toxic equivalent (TEQs) and monitoring for obvious deformities in chicks (Giesy et al 1994). The lesions frequently found in the chicks from the Great Lakes provide evidence that the problem is still the result of exposure to contaminants during organization prior to birth or hatching (Colborn 2002).

Alteration of endocrine functions mediated by EDC exposure may act through interference with the synthesis, secretion, transport, binding, action, or elimination of endogenous hormones (Damstra et al 2002). The major 
explanation evoked for the interaction between EDCs and Gulls from Northern Norway such as certain OHCs -for example, PCBs, PCDDs, DDTs, and hydroxylated metabolites of PCBs (OH-PCBs) and the endocrine system is the structural similarity of EDCs with endogenous hormones (Verreault et al 2004).

\subsubsection{Thyroid Hormones and Perfluorinated Compounds}

Poly-and perfluorinated organic compounds (PFCs) are a class of substances characterized by a partially or fully fluorinated alkyl chain and a terminal functional group. The C-F bonds result in great stability under extreme heat and chemical stress and give the compound an oleophobic (oil repelling) property, whereas the polar head contributes to the excellent surfactant property of many PFC (e.g., perfluorinated sulfonates and carboxylates). These unique properties contribute to the widespread use of PFCs in a variety of commercial products, such as household surface finishes, food packaging, water- and stain-resistant materials, fire-fighting foams, etc (Kissa 2001).

The toxicology of PFCs has recently been extensively reviewed (Kudo and Kawashima 2003; Lau et al 2008). Among other observations, decreased $\mathrm{TH}$ levels after PFC exposure have been found in monkeys and rodents (Luebker et al 2002; Seacat et al 2003; Thibodeaux et al 2003). It has recently been shown that Perfluorooctane Sulfonate (PFOS) compounds does not affect the regulatory functions of the TH system itself, but its competitive binding to transport proteins alters the free thyroxine (T4) levels in blood (Chang et al 2008; Lau et al 2007). 
Recently a study by Weiss et al (2009) concluded that the decreased levels of free T4 found in the presence of PFCs in serum and of the bioaccumulation of PFCs in humans and wildlife that may be partly attributed to the affinity of PFCs to bind to TTR in serum. No data related to PFCs effects on avian thyroid hormones or in hormone transport proteins was found.

\subsubsection{Organohalogenated compounds and Avian Thyroid Hormones}

In the Great Lakes, PCBs are abundant and widespread contaminants and are found in the tissues of fish-eating birds (Fox et al 1993). Until their banning in 1979, PCBs were largely used as fire retardant fluids in capacitors, coolant fluids in transformers, and as wetting agents and surfactants. Due to their long half-life and lipophilic properties, PCBs are incorporated into organisms low in the food chain and are biomagnified; that is, they increase in concentration with each increase in the food chain. Given their high position on the food web, fish-eating (piscivorous) birds, such as herring gulls, potentially are exposed to PCB biomagnification and have been used as sentinel species to monitor the concentrations and biological effects of environmental contaminants in the Great Lakes (Ness et al 1993).

The coplanar PCB congeners are dioxin-like and their toxicity appears to be mediated mainly through the aryl hydrocarbon receptor (AhR). Dioxin-like toxicity is estimated by using 2,3,7,8-tetrachlorodibenzo-p-dioxin (TCDD) potency as the standard, either as toxic equivalency factor (TEF) for individual compounds or as 
the TCDD toxic equivalent for mixtures (Safe 1990). The non-planar congeners do not bind to the AhR but are found in high concentrations in the tissues of wild animals (Nessel et al 1992). To date, most of the reports of thyroid disruption in birds have been on wild birds exposed to mixtures of pollutants (Fox 1993; Grasman et al 1996; Murk et al 1994; Van den Berg et al 1994). Since the early 1990s, thyroid alterations in laboratory rodents have been associated with treatments of several specific congeners, both coplanar (e.g. PCB-169, 126, 156, 77) (Grasman et al 1996; Murk et al 1994) and non-coplanar (e.g. PCB-13, 52, 153) (Van der Kolk et al 1992; Morse et al 1993; Van Birgelen et al 1992) and with PCB mixtures (e.g. Arochlor 1254; Bastomsky, 1974; Morse et al 1996).

There are numerous reports of PCBs decreasing plasma $T_{4}$ levels in mammals (Byrne et al 1987; van den Berg et al 1988; Ness et al 1993; Li et al 1994) and birds (Van den Berg et al 1994). Significant negative associations between blood levels of a selection of OCs and circulating $\mathrm{THs}$ and $\mathrm{TH}$ ratios in plasma of male glaucous gulls breeding at Bear Island in the Barents Sea had been documented (Verreault et al 2004). Consequently, It is known that PCBs cause detectable alterations in plasma T4 and/or T3 levels; however, no data about the quantification of the binding affinity of the most relevant compounds (environmental relevant concentrations) was found in the literature for birds.

To date, there is less known about the effects of PCBs on thyroid function in birds than in laboratory mammals or fish. Even so, many developmental and 
physiological abnormalities in birds exposed to pollutants are suggestive of thyroid alterations. Most goiters (thyroid gland enlargement) are a compensatory response of the thyroid gland to stimulation by TSH. Thyroid gland enlargement (goiter) and epithelial hyperplasia has been observed and documented since the 70s in herring gulls from polluted Great Lakes sites (Fox et al 1993; Moccia et al 1986) and in PCB-dosed lesser black-backed gulls and guillemots (Jefferies and Parslows 1972). Homing pigeons fed DDT, DDE, dieldrin, and PCBs show signs of goiter and alterations in thyroid histology (Jefferies and French 1972). Lower incubation attentiveness, resulting from nervous system dysfunction, could be due to deficient thyroid hormone supply to the CNS. Wild birds exposed to pollutants [Forster's terns from Green Bay and herring gulls from Lake Ontario (Fox et al 1978)] have lower incubation attentiveness. Likewise, in laboratory studies on ring doves fed PCBs (Peakall and Peakall 1973), and in ring doves dosed with a PCB-organochlorine mixtures (McArthur et al 1983) incubation attentiveness was altered.

THs are also necessary for maintenance of normal metabolic function. Alterations in metabolic rate and oxygen consumption have been observed in PCB-fed morning doves (Mayer and Tori 1981) and pigeons fed dieldrin and DDE (Jefferies and French 1971). More recent studies of laboratory and wildcaught birds have measured thyroid-related variables to access possible thyroid alterations from PCB exposure. In 28-day old Eider ducklings injected with PCB77 (3,3',4,4'-tetrachlorobiphenyl, a coplanar dioxin-like congener) plasma Total 
$\mathrm{T}_{4}$ and Total T3 concentrations decreased (Murk et al, 1994). Van den Berg (1994) found significant reductions in plasma thyroid hormones in cormorants at 1 of 2 polluted sites studied in the Netherlands. However, though plasma $\mathrm{TT}_{4}$, FT4 and TT3 levels were reduced, only FT4 concentrations were significantly correlated with site PCB concentrations. Surprisingly, in breeding doves fed PCB mixtures, there was a significant increase in circulating $T_{4}$ concentrations (McAuthur et al, 1983). Increases in the $T_{4}$ levels were correlated by Peakall and Peakall (1973) on PCB-dosed doves, with total wing-flipping and in-bowl activities of courtship pairs, suggesting a T4-induced hyperactivity.

In contrast, other studies on PCB exposed birds show no alterations in circulating thyroid hormones. In Japanese quail dosed with two mixed PCB preparations, there were no differences in plasma thyroid hormone concentrations despite signs of goiter development (Grassle and Biessmann 1982). Likewise, no changes were found in plasma thyroid hormone concentrations in 3-week old herring gulls injected with two doses of PCB-77 (Brouwer 1991). The herring gulls also showed no signs of thyroid hyperplasia. Some wild-caught birds from polluted sites also show no alterations in circulating thyroid hormones. In herring gull and Caspian tern chicks, plasma T4 levels did not differ in Great Lakes sites with different PCB concentrations (Grasman et al 1996). Murk et al (1994) also found no consistent pattern of a decrease in $\mathrm{TH}$ concentrations with an increase in PCB exposure in chicks of the common tern in coastal waters of the Netherlands and Belgium. From these studies, it is difficult to evaluate how PCBs 
affect directly the thyroid function in birds. In addition, the lack of obvious alterations in plasma $T_{4}$ concentrations in some birds exposed to PCBs suggests that these birds may be compensating for PCB effects by increasing TSH secretion.

Whereas in mammals, brown adipose tissue 5'D type II activity supplies T3 to the circulation even if circulating thyroid hormones concentrations are low, birds lack of BAT, so this source of T3 production is not available in avian systems. Leslie A. Fowler (2000) in her thesis provided experimental evidence that PCBs have direct effects on Brain 5'D type II activity in birds. In her study she examined the regulation of thyroid hormone supply during development in (1) domestic chicken embryos (Gallus domesticus) exposed to a specific dioxin like PCB congener (PCB-126) and (2) Herring gull (Larus argentatus) embryos and pre-fledglings from Great Like sites with different chemical exposures.

Brominated flame retardants (BFRs) comprise a diverse group of chemical classes, which are used or have been used in an array of commercial and industrial applications for the purpose of fire prevention. The occurrence of several classes of BFRs in the environment has become increasingly evident and presents a potential health risk to organisms exposed to these emerging classes of environmental contaminants (de Wit 2002; McDonald 2002). Several classes of BFRs, namely polybrominated biphenyls (PBBs), polybrominated diphenyl ethers (PBDEs), tetrabromobisphenol A (TBBPA), hexabromocyclododecane 
(HBCD), bis(2,4,6-tribromophenoxy)ethane (BTBPE), and tris(2,3dibromopropyl)phosphate (Tris), have been identified as environmental contaminants (Hakk and Letcher 2003). PBDEs, TBBPA, and HBCCD are of particular concern due to increasing environmental concentrations and their ubiquitous presence in the tissues of humans and wildlife from Europe, Japan, and North America. BFRs have been shown to be susceptible to several metabolic processes including oxidative debromination, reductive debromination, oxidative CYP enzyme-mediated biotransformation, and/or Phase II conjugation (glucuronidation and sulfation); however, substantially more research on metabolism is necessary to fully assess BFR fate, uptake and elimination kinetics, metabolic pathways, inter-species differences, the influence of congener structure, and the potential health risks to exposed organisms (Hakk and Letcher 2003).

Exposure of wild birds to PBDEs is of concern since these and other structurally similar chemicals (e.g., PCBs) alter blood thyroid hormone homeostasis (Darnerud et al 2001; McDonald 2002) and/or vitamin A stores (Hallgren et al 2001; Rolland 2000). Changes in these parameters may alter development, immunocompetence, reproductive success, and other physiological processes in birds. The mechanism by which PBDE exposure alters thyroid dynamics remains poor studied, but PBDEs are structurally similar to T4 with an halogenated diphenyl / ether backbone structure. 
TTR is a plasma protein necessary for the transportation of THs, besides the distribution of THs also transport vitamin $A$. In birds $T_{4}$ is known to have low binding affinity for TTR (Chang et al, 1999) with a short half-life (Astier 1980), which may render them susceptible to organohalogen induce alterations in circulating thyroid hormone concentrations. Studies with laboratory rodents have indicated that some PBDE congeners affect thyroid hormone transport and metabolism (Zhou et al 2001; 2002) as well as vitamin A levels (Hallgren et al, 2001).

More studies are necessary to address the extent to which adaptive thyroid responses may compensate for the effects of organohalogen phenolic mixtures and specific congeners, and the exposure time and concentration of congeners that elicit a thyroid specific biological response. Experiments are needed to be conducted both on field-caught birds and in laboratory assays to understand how environmental relevant organohalogen phenolic compounds may be affecting the TH transportation and delivered to target tissues. Fundamental differences in thyroid function between birds and mammals include: differences in the proportions of T4 and T3 in circulation, affinity of the TH transport proteins, and the lack of BAT in birds. Studies are needed to determine if the EDC effects on birds are comparable to what has been found in mammals. 
14.4 Metabolites from OHCs effects in avian thyroid hormone system

The THs $\mathrm{T}_{4}$ and $\mathrm{T} 3$ are phylogenetically conserved molecules that affect many aspects of development, growth and metabolism of vertebrates (Edeline et al 2005). THs have multiple effects on metabolism and development, in homoeothermic animals; they regulate basal metabolic rates and are essential for the maintenance of high and constant body temperature. The effect of THs on protein and lipid metabolism is of a biphasic nature: in low physiological concentrations, they are anabolic while at higher concentrations they are catabolic. During development, THs stimulate both growth and differentiation (or maturation). Their action can be direct, indirect or permissive. Most of the actions of THs seem to be dependent on the binding to a nuclear thyroid hormone receptor (TR). Two major isoforms of these receptors are known (TRa and TRB) and both of them preferentially bind T3. The main secretory product of the thyroid gland, the T4 was considered to be a relatively inactive prohormone due to its low binding affinity to TRs. Consequently, the peripheral metabolism of T4 by activating and inactivating pathways is very important in the regulation of the availability of receptor-active T3 and hence of thyroid activity (Decuypere et al 2005).

Several persistent OHCs, among these PBDEs, PCBs and chlorinated paraffins (CPs), have been shown to alter THs levels in experimental animals (Brower et al 1998; Brouwer et al 2001; Collins et al 1980a; Collins et al 1980b; Fowles et al 1994; Hallgreen et al 2001; Wyatt et al 1993). Effects on the thyroid hormonal 
system are important to study since THs play an essential role in the development of many organs, e.g. the brain (Dussault and Ruel 1987). Alterations in CNS development, observed or indicated in several species after OHC exposure (Tilson et al 1990), have thus been suggested a result of exposure to T4-modulating chemicals.

The mechanisms involved in the OHC-mediated alteration of plasma THs have been extensively investigated but are still not fully known. Firstly, enzymatic effects where described that could interfere with T4 levels. Bastomsky et al (1974) showed that increased biliary clearance of T4 was associated with an increase in hepatic $\mathrm{T}_{4}$ glucuronidation due to induction of uridine diphosphoglucuronosyl transferase (UDPGT). McCleary et al (2000) studied the disruption of the UDPGT activity in PCB-treated chicken embryos, and Quinn et al (2002) found that the polychlorinated biphenyl Aroclor 1242 can disrupt T4, estradiol, and consequently the plumage characteristics in the American kestrel (Falco sparverius). But, also enzymatic sulphation of THs are reported to be affected by PCB metabolites (Schuur et al 1998).

Secondly, there is morphological evidence for effects of OHCs on thyroid follicles (e.g. Collins et al 1980a; Collins et al 1980a; Saeed and Hansen 1997). These morphological effects, such as follicle epithelial cell hyperplasia, hypertrophy and decreased follicular colloid area, have been correlated with decreased serum levels of T4 and have also been suggested to include disturbances of enzymes directly involved in TH synthesis and release. As a third possible mechanism, 
hydroxylated metabolites of OHCs have been found to compete with $\mathrm{TH}$ transport proteins for binding THs, but mainly the major $\mathrm{T}_{4}$ in rats, resulting in a decreased plasma $T_{4}$ level (Brouwer et al 2001; Saeed et al 1997). The latter mechanism is dependent on the extent of metabolic conversion as phenolic metabolites of several groups of OHCs have higher affinity to TTR than have their unmetabolised counterparts. A characteristic effect of several OHCs is their potent induction of hepatic detoxification enzymes, i.e. cytochrome P450 (CYP450), and significant induction of 7-ethoxyresorufin-O-deethylase EROD activity during an immunochemically measured CYPIA protein (Eggensl et al 1996).

Attention to analyze metabolites from chlorinated and brominated POPs (hydroxylated-OH- and methoxy-MeO-) has been increasing in the past years. Recently, Kunisue and Tanabe (2009) analyzed plasma of different animals, including black-tailed gull (Larus crassirostris), common cormorant (Phalacrocorax carbo), and jungle crow (Corvus macrorhynchos). The authors detected eighteen known and fifty unknown peaks of OH-PCBs where the major congeners were 4'-OH-CB101/120, 4-OH-CB107/4'-OH-CB108, 4-OH-CB146, 4OH-CB178, 4-OH-CB187, 4'-OH-CB172, 4-OH-CB202, and 4'-OH-CB199. This biomonitor comparison study showed relatively higher concentrations of $\mathrm{OH}$ PCBs in animal species compared to humans. The authors reported that the $\mathrm{OH}$ PCB levels in black-tailed gull and common cormorant blood were one order of magnitude higher than in humans. In addition, they observe that penta-to hepta- 
chlorinated $\mathrm{OH}-\mathrm{PCB}$ congeners were predominant in human blood, but profiles of $\mathrm{OH}-\mathrm{PCBs}$ in other animals widely varied by species and taxa. Also, apparent metabolites of PBDEs such as hydroxylated PBDEs (OH-PBDEs), have been shown to have competitive binding affinity relative to $T_{4}$ with human transthyretin (TTR) (Hakk and Letcher 2003; Meerts et al 2000).

\subsection{Selection of Avian Models}

For this study, two birds were selected from two different diets and with exposure to different environments. Herring gulls (Larus argentatus) were selected to represent inland freshwater systems like Lake Ontario in Canada and glaucous gulls (Larus Hyperboreus) were selected to represent a Marine ecosystem from Svalbard Norway. These two species of sea birds are used as comparative bird models to observe the similarities and/or differences in the aminoacid composition of their TH transport proteins. Then, the identification of their binding affinities values to THs with and without presence of complex chemical mixtures from organohalogens and perfluorinated origins, found in circulating plasma of both species.

\subsubsection{Herring gulls in the Great Lakes}

The Great Lakes are the world's largest expanse of fresh water; they are Lakes Superior, Huron, Michigan, Erie, and Ontario. They cover over 249,000 km² $\left(96,500 \mathrm{mi}^{2}\right)$ and form a natural boundary between the Unites States and 
Canada. Lake Ontario is the last of the chain of Great Lakes that straddle the Canadian-U.S. border; New York State borders its shoreline on then south and Ontario on the north. Ontario is the smallest of the Great Lakes, with a surface area of $18,960 \mathrm{~km}^{2}\left(7,340 \mathrm{mi}^{2}\right)$, but it has the highest ratio of watershed area to

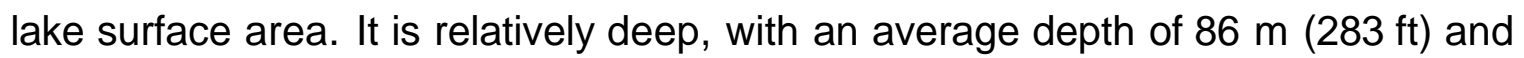
a maximum depth of $244 \mathrm{~m}(802 \mathrm{ft})$, second only to Lake Superior. More than $80 \%$ of surface water inputs to Lake Ontario originate from upstream Great Lakes and connecting waters. Lake Ontario discharges to the St. Lawrence River (Nat Aud Soc 2005; Env Canada 2005). The most common birds of the Great Lakes are the herring gull and the ring-billed gull. The common and Caspian tern are regular visitors in spring and summer, when they breed on the hundreds of small islands. In Canada, most seagulls are herring gulls; the adults are about $61 \mathrm{~cm}$ long from the tip of its bill to the tip of its tail. Its head, body, and tail are white, its bill is yellow with a red spot on the lower tip, and its legs are pink or flesh-colored (Nat Aud Soc 2005; Campbell et al 1990; Gauthier et al 1996).

Herring Gulls regurgitate, or bring up, food remains that they cannot digest, analyses of these pellets and of their feces show that Herring Gulls, like most other gull species, will eat almost anything; from clams, small fish, floating dead animals, small young and adults of other nesting birds, bread, and so on (Godfrey 1986). They have a knack for finding places where food is abundant, such as fish wharves and garbage dumps. Diet studies in the Great Lakes area showed that most pellets in colonies near large urban centers contained remains of garbage as well as various fish species. Pellets in colonies near agricultural 
areas often had the remains of small mammals, notably deer mice (Ryckman et al 1997). Herring Gulls are one of the most widespread species in Canada. Indeed, its breeding range includes every province and territory in Canada. Exceptions to their breeding range include the Pacific and Atlantic coasts, the southern United States, the coast of the Gulf of Mexico, and a few Caribbean islands. In the lower Great Lakes area, the species can be found year-round. Of the 43 species of gull found in the world, 16 have bred in Canada, but three have nested only occasionally. Specialized feeding techniques and different ranges prevent, or at least reduce, competition between species (Pierotti and Good 1994).

Herring Gulls are very social birds and prefer to nest in colonies. Once a colony is well established, they are faithful to it and reluctant to settle elsewhere. In the lower Great Lakes area, for example, older, experienced breeding birds usually stay close to their colonies and are the first to reoccupy nesting territories in early spring. Some may use the same nesting site for as long as 10 to 20 years (Pierotti and Good 1994). The year-round residence of this avian model is one of the most interesting characteristics that make herring gulls (Figure 4) a valuable bioindicator of the contamination in Lake Ontario. During this study, bird samples from liver and plasma tissues were obtained from two sites inside Lake Ontario, Canada (Figure 5) .The distribution of possible organohalogen compounds and their metabolites retained in the liver and plasma tissues of Herring gulls (Larus 
argentatus) from (two different colonies at) Lake Ontario, Canada, will provide data to compare the contaminant exposure with other gull studies.

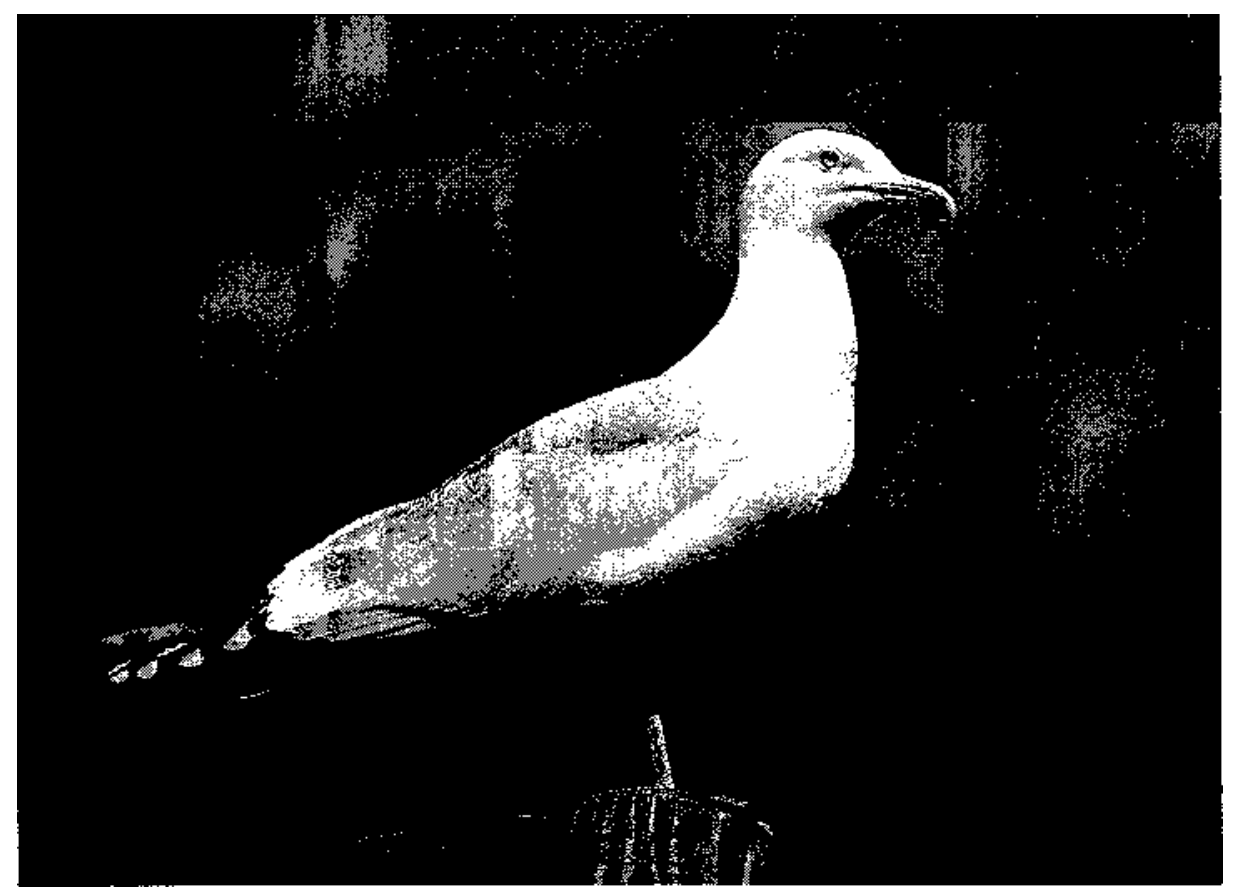

Figure 4. Herring gull, Larus argentatus (www.wikipedia.org). 
W. r?a..
$-\mathrm{TO}$

CANADA
$-? \mathrm{z}$.

........

^ /,

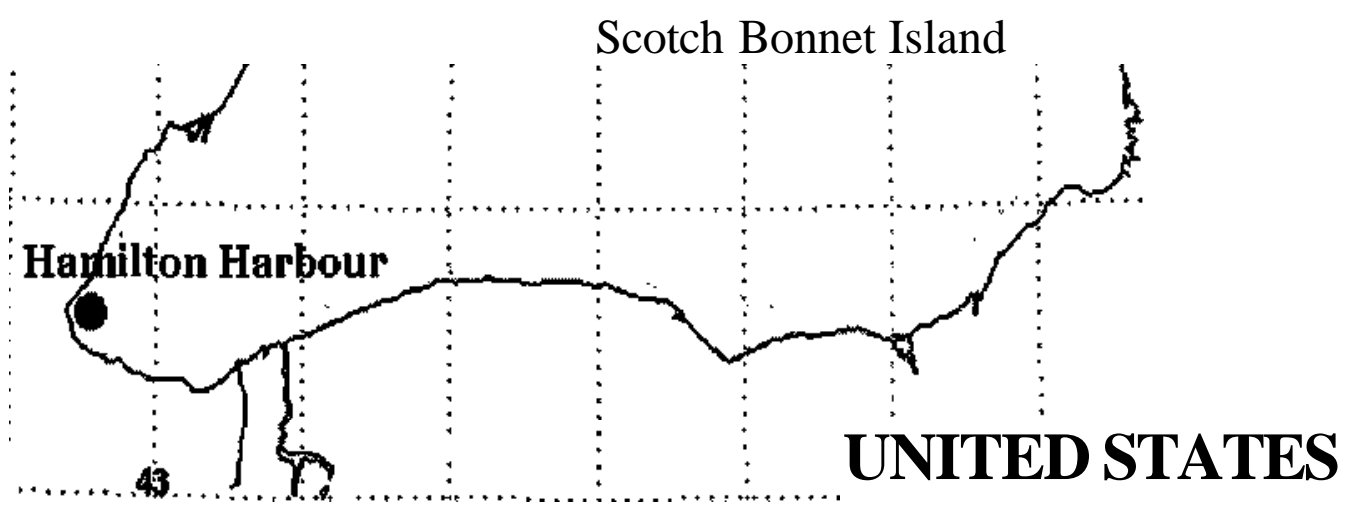

Figure 5. Map of Lake Ontario in Canada and the localization of the two colonies used in this study, Hamilton Harbour and Scotch Bonnet Island. 


\subsubsection{Glaucous Gull from Svalbard Island, Norway}

The Svalbard area is a key site for seabirds. The total breeding population of glaucous gull (Larus hyperboreus) on Svalbard has roughly been estimated to 1000 - 10,000 pairs (Boon et al, 1992). In the Svalbard area a considerable number of dead glaucous gulls, with high levels of PCBs have been found (Bruhn et al, 1995). No cause of death has been found, but it was indicated that the contamination levels might be an important problem lowering survival and possibly also reproduction in some areas (Gabrielsen et al, 1995). The glaucous gull is the most important avian predator in the Arctic ecosystem and due to its high trophic levels; it is particularly vulnerable to contaminant exposure. The mobilization of body fat reserves during periods of food limitation may result in the release of accumulated lipophilic contaminants, and a temporary increase in blood contaminant levels (Isaksen and Bakken, 1995). The resulting acute exposure to high contaminant levels imposes a higher risk upon these animals than indicated from tissue concentrations. This gives rise to concern because many contaminants may have a detrimental effect on the health and reproductive performance of animals. Glaucous gulls are omnivores like most Larus gulls, and they will scavenge as well as seek suitable small prey. These birds forage while swimming or walking, and also may pick up items off water or catch small birds while flying. They often follow fishing boats. The activity of glaucous gulls is therefore necessary to evaluate the total metabolic capacities of this species, and 
to acquire a better understanding of the fate and potential toxicity of environmental pollutants in Arctic seabirds.

\subsection{Thesis Objectives}

\subsubsection{Project summaries}

There is increasing evidence that chlorinated and brominated aromatic contaminants, such as polychlorinated diphenyl ethers (PBDEs) and the hydroxylated $(\mathrm{OH})$ metabolites (e.g., $\mathrm{OH}-\mathrm{PCBs}$ and $\mathrm{OH}-\mathrm{PBDEs}$ ) can interfere with the thyroid hormone system in, e.g. rats, humans and seals. For example, decreased serum levels of thyroxine $\left(T_{4}\right)$ have been correlated with exposure to PCBs and PBDEs both in humans and in rats. THs are lipid soluble and this solubility allows for permeation into membranes. However, the distributions of THs, which are generally hydrophobic, require certain proteins to increase their hydrophilicity.

Therefore, higher evolved vertebrates as mammals and birds possess a number of T4 transport proteins to serve this function. In mammals and birds three T4 transport (carrier) proteins are known to be synthesized in the liver i.e., thyroxinebinding Prealbumin (or transthyretin TTR), thyroxine binding globulin (TBG) and albumin. In avian species, albumin and TTR serve as thyroid hormone carrier proteins. 
Selected OH-PCB and OH-PBDE congeners (and other halogenated phenolics) have shown to competitively interact with human TTR. There is a lack of information about halogenated contaminants in thyroid hormones in avian species, specifically in the modulation of $\mathrm{TH}$ binding to hormone transporter proteins in birds (Albumin and TTR).

Main Goal: to assess the comparative effects of selected halogenated (phenolic) contaminants and analogues, as well as complex, natural mixtures, on the key thyroid system process of $\mathrm{TH}$ transpost, in two differentially exposed avian model species from marine and freshwater ecosystems. This Doctoral research will address four specific aims to test the following hypotheses.

\subsubsection{Specific Aims:}

1. The first aim is to investigate the distribution of possible organohalogen compounds and their metabolites retained in the liver and plasma tissues of Herring gulls (Larus argentatus) from two different colonies at Lake Ontario, Canada. It is possible that the two colonies present differences in their distribution and concentration of contaminants. The objective in this aim is to describe the possible differences between two organohalogen complex mixtures (neutral and phenolic extractions) through in-vitro observation and to provide the qualitative and quantitative analysis of the contaminants presents in the mixtures. These complex chemical extract mixtures will have a preliminary environmental approach to assess the 
thyroidogenic effects of known circulating levels of organohalogen and perflurinated compounds in plasma of herring gulls. And, the effect the possible disruption of binding affinity between $\mathrm{THs}$ and $\mathrm{TH}$ transport proteins in gulls. The results will be compared with human $\mathrm{TH}$ transport proteins.

2. The second aim is to contribute to the knowledge on thyroidogenic activity and compare the effects of selected halogenated (phenolic) contaminants and endocrine on key thyroidogenic process in avian model species using TH transport protein TTR from glaucous gull (Larus hyperboreus) and herring gull. Both species as representative top predators from a seawater ecosystem (Svalbard, Norway) and a freshwater ecosystem (Lake Ontario, Canada), then the finding will be compared with human. It is possible that differences exist in the amino acid composition of TTR between the two gull species examined and with humans. Then, the determination of affinity of TTR with and without presence of thyroidogenic OHCs will be addressed.

3. Since hormone transport proteins are highly likely to be disrupted by organohalogen-metabolite compounds, principally by hydroxyl and methoxy-PCBs / PBDEs, my third aim is based in the hypothesis that the thyroidogenic process in an avian model species are disrupted by chemical-contaminant competition with $\mathrm{TH}$ transport protein albumin of herring gulls. The use of a preliminary competitive binding assay using complex chemical mixtures isolated from plasma can guide us to further 
experiments and the selection of congeners with higher affinity for displacing TH transport proteins from binding THs. Through this.aim it is possible to assess the differences using cloned, expressed and purified herring gull albumin (ALB) with a selected set of environmental relevant contaminants (PCBs and PBDEs), for the possibility of disruption, and then comparing the affinity values with human albumin to observe possible differences among taxa.

4. In this aim, TTR and albumin from gulls previously cloned, expressed and purified (and commercially available human TTR and ALB) will be used to examine the competitive binding interactions of selected PFCs and PFC complex mixtures (neutral and acidic extractions) isolated from the livers of Lake Ontario herring gulls as a novel approach to a possible disruption of PFCs in thyroidogenic processes. In this aim, I will examine also the differences or/and similarities of PFCs concentrations in livers from two avian colonies inhabiting Lake Ontario. 


\subsection{References}

Adams et al, 2000. The genome sequence of Drosophila melanogaster. Science 287:2185-2195

Alerstam T, 1993. Bird Migration. Cambridge University Press, Cambridge, USA, p. 420.

Andersen M, Lie E, Derocher AE, Belikov SE, Bemhoft A, Boltunov AN, et al. 2001. Geographic variations of PCB congeners in polar bears (Ursus maritimus) from Svalbard east to the Chukchi Sea. Polar Biol 24:231-238.

Astier $\mathrm{H}$, 1980. Thyroid gland in birds: structure and function. In: Avian Endocrinology (Epple A, Stetson M, eds). New York:Academic Press, 167-189.

Auman, HJ, Ludwig JP, Summer CL, Verburugge DA, Froese KL, Colborn T, Giesey JP, 1997. PCBs, DDE. DDT and TCDD-EQ in two species of albatross on sand island, Midway atoll, North Pacific Ocean. Environ. Toxicol. Chem., 16 : 498-504.

Aurigi S, Focardi S, Hulea D, Renzoni D, 2000. Organochlorine contamination in bird's eggs from the Danube delta. Environ. Pollut., $109: 61-67$.

Ballschmiter K, Zell M, 1980. Analysis of polychlorinated biphenyls (PCBs) by glass capillary gas chromatography. Fresenius Z Anal Chem 302:20-31.

Barter RA, Klassen CD, 1994. Reduction of thyroid hormone levels and alteration of thyroid function by four representative UDP-Glucuronoyltransferase inducers in rats. Toxicol, and Appl. Pharmacol. 128, 9-17.

Bastomsky $\mathrm{CH}, 1974$. Effect of a polychlorinated biphenyl mixture (Aroclor 1254) and DDT on biliary thyroxine excretion in rats. Endocrinology 95: 1150-1155.

Beatty BG, 1973. The DDT myth. John day, New York, p. 201.

Berger U, Herzke D, Sandanger TM, 2004. Two trace analytical methods for determination of hydroxylated PCBs and other halogenated phenolic compounds in eggs from Norwegian birds of prey. Anal Chem. 76(2): 441-52.

Bernhoft A, Skaare JU, Wiig 0, 1997. Organochlorines in polar bears (Ursus maritimus) at Svalbard. Environ Pollut 95:159-175.

Beyer W, Heinz GH, Redmon-Norwood AW, 1996. Environmental Contaminants in Wildlife. A Special Publication of SETAC. CWC Lewis Publishers, Boca Raton, New York, London, Tokyo, p. 494. 
Bianco AC, Kim BW, 2006. Deiodinases: implications of the local control of thyroid hormone action. J Clin Invest 116(10): 2571-2579.

Boon JP, van Arnhem E, Jansen S, Kannan N, Petrick G, Schulz D, Duinker JC, Reijnders PJH, Goksoyr A, 1992. The toxicokinetics of PCBs in marine mammals with special reference to possible interactions of individual congeners with the cytochrome P450-dependent monooxygenase system: an overview. In Persistent pollutants in marine ecosystems, Eds. C. H. Walker and D. R. Livingstone. Pergamon Press, Oxford, pp. 119-60.

Borga K, Gabrielsen GW, Skaare JU, 2001. Biomagnification of organochlorines along a Barents Sea food chain. Environm Pollution, 113(2):187-198.

Bosveld ATC, van den Berg M, 2002. Reproductive failure and endocrine disruption by organohalogens in fish-eating birds. Toxicology, 181-182:155-159.

Bowen R. 2009. Chemistry of Thyroid Hormones. Hypertxts for biomedical Sciences. Colorado State University, www.vivo.colostate.edu (accessed on September 21, 2009).

Bowerman WW, Giesy JP, Best DA \& Kramer VJ, 1995. A Review of Factors Affecting Productivity of Bald Eagles in the Great Lakes Region: Implications for Recovery. Env. Health Perspec. 103: 51-59.

Bouwman H, Polder A, Venter B, Skaare JU. 2008. Organochlorine contaminants in cormorant, darter, egret, and ibis eggs from South Africa. Chemosphere, 71(2): 227-241.

Braune BM, Norstrom RJ, 1989. Dynamics of organochlorine compounds in herring gulls : III. Tissue distribution and bioaccumulation in Lake Ontario gulls. Env. Toxicol. Chem., 8 : 957-968.

Braune BM, Donaldson GM, Hobson KA, 2001. Contaminant residues in seabird eggs from the Canadian Arctic. Part I. Temporal trends 1975-1998. Environ. Pollut 114: 39-54.

Braune BM, 2007. Temporal trends of organochlorines and mercury in seabird eggs from the Canadian Arctic, 1975-2003. Environm Pollut 148: 599-613.

Brouwer A, Van den Berg KJ, 1986. Binding of a metabolite of 3,4,3',4'tetrachlorobiphenyl to transthyretin reduces serum Vitamin A transport by inhibiting the formation of the protein complex carrying both retinol and thyroxin. Toxicol. And Appl. Pharmacol. 85: 301-312. 
Brouwer A, 1991. Role of biotransformation in PCB-induced alterations in vitaminA and thyroid hormone metabolism in laboratory and wildlife species. Biochem. Soc. Trans. 13: 731-737.

Brouwer A, Morse DC, Lans MC, Schuur AG, Murk AJ, Klasson-Wehler E, Bergman A, Visser TJ, 1998. Interaction of persistent environmental organohalogens with the thyroid hormone system: mechanisms and possible consequences for animal and human health. Toxicol Ind Health 14: 59-84.

Brouwer A., Meerts IATM, Bergman A, Besselink HT, 2001. Thyroidogenic, estrogenic and dioxin-like activity of polybrominated diphenyl ethers (PBDEs) in vitro. Abstract to the Second Int. Workshop on Brominated Flame Retardants, Stockholm University, Sweden, 14-16 May, 2001.

Brucker-Davis F, 1998. Effects of environmental synthetic chemicals on thyroid function. Thyroid 8: 827-856.

Bruhn R, Kannan N, Petrick G, Schultz-Bull DE, Duinker JC, 1995. CB pattern in the harbour porpoise: Bioaccumulation, metabolism and evidence for cytochrome P450IIB activity. Chemosphere, 31: 3721-3732.

Burger J, Gochfeld M, 2004. Marine Birds as Sentinels of Environmental Pollution. EcoHealth 1: 263-274.

Byrne JJ, Carbone JP, Hanson EA, 1987. Hypothyroidism and abnormalities in the kinetics of thyroid hormone metabolism in rats treated chronically with polychlorinated biphenyl and polybrominated biphenyl. Endocrinology 121: 520527.

Campbell RW, Dawe NK. McTaggart-Cowan I, Cooper JM, Kaiser GW, McNall MCE, 1990. The birds of British Columbia. Volume II. Royal British Columbia Museum, Victoria.

Campbell RK, Satoh N, Degnan BM, 2004. Piecing together evolution of the vertebrate endocrine system. TRENDS in Genetics 20(8): 359-366.

Chang L, Munro SLA, Richardson SJ, Schreiber G, 1999. Evolution of thyroid hormone binding by transthyretins in birds and mammals. Eur. J. Biochem. 259: 534-542.

Chang SC, Thibodeaux JR, Eastvold ML, Ehresman DJ, Bjork JA, Froehlich JW, Lau C, Singh RJ, Wallace KB, Butenhoff JL, 2008. Thyroid hormone status and pituitary function in adult rats given oral doses of perfluorooctane sulfonate (PFOS). Toxicology 243: 330-339. 
Cheek AO, Kow K, Chen J and McLachlan JA (1999) Potential mechanisms of thyroid disruption in humans: interaction of organochlorine compounds with thyroid receptor, transthyretin, and thyroid-binding globulin. Env. Health Perspec. 107:273-278.

Cheng Y, Prusoff WH, 1973. Relationship between the inhibition constant (Ki) and the concentration of an inhibitor that causes a $50 \%$ inhibition $\left(\mathrm{I}_{5} \mathrm{O}\right)$ of an enzymatic reaction, Biochemical Pharmacology, 22: 3099-3108.

Colborn T, Dumanoski D, Myers JP, 1996. Our Stolen Future. New York: Penguin Books pp 306.

Colborn T, 2002. Clues from Wildlife to Create an Assay for Thyroid System Disruption. Environmental Health Perspectives. 110(3): 363-367.

Collins WT, Capen CC, 1980b. Fine structural lesions and hormonal alterations in thyroid glands of perinatal rats exposed in utero and by milk to polychlorinated biphenyls. Am. J. Pathol. 99: 125-142.

Collins WT, Capen CC, 1980b. Ultrastructural and functional alterations of the rat thyroid gland produced by polychlorinated biphenyls compared with iodide excess and deficiency and thyrotropin and thyroxine administration. Virchows Arch. B. Cell Path. 33: 213-231.

Connell, DW, Fung CN, Minh TB, Tanabe S, Lam PKS, Wong BSF, Covaci MHW, Voorspoels A, de Boer S, 2003. Determination of brominated flame retardants, with emphasis on polybrominated diphenyl ethers (PBDEs) in environmental and human samples a review. Environ. Int. 29: 735-756.

Damstra T, Barlow S, Bergman A, Kavlock R, van der Kraak G, eds. 2002. Global assessment of the state-of-the-science of endocrine disruptors. Geneva:World Health Organization, International Programme on Chemical Safety.

Darnerud PO, Morse D, Klasson-Wehler E, Brouwer A, 1996. Binding of a 3,3'4,4'-tetrachlorobiphenyl (CB-77) metabolite to fetal transthyretin and effects on fetal thyroid hormone levels in mice. Toxicology 106: 105-116.

Darnerud, PO, Eriksen GS, Johannesson T, Larsen PB, Viluksela M, 2001. Polybrominated diphenyl ethers: occurrence, dietary exposure and toxicology. Environ. Health Perspect. 109: 49-68.

Dauwe TSG, Chu A, Covaci, Schepens P, Eens M, 2003. Great tit (Parus minor) nestlings as biomonitors of organochlorine pollution. Arch. Environ. Contam. Toxicol., 44 : 89-96. 
Davidson TF, Flack IH, Butler EJ, 1978. The binding of thyroxine and triiodothyronine to plasma proteins in the chicken at the physiological $\mathrm{pH}$. Res Vet Sci 25:280-283.

de Swart RL, Ross PS, Timmernan HH, Hjiman WC, de Ruiter EM, Liem AKD, Brouwer A, van Loyeren A, Reijnders PJH, Vos, JG, Osterhaus DME, 1995. Short term fasting does not aggravate immunosuppression in harbour seal (Phoca vitulina) with high body burdens of organochlorines. Chemosphere 31 : 4289-4306.

de Wit CA, 2002 An overview of brominated flame retardants in the environment. Chemosphere 46: 583-624.

Decuypere E, Van As P, Van der Geyten S, Darras V, 2005. Thyroid hormone availability and activity in avian species: A review Domestic Animal Endocrinology, Volume 29(1): 63-77.

Dietrich, S, Buthe A, Denker E, Hotker H, 1997. organochlorines in eggs and food organisms of avocets (Recurvirostra avosetta). Bull. Environ. Contam. Toxicol., 58:219-226.

Dussault JH, Ruel J, 1987. Thyroid hormones and brain development. Ann. Rev. Physiol. 49: 321-334.

Duursma EK, Nieuwenhuize J, van Liere J, Hillebrand MTHJ, 1989. Partitioning of organochlorines between water, particulate matter and some organisms in estuarine and marine ecosystems of The Netherlands. Neth. J. Sea Res 20: 239251.

EBO, 2009. Encyclopedia Britannica Online, 2009. Endocrine system. In: Encyclopaedia Britannica. Retrieved October 27, 2009, from http://www.britannica.com/EBchecked/topic/186879/endocrine-system

Edeline ET, Bardonnet A, Bolliet V, Dufour S, Elie P, 2005. Endocrine control of Anguilla anguilla glass eel dispersal: Effect of thyroid hormones on locomotor activity and rheotactic behaviour. Hormones and Behavior 48: 53- 63.

Edwards JC, 1972. Cracking the thin shell myth. Agric. Chem. Commer. Fert. 27 :20-26.

Eggensl ML, Vethaak AD, Leaverz MJ, Horbach GJMJ, Boon JP, Seinen W, 1996. Differences in cypia response between flounder (Platichthys flesus) and plaice (Pleuronectes platessa) after long-term exposure to harbour dredged spoil in a mesocosm study. Chemosphere 32(7): 1357-1380. 
Elliott JE, Shutt L, 1993. Monitoring organochlorines in blood of sharp-shinned hawks (Accipiter striatus) migrating through the Great Lakes. Environ Toxicol Chem 12: 241-250.

Elliott JE, Harris ML, 2001. An ecotoxicological assessment of chlorinated hydrocarbon effects on bald eagle populations. Rev. Toxicol., 4: 1-60.

Elliott JE, Norstrom RJ, Lorenzen A, Hart LE, Philibert H, Kennedy SW, Stegeman JJ, Bellward GD, Cheng KM, 1996. Biological effects of polychlorinated dibenzo-p-dioxins, dibenzofurans, and biphenyls in bald eagle (Haliaeetus leucocephalus) chicks. Environ. Toxicol. Chem., 15: 782-793.

Environment Canada, 2005. http://www.on.ec.gc.ca/wildlife/wildspace/introe.html

Elliott KH, Cesh LS, Dooley JA, Letcher RJ, Elliott JE, 2009. PCBs and DDE, but not PBDEs, increase with trophic level and marine input in nestling bald eagles. Science of The Total Environment. 407(12): 3867-3875.

Fisher DA, Dussault JS, Chopra IJ, 1997. Ontogenesis of hypothalamic-pituitarythyroid function and metabolism in man, sheep, and rat. Rec. Progr. Horm. Res. 33:59-116.

Fowles JR, Fairbrother A, Beacher-Steppan L, Kervliet NI, 1994. Immunologic and endocrine effects of the flame retardant pentabromodiphenyl ether (DE-71) in C57BL/6J mice. Toxicology 86: 49-61.

Fox GA, Gilman AP, Peakall DB, Anderka FW, 1978. Behavioral abnormalities of nesting Lake Ontario herring gulls. J. Wildl. Manage. 42: 477-479.

Fox GA, 1993. What have biomarkers told us about the effects of contaminants on the health of fish-eating birds in the Great Lakes? The theory and a literature review. Journal of Nutrition 125: 722-736.

Fox GA, Trudeau S, Won H, Grasman KA, 1998. Monitoring the elimination of persistent toxic substances from the Great Lakes; chemical and physiological evidence from adult herring gulls. Environ Monit Assess 53: 147-168.

Friesema ECH, Jansen J, VisserTJ, 2005. Thyroid hormone transporters. Biochemical Society Transactions 33: 228-232.

Freeman TB, McNabb FMA, 1991. Hepatic 5'-Deiodinase Activity of Japanese Quail Using Reverse ${ }^{\wedge}$ as Substrate: Assay Validation, Characterization, and Developmental Studies. Journ of Exper Zool 258: 212-220. 
Fry DM, Toone CK, 1981. DDT-induced fertilization of gull embryos. Science 213:922-924.

Furness RW, Greenwood JJD, Jarvis PJ, 1993. Can birds be used to monitor the environment? In : R.W. Furness and J.J.D. Greenwood (Eds.), Birds as Monitors of Environmental Change, Chapman \& Hall, London, pp. 1-42.

Gabrielsen GW, Skaare JU, Polder A, Bakken V, 1995. Chlorinated hydrocarbons in Glaucous Gull (Larus hyperboreus) at the southern part of Svalbard. Sci Tot Environ 160/161: 337-346.

Gard NW, Hooper MJ, Bennett RS, 1995. An assessment of potential hazards of pesticides and environmental contaminants. In : T.E. Martin, D.M. Finch (Eds.), Status and Management of Neotropical Migratory Birds, US Wildl. Serv. Gen. Tech. Report RM-229, pp. 310-314.

Gauthier J, Aubry Y, editors. 1996. The breeding birds of Quebec: Atlas of the Breeding Birds of Southern Quebec. Association Quebecoise des groupes dornithologues, Province of Quebec Society for the Protection of Birds, and Canadian Wildlife Service, Quebec Region, Environment Canada, Montreal.

Gauthier LT, Potter D, Hebert CE, Letcher RJ, 2009. Temporal Trends and Spatial Distribution of Non-polybrominated Diphenyl Ether Flame Retardants in the Eggs of Colonial Populations of Great Lakes Herring Gulls. Environ Sci Technol 43(2): 312-317.

Giesy JP, Ludwig JP, Tillit DE, 1994. Deformities in birds of the Great Lakes region: assigning causality. Environ Sci Technol 28(3): 128-135.

Gilbertson M, Elliott JE, Peakall DB, 1987. Seabirds as indicators of marine pollution. ICBP Tech. Publ., 6: 231-248.

Godfrey WE, 1986. The birds of Canada. Revised edition. National Museums of Canada. Ottawa, Ontario, Canada. 595 pp.

Goldstein, M.I., B. Woodbridge, M.E. Zaccagnini, S.B. Canavelli and A. Lanusse, 1996. Assessment and mortality of Swainson's hawks in Argentina. J. Raptor. Res., 30: 106-107.

Grasman KA, Fox GA, Scanlon PF, Ludwig JP, 1996. Organochlorine-associated immunosuppression in prefledgling Caspian terns and herring gulls from the Great Lakes: An ecoepidemiological study. Env Health Perspec 104: 829-842.

Grassle B, Biessmann A, 1982. Effects of DDT, polychlorinated biphenyls and thiouracil on circulating thyroid hormones, thyroid histology and eggshell quality 
in Japanese quail (Coturnix coturnix japonica). Chem-Biol Interactions 42: 371377.

Griffin H, Windsor D, Borlakoglu J, 1991. Changes in plasma lipoprotein metabolism in chicks in response to polychlorinated biphenyls (PCBs). Biochemical Pharmacology, 42(7): 1493-1495.

Guillette Jr LJ, Crain DA, 1996. Endocrine-disrupting contaminants and reproductive abnormalities in reptiles. Toxicology 5: 381-399.

Guruge KS, Tanabe S, 1997. Congener specific accumulation and toxic assessment of polychlorinated biphenyls in common cormorants, Phalacrocorax carbo, from the Lake Biwa Japan Environ Pollut 96: 425-433.

Guruge KS, Tanabe S, Fukuda M, 2000. Toxic assessment of PCBs by the 2,3,7,8-tetrachlorodibenzo-p-dioxin equivalent in common cormorant (Phalacrocorax carbo) from Japan. Arch Environ Contam Toxicol 38: 509-521.

Guruge K, Watanabe M, Tanaka H, Tanabe S, 2001. Accumulation status of persistent organochlorines in albatrosses from the North Pacific and the Southern Ocean. Environ Pollut 114: 389-398.

Hakk H, Letcher RJ, 2003. Metabolism in the toxicokinetics and fate of brominated flame retardants B, A review. Enviro Int 29: 801-826.

Hallgren S, Sinjari T, Hakanssson H, Darnerud PO, 2001. Effects of polybrominated diphenylethers (PBDEs) and polychlorinated biphenyls (PCBs) on thyroid hormone and vitamin A levels in rats and mice. Arch Toxicol 75: 200208.

Hasayi M, 2005. Molecular Cloning and Characterization of Human PDE8 Isozymes of 3',5'Cyclic.http://www.mcmaster.ca/inabis98/pharmtox/hayashi0585/two.html. Nucleotide Phosphodiesterase. University of McMaster Canada

Hebert CE, Sprules WG, 2002. The relevance of seabird ecology to Great Lakes management. J Great Lakes Res 28: 91-103.

Hebert CE, Norstrom RJ, Weseloh DV, 1999. A quarter century of environmental surveillance: the Canadian Wildlife Service's Great Lakes Herring Gull monitoring program. Environ Reviews 7: 147-166.

Hebert CE, Hobson KA, Shutt JL, 2000. Changes in food web structure affect rate of PCB decline in herring gull (Larus argentatus) eggs. Environmental Science and Technology 34: 1609-1614. 
Henney CJ, Ward FP, Riddle KE, Prouty RM, 1982. Migratory peregrine falcons, Falcus peregrinus, accumulate pesticides in Latin America. Can Field Nat 96: 333-338.

Henny CJ, Blus LJ, 1986. Radiotelemetry locates wintering grounds of DDEcontaminated black-crowned night-herons. Wildl Soc Bull 14: 236-241.

Helgason LB, Barrett R, Lie E, Polder A, Skaare JU, Gabrielsen GW, 2008. Levels and temporal trends (1983-2003) of persistent organic pollutants (POPs) and mercury $(\mathrm{Hg})$ in seabird eggs from Northern Norway. Environmental Pollution 155(1): 190-198.

Herrera A, Arino A, Conchello MP, Lazaro R, Bayarri R, Yague C, Peiro JM, Aranda S, Simon MD, 2000. Red-legged partridges (Alectoris rufa) as bioindicators for persistent chlorinated chemicals in Spain. Arch Environ Contam Toxicol 38: 114-120.

Herzke D, Berger U, Kallenborn R, Nygard T, Vetter W, 2005. Brominated flame retardants and other organobromines in Norwegian predatory bird eggs. Chemosphere 61(3):441-449.

Hickey JJ, Anderson DW, 1968. Chlorinated hydrocarbons and egg shell changes in raptorial and fish eating birds. Science 162: 271-273.

Hoshi H, Minamoto N, Iwata H, Shiraki H, Tatsukawa R, Tanabe S, Fujita S, Hirai K, Kinjo T, 1998. Organochlorine pesticides and polychlorinated biphenyl congeners in wild terrestrial mammals and birds from Chubu region Japan: interspecies comparison of the residue levels and compositions. Chemosphere, $36: 3211-3221$.

Isaksen K, Bakken V, 1995. Breeding populations of seabirds in Svalbard. In: Seabird populations in the northern Barents Sea. Source data for the impact assessment of the effect of oil drilling activity (Eds. Isaaksen, $\mathrm{K}$ and $\mathrm{V}$. Bakken). Norsk Polarinstitutte Meddelelser Nr 135: 11-35.

Jefferies DJ, French MC, 1971. Hyper- and hypothyroidism in pigeons fed DDT: an explanations for the thin eggshell phenomenon. Environ Pollut 1: 235-242.

Jefferies DJ, Parslow JFL, 1972. Effect of one polychlorinated biphenyl on size and activity of the gull thyroid. Bull Environ Contamin Toxicol 8: 306-310.

Jefferies DJ, French MC, 1973. Changes induced in the pigeon thyroid by p.p'DDE and dieldrin. Journal of Wildlife Management 36(1): 24-30. 
Jenssen BM, Nielssen VH, Murvoll KM, Skaare JU, 2001. PCBs, TEQs and plasma retinol in grey heron (Ardea cinerea) hatchlings from two rookeries in Norway. Chemosphere, 44: 483-489.

Kallenborn R, Planting S, Haugen J, Nybe S, 1998. Congener-, isomer and enantomer- specific distribution of organochlorines in dippers (Cinclus cinclus L.) from southern Norway. Chemosphere 37 : 2489-2499.

Kannan K, Falandysz J, Tanabe S, Tatsukawa R, 1993. Persistent organochlorines in harbour porpoises from Puck Bay, Poland. Mar Pollut Bull 26: 162-165.

Klemens JA, Harper RG, Frick JA, Capparella AP, Richardson HB, Coffey MJ, 2000. Patterns of organochlorine pesticide contamination in neotropical migrant passerines in relation to diet and winter habitat. Chemosphere 41: 1107-1113.

Kissa E, 2001. In Fluorinated Surfactants and Repellents. Surfactant science series 97 Marcel Dekker Inc., New York, 615 pp.

Konstantinou IK, Goutner V, Albanis TA, 2000. The incidence of polychlorinated biphenyl and organochlorine pesticide residues in the eggs of the cormorant (Phalacrocorax carbo sinensis): an evaluation of the situation in four Greek wetlands of international importance. The Sci Total Environ 257: 61-79.

Kudo N, Kawashima Y, 2003. Toxicity and toxicokinetics of perfluorooctanoic acid in humans and animals. Toxicol. Sci. 28(2): 49-57.

Kunisue T, Watanabe M, Subramanian AN, Sethuraman A, Titenko A, Qui V, Prudente and S. Tanabe, 2003. Accumulation features of persistent organochlorines in resident and migratory birds from Asia. Environ. Pollut 125:157-172.

Kunisue T, Minh TB, Fukuda K, Watanabe K, Tanabe S, Titenko AM, 2002. Seasonal variation of persistent organochlorine accumulation in birds from Lake Baikal, Russia, and the role of the south Asian region as a source of pollution for wintering migrants. Environ Sci Technol, 36: 1396-1404.

Kunisue T, Tanabe S, 2009. Hydroxylated polychlorinated biphenyls (OH-PCBs) in the blood of mammals and birds from Japan: Lower chlorinated OH-PCBs and profiles. Chemosphere 74(7): 950-961.

Lacher TE, Goldstein MI, 1997. Tropical ecotoxicology. Status and needs. Environ. Toxicol Chem 16: 100-111.

Lans MC, Klasson-Wehler E, Willemsen M, Meussen E, Safe S, Brouwer A, 1993. Structure- dependent, competitive interaction of hydroxy- 
polychlorobiphenyls, -dibenzo-p-dioxins and dibenzofurans with human transthyretin. Chem-Biol Interactions 88:7-21.

Larsson $\mathrm{P}$, Lindegren A, 1987. Animals need not be killed to reveal their body burdens of chlorinated hydrocarbons. Environ Pollut 45: 3-78.

Lau C, Anitole K, Hodes C, Lai D, Pfahles-Hutchens A, Seed J, 2007. Perfluoroalkyl acids: A review of monitoring and toxicological findings. Toxicol. Sci. 99(2): 366-394.

Lau C, Butenhoff JL, Rogers JM, 2008. The developmental toxicity of perfluoroalkyl acids and their derivatives. Toxicol Appl Pharmacol 198: 231-241.

Legler J, Brouwer A, 2003. Are brominated flame retardants endocrine disruptors? Environment International. 29(6): 879-885.

Lemmetyinen R, Rantamaki P, Karlin A, 1982. Levels of DDT and PCBs in different stages of life cycle of the Arctic tern, Sterna paradisaea and the herring gull, Larus argentatus. Chemosphere 11: 1059-1068.

Leonard JL, Visser TJ, 1986. Biochemistry of deiodination In: Hennemann G. ed. Thyroid Hormone Metabolism. W. B. Saunders, Philadelphia, 189-229 pp.

Leonard JL, Koehrle J, 1996. Werner and Ingbar's The Thyroid a Fundamental and Clinical Text 7th ed. Philadelphia: Harper \& Row Inc., 125-161 pp.

Leonard JL, Koehrle J, 1996. Intracellular pathways of iodothyronine metabolism. In: Braverman L, Utiger $\mathrm{R}$ (eds) The Thyroid, ed 7. Lippincott-Raven, Philadelphia, pp 125-161 pp.

Letcher RJ, Stapleton HM, Verreault J, McKinney M, Scipione F, Gabrielsen G, Chu S, Valters K, 2004. New case examples of biotransformation and elimination of polybrominated diphenyl ethers in aquatic and marine wildlife. The Third International Workshop on Brominated Flame Retardants BFR2004. University of Toronto Toronto, Ontario, Canada June 6-9, 2004

Letcher RJ, Norstrom RJ, Muir DCG, Sandau CD, Koczanski K, Michaud R, DeGuise S, Beland $P, 2000$. Methylsulfone polychlorinated biphenyl and 2,2bis(chlorophenyl)-1,1- dichloroethylene metabolites in beluga whale (Delphinapterus leucas) from the St. Lawrence River estuary and western Hudson Bay, Canada. Environmental Toxicology and Chemistry 19(5): 13781388.

Letcher RJ, Bustnes JO, Dietz R, Jenssen BM, Jorgensen EH, Sonne C, Verreault J, Vijayan MM, Gabrielsen GW, 2009. Exposure and effects assessment of persistent organohalogen contaminants in arctic wildlife and fish. 
Sci of The Total Environm, In Press (accessed online 12 November 2009).

Li MH, Zhao YD, Hansen LG, 1994. Multiple dose toxicokinetic influence on the estrogenecity of 2,2,4,4,5,5-hexachlorobiphenyl. Bull Environ Contain Toxicol 53: 583-590.

Li H, Drouillard KG, Bennett E, Haffner GD, Letcher RJ, 2003. Plasmaassociated halogenated phenolic contaminants in benthic and pelagic fish species from the Detroit River. Environ Sci Technol 37(5): 832-839.

Luebker DJ, Hansen KJ, Bass NM, Butenhoff JL, Seacat AM, 2002. Interactions of fluorochemicals with rat liver fatty acid-binding protein. Toxicology 176: 175185.

Mayer LP, Tori GM, 1981. Effects of polychlorinated biphenyls on the metabolic rates of morning doves exposed to low ambient temperatures. Bull Environm Contam Toxicol 27: 678-682.

McArthur MLB, Fox GA, Peakall DB, Philogene BJR, 1983. Ecological Significance of behavioral and hormonal abnormalities in breeding ring doves fed an organochlorine chemical mixture. Environ Contam and Tox 12: 343-353.

McCleary RJR, McNabb FMA, Grasman KA, 2000. UDP-glucuronosyltransferase (UDP-GT) activity in PCB-treated chicken embryos. Presented at the Gordon Research Conference on Endocrine Disruptors, Plymouth State College, Plymouth, NH, June 18-23, 2000.

McDonald TA, 2002. A perspective on the potential health risks of PBDEs. Chemosphere 46: 745-755.

McKinney JD, Fawkes J, Jordan S, Chae K, Oatley S, Coleman RE, Briner W, 1985. 2,3,7,8-Tetrachlorodibenzo-p-Dioxin (TCDD) as a Potent and Persistent Thyroxine Agonist: A Mechanistic Model for Toxicity Based on Molecular Reactivity. Environ. Health Perspectives 61: 41-53.

McNabb FMA, Hughes TE, 1983. The role of serum binding proteins $n$ determining free thyroid hormone concentrations during development in quail. Endocrinology 113: 957- 963.

McNabb FMA, Cheng MF, 1985. Thyroid development in altricial ring doves, Streptopelia risoria. General and Compar Endocrinol 58:243-251.

McNabb A, 1992. Thyroid hormones: production, storage, and release by the thyroid gland. In: Thyroid Hormones (McNabb A, ed). Englewood Cliffs, NJ:Prentice Hall, 21-48. 
McNabb FMA, King DB, 1993. Thyroid hormone effects on growth, development and metabolism. In The Endocrinology of Growth, Development, and Metabolism in Vertebrates (PKT Pang, CG Scanes and MP Schreibman, eds.). New York: Academic Press, pp. 393-417.

McNabb FMA, Scanes CG, Zeman M, 1998. Endocrine control of development. In: Starck, J.M. and Ricklefs, R.E., Editors, 1998. Avian Growth and Development, Oxford University Press, New York, pp. 174-202.

McNabb FMA, 1999. Altricial and precocial development in birds. Encyclopedia of Reproduction vol 1, 113-118.

McNabb FMA. 2000. Thyroids. In: Sturkie's Avian Physiology (Whittow GC, ed). 5th ed. London:Academic Press, 461-471.

McNabb FMA, Fox A, Fox GA, 2003. Avian thyroid development in chemically contaminated environments: is there evidence of alterations in thyroid function and development? Evolution \& Development. 5(1):74-76.

McNichols MJ, McNabb FMA, 1988. Development of thyroid function and its pituitary control in embryonic and hatchling precocial Japanese quail and altricial Ring doves. Gen Comp Endocrinol 69: 109-118.

Meerts IATM, van Zanden JJ, Luijks EAC, van Leeuwen-Bol I, Marsh G, Jakobsson E, Bergman A, Brouwer A, 2000. Potent Competitive Interactions of Some Brominated Flame Retardants and Related Compounds with Human Transthyretin in Vitro. Toxicological Sciences 56: 95-104.

Mehlum F, Daelemans FF, 1995. PCBs in Arctic seabirds from the Svalbard region. Science of The Total Environment. 160-161: 441-446.

Mehlum F, Bakken V, 1994. Seabirds in Svalbard (Norway): status, recent changes and management. In: Seabirds on islands: threats, case studies and action plans. Bird Life Conservation Series No 1 (Eds. Nettleship, D.N., Burger, J. \& Gochfeld, M.): 155-171.

Merryman JI, Buckles EL, 1998a. The avian thyroid gland. Part one: a review of the anatomy and physiology. J Avian Med Surg 12: 234-237.

Merryman JI, Buckles EL.1998b. The avian thyroid gland. Part two: a review of function and pathophysiology. J Avian Med Surg 12: 238-242.

Mineau P, Fox GA, Norstrom RJ, Weseloh DV, Hallett DJ, Ellenton JA, 1984. Using the herring gull to monitor levels and effects of organochlorine contamination in the Canadian Great Lakes. In Toxic Contaminants in the Great 
Lakes (JD Nriagu, MS Simmons, eds.). New York: John Wiley \& Sons, pp. 425452.

Minh, TB, Kunisue T, Yen NTH, Watanabe M, Tanabe S, Hue ND, Qui V, 2002. Persistent organochlorine residues and their bioaccumulation profiles in resident and migratory birds from North Vietnam. Environ Toxicol Chem 21:2108-2118.

Mississippi State University, 2005. http://www.msstate.edu/dept/poultry/avianemb.htm. 2005 Avian Embryo Poultry Science Home Page, College of Agriculture \& Life Sciences. Mississippi State University.

Moccia RD, Fox GA, Britton A, 1986. A Quantitative assessmemt of thyroid histopathology of Herring Gulls (Larus Argentatus) from the great lakes and a hypothesis on the casual role of environmental contaminants. J. Wildlife Disease 22(1): 60-70.

Moore NW, Ratcliffe DA, 1962. Chlorinated hydrocarbon residues in the egg of a peregrine falcon (Falco peregrinus) from Perthshire. Bird Study, 9 : 242-244.

Morse D, Brouwer A, 1994. Perinatal alterations of thyroid hormone homeostasis and long term neurochemical alterations in rats following maternal Aroclor 1254 exposure. Organohalogen Compounds 21: 439.

Morse DC, Groen D, Veerman M, Van Amerongen CJ, Koeter DBWM, Smits Van Prooije, AE, Visser TJ, Koeman JH, Brouwer A, 1993. Interference of Polychlorinated Biphenyl in Hepatic and Brain Thyrid Hormone Metabolism in Fetal and Neonatal Rats. Toxicol Appl Pharmacol 122: 27-33.

Morse DC, Wehler EK, Wesseling W, Koeman JH, Brouwer A, 1996. Alterations in rat brain thyroid hormone status following pre- and postnatal exposure to polychlorinated biphenyls (Aroclor 1254). Toxicology and Applied Pharmacology 136:269-279.

Muir DCG, Braune B, DeMarch B, Norstrom RJ, Wagemann R, Lockhart L, Hargrave B, Bright D, Addison R, Payne J, Reimer K, 1999. Spatial and temporal trends and effects of contaminants in the Canadian Arctic marine ecosystem: A review. The Sci Total Environ 230: 83-144.

Murk AJ, Van den Berg JHJ, Fellinger M, Rozemeijer MJC, Swennen C, Duiven P, Boon JP, Brouwer A, Koeman JH, 1994b. Toxic and biochemical effects of 3,3',4,4'- tetrachlorobiphenyl (CB-77) and Clophen A50 on eider ducklings (Somateria mollissima) in a semi-field experiment. Environ Pollut 86: 21-30.

National Audubon Society, 2005. http://www.audubon.org/ (acceded on-line October 2009) 
Ness DK, Schantz SL, Moshtaghian J, Hansen LG, 1993. Effects of perinatal exposure to specific PCB congeners on thyroid hormone concentrations and thyroid histology in the rat. Toxicology Letters 68: 311-323.

Nessel CS, Gallo MA, 1992. Dioxins and Related Compounds. In:EnvironmentalToxicants. Human Exposures and their Health Effects, ed. M. Lippmann., New York: Van- Nostrand Reinhold. Ch. 6: 163-183.

Nice MM, 1962. Development of behavior in precocial birds. Trans. Linn. Soc. (NY) 8: 1-211.

Norris DO, 1997. Vertebrate Endocrinology, 3th Edition. Academic Press, pp 634.

Norstrom RJ, Risebrough RW, Cartwright CJ, 1976. Elimination of chlorinated dibenzofurans associated with polychlorinated biphenyl fed to mallard (Anas platyrhynchos). Toxicol. Appl. Pharmacol., 37: 217-228.

NRDC, 2009. Endocrine Disrupters, steaming the tide of toxic chemicals. Annual Report 2008. New York, USA, http://www.nrdc.org (accessed online October 2, 2009)

Natural Resources Defense Council.

Olafsdottir K, Skirnisson K, Gylfaottir G, Johannesson T, 1998. Seasonal fluctuations of organochlorine levels in the common eider (Somateria mollissima) in Iceland. Environ. Pollut 103: 153-158.

Oppenheimer $\mathrm{JH}$, 1983. The nuclear receptor-thyroid hormone complex: relationship to thyroid hormone distribution, metabolism, and biologic action. In: Oppenheimer JH, Samuels HH (eds) Molecular Basis of Thyroid Hormone Action. Academic Press.New

York, pp 1-32

Ove Bustnes J, Helberg M, Strann KB, Skaare JU, 2006. Environmental pollutants in endangered vs. increasing subspecies of the lesser black-backed gull on the Norwegian Coast. Environ Poll 144:893-901

Oxynos K, Schmitzer J, Ketrrup A, 1993. Herring gull eggs as bioindicators for chlorinated hydrocarbons (Contribution to the German Federal Environmental Specimen Bank). Sci Total Environ 139/140: 387-398.

Pain DJ, Burneleau G, Bavoux C, Wyatt C, 1999. Levels of polychlorinated biphenyls, organochlorine pesticides, mercury and lead in relation to shell thickness in marsh harrier (Circus aeruginosas) eggs from Charente-Maritime, France. Environ Pollut 104: 61-68. 
Parkinson A, Safe S, 1987. Mammalian biologic and toxic effects of PCBs. In : S. Safe (Ed.), Polychlorinated biphenyls (PCBs): Mammalian and Environmental Toxicology (Environmental Toxin Series I), Springer, Berlin, pp. 49-75.

Parslow JLF, Jefferies DJ, 1977. Gannets and toxic chemicals. Brit Birds 70: 366-372.

Peakall DB, Peakall ML, 1973. Effect of a polychlorinated biphenyl on the reproduction of artificially and naturally incubated dove eggs. J Appl Ecol 10: 103.

Peakall, DB, 1974. DDE: its presence in peregrine eggs in 1948. Science 183 : 673-674.

Peakall, DB, 1990. Prospects for the peregrine falcon, Falco peregrinus, in the nineties. Can Field Nat 104: 168-173.

Pierotti RJ, Good TP, 1994. Herring Gull. In A. Poole, P. Stettenheim, and F. Gill, editors. The Birds of North America, no. 124. Academy of Natural Sciences, Philadelphia, Pennsylvania; and American Ornithologists Union, Washington, D.C.

Powell DC, Aulerich RJ, Meadows JC, Tillitt DE, Giesy JP, Stromborg KL, Bursian SJ, 1996. Effects of 3,3',4,4',5-pentachlorobiphenyl (PCB 126) and 2,3,7,8-tetrachlorodibenzo-p-dioxin (TCDD) injected into the yolks of chicken (Gallus domesticus) eggs prior to incubation. Environ Contam and Tox 31: 404409.

Quinn MJ, French JB, McNabb FMA, Ottinger MA, 2002. The effects of polychlorinated biphenyls (Aroclor 1242) on thyroxine, estradiol, molt, and plumage characteristics in the American kestrel (Falco sparverius). Environmental Toxicology and Chemistry 21 (7): 1417-1422.

Ramesh A, Tanabe S, Kannan K, Subramanian AN, Kumaran PL, Tatsukawa R, 1992. Characteristic trend of persistent organochlorine contamination in wildlife from a tropical agricultural watershed, South India. Arch Environ Contam Toxicol 23: $26-36$.

Ratcliffe DA, 1967. Decrease in eggshell weight in certain birds of prey. Nature 215:208-210.

Rickenbacher U, McKinney JD, Oatley SJ, Blake CCF, 1986. Structurally specific binding of halogenated biphenyls to thyroxine transport protein. Journal of Med Chem 29: 641-648. 
Riviere JL, De Lavaur E, Grolleau G, 1978. Effect of polychlorinated biphenyls on drug metabolism in Japanese quail and its progeny. Toxicology 11: 329-334.

Robbins J, 1996. Werner and Ingbar's The Thyroid a Fundamental and Clinical Text 7th ed. Philadelphia: Harper \& Row Inc 96-110.

Rolland RM, 2000. A review of chemically-induced alterations in thyroid and vitamin A status from field studies of wildlife and fish. J Wildl Dis 36: 615-635.

Rudas P, Bartha T, Frenyo LV, 1993. Thyroid hormone deiodination in the brain of young chickens acutely adapts to changes in thyroid status. Acta Veterinaria Hungarica 41 : 381-393.

Ryckman D, Weseloh DV, Bishop CA, 1997. Contaminants in Herring Gull eggs from the Great Lakes: 25 years of monitoring levels and effects. Great Lakes Fact Sheet. Canadian Wildlife Service, Ontario Region, Burlington.

Raasmaja A, Viluksela M, Rozman KK, 1996. Decreased liver type I 5'deiodinase and increased brown adipose tissue type II 5'-deiodinase activity in 2,3,7,8- tetrachlorodibenzo-p-dioxin (TCDD)-treated Long-Evans rats. Toxicology $114,199-205$.

Saeed A, Hansen LG, 1997. Morphometric changes in the prepubertal female rat thyroid gland following acute exposure to 2,2',4,4'-tetrachlorobiphenyl and Aroclor 1242. J. Toxicol Environ Health 51: 503-513.

Safe SH, 1990. Polychlorinated biphenyls (PCBs), dibenzo-p-dioxins (PCDDs), dibenzofurans (PCDFs) and related compounds: environmental and mechanistic considerations which support the development of toxic equivalency factors (TEFs). CRC Crit Rev Toxicol 21:51.

Sakamoto KQ, Kunisue T, Watanabe M, Masuda Y, Iwata H, Tanabe S, Akahori F, Ishizuka M, Kazusaka A, Fujita S, 2002. Accumulation patterns of polychlorinated biphenyl congeners and organochlorine pesticides in Steller's sea eagles and white-tailed sea eagles, threatened species, in Hokkaido, Japan. Environ Toxicol Chem 21: 842-847.

Sandala GM, Sonne-Hansen C, Dietz R, Muir DCG, Valters K, Bennett ER, 2004. Born, E. W.; Letcher, R. J. Hydroxylated and methyl sulfone PCB metabolites in adipose and whole blood of polar bears (Ursus maritimus) from East Greenland. Sci Total Environ 331: 125-141.

Santos CRA, Power DM, 1999. Identification of Transthyretin in Fish (Sparus aurata): cDNA Cloning and Characterisation Endocrinology 14(5): 2430-2433. 
Scharenberg W, 1991. Cormorants (Phalacrocorax carbo sinenesis) as bioindicators for polychlorinated biphenyls. Arch. Environ. Contam Toxicol 21 : 536-540.

Schuur, A, Bergman G, Coughtrie MW, Visser TJ, 1998. Inhibition of thyroid hormone sulfation by hydroxylated metabolites of polychlorinated biphenyls. Chem. Biol. Interact. 109: 293-297.

Schwarz TR, Stalling DL, 1991. Chemometric comparison of polychlorinated residues and toxicologically active biphenyl congeners in the eggs of Forster's terns (Sterna foresteri). Arch Environ Contam Toxicol 20:183-199.

Seacat AM, Thomford PJ, Hansen KJ, Clemen LA, Eldridge SR, Elcombe CR, Butenhoff JL, 2003. Sub-chronic dietary toxicity of potassium perfluorooctanesulfonate in rats. Toxicology 183: 117-131.

Senthilkumar K, Kannan K, Tanabe S, Prudente M, 1998. Butyltin compounds in resident and migrant birds collected from Philippines. Fres Environ Bull 7: 561571.

Sinkkonen S, Rantalainen AL, Paasivirta J, Lahtipera M, 2004. Polybrominated methoxy diphenyl ethers (MeO-PBDEs) in fish and guillemot of Baltic, Atlantic and Arctic environments. Chemosphere 56(8): 767-775

Skutch AF, 1976. Parent birds and their young. University of Texas Press, Austin $513 \mathrm{pp}$.

Somack R, Andrea TA, Jorgensen EC, 1982. Thyroid hormone binding to human serum prealbumin and rat nuclear receptor: kinetics, contribution of the hormone phenolic hydroxy! group, and accommodation of hormone side-chain bulk. Biochemistry 21: 163-170.

Springer AM, Walker MW, Risebrough RW, Benfield D, Ellis DH, Mattox WG, Mindell DP, Roseneau DG, 1984. Origins of organochlorines accumulated by peregrine falcons, Falco peregrinus, breeding in Alaska and Greenland. Can Field Nat 98: 159-166.

Starck JM, Ricklefs RE, 1998. Patterns of development: the altricial-precocial spectrum. In Avian Growth and Development, Evolution within the AltricialPrecocial Spectrum (JM Starck and RE Ricklefs, eds.). New York: Oxford University Press, pp. 3-30.

Starck JM, 1993. Evolution of avian ontogenies. Curr Orn 10: 275-366. 
Stickel LF, Stickell WH, Christensen R, 1966. Distribution of DDT residues in brains and bodies of birds that died on dosage and in survivors. Science 151: 1549-1551.

Tanabe S, 2002. Contamination and toxic effects of persistent endocrine disrupters in marine mammals and birds. Mar Pollut Bull 45: 69-77.

Tanabe S, Subramanian AN, Hidaka H, Tatsukawa R, 1986. Transfer rates and patterns of PCB isomers and congeners and p,p'-DDE from mother to egg in Adelie penguin (Pygoscelis adeliae). Chemosphere 15: 343-351.

Tanabe S, Senthilkumar K, Kannan K, Subramanian AN, 1998. Accumulation features of polychlorinated biphenyls and organochlorine pesticides in resident and migratory birds from South India. Arch. Environ. Contam Toxicol 34 :387397.

Tanabe S, Watanabe M, Minh TB, Kunisue T, Nakanishi S, Ono H, Tanaka H, 2004. PCDDs, PCDFs and coplanar PCBs in albatross from the North Pacific and the Southern Ocean: levels, patterns and toxicological implications. Environ. Sci Technol Environ Sci Technol 38(2):403-13.

Tanabe S, Watanabe S, Kan S, Tatsukawa R, 1988. Capacity and mode of PCB metabolism in small cetaceans. Mar Mam Sci 4: 103-124.

Teuten L, Xu L, Reddy CM, 2005. Two abundant bioaccumulated halogenated compounds are natural products. Science 307: 917-920.

Thibodeaux JR, Hanson RG, Rogers JM, Grey BE, Barbee BD, Richards JH, Butenhoff JL, Stevenson LA, Lau C, 2003. Exposure to perfluorooctane sulfonate during pregnancy in rat and mouse. I: Maternal and prenatal evaluations. Toxicol Sci 74: 369-381.

Thommes RC, 1987. Ontogenesis of thyroid function and regulation in the developing chick embryo. J Exp Zool 1: 273-279.

Thyen S, Becker PH, Behmann H, 2000. Organochlorine and mercury contamination of little terns (Sterna albifrons) breeding at western Baltic Sea. Environ Pollut 108: 225-238.

Tillitt DE, Ankley GT, Giesy JP, 1989. Planar chlorinated hydrocarbons (PCHs) in colonial fish-eating waterbird eggs from the Great Lakes. Marine Environmental Research, $28 \quad(1-4)$ 505-508.

Tillitt DE, Ankley GT, Verbrugge DA, Giesey JP, Ludwig JP, Kubiak TJ, 1991. H4IIE rat hepatoma cell bioassay-derived 2,3,7,8-tetrachlorodibenzo-p- dioxin 
equivalents in colonial fish-eating bird eggs from the Great lakes. Arch Environ Contam Toxicol 21: 91-101.

Tillitt DE, Ankley GT, Giesey JP, Ludwig JP, Kuirta-Matsuba H, Weseloh DV, Ross PS, Bishop S, Seleo L, stromborg KL, Larson L, Kubiak TJ, 1992. Polychlorinated biphenyl residues and egg mortality in double-crested cormorants from the Great Lakes. Environ Toxicol Chem 11: 1281-1288.

Tilson HA, Jacobson JL, Rogan WJ, 1990. Polychlorinated biphenyls and developing nervous system: cross species comparisons. Neurotoxicol Teratol 12: 239-248.

Traag WA, Kan CA, van der Weg G, Onstenk C, Hoogenboom LAP, 2006. Residues of dioxins (PCDD/Fs) and PCBs in eggs, fat and livers of laying hens following consumption of contaminated feed. Chemosphere 65(9): 1518-1525.

Umpierrez GE, 2002. Pituitary-Thyroidal Axis During Systemic Illness. South Med J 95(5): 78-83.

University of Guelph, 2005. http://www.uoguelph.ca/zoology/devobio/miller/ Cell and Developmental Biology On-line (accessed October 2009). University of Guelph.

Van Birgelen APJM, Smit EA, Kampen IM, Groeneveld CN, Fase KM, Van der Kolk J, Poiger H, Van den Berg M, Koeman JH, Brouwer A, 1995. Subchronic effects of 2,3,7,8- TCDD or PCBs on thyroid hormone metabolism: use in risk assessment. European Journal of Pharmacology 293: 77-85.

Van Birgelen APJM, Van der Kolk J, Poiger $\mathrm{H}$, Van den Berg $\mathrm{M}$, Brouwer A, 1992. Interactive effects of 2,2',4,4',5,5'-hexachlorobiphenyl and 2,3,7,8tetrachlorodibenzo-pdioxin on thyroid hormone, vitamin $A$, and viamin $K$ metabolism in the rat. Chemosphere 25: 1239-1244.

van den Berg KJ, Zurcher C, Brouwer A, 1988. Effects of 3,3,4,4 tetrachlorobiphenyl on thyroid function and histology in marmoset monkeys. Toxicol Lett $41: 77-86$.

Van den Berg M, Craane BLHJ, Sinnige T, Van Mourik S, Dirksen S, Boudewijn T, Van der Gaag M, Lutke-Schipholt IJ, Spenkelink A, Brouwer A, 1994. Biochemical and toxic effects of polychlorinated biphenyls (PCBs), dibenzo-pdioxins (PCDDs) and dibenzofurans (PCDFs) in the cormorant (Phalacrocorus carbo) after in ovo exposure. Environmental Toxicology and Chemistry 13: 803816. 
Van der Kolk J, Van Birgelen APJM, Poiger H, Schlatter C, 1992. Interactions of $2,2^{\prime}, 4,4^{\prime}, 5,5^{\prime}$ hexachlorobiphenyl and 2,3,7,8-tetrachlorodibenzo-p-dioxin in a subchronic feeding study in the rat. Chemosphere 25: 2023.

Verboven N, Verreault J, Letcher RJ, Gabrielsen GW, Evans NP, 2009. Nest temperature and parental behaviour of Arctic-breeding glaucous gulls exposed to persistent organic pollutants. Animal Behaviour 77(2): 411-418.

Vermeer K, Peakall DB, 1977 Toxic chemicals in Canadian fish-eating birds.

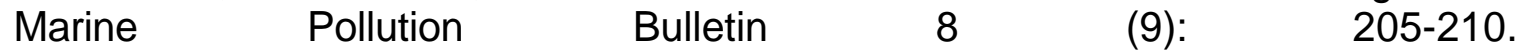

Verreault J, Gabrielsen GW, Letcher RJ, Muir DCG, Chu S, 2004. New and Established Organohalogen Contaminants and Their Metabolites in Plasma and Eggs of Glaucous Gulls from Bear Island Report. SPFO-Report: 914/2004 TAnumber: 2057/2004,ISBN-number: 82-7655-488-1.

Verreault J, Skaare JU, Jenssen BM, Gabrielsen GW, 2004. Effects of Organochlorine Contaminants on Thyroid Hormone Levels in Arctic Breeding Glaucous Gulls, Larus hyperboreus. Environ Health Perspect 112(5): 532-537.

Verrault J, Gabrielsen GW, Chu S, Muir D, Andersen M, Hamaed A, Letcher RJ, 2005. Flame Retardants and Methoxylated and Hydroxylated Polybrominated Diphenyl Ethers in Two Norwegian Arctic Top Predators: Glaucous Gulls and Polar Bears. Environmental science \& technology 39(16): 6021-6028.

Verreault J, Gabrielsen GW, Chu S, Muir DCG, Andersen M, Hamaed A, Letcher RJ, 2005a. Flame Retardants and Methoxylated and Hydroxylated PBDEs in Two Norwegian Arctic Top-Predators: Glaucous Gulls and Polar Bears. Environ Sci Technol 39: 6021-6028.

Verreault, J, Letcher RJ, Muir DCG, Chu S, Gebbink WA, Gabrielsen GW, 2005b. New organochlorine contaminants and metabolites in plasma and eggs of glaucous gulls (Larus hyperboreus) from the Norwegian Arctic. Environ Toxicol Chem 2005b 24(10): 2486-2499..

Vetter W, Klobes U, Luckas B, 2001. Distribution and levels of eight toxaphene congeners in different tissues of marine mammals, birds and cod livers. Chemosphere 43: 611-621.

Walker CH, Knight CG, Chipman JK, Ronis MJJ, 1984. Hepatic microsomal monooxygenases in sea birds. Mar Environ Res 14: 416-419.

Weichert CK, 1953. Elements of Chordate Anatomy, McGraw-Hill publications in the zoological sciences, New York, pp 451. 
Weiss JM, Andersson PL, Lamoree MH, Leonards PEG, van Leeuwen SPJ, Hamers T, 2009. Competitive Binding of Poly- and Perfluorinated Compounds to the Thyroid Hormone Transport Protein Transthyretin. Tox Sci 109(2): 206-216.

Wyatt L, Courts CT, Elcombe CR, 1993. The effect of chlorinated paraffins on hepatic enzymes and thyroid hormones. Toxicology 77: 81-90.

Wyk EV, Bouwman $H$, van der Bank H, Vendoorn GH, Hofmann D, 2001. Persistent organochlorine pesticides in blood and tissue samples of vultures from different localities in South Africa. Comp Biochem Physiol Part C 129: 243-264.

Yamada H, Takayanagi K, Tateishi M, Tagata M, Ikeda K, 1997. Organotin compounds and polychlorinated biphenyls of livers in squid collected from coastal waters and open oceans. Environ Pollut 2: 217-226.

Yamashita N, Tanabe S, Ludwig JP, Kurita H, Ludwig ME, Tatsukawa R, 1993. Embryonic abnormalities and organochlorine contamination in double-crested cormorants (Phalacrocorax auritus) and Caspian terns (Hydroprogne caspia) from the upper Great Lakes in 1988. Environ Pollut 79 :163-173.

Zhou T, Ross DG, deVito MJ, Crofton KM, 2001. Effects of short-term in vivo exposure to polybrominated diphenyl ethers on thyroid hormones and hepatic enzyme activities in weanling rats. Toxicol Sci 61: 76-82.

Zhou T, Taylor MM, DeVito MJ, Crofton KM, 2002. Developmental exposure to brominated diphenyl ethers results in thyroid hormone disruption. Toxicol. Sci. 66: 105-16. 


\section{CHAPTER TWO}

\section{Material and Methods}

\subsection{Samples collection, Gull liver and brain tissues}

Liver and brain samples were collected in 2003 from herring gulls from Lake Ontario from colonies at Hamilton Harbour $(\mathrm{HH})$ and Scotch Bonnett Island (SBI). Tissue samples were collected in cryogenic vials and immediately frozen in liquid nitrogen (LN2) and stored in LN2 at Environment Canada's National Wildlife Specimen Bank (EC-NWSB) in Ottawa (Carleton University). Since the early 1970 's, herring gulls from the Laurentian Great Lakes have been used to monitor trends in levels and effects of OCs (Mineau et al 1984). The present herring gull liver and brain samples were collected as part of the Great Lakes Herring Gull Monitoring Program (GLHGMP) administered by the Canadian Wildlife Service (Environment Canada). All aspects of the sample collections for the GLHGMP have been approved by Environment Canada, and conform to all animal-handling guidelines.

Liver and brain samples from glaucous gulls, collected in 2002 and 2004 at Bear Island (74 ${ }^{\circ} 22^{\prime} \mathrm{N} 19{ }^{\circ} 05^{\prime} \mathrm{E}$; Norwegian Arctic) (Verreault et al 2004), were immediately frozen in $\mathrm{LN} 2$, and stored in an ultra deep-freezer $\left(-80^{\circ} \mathrm{C}\right)$ until 
analysis. All field methods employed in this study were approved by the Governor of Svalbard (2002/00483-2 a. 512/2) and the Norwegian National Animal Research Authority (S1030/02). The capture and handling methods of glaucous gulls were approved by the Norwegian National Animal Research Authority (P.O. Box 8147 Dep., NO-0033 Oslo, Norway) and the Governor of Svalbard (Box 633, NO-9171 Longyearbyen, Norway).

\subsection{Chemicals and reagents}

Trizol@ reagent for RNA purification, TA-cloning kit with pCR2.1 vector and InVision ${ }^{\mathrm{TM}}$ His-tag In-gel staining were purchased from Invitrogen (Carlsbad, CA, USA). IScript cDNA synthesis kit and iTaq DNA polymerase were purchased from Bio-Rad Laboratories (Hercules, CA, USA). The pET28a expression vector was obtained from Novagen (Madison, WI, USA) and BL21-RIPL E.coli cells from Stratagene (La Jolla, CA, USA). His-Trap-FF crude Kit containing $1 \mathrm{ml}$ columns were from GE Healthcare. Human TTR (human pre-albumin, 98\% pure) was purchased from Sigma-Aldrich (Mississauga, ON, Canada). Human recALB

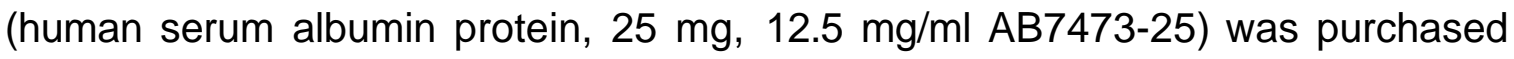
from ABCAM PLC. (Cambridge, MA, U.S.A.). These substrates were CB-187 from AccuStandard Chemical Reference Standards (>99\% purity).

The PCB, PBDE, OH-PCB and OH-PBDE substrates used in the competitive TTR and Albumin binding studies with T4 and T3 were those found to dominate in 
the plasma of Norwegian glaucous gull (Verreault et al 2005a; 2005b). These substrates were CB-187 from AccuStandard Chemical Reference Standards (>99\% purity); and BDE-47 and the structurally analogous $4-\mathrm{OH}-\mathrm{CB} 187,6-\mathrm{OH}-$ BDE47, 4'-OH-BDE49, 4-MeO-CB187 and 6-MeO-BDE47, which were purchased from Cambridge Isotope Laboratories (Cambridge, MA, U.S.A. purity $99 \%$ in nonane). All chemicals used were of high purity, HPLC grade.

\subsection{TTR}

2.3.1 TTR, RNA isolation, CDNA synthesis and PCR

The PCR primers were identified previously as an amino acid sequence set using the BLAST (NCBI) using traces of chicken (Gallus gallus) and using Primer3 (v. 0.4.0; http://mit.edu/), and the primer sequence was purchased from Custom Oligonucleotide Synthesis (Biosearch Technologies Inc, Novato CA 94949). Total RNA was purified using frozen $\left(-80^{\circ} \mathrm{C}\right.$ preserved) brain and liver tissues from herring gull and glaucous gull homogenized in Trizol reagent according to the manufacturer's protocol. The quality of the RNA was determined by agaroseformamide gel electrophoresis, and RNA concentrations were determined using a NanoDrop® Spectrophotometer (NanoDrop Technologies, Wilmington, DE, USA). Total cDNA for the polymerase chain reaction (PCR) were generated from 1 ug total RNA using a combination of random and poly-T primers from a iScript cDNA Synthesis Kit as described by the manufacturer (Bio-Rad Laboratories, Hercules, CA, USA). PCR was used to generate a 924 bp long product of TTR 3'-end. The 50 ul DNA amplification reaction contained 0.25 ul iTaq DNA 
polymerase, 5 pi PCR buffer, $1.5 \mathrm{ul} \mathrm{MgCl}(20 \mathrm{mM}), 1 \mathrm{u}$ ! of cDNA and $200 \mathrm{nM}$ of each TTR forward primer (5'-CTCCCATGGCTCTGTTGATT-3') and reverse primer (5'-TTGTCTGAATTTTTGCCAGGT-3'). The three step PCR program included an enzyme activation step at $95^{\circ} \mathrm{C}(5 \mathrm{~min})$ and 40 cycles of $95^{\circ} \mathrm{C}(1$ $\mathrm{min}), 55^{\circ} \mathrm{C}(1 \mathrm{~min})$, and $72^{\circ} \mathrm{C}(1 \mathrm{~min})$.

One PCR product of 924 bp long representing TTR mRNA (pTTR2 plasmid) for each of brain and liver of herring and glaucous gulls was cloned into pCR2.1 vector and transformed to INVaF in an Escherichia coli (Invitrogen) bacteria culture. Each plasmid was sequenced using an ABI-prism 3100 Genetic Analyzer (Applied Biosystems, Foster City, CA, USA). The aminoacid sequences for each of brain and liver of herring and glaucous gulls were confirmed and compared using NCBI nucleotide BLAST online software (Genbank accession number bankit1047289-EU352211) (http://www.ncbi.nlm.nih.gov/BLAST). The aminoacid sequences of herring and glaucous gull TTR were aligned using ClustalW analysis, and Bootstrap values were obtained after 100 samplings. Positions with gaps were excluded and corrections were made for multiple substitutions.

\subsubsection{TTR, Sequence analysis}

The 924 bp long PCR products representing TTR mRNA from brain and liver of herring and glaucous gulls was cloned into pCR2.1 vector in an Escherichia coli INVaF strain (Invitrogen). TTR containing plasmids were sequenced in both directions using an ABI-prism 3100 Genetic Analyzer (Applied Biosystems, 
Foster City, CA, USA). The generated nucleotide sequences were confirmed using NCBls Basic Local Alignment Search Tool, BLASTx. (http://www.ncbi.nlm.nih.gov/BLAST) and translated into amino acid sequences by the aid of Expasy translation tool (http://us.expasy.Org/tools/\#translate). Multiple sequences were aligned for TTR cDNAs from several vertebrates (Crocodile (CAA11129), frog (NP001081349), zebrafish (AAH81488), human (NP000362), rat (NP036813), chicken (NP990666), duck (ABC65926) and gull (EU352211). Phylogenetic analysis of the TTRs was performed using alignment and the neighbour-joining method (Saitou and Nei, 1987) option of the Phylip program (Galtier et al 1996) with 100 bootstrap replicates. For the construction of the phylogenetic tree, the TTR-like protein sequence of Campylobacter coli (Accession No. EAL57513) was used as an out-group.

\subsubsection{Expression and purification of recombinant TTR (rTTR)}

The cloned TTR gene product was transferred from the pCR2.1 vector into the pET28a E. coli expression vector that generates a 6-times Histidine tag (His-tag) positioned at the N-terminus of the expressed proteins. An E. coli BL21 (RIPL) codon plus strain was used as the expression host. E. coli was grown overnight (ON) in $3 \mathrm{ml}$ Lauria Bertani medium (LB-medium; $5 \mathrm{~g} / \mathrm{L} \mathrm{NaCl}, 5 \mathrm{~g} / \mathrm{l}$ Yeast extract and $10 \mathrm{~g} / \mathrm{l}$ Trypton) containing $50 \mathrm{ug} / \mathrm{ml}$ Kanamycin and $34 \mathrm{ug} / \mathrm{ml}$ chloramphenicol. Thereafter, the synthesis of rTTR was accomplished by inoculating $250 \mathrm{ml}$ of LB-medium without antibiotics with $2.5 \mathrm{ml}$ of overnight (ON) culture. Cells were grown for 2 hours at $37^{\circ} \mathrm{C}$ before the temperature was 
lowered to $30^{\circ} \mathrm{C}$ and recombinant protein expression was induced by addition of isopropyl-3-1-thio-galactopyranoside (IPTG) to a final concentration of $0.5 \mathrm{mM}$. After 4 hours, cells were harvested by centrifugation $(4,200 \times \mathrm{g}, 20$ minutes $)$ before storage at $-80^{\circ} \mathrm{C}$. Cell pellets were resuspended in column binding buffer (20 $\mathrm{mM}$ sodium phosphate, $500 \mathrm{mM} \mathrm{NaCl}, 5 \mathrm{mM}$ imidazole, $\mathrm{pH}$ 7.4) and lysozyme was added to a final concentration of $0.2 \mathrm{mg} / \mathrm{ml}$. After $30 \mathrm{~min}$ incubation on ice, Triton-X100 (1\% v/v) was added to the lysis solution and DNAse and RNAse (10 mg/ml each) were added for $30 \mathrm{~min}$ to reduce the sample viscosity. Finally, the insoluble fraction of the samples was removed by centrifugation (20 $\mathrm{min}$ at $20,000 \mathrm{xg}$ ).

Before purifying rTTR by affinity chromatography, the sample was filtered through a 0.2 urn filter (Sarstedt). Immobilized metal $\left(\mathrm{Ni}^{2+}\right)$ affinity chromatography was conducted using His-Trap-FF crude Kit (1 ml column; GE Healthcare) equilibrated with elution buffer (20 mM sodium phosphate, $500 \mathrm{mM}$ $\mathrm{NaCl}, 20 \mathrm{mM}$ imidazole, $\mathrm{pH}$ 7.4). Lysate with recombinant protein was applied to the column and thereafter bound protein was eluted using a stepwise imidazole gradient with $100,200,250,300$ and $500 \mathrm{mM}$ imidazole. Aliquots of the eluates were collected and controlled by $12 \%$ SDS polyacrylamide gel electrophoresis (SDS-PAGE) and InVision ${ }^{\mathrm{TM}}$ His-tag In-gel staining (Invitrogen). For each of the liver and brain sourced herring and glaucous gull recombinant TTR, there were two bands (18 and $36 \mathrm{kDa}$ ), which eluted at approximately $300 \mathrm{mM}$ imidazole. 
The protein concentration of each purified rTTR was quantified using the Bradford method (Bradford 1976).

\subsubsection{Competitive rTTR Binding}

Competitive ligands, and $\mathrm{T} 4$ and $\mathrm{T}_{3}$ stock solutions were prepared at concentrations ranging from $10^{\prime 3}$ to $10^{5} \mathrm{nM}$. A stock solution of the purified $\mathrm{rTTR}$ protein $(5 \mathrm{nM})$ was prepared by dissolution in equal parts of $0.1 \mathrm{M}$ Tris- $\mathrm{HC} 1,0.1$ $\mathrm{mM} \mathrm{NaC1}$, and $1 \mathrm{mM}$ EDTA buffer with a $\mathrm{pH}$ 8. As a negative control solutions were prepared with DMSO/ethanol. For the assay volumes, the concentrations of rTTR and buffer were proportionally adapted from previous methods with minor modifications (Meerts et al 2000; Lans et al 1993). For the rTTR competitive binding assays, a volume of $10 \mathrm{ul}$ of stock concentrations $\left(10^{\prime 3}\right.$ to $\left.10^{5} \mathrm{nM}\right)$ was added to the assay incubation mixture, which had a final volume of 200 ul. For the stocks of concentrations ranging from $10^{\prime \prime 3}$ to $10^{\prime 1} \mathrm{M}$, a volume of $50 \mathrm{ul}$ was used for a final incubation volume of $1 \mathrm{ml}$.

The competitive binding assay was based on previous methods with minor modifications (Meerts et al 2000; Lans et al 1993). For each of the competitive ligand and DMSO control stock solutions, human TTR (30 nM) stock solution (using $3 \mathrm{nM}$ ) or gull TTR (equilibrated to $5 \mathrm{nM}$ from an original concentration of $0.77 \mathrm{mg} / \mathrm{ml})$ was incubated with a mixture with each of ${ }^{125} \mathrm{I}-\mathrm{T} 4(5 \mathrm{nM}, 7000 \mathrm{cpm})$ and unlabeled $\mathrm{T}_{4}(5 \mathrm{nM})$ in Tris- $\mathrm{HCl}$ buffer. The treatment was similar for ${ }^{125} \mathrm{I}-\mathrm{T}_{3}$ and unlabeled T3. The incubation mixtures were allowed to reach binding 
equilibrium overnight at $4^{\circ} \mathrm{C}$. After incubation, protein-bound and -free ${ }^{125} \mathrm{I}-\mathrm{TH}$ was separated by filtration. Protein-bound and - free ${ }^{125} \mathrm{I}-\mathrm{TH}$ was separated on a Biogel-P6DG column (bed volume: $1.2 \mathrm{ml}$; prepared in a 1-ml disposable syringe) that was equilibrated with 300 pi $10 \%$ (w/v) Tris-HCl buffer, and centrifuged for $20 \mathrm{~min}$ at $4,200 \times \mathrm{g}$ at room temperature. The columns were spin-forced (Jouan C412 centrifuge) again after an additional $200 \mathrm{~W}$ of Tris- $\mathrm{HCl}$ buffer was added. These first two eluant fractions, containing the protein bound ${ }^{125} \mathrm{I}-\mathrm{TH}$ fraction were combined, and the total radioactivity was counted and compared to the control incubations. Protein-bound ${ }^{125} \mathrm{I}-\mathrm{TH}$ was quantified in the fractions. Total ${ }^{125} \mathrm{I}$ radioactivity per assay $(0.75 \mathrm{KBq} /$ assay) was measured using a gamma counter (Cobra II Auto gamma). Protein-free ${ }^{125} \mathrm{I}-\mathrm{TH}$ remained bound to the Biogel matrix (P6DG), and therefore was not present in the first two eluant fractions.

\subsection{Albumin}

\subsubsection{Albumin Cloning and Sequencing}

The PCR primers were designed based on the nucleotide acid sequences found in chicken (Gallus gallus) using the PCR primer design service of Eurofins MWG Operon (Germany). Total RNA was purified from liver tissues using TRIzol® reagent according to the manufacturer's protocol. The quality of the RNA was determined by agarose gel electrophoresis. Total cDNA for the polymerase chain reaction (PCR) was generated from 1 ug total RNA using iScript cDNA Synthesis Kit with a combination of random and poly-T primers as described by the 
manufacturer (Bio-Rad Laboratories, Hercules, CA, USA). PCR program included an enzyme activation step at $95^{\circ} \mathrm{C}(5 \mathrm{~min})$ and 40 cycles of $95^{\circ} \mathrm{C}(1$ $\min ), 55^{\circ} \mathrm{C}(1 \mathrm{~min})$, and $72^{\circ} \mathrm{C}(1 \mathrm{~min})$. The single band obtained by PCR was cloned into pCR2.1 vector in an E. coli INVaF strain (Invitrogen), and the plasmids were sequenced at Eurofins MWG Operon (Ebersberg, Germany). The generated nucleotide sequences were confirmed using NCBls Basic Local Alignment Search Tool, BLASTx. (http://www.ncbi.nlm.nih.gov/BLAST) and translated into amino acid sequences using Expasy translation tool (http://us.expasy.Org/tools/\#translate). Since the investigated sequences of glaucous and herring gull were identical, the plasmids obtained from herring gull cDNA were used for the purification of albumin.

In order to investigate the similarity of gull albumin to the albumin of other vertebrates, amino acid sequences from chicken (Gallus gallus) human (Homo sapiens), rat (Rattus norvegicus), frog (Rana catesbeiana), gecko (Hemidactylus frenatus) and salmon (Salmo salar) were aligned using the Multiple Alignment Construction and Analysis Workbench (MACAW). Phylogenetic analysis of the albumin was performed using alignment and the neighbor-joining method (Saitou and Nei 1987) option of the Phylip program (Galtier et al 1996) with 100 bootstrap replicates. For the construction of the phylogenetic tree, the albuminlike protein sequence of $2 \mathrm{~S}$ seed storage protein 1 from Arabipdosis thaliana (Accession No. NM_118848) was used as an out-group as it has low homology to vertebrate albumin protein. 


\subsubsection{Expression and purification ofrecALB}

For albumin expression, the coding sequence were transferred from the pCR2.1 vector into $\mathrm{pET} 28 \mathrm{c}$, and the obtained plasmids were verified by sequencing and then expressed using the BL21 (RIPL) codon plus E. coli strain as expression host. E. coli was grown overnight in $3 \mathrm{ml}$ Lauria Bertani medium (LB-medium; 5 $\mathrm{g} / \mathrm{L} \mathrm{NaCl}, 5 \mathrm{~g} / \mathrm{l}$ Yeast extract and $10 \mathrm{~g} / \mathrm{l}$ Trypton) containing $50 \mathrm{ug} / \mathrm{ml}$ kanamycin and $34 \mathrm{ug} / \mathrm{ml}$ chloramphenicol. Details of cell growth and expression conditions are described in Ucan-Marin et al (2009). Before purification, the insoluble fraction of the samples was removed by centrifugation (20 $\min$ at $20,000 \times \mathrm{g}$ ) and the sample was filtered through a 0.2 urn filter (Sarstedt). Purification of albumin was performed using immobilized metal $\left(\mathrm{Ni}^{2+}\right)$ affinity chromatography in $1 \mathrm{ml}$ His-Trap-FF crude columns according to the manufacturer's recommendations (GE-Healthcare). Elution was optimized using 500 milliM imidazole buffer (20 milliM sodium phosphate, 500 milliM NaCl, 20 milliM imidazole, $\mathrm{pH}$ 7.4). Aliquots of the eluants were controlled by $12 \%$ SDS polyacrylamide gel electrophoresis (SDS-PAGE) and visualized by InVision ${ }^{\mathrm{TM}}$ His-tag In-gel staining (Invitrogen). The protein concentration of each purified recALB was quantified using the Bradford method (Bradford 1976).

\subsubsection{Substrate competitive binding with recALB}

Competitive ligand binding assays using gull and human recALB were the same as described previously for gull and human recTTR. The preparation of ligand 
treatment solutions was as previusly described with the exception that the stock solution of the purified gull recALB was $5 \mathrm{nM}$.

\subsection{Data analysis for Competitive Binding}

All TTR and Albumin competitive binding assays were carried out in triplicate, and the triplicate assay set was repeated on separate day, and showed that relative competitive binding results were reproducible. Mean relative competitive binding values were based on $n=6$ replicates (combined triplicates on two different days). Competitive binding curves for each ligand were made by plotting the relative ${ }^{125} \mathrm{I}-\mathrm{T} 4$ or ${ }^{125} \mathrm{I}-\mathrm{T}_{3}$ protein binding (\% of control) against the natural logarithm of the competitor concentration. Competitive binding curves were described by the sigmoidal function $\mathrm{y}=\mathrm{aO}+\mathrm{a} 1 /(1+\exp ((\mathrm{a} 2+\mathrm{x}) / \mathrm{a} 3))$ (SlideWrite plus 4.0, Advanced Graphics Software, Carlsbad, CA). The relative potency of the individual competitors was evaluated retrospectively. Using the T3 (or T4) as Relative Potency 1, the value was compared with the competitor ligands with T3 (or T4). Where $X$ (dose) and $Y$ (binding) are independent, the variance of $Y / X$ is $V(Y / X)=E\left[Y^{A} 2\right] V(1 / X)+V(Y) E[1 / X]^{A} 2(V=$ variance, $E=$ expected value). A single factor ANOVA with a Studentized Newman-Keuls (SNK) test was used to assess the statistical significance $(p<0.05)$ of the differences among competitive binding assays to validate the triplicate response of binding. Inhibitory constants were calculated according to Cheng and Prusoff (1973), where the affinity constant $K \backslash$ (also known as 150) $=K a(1+\mathrm{To} / \mathrm{Kd})$. The 150 
is the concentration of inhibitor resulting in $50 \%$ inhibition, the $\mathrm{Kd}$ is the dissociation constant of inhibitor-binder reaction, $\mathrm{Kd}^{*}$ is the dissociation constant of the tracer-binder reaction, and $T_{0}$ is the total added concentration of the tracer.

\subsection{Organohalogens}

\subsubsection{Extraction and Cleanup}

The extraction and clean up of plasma and liver for OC $(1,2,4,5$ tetrachlorobenzene, 1,2,3,4-tetrachlorobenzene, pentachlorobenzene, o> hexachlorocyclohexane, hexachlorobenzene, B-hexachlorocyclohexane, yhexachlorocyclohexane, octachlorostyrene, heptachlor epoxide, oxychlordane, tchlordane, c-chlordane, t-nonachlor, p,p'-DDE, dieldrin, p,p'-DDD, c-nonachlor, p,p'-DDT, photomirex, mirex, TCPM); PCB (PCB-16/32, 17, 18, 22, 28, 31, 33/20, $42,44,47 / 48,49,52,56 / 60,64 / 41,66,74,70 / 76,85,87,92,95,97,99,101 / 90$, $105,110,114,118,128,130,137,138141,146,149,151,153,156,157,158$, $167,170 / 190,171,172,174,176,177,178,179,180,183,187,189,194,195$, 196/203, 199, 200, 202, 206, 207, 208); PBDE (BDE-17, 28, 47, 49, 66, 85, 99, 100, 101, 138, 154/BB153. 153, HBCD, 183, 190, 209), $\mathrm{MeSO}_{2}$-CB (3$\mathrm{MeSO}_{2} \mathrm{CB} 52,3-\mathrm{MeSO}_{2} \mathrm{CB} 49,4-\mathrm{MeSO}_{2} \mathrm{CB} 52,4-\mathrm{MeSO}_{2} \mathrm{CB} 49,4-\mathrm{MeSO}_{2} \mathrm{CB} 64,3-$ $\mathrm{MeSO}_{2} \mathrm{CB} 70,3-\mathrm{MeSO}_{2} \mathrm{CB} 101,4-\mathrm{MeSO}_{2} \mathrm{CB} 70,4-\mathrm{MeSO}_{2} \mathrm{CB} 101, \mathrm{MeSO}_{2} \mathrm{DDE}, 3-$ $\mathrm{MeSO}_{2} \mathrm{CB} 110, \quad 3-\mathrm{MeSO}_{2} \mathrm{CB} 149, \quad 4-\mathrm{MeSO}_{2} \mathrm{CB} 110, \quad 4-\mathrm{MeSO}_{2} \mathrm{CB} 87, \quad 3-$ $\left.\mathrm{MeSO}_{2} \mathrm{CB} 132,4-\mathrm{MeSO}_{2} \mathrm{CB} 132,4-\mathrm{MeSO}_{2} \mathrm{CB} 174\right)$ and OH-PCB (4-OH-CB79, 4OH-CB97，4-OH-CB107/4，4-OH-CB108，2-OH-CB114，4-OH-CB120, 4-OHCB162, 4-OH-CB163, 4-OH-CB177, 4-OH-CB178, 3-OH-CB180, 3-OH-CB182, 
3-OH-CB183, 4-OH-CB184, 4-OH-CB187, 4-OH-CB193, 4-OH-CB198, 4-OHCB199, 4-OH-CB200, 4-OH-CB201，4-OH-CB202, 4,4'-diOH-CB202, 3-OHCB203, 4-OH-CB208), OH-PBDE (6-OH-BDE17, 4-OH-BDE17, 2-OH-BDE68, 6OH-BDE47, 3-OH-BDE47, 5-OH-BDE47, 4-OH-BDE49, 4-OH-BDE42, 6-OHBDE90，6-OH-BDE99，2-OH-BDE123，6-OH-BDE85，6-OH-BDE137), 4-OHheptachlorstyrene (4-OH-HpCS) and MeS02-DDE and were based on methods described widely in detail for blood and liver, with some modifications (Chu et al 2003; Gebbink et al 2008a, 2008b; McKinney et al 2006; Muir et al 2006; Montie et al 2009; Sandala et al 2004). Other BFRs including pentabromotoluene (PBT), hexabromobenzene (HBB), 2,2',4,4',5-pentabromobiphenyl (BB-101) and total(a)-hexabromocyclododecane (HBCD) were also measured according to recently published procedures (Gauthier et al 2009).

Briefly, approximately $2.0 \mathrm{~g}$ of liver and $1 \mathrm{ml}$ of plasma, were spiked with internal standards $\left[\mathrm{six}^{13} \mathrm{Ci}_{2}\right.$-labeled PCBs (CB-28, $-52,-118,-153,-180$, and -194), two PBDEs (BDE-30), 3-MeS02-2- $\mathrm{CH}_{3}-2^{\prime}, 3^{\prime}, 44^{\prime}, 5,5^{\prime}$-pentachlorobiphenyl, four ${ }^{13} \mathrm{Ci}_{2}$ labeled OH-PCBs (4'-OH-CB120, 4'-OH-CB159, 4'-OH-CB172, 4'-OH-CB187), and 2'-OH-BDE28] and extracted via liquid: liquid partitioning. The extraction and clean up of liver for OCs, PCBs, PBDEs, and $\mathrm{MeSO}_{2}-\mathrm{PCB}$ and $\mathrm{OH}$-containing compounds were based on procedures described for brain with some modifications (Gebbink et al 2008b). 
The quantification of OCs, PCBs, HO-PCBs, $\mathrm{MeSO}_{2}$-PCBs, HO-PBDEs, and the BFRs including PBDEs, PBT, HBB, BB-101 and HBCD using gas chromatography-mass spectrometry (GC-MS) with electron impact (EI) or electron capture negative ionization $(\mathrm{ECNI})$ detection was used to determine the various chlorinated and brominated contaminants, respectively, in the isolated chemical fractions. The quantification limit for the contaminants was routinely ca. $0.01 \mathrm{ng} / \mathrm{g}$ (lipid weight).

\subsubsection{Analysis and Quantification}

PCBs analyses were carried out as described previously by Gebbink et al, (2008a); briefly, on an Agilent 6890 gas chromatograph (GC) coupled to an Agilent 5973 mass selective detector (MSD), fitted with a DB-5 column (30 m, $0.25 \mathrm{~mm}$ ID, 0.25 urn film thickness, J\&W Scientific). The GC oven temperature program for PCB was as follows: $100^{\circ} \mathrm{C}(3 \mathrm{~min}), 20^{\circ} \mathrm{C} / \mathrm{min}$ to $180^{\circ} \mathrm{C}, 5^{\circ} \mathrm{C} / \mathrm{min}$ to $300^{\circ} \mathrm{C}$. The MS was set in El ionization mode, with the ionization voltage set at $70 \mathrm{eV}$. The source and quadrupole temperature were $230^{\circ} \mathrm{C}$ and $150{ }^{\circ} \mathrm{C}$, respectively. In SIM, the $[M]+$ and $[M+2]+$ were monitored for 51 PCB congeners. For MeS02-PCBs the oven temperature program was $100^{\circ} \mathrm{C}(3 \mathrm{~min})$, $20^{\circ} \mathrm{C} / \mathrm{min}$ to $220^{\circ} \mathrm{C}(1 \mathrm{~min}), 3^{\circ} \mathrm{C} / \mathrm{min}$ to $280^{\circ} \mathrm{C}(8 \mathrm{~min})$. The $\mathrm{MS}$ was set in the ECNI mode. The source and quadrupole temperature were $180^{\circ} \mathrm{C}$ and $150^{\circ} \mathrm{C}$, respectively. Methane was used as collision gas. Using SIM the [M]- and $[M+2]$ - ions were monitored for each chlorinated homologue group. 
For $\mathrm{OH}-\mathrm{PCBs}$ determination the oven ramping program was $80^{\circ} \mathrm{C}(1 \mathrm{~min})$, $10^{\circ} \mathrm{C} / \mathrm{min}$ to $250^{\circ} \mathrm{C}(5 \mathrm{~min}), 5^{\circ} \mathrm{C} / \mathrm{min}$ to $300^{\circ} \mathrm{C}(10 \mathrm{~min})$. The MS was set in the ECNI mode. The source and quadrupole temperature were $180^{\circ} \mathrm{C}$ and $150^{\circ} \mathrm{C}$, respectively. Methane was used as collision gas. In SIM the [M]-, [M+2]- and $[\mathrm{M}-15]-\{[\mathrm{M}-\mathrm{CH} 3]-\}$ ions of the MeO-containing derivatives of all $\mathrm{OH}-\mathrm{PCB}$ were monitored. The PBDEs were determined by GC-MS-ECNI fitted with a DB-5 ht column (15 m, $0.25 \mathrm{~mm}$ ID, 0.1 urn film thickness, J\&W Scientific). The temperature program was $100^{\circ} \mathrm{C}(2 \mathrm{~min}), 25^{\circ} \mathrm{C} / \mathrm{min}$ to $250^{\circ} \mathrm{C}, 1.5^{\circ} \mathrm{C} / \mathrm{min}$ to $260^{\circ} \mathrm{C}, 25^{\circ} \mathrm{C} / \mathrm{min}$ to $325^{\circ} \mathrm{C}(7 \mathrm{~min})$. The MS was set in ECNI mode. The source and quadrupole temperature were $150^{\circ} \mathrm{C}$ and $150^{\circ} \mathrm{C}$, respectively. Methane was used as collision gas. Using SIM, the isotopic bromine anions (m/z 79 and 81) were monitored.

\subsection{Perfluorinated Compounds}

\subsubsection{Sample Preparation for PFCs}

Individual herring gull livers $(n=10)$ were collected from Hamilton Harbour and Scotch Bonnet Island in 2004. The livers were stored at $-40^{\circ} \mathrm{C}$ at Environment Canada's National Wildlife Specimen Bank (EC-NWSB) before chemical analysis. The extraction and cleanup is described in detail by Gebbink et al, (2009) and Chu and Letcher (2009).

Briefly, of each liver, two sub samples of $0.2 \mathrm{~g}$; one sub-sample was spiked with labelled internal standards [PFBS (PFHxA $\left.-{ }^{13} \mathrm{C}_{2}\right)$, PFHxS $\left(\mathrm{PFH} \times \mathrm{S}^{-18} \mathrm{O}_{2}\right)$, PFOS 
(PFOS $-{ }^{13} \mathrm{C}_{4}$ ), PFDS (PFUA- ${ }^{13} \mathrm{C}_{2}$ ), PFOSA and N-Me-FOSA (d-N-Me-FOSA), PFHxA (PFHxA- ${ }^{13} \mathrm{C}_{2}$ ), PFHpA (PFHxS $-{ }^{18} \mathrm{O}_{2}$ ), PFOA (PFOA $-{ }^{13} \mathrm{C}_{4}$ ), PFNA (PFNA${ }^{13} \mathrm{C}_{5}$ ), PFDA (PFDA- ${ }^{13} \mathrm{C}_{2}$ ), PFUnA (FUA $\left.-{ }^{13} \mathrm{C}_{2}\right)$. PFDoA, PFTriA, PFTeA and PFPA (PFDoA- ${ }^{13} \mathrm{C}_{2}$ ). For 6:2 FTUCA (6:2 FTUCA $-{ }^{13} \mathrm{C}_{2}$ ), 8:2 FTUCA (8:2 FTUCA$\left.{ }^{13} \mathrm{C}_{2}\right)$, 10:2 FTUCA (10:2 FTUCA $\left.-{ }^{13} \mathrm{C}_{2}\right)$. For 6:2 FTOH $\left(6: 2 \mathrm{FTOH}^{-13} \mathrm{C}_{2}\right), 8: 2$ FTOH (8:2 FTOH- $\left.{ }^{13} \mathrm{C}_{2}\right)$ and 10:2 FTOH (10:2 $\left.\left.\mathrm{FTOH}_{-}{ }^{13} \mathrm{C}_{2}\right)\right]$, used for PFC quantitation. The other sub-sample was not spiked with IS, and was used as a complex mixture (neutral and acidic fractions) in a competitive binding assay, the sub-samples were extracted with $10 \mathrm{mM} \mathrm{KOH}$ acetonitrile/water (80/20 v/v). Mainly carbon, but also deuterated and oxygen enriched isotope standards were used as specific internal standards (see Gebbink et al, 2009). A volume of $2 \mathrm{ml}$ of the extract was diluted with $8 \mathrm{ml}$ water and adjusted to $\mathrm{pH} 4$ with $2 \%$ aqueous formic acid. The cleanup and fractionation of the overall PFC extract was performed using Waters Oasis WAX cartridges. The cartridges were preconditioned with $3 \mathrm{ml}$ methanol followed by $3 \mathrm{ml}$ of water. The sample was loaded onto the cartridge, washed with $2 \%$ aqueous formic acid and then with water. The first fraction was collected by using $1 \mathrm{ml}$ methanol; the fraction contained the neutral PFCs, FTOHs and the FOSAs. The cartridge was washed with methanol before the second fraction was eluted using a solution of $1 \%$ ammonium hydroxide in methanol. This fraction contained the acidic PFCs; PFSAs, PFCAs and the FTUCAs. A volume of $0.5 \mathrm{ml}$ of fraction 1 was mixed with $20 \mathrm{mg}$ of active carbon. Fraction 2 was dried using a stream of nitrogen and 
dissolved in 200 |jl of methanol. Prior to LC-MS/MS analysis, both fractions were filtered using centrifugal filters (modified nylon 0.2 urn, 500 pi).

\subsubsection{Instrumental Analysis}

The separation of the target compounds in both fractions was carried out on a Waters 2695 HPLC equipped with an ACE 3 C-18 analytical column (50 mm x 2.1 mm I.D., 3pm particle size) and an ACE $3 \mathrm{C}_{18}$ guard column $(10 \mathrm{~mm} \times 2.1 \mathrm{~mm}$ I.D., 3pm particle size, Advanced Chromatography Technologies, Aberdeen, UK). The mobile phases for fraction 1 were water and methanol; for fraction 2, $2 \mathrm{mM}$ ammonium acetate in water and methanol were used (Mobile phase gradients are provided Tables S2 and S3). The flow rate was $0.2 \mathrm{ml} / \mathrm{min}$ and the LC column was kept at $40^{\circ} \mathrm{C}$. Coupled to the HPLC was a Waters Quattro Ultima triple quadrupole mass spectrometer (Waters, Milford, MA, USA). Nitrogen was used as nebulizing gas and dissolvent gas, argon was used as collision gas when multiple reaction monitoring (MRM) mode was used. For neutral PFCs in fraction 1 atmospheric pressure, photoionization (APPI) was used in negative mode with krypton UV lamp (Chu and Letcher, 2008). Toluene was used a dopant and introduced to the APPI source at $2 \%$ of the flow rate of the mobile phase. The source temperature was $150^{\circ} \mathrm{C}$, the probe temperature $250^{\circ} \mathrm{C}$. Electrospray ionization (ESI) source in negative mode was used for acidic PFCs in fraction 2, with a source temperature of $120^{\circ} \mathrm{C}$ and a desolvation temperature of $350^{\circ} \mathrm{C}$. 


\subsection{References}

Bradford M, 1976. A rapid and sensitive method for the quantitation of microgram quantities of protein utilizing the principle of protein-dye binding. Anal Biochem 72: $248-254$.

Cheng Y, Prusoff WH, 1973. Relationship between inhibition constant $(K\{)$ and concentration of inhibitor which causes 50 per cent inhibition $\left({ }_{5} \mathrm{O}\right)$ of an enzymatic-reaction. Biochem Pharmacol 22: 3099-3108.

Chu S, Covaci A, Jacobs W, Haraguchi K, Schepens P, 2003. Distribution of methyl sulfone metabolites and polychlorinated biphenyls and $p, p^{\prime}-D D E$ in human tissues. Environ Health Perspect 111: 1222-1227.

Chu S, Letcher RJ, 2008. Analysis of fluorotelomer alcohols and perfluorinated sulfonamides in biotic samples by liquid chromatography-atmospheric pressure photoionization mass spectrometry. Journal of chromatography A 1215(1-2): 929.

Galtier N, Gouy M, Gautier C, 1996. SEAVIEW and PHYLO_WIN: Two graphic tools for sequence alignment and molecular phylogeny. Comput Appl Biosci 12: 543-548.

Gauthier LT, Potter D, Hebert CE, Letcher RJ, 2009. Temporal trends and spatial distribution of non-polybrominated diphenyl ether flame retardants in the eggs of colonial populations of Great Lakes herring gulls. Environ Sci Technol 43(2): 312317.

Gebbink WA, Sonne C, Dietz R, Kirkegaard M, Riget FF, Born EW, Muir DCG, Letcher RJ, 2008a.Tissue-specific congener composition of organohalogen and metabolite contaminants in East Greenland polar bears \{Ursus maritimus), Environ Poll 152: 621-629.

Gebbink WA, Sonne C, Dietz R, Kirkegaard M, Born EW, Muir DCG, Letcher RJ, 2008b. Target tissue selectivity and burdens of diverse classes of brominated and chlorinated contaminants in polar bears (Ursus maritimus) from East Greenland. Environmental Science and Technology 42 :752-759.

Gebbink WA, Hebert C, Letcher RJ, 2009. Perfluorinated Carboxylates and Sulfonates and Precursor Compounds in Herring Gull Eggs from Colonies Spanning the Laurentian Great Lakes of North America. Environ Sci Technol 43: 7443-7449. 
Lans MC, Klasson-Wehler E, Willemsen M, Meussen E, Safe S, Brouwer A, 1993. Structure- dependent, competitive interaction of hydroxypolychlorobiphenyls, -dibenzo-p-dioxins and dibenzofurans with human transthyretin. Chem.-Biol Interact 88: 7-21.

Meerts IATM, van Zanden JJ, Luijks EAC, van Leeuwen-Bol I, Marsh G, Jakobsson E, Bergman A, Brouwer A, 2000. Potent Competitive Interactions of Some Brominated Flame Retardants and Related Compounds with Human Transthyretin in Vitro. Toxicological Sciences 56: 95-104.

McKinney MA, De Guise S, Martineau D, Beland P, Lebeuf M, Letcher RJ, 2006. Organohalogen contaminants and metabolites in beluga whale (Delphinapterus leucas) liver from two Canadian populations. Environ Toxi and Chem 25: 30-41.

Mineau P, Fox GA, Norstrom RJ, Weseloh DV, Hallett DJ, Ellenton JA, 1984. Using the herring gull to monitor levels and effects of organochlorine contamination in the Canadian Great Lakes. In Toxic Contaminants in the Great Lakes (J.O. Nriagu and M.S. Simmons, Eds.), pp. 425-452. John Wiley \& Sons, New York.

Montie EW, Reddy CM, Gebbink WA, Touhey KE, Hahn ME, Letcher RJ, 2009. Organohalogen contaminants and metabolites in cerebrospinal fluid and cerebellum gray matter in short-beaked common dolphins and Atlantic whitesided dolphins from the western North Atlantic. Environ Poll 157(8-9): 2345-2358.

Muir DCG, Backus SM, Derocher AE, Dietz R, Evans T, Gabrielsen GW, Nagy J, Norstrom RJ, Sonne C, Stirling I, Taylor MK, Letcher RJ, 2006. Brominated flame retardants in polar bears (Ursus maritimus) from Alaska, the Canadian Arctic, Greenland, and Svalbard. Environ Sci and Tech 40: 449-455.

Saitou N, Nei M, 1987. The neighbor-joining method: A new method for reconstructing phylogenetic trees. Mol. Biol. Evol. 4: 406-425.

Sandala GM, Sonne-Hansen C, Dietz R, Muir DCG, Valters K, Bennett ER, 2004. Born, E. W.; Letcher, R. J. Hydroxylated and methyl sulfone PCB metabolites in adipose and whole blood of polar bears (Ursus maritimus) from East Greenland. Sci Total Environ 331: 125-141.

Verreault J, Skaare JU, Jenssen BM, Gabrielsen GW, 2004. Effects of Organochlorine Contaminants on Thyroid Hormone Levels in Arctic Breeding Glaucous Gulls, Larus hyperboreus. Environ Health Perspect 112(5): 532-537.

Verreault J, Gabrielsen GW, Chu S, Muir DCG, Andersen M, Hamaed A, Letcher RJ, 2005a. Flame Retardants and Methoxylated and Hydroxylated PBDEs in Two Norwegian Arctic Top-Predators: Glaucous Gulls and Polar Bears. Environ Sci Technol 39: 6021-6028. 
Verreault, J, Letcher RJ, Muir DCG, Chu S, Gebbink WA, Gabrielsen GW, 2005b. New organochlorine contaminants and metabolites in plasma and eggs of glaucous gulls (Larus hyperboreus) from the Norwegian Arctic. Environ Toxicol Chem 2005b 24(10): 2486-2499. 


\section{CHAPTER THREE ${ }^{1}$}

\section{Recombinant Transthyretin Purification and Competitive Binding with \\ Organohalogen compounds in Two Gull Species (Larus argentatus and}

Larus hyperboreus)

\subsection{Abstract}

Glaucous gulls from Norway and herring gulls from Great Lakes of North America are differentially exposed to chlorinated and brominated contaminants that can perturb thyroid hormone-dependent processes. Environmentally relevant concentrations of selected polychlorinated biphenyl (PCB) and polybrominated diphenyl ether (PBDE) flame retardant congeners and their hydroxylated $(\mathrm{OH})$ and methoxylated ( $\mathrm{MeO}$ ) analogues were analyzed with competitive assays, to assess their binding affinity with thyroxine (T4) and 3,5,3'-triiodothyronine $\left(T_{3}\right)$ thyroid hormones (THs) on the recombinant albumin and transthyretin transport proteins of humans and gulls. We isolated, cloned, sequenced, purified and expressed the complementary DNA (cDNA) of albumin from liver of herring and glaucous gull. Concentration-dependent, competitive binding curves were generated for T4 and T3 binding alone and for selected substrates using gull and human recombinant albumin (recALB). Albumin amino acid sequences were identical for both gull species, and in phylogenetic comparisons, was $\sim 70 \%$

\footnotetext{
1 This chapter is based on a published paper in a peer-reviewed journal. "Ucan-Marin, F, Arukwe A, Mortensen A, Gabrielsen GW, Fox GA, Letcher RJ, 2009. Recombinant transthyretin purification and competitive binding with organohalogen compounds in two gull species (Larus argentatus and Larus hyperboreus). Toxicol. Sci. 107: 440-450.".
} 
similar to human sequence. Human recALB had high preference for $T_{4}$ relative to T3 whereas it was reversed for gull recALB. Binding assays with recALB and recTTR gull proteins showed that relative to $2,2^{\prime}, 4,4^{\prime}$-tetrabromoDE (BDE47) and 2,2',3,4',5,5',6-heptaCB (CB187) and the MeO-substituted (4-MeO-CB187 and 6MeO-BDE47) analogues, 4-OH-CB187, 6-OH-BDE47 and 4'-OH-BDE49 had greater affinity than $\mathrm{T} 3$ or $\mathrm{T}_{4}$. These results indicate that xenobiotic ligand binding to human albumin or TTR cannot be used as a surrogate for gull binding interactions. The combination of TH-like brominated diphenyl ether backbone (relative to the chlorinated biphenyl backbone), and the presence of $\mathrm{OH}$-group produced a more effective competitive ligand on human and gull recALB and recTTR relative to both $\mathrm{T} 3$ and $\mathrm{T}_{4}$. This suggests the possibility that $\mathrm{OH}$ substituted organohalogen contaminants may be exposure concern to the thyroid system in free-ranging gulls as well as for humans. 


\subsection{Introduction}

Transthyretin (TTR), albumin (ALB) and thyroid binding globulin (TBG) are the major hormone transport proteins of thyroid hormones (THs) in all vertebrates (McKinnon et al., 2005). These transport proteins bind to THs, and specifically 3,5,3-triidothyronine (T3) and thyroxine $\left(T_{4}\right)$, and circulate in the blood. In vertebrates, the three thyroid hormone carrier proteins are synthesized by the liver, but only TTR is synthesized in the brain (Dickson et al 1987). Among vertebrate species, there are differences in the relative importance of circulating levels of TTR, ALB and TBG. In avian species, the study of TTR has been mainly in the context of comparative evolution relative to other taxa (Power et al 2002; Richardson et al 1994). In contrast to humans, it has been shown that TTRs from teleost fish (Yamauchi et al 1999), amphibians (Prapunpoj et al 2000; Yamauchi et al 1998), reptiles (Prapunpoj et al 2002), and birds (Chang et al 1999) bind $T_{3}$ with higher affinity than $\mathrm{T} 4$.

In birds, two main groups of hormones are involved in the growth of birds, growth hormones (GHs) together with the associated insulin-like growth factors (IGFs), and the T4 and T3. Normal growth of post-hatching birds requires GHs, T4 and $T_{3}$ (Decuypere et al 2005). THs have been reported to regulate thermogenesis in vertebrates, especially basal metabolic rate and cold-induced thermogenesis (Silva 1995). Therefore, circulating TH levels can be perturbed by temperature stress. For example, Kuhn and Nouwen (1978) reported that in domestic fowl 
(Rhode Island Red strain), a gradual decline in ambient temperature from 26.5 to $17.5^{\circ} \mathrm{C}$ elevated serum $T_{3}$ in 40 -day-old chicks. Increases in $T_{4}$ occurred when the temperature was lowered further to $12.5^{\circ} \mathrm{C}$. Physiological processes perturb circulating $\mathrm{TH}$ levels and $\mathrm{TH}$-dependent processes. THs are very lipophilic molecules, and in the absence of TH distributor proteins (THDPs), they interact as carriers from serum into lipid membranes (Ekins 1990). The effect of THs on protein and lipid metabolism is a biphasic nature: in low physiological concentrations, they are anabolic while at higher concentrations they are catabolic (Decuypere et al 2005).

A major concern is that $\mathrm{TH}$-dependent processes, such as $\mathrm{TH}$ transport, are susceptible to chemical stress and can be disrupted by thyroidogenic, xenobiotic compounds accumulated in an organism (Ishihara et al 2003a; 2003b). Such chemical stressors include polychlorinated biphenyl (PCB) and polybrominated diphenyl ether (PBDE) flame retardant congeners as well as hydroxylated $(\mathrm{OH})$ analogues such as $\mathrm{OH}$-PCBs and OH-PBDEs. The metabolism of PCBs and particularly PBDE flame-retardants are not well understood in wildlife and particularly in birds (Hakk and Letcher 2003). However, putative OH-PCB and OH-PBDE metabolites have been reported in the tissues of certain avian species. Several OH-PCB and OH-PBDE congeners, and to a much lesser extent methoxylated (MeO)-PBDEs, were recently quantified in the plasma of adult glaucous gulls (Larus hyperboreus) from the Norwegian Arctic (Verreault et al 2005a; 2005b), and the plasma of bald eaglets (Haliaeetus leucocephalus) 
from the west coast of North America (McKinney et al 2006). In the plasma of Norwegian glaucous gulls, 2,2',4,4'-tetrabromo diphenyl ether (BDE-47), 6-OHBDE47, 4'-OH-2,2',4',5-tetrabromo diphenyl ether (4'-OH-BDE49), 3,-MeOBDE47, 4'-MeO-BDE49, and most important among the OH-PCBs, 4-OH$2,2^{\prime}, 3,4^{\prime}, 5,5^{\prime}, 6$-heptachloro biphenyl (4-OH-CB187), tend to dominate. The presence of $\mathrm{OH}-\mathrm{PCBs}$ in the plasma of birds and other wildlife is more than likely due to oxidative cytochrome P450 (CYP)-mediated PCB biotransformation. However, both MeO-PBDEs and some OH-PBDE congeners can also bioaccumulate in aquatic food webs as natural products produced by marine organisms such as sponges and algae (Malmvarn et al 2005).

Thyroid system disrupting chemicals may target any of the multiple pathways in a chemical-dependent manner, including TH production, receptor binding, metabolism and interaction with transport proteins such as TTR (Ulrich 2003). Thyroidogenic activity via interaction with human TTR has been reported for such organohalogen contaminants such as congeners of PCBs, PBDE flame retardants, $\mathrm{OH}-\mathrm{PCB}$ and/or OH-PBDEs. Several PCB, PBDE, OH-PCB and/or OH-PBDE congeners have been shown to competitively displace T4 from human TTR, which consequently can result in the release of (free) T4, which can enhance T4 metabolism and excretion (Brouwer et al 1998; Meerts et al 2000; Purkey et al 2004). Neurological effects of PCBs and PBDEs have been reported in mammals, and may be partly explained by the ability of these compounds (or their metabolites) to decrease $\mathrm{TH}$ levels during a sensitive time 
periods, e.g. of neurodevelopment (Zoeller et al 2002; Costa and Giordano 2007). Regardless from natural source accumulation via metabolism of PBDEs, thyroidogenic and estrogenic dysfunction have been also reported in laboratory rats exposed to OH-PBDEs (Meerts et al 2000, 2001).

To my knowledge, the binding affinity of natural $T_{4}$ and $T_{3}$ ligands to avian TTR transport protein has not been reported, and especially the affinity to anthropogenic contaminants and/or metabolite ligands such as $\mathrm{OH}-\mathrm{PCBs}$ and $\mathrm{OH}$-PBDEs. In the present study, brain and liver tissues of two gull species from the genus Larus, glaucous gull from the Norwegian Arctic and herring gull from the Laurentian Great Lakes of North America were used to isolate TTR cDNA. Isolated TTR cDNA were cloned and sequenced. The recombinant TTR were expressed and purified, then the recombinant TTR protein was expressed and the product used in a competitive binding determination assays. Comparisons were performed on $\mathrm{T}_{3}, \mathrm{~T}_{4}$ with selected $\mathrm{PCB}, \mathrm{PBDE}, \mathrm{OH}-\mathrm{PCB}, \mathrm{OH}-\mathrm{PBDE}$ and analogous MeO-containing congeners previously reported and known for their environmental importance in the plasma of birds.

\subsection{Results and Discussion}

\subsubsection{Cloning and characterization of gull recombinant TTR}

The isolated TTR cDNA from brain and liver tissues of herring and glaucous gull were sequenced in both directions and sequence analysis showed identical nucleotide sequences between the species and between liver and brain. High 
conservation in aminoacid sequence was expected for the two gulls from the same genus, however divergence was also speculated due to their different ecosystem habits; depending in seawater and freshwater. The feeding patterns and metabolism was considered as a main factor for a probable different homeostasis and consequently differences in $\mathrm{TH}$ transport proteins nucleotide constitutence. However, TTR was a much conserved protein, and confirm his use as a protein to observe evolution in vertebrates.

The achieved nucleotide sequence was translated and the deduced gull TTR translation showed 126 amino acid residues with a calculated molecular mass of 13.8 kiloDalton $(\mathrm{kDa})$ (mass without his-tag labeling) and a theoretical isoelectric point (pi) of 5.1. A multiple alignment analysis was performed using the gull, duck, chicken, crocodile, human, rat, frog and zebra fish TTR variant (Figure 6) (Schuler et al 1991). The alignment showed that TTR is highly conserved among vertebrate species, but the $\mathrm{N}$-terminal region presented a low sequence homology. To define the relationship of gull rTTR (where the common "gull" rTTR from liver and brain is referred to as gullTTR) to TTRs from other vertebrate species, a phylogenetic tree was constructed using the neighbour-joining method and bootstrapped 100 times. This tree clearly grouped the gull rTTR with avian (chicken and duck) TTR variants (Figure 7). 

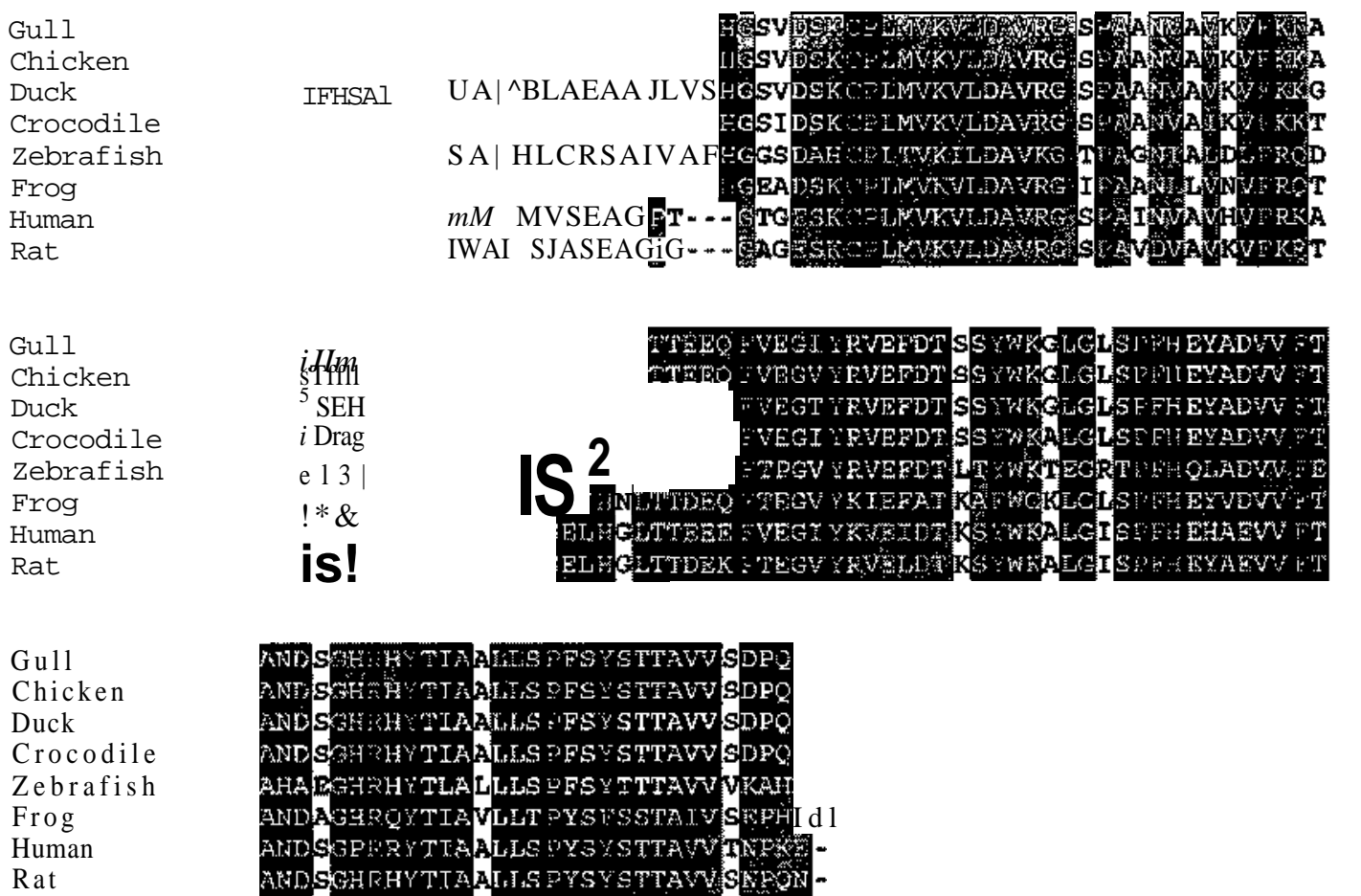
35
59 59 59

Figure 6. A multiple alignment of the predicted gull rTTR translation with TTRs from chicken, duck, crocodile, zebrafish, frog, human and rat was generated using MACAW. Identical and similar residues are indicated, darker shade corresponds to the most similar and no shade denotes any sequence homology. Accession numbers are: crocodile (CAA11129), frog (NP001081349), zebrafish (AAH81488), human (NP000362), rat (NP036813), chicken (NP990666), duck (ABC65926) and gull (sequence reported herein; EU352211). 
Figure 7. Phylogenetic analysis of the amino acid sequences of TTR from several vertebrate species and Campylobacter coli. The tree was constructed using the neighbour-joining method and bootstrap values from 100 replicates. The sequence accession numbers of analysed genes are: Crocodile (CAA11129), frog (NP001081349), Zebrafish (AAH81488), human (NP000362), rat (NP036813), Chicken (NP990666), duck (ABC65926) and gull (EU352211). 


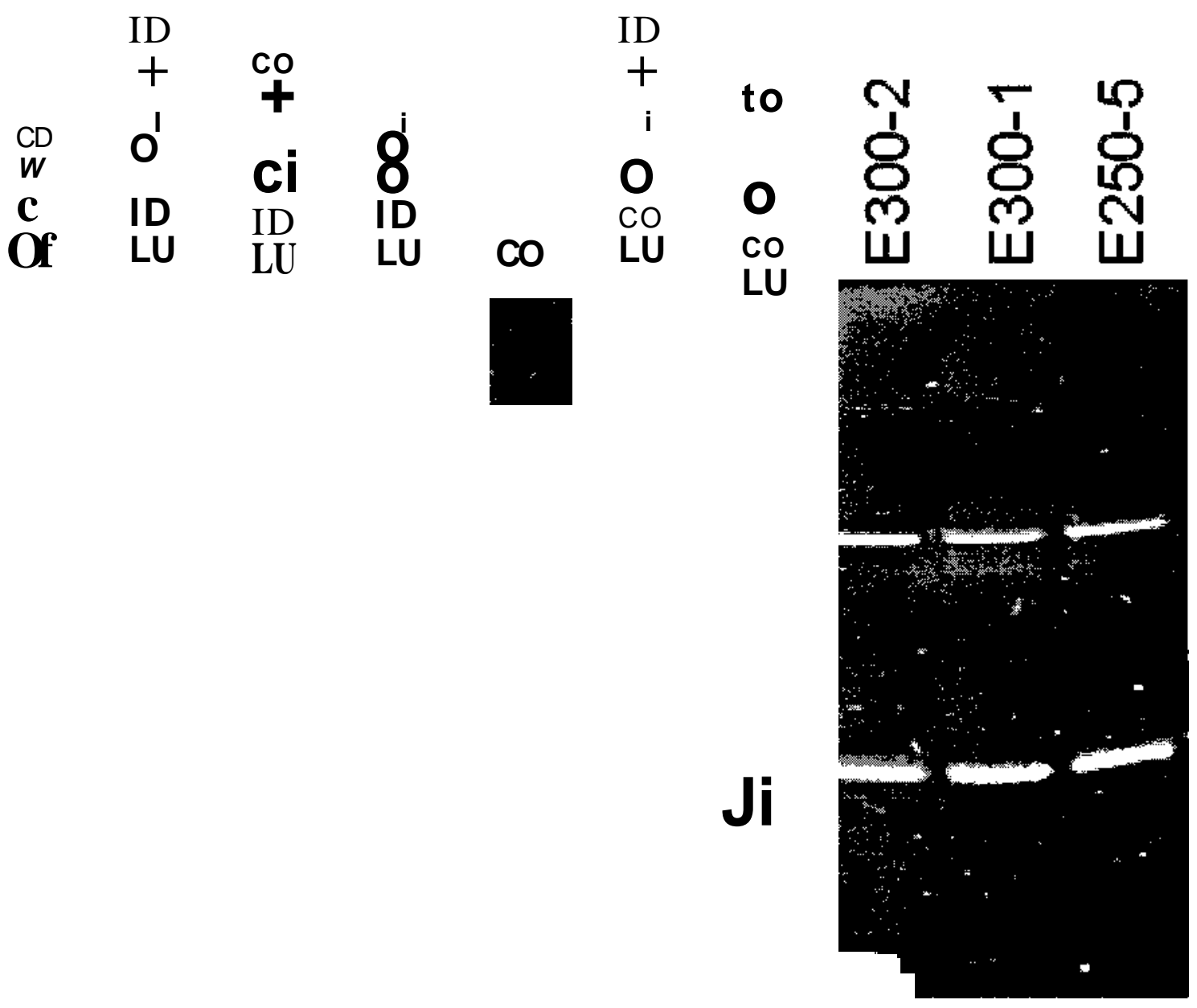

Figure 8. Purification of gull recombinant TTR ( $r T T R$ ) expressed in E.coli BL21RIPL. The electrophoretic gel shows eluants from a step-wise imidazole gradient with (from left to right) 250, 300 and $500 \mathrm{mM}$ imidazole concentrations, and the his-tag labelled gull rTTR protein is observed as a monomer of $18 \mathrm{kDa}$ and homodimer of $36 \mathrm{kDa}$ that is comprised of the two-monomer forms. 
Avian TTR is more similar to crocodile TTR than those from human, rat, frog or zebrafish. After transfection of the E.coli expression host, rTTR was expressed and purified using affinity column chromatography. SDS-PAGE analysis was performed to determine the expression of gull rTTR in the E.coli expression host (Figure 8). Gel analysis of the eluates showed a step-wise imidazole gradient with $100,200,250,300$ and $500 \mathrm{mM}$ and the his-tag labelled gull rTTR protein was observed as a protein monomer of $18 \mathrm{kDa}$ and homodimer of $36 \mathrm{kDa}$ that putatively comprises of the two protein monomers (Figure 8). Eluates containing $>250 \mathrm{mM}$ imidazole contained rTTR of high purity and were used for competitive binding assays.

\subsubsection{Competitive TTR binding assays}

Competitive $\mathrm{T} 3$ and $\mathrm{T}_{4}$ binding assays with the selected exogenous contaminant ligands were performed with purified human and/or gullTTR (Figure 9, Table 1 and 2), and showed that both $\mathrm{T}_{3}$ and $\mathrm{T} 4$ more competitively bind for gullTTR relative to human TTR. Concentration-dependent competitive binding curves were generated for the natural ligands $\mathrm{T} 3$ and $\mathrm{T} 4$, and comparatively for the exogenous ligands under study (Figure 10 and 11, Table 1 and 2). As shown in Figure 10, in comparison to CB187 and 4-MeO-CB187, 4-OH-CB187 was the most potent as a competitive ligand for the displacement of both T3 and T4, which were comparatively displaced by $4-\mathrm{OH}-\mathrm{CB} 187$. As shown in Figure 11, in comparison to BDE47 and 6-MeO-BDE47, 6-OH-BDE47 and 4'-OH-BDE49 was comparatively more potent in the competitive displacement of $\mathrm{T}_{3}$ and $\mathrm{T} 4$. 


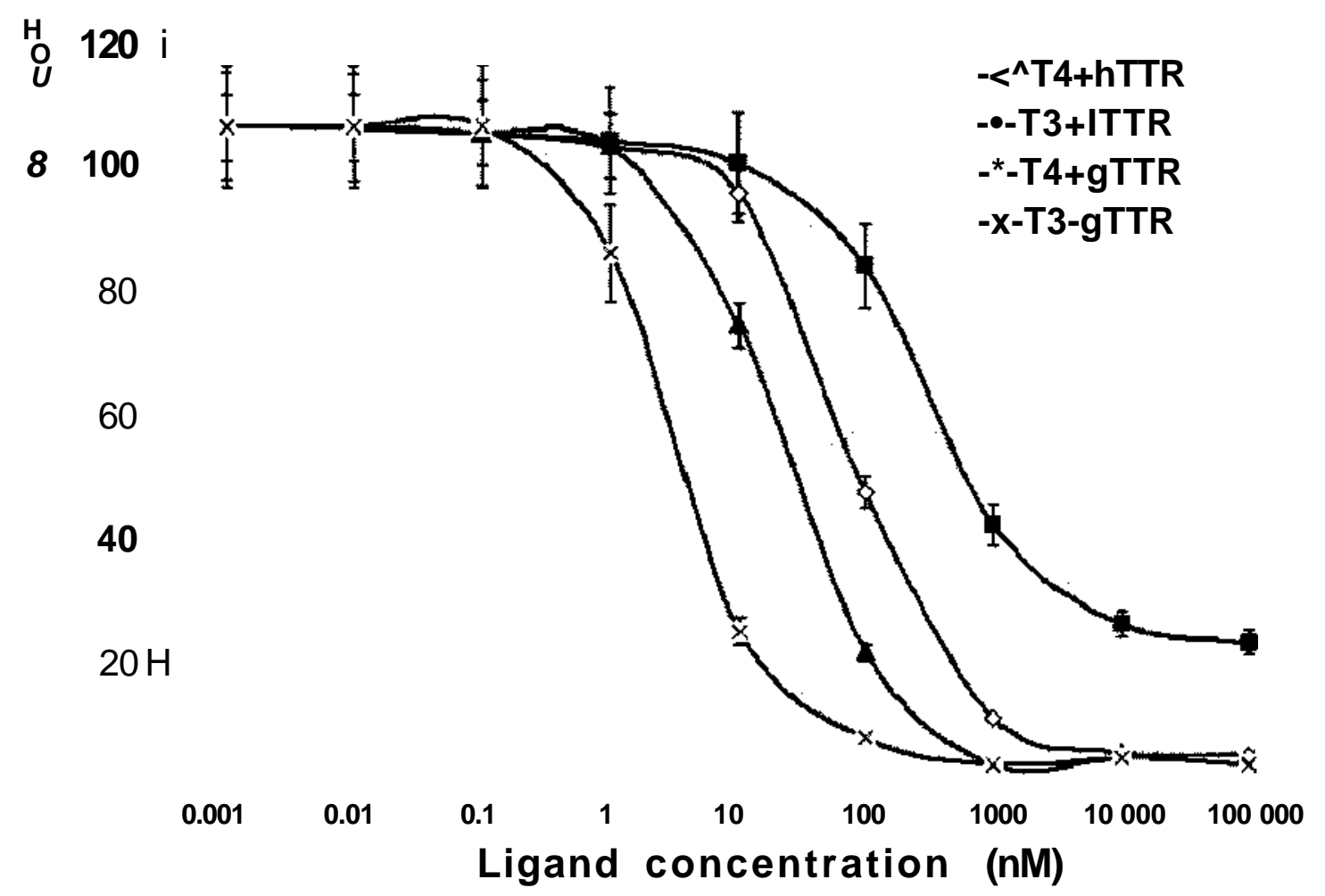

Figure 9. Concentration-dependent, competitive binding curves of gull transthyretin (gTTR) and commercially available human transthyretin (hTTR) with $T_{3}$ or $T_{4}$. The error bars denote the standard deviation of $n=6$ replicated (two $n=3$ replicate sets performed on different days). 
120

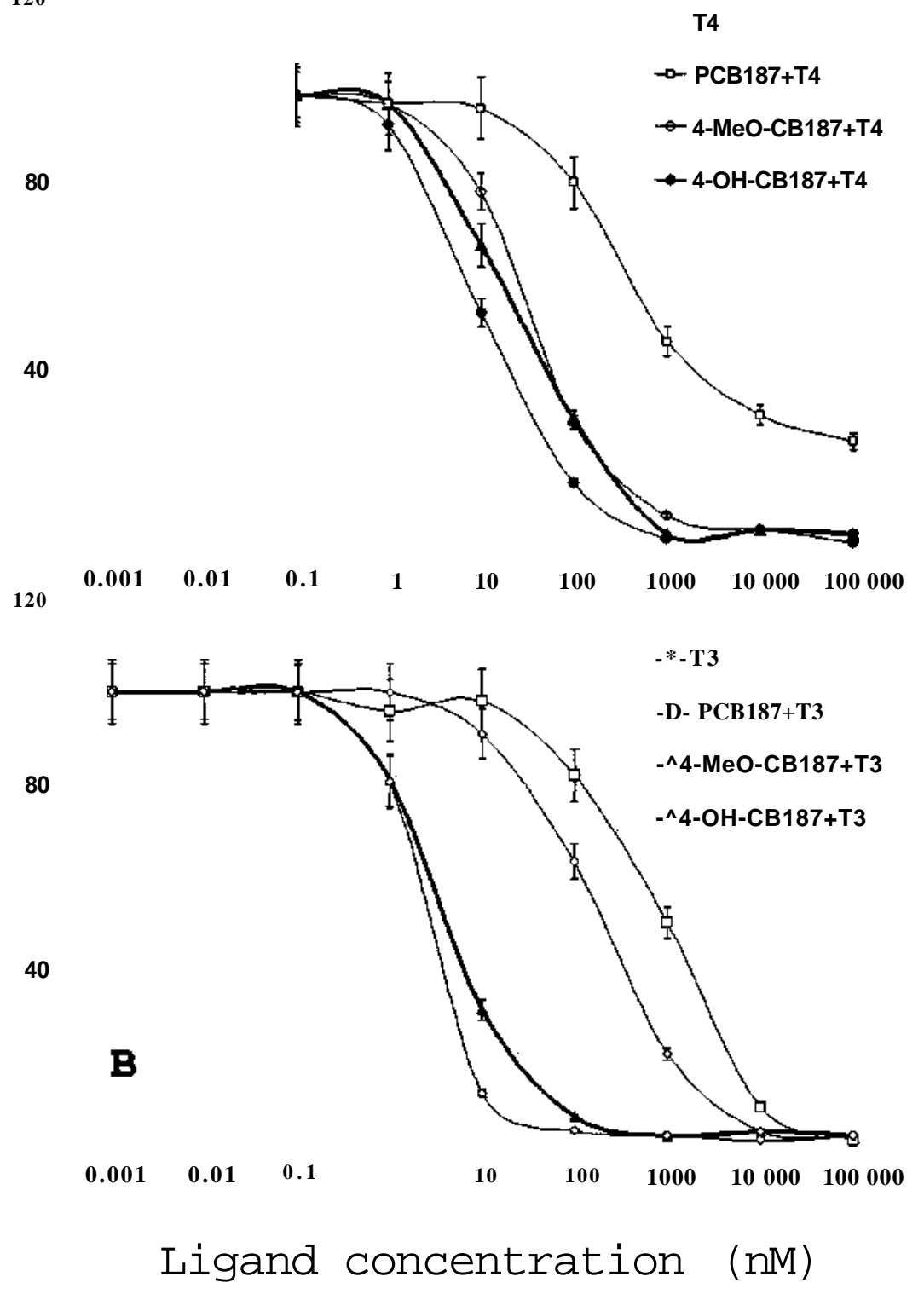

Figure 10. Concentration-dependent, competitive binding curves of $(A) T 4$ and (B) $T_{3}$ displacement from gull transthyretin by 2,2',3,4',5,5',6-heptaCB (CB-187), 4-hydroxy-CB187 (4-OH-CB187) or 4-methoxy-CB187 (4-MeO-CB187). The competitive binding parameters are listed in Table 1 . The error bars denote the standard deviation of $n=6$ replicated (two $n=3$ replicate sets performed on different days). 


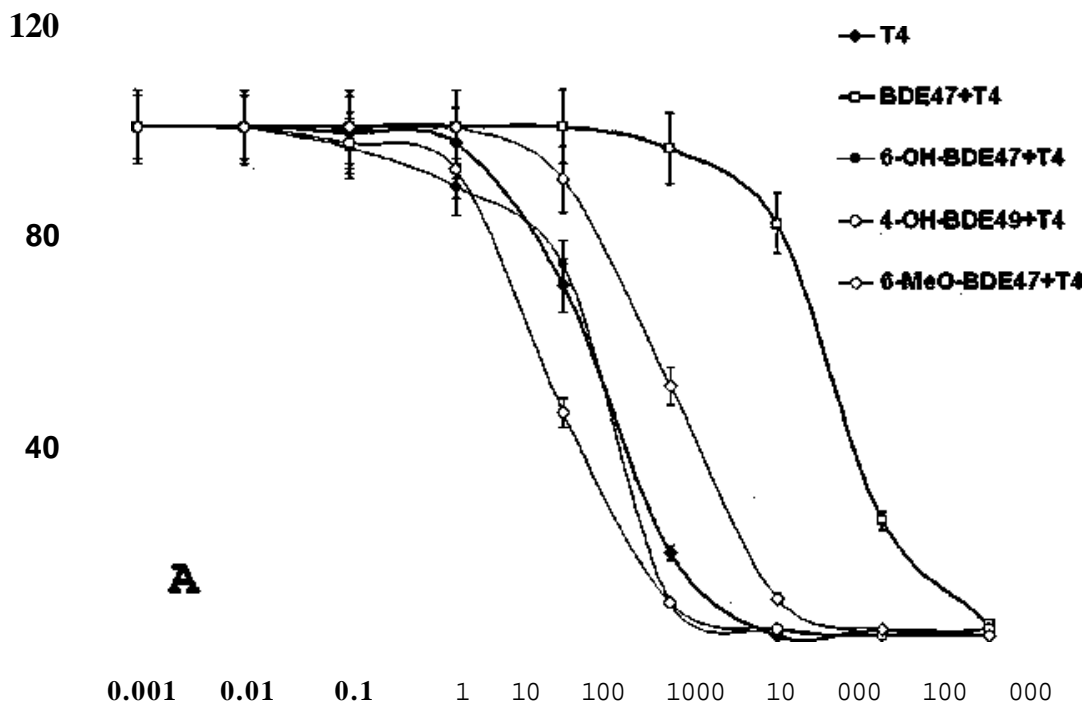

120

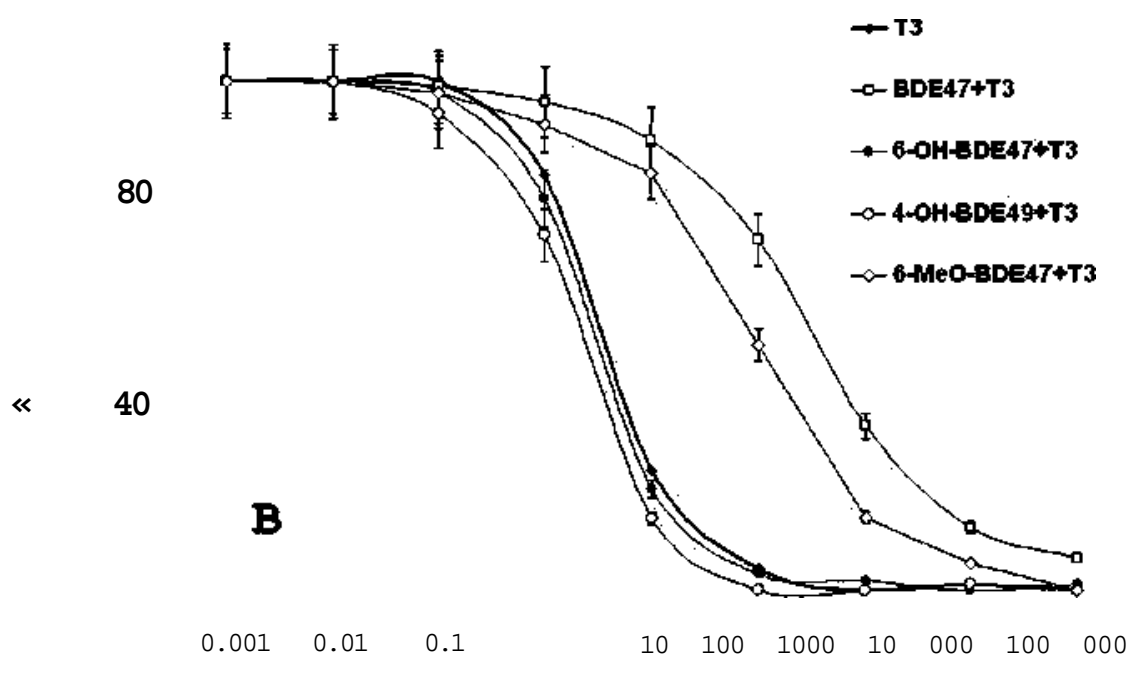

Ligand concentration (nM)

Figure 11. Concentration-dependent, competitive binding curves of (A) T4 and (B) T3 displacement from gull transthyretin by 2,2',4,4'-tetrabromoDE (BDE-47) flame retardant and 6-hydroxy-BDE47 (6-OH-BDE47), 6-methoxy-BDE47 (6MeO-BDE47) or 4-OH-2,2'4,5-tetrabromoDE (4-OH-BDE49). The competitive binding parameters are listed in Table 2. The error bars denote the standard deviation of $n=6$ replicated (two $n=3$ replicate sets performed on different days). 
Table 1. Competitive binding parameters for gull transthyretin protein and $T_{3}$ or T4 in the presence of model PCB and structural analogue congener ligands, and human TTR values for T3 and $\mathrm{T}_{4}$ as reference.

\begin{tabular}{|l|l|l|l|l|}
\hline Compound & $\mathrm{K}(\mathrm{nM})^{\mathrm{a}}$ & $\begin{array}{l}\text { Relative potency } \\
\mathbf{b}\end{array}$ & $\mathbf{K d}^{\mathrm{c}}$ & $\begin{array}{l}\text { Maximum \% } \\
\text { competition }^{\mathrm{d}}\end{array}$ \\
\hline $\mathrm{T}_{3}$ & 4.48 & 1 & 13.1 & $87 \pm 4.3$ \\
\hline $\mathrm{CB} 187$ & 771 & $\begin{array}{l}6.02 \times 10^{\prime \prime} \\
{ }^{ \pm} 2.9 \times 10^{\prime \prime}\end{array}$ & 195 & $89 \pm 3.7$ \\
\hline 4-MeO-CB187 & 62.67 & $0.08 \pm 4.5 \times 10^{\mathrm{a}}$ & 23.5 & $90 \pm 2.6$ \\
\hline $4-\mathrm{OH}-\mathrm{CB} 187$ & 1.1 & $3.77 \pm 0.55$ & 11.1 & $91 \pm 2.7$ \\
\hline $\mathrm{T}_{4}$ & 10.31 & 1 & 27.5 & $91 \pm 3.7$ \\
\hline $\mathrm{CB} 187$ & 71.3 & $0.139 \pm 0.01$ & 36.04 & $76 \pm 5.8$ \\
\hline 4-MeO-CB187 & 941 & $0.010 \pm 1.35 \times 10^{\prime 3}$ & 432 & $86 \pm 2.6$ \\
\hline 4-OH-CB187 & 12.5 & $0.8 \pm 0.05$ & 10.8 & $90 \pm 1.8$ \\
\hline Human TTR & & & & \\
\hline $\mathrm{T}_{4}$ & 50.89 & 1 & 14.9 & $98 \pm 2.1$ \\
\hline $\mathrm{T}_{3}$ & 214 & $0.19 \pm 0.02$ & 60.1 & $77.3 \pm 3.7$ \\
\hline
\end{tabular}

Note: Results presented as the mean of individual measurements, and based on $n=6$ replicates (combined triplicates on two different days). The $\pm S D$ for relative potency and maximum \% competition is based on the standard deviation of the two values comprising the ratio. See Figure 6 for competitive binding curves.

${ }^{a} \mathrm{Ki}\left(\right.$ or $\left.I_{50}\right)=\mathrm{Kd}\left(1+\mathrm{T}_{0} / \mathrm{Kd}^{*}\right)$ (Cheng and Prusoff, 1973). See Materials and Methods section for further details.

${ }^{\mathrm{b}}$ Calculated as ratio of $I \mathrm{C}_{50}$ for a chemical $(\mathrm{Y} / \mathrm{X})=\mathrm{E}\left[\mathrm{Y}^{\mathrm{A}} 2\right] \mathrm{V}(1 / \mathrm{X})+\mathrm{V}(\mathrm{Y}) \mathrm{E}[M X]^{\mathrm{A} 2}$

${ }^{c}$ The $\mathrm{Kd}$ values (mean $\pm \mathrm{SD}$ ) were determined from the slope of the linear regression line of Scatchard plots

${ }^{d}$ Percentage of competition reached at highest tested concentration $\left(1 \times 10^{5} \mathrm{nM}\right)$. 
Table 2. Competitive binding parameters for gull transthyretin protein and T3 or $\mathrm{T} 4$ in the presence of model PBDE and structural analogue congener ligands.

\begin{tabular}{|l|l|l|l|l|}
\hline Compound & $\mathrm{KI}(\mathrm{nM})^{\mathrm{a}}$ & $\begin{array}{l}\text { Relative potency } \\
\mathbf{b}\end{array}$ & $\mathbf{K d}^{\mathrm{c}}$ & $\begin{array}{l}\text { Maximum \% } \\
\text { competition }\end{array}$ \\
\hline $\mathrm{T}_{3}$ & 4.48 & 1 & 13.1 & $87 \pm 4.3$ \\
\hline $\mathrm{BDE47}$ & 671 & $6.6914 .4 \mathrm{X} 10^{\prime \prime}$ & 201 & $88 \pm 3.8$ \\
\hline $6-\mathrm{OH}-\mathrm{BDE} 47$ & 78 & $0.07 \pm 3.91 \times 10^{\prime 3}$ & 7.1 & $91 \pm 2.7$ \\
\hline $4-\mathrm{OH}-\mathrm{BDE} 49$ & 57 & $0.81 \pm 0.013$ & 6.3 & $90 \pm 2.2$ \\
\hline 6-MeO-BDE47 & 233.7 & $0.01912 .3 \times 10-^{*}$ & 29.6 & $90 \pm 3.5$ \\
\hline $\mathrm{T}_{4}$ & 10.31 & 1 & 27.5 & $91 \pm 3.7$ \\
\hline $\mathrm{BDE47}$ & 89.1 & $0.13 \pm 0.02$ & 213 & $94 \pm 3.1$ \\
\hline 6-OH-BDE47 & 4.91 & $2.17 \pm 0.173$ & 14.9 & $96 \pm 2.6$ \\
\hline 4-OH-BDE49 & 4.68 & $2.20 \pm 0.161$ & 13.8 & $95 \pm 2.7$ \\
\hline 6-MeO-BDE47 & 54.32 & $0.189 \pm 0.032$ & 139.3 & $96 \pm 2.8$ \\
\hline
\end{tabular}

Note: Results presented as the mean of individual measurements, and based on $n=6$ replicates (combined triplicates on two different days). The $\pm S D$ for relative potency and maximum \% competition is based on the standard deviation of the two values comprising the ratio. See Figure 7 for competitive binding curves.

${ }^{a} \mathrm{Ki}\left(\right.$ or $\left.I_{50}\right)=K_{d}\left(1+T_{d} / K^{*}\right)$ (Cheng and Prusoff, 1973). See Materials and Methods section for further details.

"Calculated as ratio of $I C_{50}$ for a chemical $(Y / X)=E\left[Y^{A} 2\right] V(1 / X)+V(Y) E[1 / X]^{A} 2$

${ }^{\mathrm{c}}$ The $\mathrm{Kd}$ values (mean $\pm \mathrm{SD}$ ) were determined from the slope of the linear regression line of Scatchard plots

${ }^{d}$ Percentage of competition reached at highest tested concentration $\left(1 \times 10^{5} \mathrm{nM}\right)$. 


\subsubsection{Phylogenetic analysis and comparison to other vertebrates}

Herring gulls from Lake Ontario (Laurentian Great Lakes of North America) and glaucous gull from Bear Island, in the Norwegian Arctic are top avian predators in their respective aquatic ecosystems. Herring gulls in this study inhabits a freshwater system (Lake Ontario), and are distributed within a highly urbanized area such as the Greater Toronto Area, while the Bear Island glaucous gulls inhabit a marine system, and inhabit a more remote Arctic location where contaminant exposure is a manifestation of contaminant input through atmospheric transport and subsequently into the marine food web. The two gulls populations studied are exposed to different organohalogen profiles, and if they possess contrasting TTR protein structure (and consequently, ligand interactions); this factor may have a differential effect on the homeostasis of the circulating THs (McNabb 2003). In the present study, I compared the binding parameters of commercial human TTR and recombinant gullTTR. The recombinant gullTTR protein resembles the human TTR; however there is a truncation of approximately 26 amino acids in the N-terminal end of gull TTR. In addition, the recombinant TTR contains 6 histidine-tag residues. In the present attempt to further understand the similarities or differences of the present gullTTR with human TTR; one confounding factor to consider is that minor differences may have occurred in the post-translational modification of the recombinant gullTTR. 
This is the first report describing the TTR nucleic acid and amino acid sequences as well as the expression and purification of recombinant TTR from any gull species. Previously in birds, the synthesis, expression and secretion of TTR in the liver and choroid plexus has been demonstrated in chicken, quail and pigeon (Zanotti et al 2001). For this reason, it was presently decided to evaluate the expression of TTR mRNA in brain and liver of both gull species to identify possible differences or similarities. The TTR sequences in the liver and brain of both herring and glaucous gull were found to be identical, and thus it was possible to use one tissue source of TTR protein that was representative of Larus genus and for use in competitive binding assays. TTR is a major, circulating THbinding protein in birds, herbivorous marsupials and small eutherians (Richardson et al 1996). TTR is considered the only TH-binding protein that is synthesized in the cells of the blood-cerebro espinal fluid barrier, in addition to its synthesis in the liver (Schreiber and Richardson 1997). Comparison of the gull sequences with other vertebrate species showed the evolutionary conservation of TTR nucleotide and amino acid sequences (Figure 6 and 7). The deduced TTR amino acid sequences indicated that the protein is highly conserved among avian species. However, it was presently observed that the $\mathrm{N}$-terminal region of TTR was less homologous among species. This is not surprising since the noninvolvement of this region in and/or influencing $\mathrm{TH}$ binding was previously proposed by Chang and colleagues (1999). Overall, when grouped based on similarities in the alignment of genome sequences, the amino acids in the $\mathrm{N}$ terminal regions of the TTRs in marsupials, birds, reptiles, amphibians and fish, 
differ from that of the order insectivora (Schreiber and Richardson 1997). The basic structure of TTR (four identical subunits, central channel, $T_{4}$-binding sites in mammals) evolved while this protein was an extra-cellular brain protein, long before the initiation of its synthesis in the liver (Hamilton and Benson 2001). Although the TH binding region of TTR is highly conserved among vertebrate species including birds, other $\mathrm{TH}$ binding factors can affect the binding affinity among species and in different stages of development (Richardson et al 1994).

\subsubsection{Natural T3 and T4 ligand binding to gull rTTR versus human TTR}

The results obtained on this study showed that gullTTR is more effective at binding T3 relative to $T_{4}$, while for human TTR $T_{4}$ more effectively binds relative to $T_{3}$. This suggests that in gulls $T 3$ binding relative to that of $T_{4}$ would be less susceptible to competitive displacement by other endogenous or exogenous ligands present in the blood stream and targeting liver or brain. The thyroid gland synthesizes and releases into the circulation primarily $\mathrm{T}_{4}(95 \%, 5 \% \mathrm{~T} 3)$, which is the less active precursor that is subsequently deiodinated to T3 at the target tissues. Besides the differences among avian and mammalian TTR binding $T_{3}$ and $\mathrm{T}_{4}$, in mammals about $12 \%$ of total $\mathrm{TH}$ transport protein is synthesized by the choroid plexus, where about $50 \%$ of the protein secreted is TTR (Schreiber and Richardson 1997). The present results suggest that since much more $\mathrm{T}_{4}$ (relative to T3) is associated with circulating TTR, in the gulls relative to humans exogenous ligand competition on circulating levels of $\mathrm{T}_{4}$ may present disrupting affinity. The relative $\mathrm{T} 3 / \mathrm{T}_{4}$ binding affinity for human and gull TTR may be 
partially explained from an evolutionary perspective, where different taxon levels have differing specificity with respect to transport proteins and the hormones transported.

For the present gull TTR, where T3 is more effectively bound than $T_{4}$, there is a consistency with other reports in the literature, where it has been reported that chicken TTR has about twice the affinity for $T_{3}$ relative to T4 (Schreiber 2002). TTR in birds, reptiles, amphibians, and teleost fish have generally been found to preferentially bind $T_{3}$ over $T_{4}$ (Kawakami et al 2006). The preference of avian TTR for $T_{3}$ relative to T4 could be related to the $\mathrm{N}$-terminus of the TTR subunits that are more than merely changes in the primary structure, but are manifested in the relative affinity of the TTR homotetramer for T4 and T3. Prapunpoj et al (2006) recently demonstrated in a reptile model the causal relationship between the $\mathrm{N}$ terminal region of the TTR subunits and the affinity of the homotetramer for THs. They showed that removing the N-terminus of the Crocodylus porosus TTR subunit or replacing it with the $\mathrm{N}$-terminus of the human subunit resulted in a homotetramer with increased affinity for T4. The present human TTR binding results are also consistent with that for humans, where mammalian TTR preferentially binds $\mathrm{T} 4$ relative to $T_{3}$. In addition, in humans, TTR has higher affinity for THs than albumin, and TBG has higher affinity for THs than TTR. Schreiber and Richardson (1997) suggested that the onset of hepatic TTR synthesis correlated with the development of homeothermy and the increase in lipid volume to body mass ratio. 
3.3.5 Competitive gull rTTR binding of $T_{3}$ and $T 4$ with exogenous contaminant ligands

PBDEs are used as a flame retardant. Like other brominated flame retardants, PBDEs have been used in a wide array of products, including building materials, electronics, furnishings, motor vehicles, plastics, polyurethane foams, and textiles. They are produced as commercial mixtures, and congeners such as BDE-47 are persistent and bioaccumulative in wildlife such as Great Lakes herring gulls and Svalbard glaucous gulls and/or their eggs (Gauthier et al 2008). Several $\mathrm{OH}-\mathrm{PCB}$ and $\mathrm{OH}-\mathrm{PBDE}$ congeners, and to a much lesser extent methoxylated (MeO)-PBDEs, were recently quantified in glaucous gull adult plasma from the Norwegian Arctic (Verreault et al 2005a; 2005b), where 6-OHBDE47, 4'-OH-BDE49, 3,-MeO-BDE47, 4'-MeO-BDE49, and most important among the $\mathrm{OH}-\mathrm{PCBs}, 4-\mathrm{OH}-\mathrm{CB} 187$ were dominant. The persistence of $\mathrm{OH}-\mathrm{PCB}$ and OH-PBDE congeners in the blood of birds and other wildlife has been postulated as being via competitive binding to $\mathrm{TH}$ transport proteins and specifically TTR.

Better understanding of OH-PCB and OH-PBDE binding with TTR (and other TH transport proteins) is important with respect to effects on the thyroid system and target organs, e.g., in the brain because the binding of $\mathrm{OH}-\mathrm{PCBs}$ and $\mathrm{OH}-\mathrm{PBDEs}$ to TTR may be an avenue for these chemicals to reach TH receptors. OH-PCB congeners (e.g., 4-OH-CB106) have been shown to bind to the human thyroid 
hormone receptor (TR) (You et al 2006). Kimura-Kuroda et al (2005) reported that 4'-OH-CB106 and 4'-OH-CB159 significantly inhibited $\mathrm{T}_{3}$-dependent extension of Purkinje cell dendrites extracted from mouse cerebellum in vitro.

In the present study, the gull rTTR binding affinity or potency was exceptionally low for $\mathrm{BDE}-47$ relative to $\mathrm{T} 4$ or $\mathrm{T}_{3}$ and as compared to the MeO-BDE and especially the OH-BDE ligands. This is consistent with a previous study on the PBDE competitive binding with T4 and human TTR, where no substantial TTR binding was observed for 17 PBDE congeners, including BDE-47, at maximum concentrations of $0.25 \mathrm{uM}$ (Meerts et al 2001). Morgado et al (2007) also reported a lack of competitive PBDE congener binding with sea bream TTR but even at higher concentrations. The present results are also consistent were the results reported by Hamers et al (2006) who screened a test set of 27 individual BFRs, including 19 PBDE congeners and 6-OH-BDE47, for their relative potency to compete with T4 for binding in vitro with human TTR. With T4 and human TTR, Meerts et al (2001) reported high human TTR binding competitive with T4 for 6$\mathrm{OH}-\mathrm{BDE} 47$, but was of lesser potency than for other brominated phenolic substances and used as flame retardants such as tetrabromobisphenyl A (TBBPA) and 2,4,6-tribromophenol (2,4,6-TBP). The TTR-binding potencies of TBBPA and 2,4,6-TBP exceeded that of the native prohormone T4. For both $\mathrm{OH}$ PBDEs and OH-PCBs, it has been proposed that for optimal human TTR competitive binding (with T4), hydroxylation should exist at a para position (relative to the aromatic ring linkage), and that there be at least one, but 
preferably two, halogen substituents on carbons adjacent to the $\mathrm{OH}$-group (Lans et al 1993; Harriers et al 2006; Morgado et al 2007). TTR is a homotetramer consisting of a dimer of dimers. The binding channel for $\mathrm{TH}$ is at the interaction site between the two dimers. In this study it is also possible that the high differences found in the $K_{d}$ and $K j$ values comparing gull TTR with human TTR binding could be attribute to the fact that I studied the interaction between THs and organohalogen compounds with the dimer form.

The present results demonstrate profound differences in the binding affinity of $T_{4}$ and $T_{3}$ and several environmentally relevant PCB, PBDE, OH-PCB, OH-PBDE, and MeO-PCBs and MeO-PBDEs for both human and/or gull TTR. Regardless, the $\mathrm{OH}$-containing forms of PCBs and PBDEs are strong binding competitors for gull TTR. Depending on the circulatory quantities of OH-PCBs and OH-PBDEs circulating on plasma, it is possible an influence and/or change on the circulating THs, both levels and relative proportions of T3 and T4. Such TTR interactions could affect the circulatory $\mathrm{TH}$ homeostasis, and perhaps the $\mathrm{TH}$-dependent function and health of exposed birds. OH-PCB binding affinity to TTR in mammals has been linked to alterations of $\mathrm{TH}$ and vitamin $\mathrm{A}$ levels in $\mathrm{OH}-\mathrm{PCB}$ exposed laboratory rats (Schuur et al 1998). Thyroidogenic contaminants such as PCBs, PBDEs, OH-PCBs and OH-PBDEs that can displace $\mathrm{T}_{4}$ from TTR, would subsequently release free $\mathrm{T} 4$, which may enhance $\mathrm{T} 4$ metabolism and excretion (Brouwer et al 1998). A sufficiently increased excretion of T4 could result in a decrease in circulating T4, leading to potential hypothyroidism. 
To my knowledge, there are no reports on circulating OH-PCB, OH-PBDE, PBDE or possibly MeO-PBDEs in herring gulls from the Laurentian Great Lakes. Recently it was reported that the mean concentrations of 6-OH-BDE47 and 4'$\mathrm{OH}-\mathrm{BDE} 49$ in the plasma of male and female glaucous gulls from the Norwegian Arctic was up to $0.32 \mathrm{ng} / \mathrm{g}$ (wet weight) (Verreault et al 2005b), which is -0.0006 $\mathrm{nM}$. The competitive potency $\left(\mathrm{IC}_{5} \mathrm{O}\right)$ was $-10 \mathrm{nM}$ for both $\mathrm{OH}-\mathrm{PBDE}$ congeners with $T_{3}$ and $T_{4}$ on gullTTR, and therefore in free-ranging Svalbard gulls $\mathrm{OH}$ PBDEs are not likely to substantially affect circulating $T_{3}$ or $T_{4}$ levels.

In contrast to $\mathrm{OH}-\mathrm{PBDEs}$, the mean concentrations of $4-\mathrm{OH}-\mathrm{CB} 187$ in the plasma of male and female glaucous gulls from the Norwegian Arctic was up to $17.5 \mathrm{ng} / \mathrm{g}$ (wet weight) (Verreault et al., 2005a), which is $-0.04 \mathrm{nM}$. The competitive potency (IC50) was 5 to $10 \mathrm{nM}$ for 4-OH-CB187 with T3 and T4 on gullTTR, and thus 4-OH-CB187 levels in free-ranging Svalbard gulls may be high enough to effect circulating T3 or T4 levels. It is highly probable that the patterns and levels of exposure to these $\mathrm{OH}$-containing contaminants differ in Great Lakes herring gull blood, and thus the potential effects on circulating T3 and T4 with respect to TTR interaction. 


\subsubsection{Conclusions}

The present gullTTR molecular characterization and competitive binding studies clearly showed that human TTR cannot be used as a surrogate to assess the effects on circulating THs in birds (or at least gull species). The present results also demonstrate that there are potential physiological consequences of the competitive binding of $\mathrm{OH}$-containing organohalogens to gull TTR. In birds and other wildlife, displacement of T4 from TTR would provide more $T_{4}$ to target tissues and would increase the amount of substrate for deiodinase enzymes, including the 5 ' deiodinases $\mathrm{DI}$ and $\mathrm{DM}$, which can convert T4 to its active form T3 (Verhoelst et al., 2005). Like other bird species, gulls not only have TTR but also ALB, which also bind and are involved in the transport of THs. However, in the context of overall TH binding in birds, TTR may be of lesser importance. For example, in birds the proportion of circulating TH-binding transport proteins is low for TTR. McNabb et al $(1984,2003)$ reported that in chicken the circulating T4 is bound $75 \%$ to ALB, $17 \%$ to TTR and $7.5 \%$ to a a-globulin.

Ligand binding parameter assessments for TH transport protein in gull species, and in wildlife in general, are necessary to more fully understand the potential effects in reproductive, nutritional, physiological and environmental (e.g., temperature) factors that can influence circulating T4 and T3 and subsequently on TH-depending processes. 


\subsection{References}

Bradford, M. (1976). A rapid and sensitive method for the quantitation of microgram quantities of protein utilizing the principle of protein-dye binding. Anal. Biochem. 72, 248-254.

Brouwer, A., Morse, D.C., Lans, M.C., Schuur, A.G., Murk, A.J., Klasson-Wehler, E., Bergman, A., and Visser, T.J. (1998). Interactions of persistent environmental organohalogens with the thyroid hormone system: Mechanisms and possible consequences for animal and human health. Toxicol. Ind. Health 14, 59-84.

Chang, L, Munro, S.L.A., Richardson, S.J., and Schreiber, G. (1999). Evolution of thyroid hormone binding by transthyretins in birds and mammals. Eur. J. Biochem. 259, 534-542.

Cheng, Y., and Prusoff, W.H. (1973). Relationship between inhibition constant $(\mathrm{Kj})$ and concentration of inhibitor which causes 50 per cent inhibition $\left(\mathrm{I}_{50}\right)$ of an enzymatic-reaction. Biochem. Pharmacol. 22, 3099-3108.

Costa, L.G., and Giordano, G. (2007). Developmental neurotoxicity of polybrominated diphenyl ether (PBDE) flame retardants. Neurotoxicol. 28, 10471067.

Decuypere, E., Van-As, P., Van der Geyten, S., and Darras, V.M. (2005). Thyroid hormone availability and activity in avian species: A review. Dom. Animal Endocrinol. 29(1), 63-77.

Dickson, P.W., Aldred, A.R., Menting, J.G.T., Marley, P.D., Sawyer, W.H., and Schreiber, G. (1987). Thyroxine transport in choroid plexus. J. Biol. Chem. 262, 13907-13915.

Ekins, R. (1990). Measurement of free hormones in blood. Endocr. Rev. 11,546.

Galtier, N., Gouy, M., and Gautier, C. (1996). SEAVIEW and PHYLO_WIN: Two graphic tools for sequence alignment and molecular phylogeny. Comput. Appl. Biosci. 12, 543-548.

Gauthier, L.T., Hebert, C.E., Weseloh, D.V.C., and Letcher, R.J. (2008). Dramatic changes in the temporal trends of polybrominated diphenyl ethers (PBDEs) in herring gull eggs from the Laurentian Great Lakes: 1982-2006. Environ. Sci. Technol. 42(5), 1524-30.

Hakk, H., and Letcher, R.J. (2003). Metabolism in the toxicokinetics and fate of brominated flame-retardants - a review. Environ. Intemat. 29, 801-828. 
Harriers, T., Kamstra, H.J., Sonneveld, E., Murk, A.J., Kester, M.H.A., Andersson, P.A., Legler, J., and Brouwer, A. (2006). In vitro profiling of the endocrine-disrupting potency of brominated flame retardants. Toxicol. Sci. 92(1), 157-173.

Hamilton, J. A., and Benson, M. D. (2001). Transthyretin: A review from a structural perspective. Cell Mol. Life Sci. 58, 1491-1521.

Ishihara, A., Nishiyama, N., Sugiyama, S., and Yamauchi, K. (2003a). The effect of endocrine disrupting chemicals on thyroid hormone binding to Japanese quail transthyretin and thyroid hormone receptor. Gen. Comp. Endocrinol. 134, 36-43

Ishihara, A., Sawatsubashi, S., and Yamauchi, K. (2003b). Endocrine disrupting chemicals: Interference of thyroid hormone binding to transthyretins and to thyroid hormone receptors, Mol. Cell. Endocrinol. 199, 105-117.

Kawakami, Y., Shin, D.W., Kitano, T., Adachi, S., Yamauchi, K. and Ohta, H. (2006). Transactivation activity of thyroid hormone receptors in fish (Conger myriaster) in response to thyroid hormones. Comp. Biochem. Physiol. - Part B 144(4), 503-509.

Kimura-Kuroda, J., Nagata, I., and Kuroda, Y. (2005). Hydroxylated metabolites of polychlorinated biphenyls inhibit thyroid-hormone-dependent extension of cerebellar Purkinje cell dendrites. Brain Res. 154, 259-263.

Ktihn, E.R., and Nouwen, E.J. (1978), Serum levels of triiodothyronine and thyroxine in the domestic fowl following mild cold exposure and injection of synthetic thyrotropin-releasing hormone. Gen. Comp. Endocrinol. 34, 336-342.

Lans, M.C., Klasson-Wehler, E., Willemsen, M., Meussen, E., Safe, S., and Brouwer, A. (1993). Structure- dependent, competitive interaction of hydroxypolychlorobiphenyls, -dibenzo-p-dioxins and dibenzofurans with human transthyretin. Chem.-Biol. Interact. 88, 7-21.

Malmvarn, A., Marsh, G., Kautsky, L, Athanasiadou, M., Bergman, A., and Asplund, L. (2005). Hydroxylated and methoxylated brominated diphenyl ethers in the red algae Ceramium

tenuicome and blue mussels from the Baltic Sea. Environ. Sci. Technol. 39, 2990-2997.

McKinney, M.A., Cesh, L, Elliott, J.E., Williams, T.D., Garcelon, D.K., and Letcher R.J. (2006). Brominated flame retardants and halogenated phenolic compounds in North American west coast bald eaglet (Haliaeetus leucocephalus) plasma. Environ. Sci. Technol. 40, 6275-6281. 
McKinnon, B., Huika, L., Kerry, R., Robin, M. (2005). Synthesis of thyroid hormone binding proteins transthyretin and albumin by human trophoblast. J. Clin. Endocrinol. Metab. 90(12), 6714-6720.

McNabb, F.M.A., Stanton, F.W., and Dicken, S.G. (1984). Post-hatching thyroid development and body growth in precocial vs. altricial birds, Comp. Biochem. Physiol .-Part A 78, 629-635.

McNabb, F.M.A., and Fox, G.A. (2003). Avian thyroid development in chemically contaminated environments: is there evidence of alterations in thyroid function and development? Evol. Develop. 5, 76-84.

Meerts, I.A.T.M., van Zanden, J.J., Luijks, E.A.C., van Leeuwen-Bol, I., Marsh, G., Jakobsson, E., Bergman, A., and Brouwer, A. (2000). Potent competitive interactions of some brominated flame retardants and related compounds with human transthyretin in vitro. Toxicol. Sci. 56, 95-104.

Meerts, I.A.T.M., Letcher, R.J., Hoving, S., Marsh, G., Bergman, A., Lemmen, J.G., van der Burg, B., and Brouwer, A. (2001). In vitro estrogenicity of polybrominated diphenyl ethers, hydroxylated PBDEs, and polybrominated Bisphenol A compounds. Environ. Health Perspect. 109(4), 399-407.

Mineau, P., Fox, G.A., Norstrom, R.J., Weseloh, D.V., Hallett, D.J., and Ellenton, J.A. (1984). Using the herring gull to monitor levels and effects of organochlorine contamination in the Canadian Great Lakes. In Toxic Contaminants in the Great Lakes (J.O. Nriagu and M.S. Simmons, Eds.), pp. 425-452. John Wiley \& Sons, New York.

Morgado, I., Hamers, T., Van der Ven, L., and Power, D.M. (2007). Disruption of thyroid hormone binding to sea bream recombinant transthyretin by ioxinyl and polybrominated diphenyl ethers. Chemosphere 69(1), 155-163

Power, D.M., Elias, N.P., Richardson, S.J., Mendes, J., Soares, CM., and Santos, C.R.A. (2002). Evolution of the thyroid hormone-binding protein, transthyretin. Gen. Comp. Endocrinol. 119(3), 241-255.

Prapunpoj, P., Richardson, S.J., Fumagalli, L., and Schreiber, G. (2000). The evolution of the thyroid hormone distributor protein transthyretin in the order insectivora, class mammalia. Mol. Biol. Evol. 17(8), 1199-1209.

Prapunpoj, P., Richardson, S.J., and Schreiber, G. (2002). Crocodile transthyretin: Structure, function, and evolution. Am. J. Physiol. Regul. Integr. Comp. Physiol. 283, R885-R896. 
Prapunpoj, P., Leelawatwatana, L, Schreiber, G., and Richardson, S.J. (2006). Change in structure of the $\mathrm{N}$-terminal region of transthyretin produces change in affinity of transthyretin to T4 and T3. FEBS J. 273(17), 4013-4023.

Purkey, H.E., Palaninathan, S.K., Kent, K.C., Smith, C, Safe, S.H., Sacchettini, J.C., and Kelly, J.W. (2004). Hydroxylated polychlorinated biphenyls selectively bind transthyretin in blood and inhibit amyloidogenesis: rationalizing rodent PCB toxicity. Chem. Biol. 11, 1719-28.

Richardson, S.J., Bradley, A.J., Duan, W., Wettenhall, R.E.H., Harms, P.J., Babon, J.J., Southwell, B.R., Nicol, S., Donnellan, S.C., and Schreiber, G. (1994). Evolution of marsupial and other vertebrate thyroxine-binding plasma proteins. Am. J. Physiol. 266, R1359-R1370.

Richardson, S.J.R., Whettenhall, E.H., and Schreiber, G. (1996). Evolution of transthyretin gene expression in the liver of Didelphis virginiana and other American marsupials. Endocrinol. 137, 3507-3512.

Saitou, N., and Nei, M. (1987). The neighbor-joining method: A new method for reconstructing phylogenetic trees. Mol. Biol. Evol. 4, 406-425.

Schreiber, G., and Richardson, S.J. (1997). The evolution of gene expression, structure and function of transthyretin, Comp. Biochem. Physiol. - Part B 116, 137-160.

Schreiber, G. (2002). Beyond carrier proteins. The evolutionary and integrative roles of transthyretin in thyroid hormone homeostasis. J. Endocrinol. 175, 61-73.

Schuler, G., D., Altschul, S. F., and Lipman, D. J. (1991). A workbench for multiple alignment construction and analysis. Proteins: Structure, Function, and Genetics 9, 180-190.

Schuur A.G., Legger, F.F., van Meeteren, M.E., Moonen, M.J.H., van LeeuwenBol, I., Bergman, A., Visser, T.J., and Brouwer, A. (1998). In vitro inhibition of thyroid hormone sulfation by hydroxylated metabolites of halogenated aromatic hydrocarbons. Chem. Res. Toxicol. 11, 1075-1081.

Silva, J.E. (1995). Thyroid hormone control of thermogenesis and energy

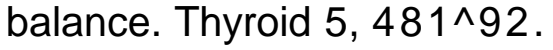

Ulrich, R.G. (2003). The toxicogenomics of nuclear receptor agonists. Cur. Opin. Chem. Biol. 7(4), 505-510.

Verhoelst, C.H.J., Van der Geyten, S., Roelens, S.A., and Darras, V.M. (2005). Regulation of thyroid hormone availability by iodothyronine deiodinases at the blood-brain barrier in birds, Ann. NY Acad. Sci. 1040, 501-503. 
Verreault, J., Skaare, J.-U., Jenssen, B.M., and Gabrielsen, G.W. (2004). Effects of organochlorine contaminants on thyroid hormone levels in Arctic breeding glaucous gulls, Larus hyperboreus. Environ. Health Perspect. 112, 532-53.

Verreault, J., Letcher, R.J., Muir, D.C.G., Chu, S.G., Gebbink, W.A., and Gabrielsen, G.W. (2005a). New organochlorine contaminants and metabolites in plasma and eggs of glaucous gulls (Larus hyperboreus) from the Norwegian Arctic. Environ. Toxicol. Chem. 24, 2486-2499.

Verreault, J., Gabrielsen, G.W., Chu, S.G., Muir, D.C.G., Andersen, M., Hamaed, A., and Letcher, R.J. (2005b). Flame retardants and methoxylated and hydroxylated polybrominated diphenyl ethers in two Norwegian Arctic top predators: Glaucous gulls and polar bears. Environ. Sci. Technol. 39, 6021-6028.

Yamauchi, K., Takeuchi, H., Overall, M., Dziadek, M., Munro, S.L.A., and Schreiber, G. (1998). Structural characteristics of bullfrog (Rana catesbeiana) transthyretin and its cDNA - comparison of its pattern of expression during metamorphosis with that of lipocalin. Eur. J. Biochem. 256, 287-296.

Yamauchi, K., Nakajima, J., Hayashi, H., Hara, A., and Yamauchi, K. (1999). Purification and characterization of thyroid-hormone-binding protein from masu salmon serum: a homolog of higher-vertebrate transthyretin. Eur. J. Biochem. 265, 944-949.

You, S.H., Gauger, K.J., Bansal, R., and Zoeller, R.T. (2006). 4-Hydroxy-PCB106 acts as a direct thyroid hormone receptor agonist in rat GH3 cells. Mol. Cell. Endocrinol. 257-258, 26-34.

Zanotti, G., Calderone, V., Beda, M., Malpeli, G., Folli, C, and Berni, R. (2001). Structure of chicken plasma retinol-binding protein. Biochim. Biophys. Acta Prot. Struct. Mol. Enzymol. 1550(1), 64-69.

Zoeller, R.T., Dowling, A.L.S., Herzig, C.T.A., lannacone, E.A., Gauger, K.J., and Bansal, R. (2002). Thyroid hormone, brain development, and the environment. Environ. Health Perspect. 110, 355-361. 


\section{CHAPTER FOUR ${ }^{2}$}

\section{Recombinant albumin transport protein from gull species (Larus argentatus and hyperboreus) and human: Chlorinated and brominated contaminant binding and thyroid hormones.}

\subsection{Abstract}

Glaucous gulls from Norway and herring gulls from Great Lakes of North America are differentially exposed to chlorinated and brominated contaminants that can perturb thyroid hormone-dependent processes. Environmentally relevant concentrations of selected polychlorinated biphenyl (PCB) and polybrominated diphenyl ether (PBDE) flame retardant congeners and their hydroxylated $(\mathrm{OH})$ and methoxylated $(\mathrm{MeO})$ analogues were comparatively examined with respect to competitive binding with thyroxine $\left(\mathrm{T}_{4}\right)$ and 3,5,3'-triiodothyronine (T3) thyroid hormones (THs) on recombinant human and gull albumin and transthyretin transport proteins. I isolated, cloned, sequenced, purified and expressed the complementary DNA (cDNA) of albumin from liver of herring and glaucous gull. Concentration-dependent, competitive binding curves were generated for $T_{4}$ and T3 binding alone and for selected substrates using gull and human recombinant

${ }^{2}$ This chapter is based on an accepted paper in a peer-reviewed journal. "Ucan-Marin F, Arukwe A, Mortensen A, Gabrielsen GW, Letcher RJ, 2009. Recombinant albumin transport protein from gull species (Larus argentatus and hyperboreus) and human: Chlorinated and brominated contaminant binding and thyroid hormones. Environ. Sci. Technol. Article ASAP Publication Date (Web): December 3, 2009). 
albumin (recALB). Albumin amino acid sequences were identical for both gull species, and in phylogenetic comparisons, was $\sim 70 \%$ similar to human sequence. Human recALB had high preference for $T_{4}$ relative to $T_{3}$ whereas it was reversed for gull recALB. Binding assays with recALB and recTTR gull proteins showed that relative to 2,2',4,4'-tetrabromoDE (BDE47) and 2,2',3,4',5,5',6-heptaCB (CB187) and the MeO-substituted (4-MeO-CB187 and 6MeO-BDE47) analogues, 4-OH-CB187, 6-OH-BDE47 and 4'-OH-BDE49 had greater affinity than $\mathrm{T} 3$ or $\mathrm{T}_{4}$. These results indicate that xenobiotic ligand binding to human albumin or TTR cannot be used as a surrogate for gull binding interactions. The combination of TH-like brominated diphenyl ether backbone (relative to the chlorinated biphenyl backbone), and the presence of $\mathrm{OH}$-group produced a more effective competitive ligand on human and gull recALB and recTTR relative to both $T_{3}$ and $T_{4}$. This suggests the possibility that $\mathrm{OH}$ substituted organohalogen contaminants may be an exposure concern to the thyroid system in free-ranging gulls as well as for humans. 


\subsection{Introduction}

Disruption of the endocrine system by xenobiotic compounds continues to be reported in humans and wildlife. More specifically, growing evidence is being reported on the (potential) effects and impacts of organohalogen exposure on the thyroid system of vertebrates (Miller et al 2009; Tan and Zoeller 2007). Thyroid hormones (THs) are crucial for many biological processes and thyroid disruption can compromise normal development and physiology of exposed humans and biota (Boas et al 2006; Chan and Kilby 2000). THs include I-thyroxine ( $\left.T_{4}\right)$ and its biologically active metabolite, 3',5,3-triidothyronine $\left(T_{3}\right)$. THs perform important roles via multiple pathways and molecular signaling in vertebrates including birds, e.g., development and differentiation of several tissues, energy balance and metabolism, and modulation of cellular metabolic rate (Bernal et al 2003; Miller et al 2009).

The thyroid gland produces and releases T4 in response to the thyroidstimulating hormone (TSH) released by the pituitary. Once T4 enters the blood stream, it is bound to TH-binding proteins (THBPs) and distributed to the target tissues. T4 is specifically transported through the cell membrane into intracellular compartments in different tissues and deiodinated to T3 (Friesema et al 2005). In vertebrates, THBPs include transthyretin (TTR), thyroxine-binding globulin (TBG) and albumin (Morgado et al 2007). Albumin is one THBP that is relatively non- 
selective for hormones and found at high concentrations in the blood of all vertebrates including birds (Baker 2002). Albumin is the major circulating THBP in birds, herbivorous marsupials and small eutherians (Richardson et al 1994, 1996).

Thyroid system disrupting chemicals, e.g., those structurally and chemically resembling $\mathrm{T}_{4}$ and $\mathrm{T} 3$, may target multiple $\mathrm{TH}$ control pathways in a chemicaldependent manner. Thyroid disruption may be via a variety of mechanisms depending on the different levels that a chemical interferes with the hypothalamic-pituitary-thyroid axis (Boas et al 2006). The mechanism of interference can include $\mathrm{TH}$ production and metabolism (e.g., TH degradation and interconversion), thyroid receptor (TR) binding and interaction with THBPs (Miller al 2009; Ulrich 2003). A major concern is that TH-dependent processes such as TH transport are susceptible to chemical stress and can be disrupted by thyroidogenic, xenobiotic compounds accumulated in humans and wildlife (Ishihara et al 2003; Letcher et al 2009; Miller et al 2009).

Polychlorinated biphenyl (PCB) and polybrominated diphenyl ether (PBDE) flame retardant congeners are environmentally relevant organohalogen contaminants (OHCs), and as well as some of their hydroxylated $(\mathrm{OH})$ analogues they have been reported to have effects on TH-dependent processes, including TTR-TH binding in in vitro and in vivo studies with non-avian species (Hakk and Letcher 2003; Legler and Brouwer 2003; Letcher et al 2000; Meerts et al 2000; 2001). 
Ishihara et al (2003) examined the effects of industrial, medical and agricultural chemicals on ${ }^{125} \mathrm{I}-\mathrm{T} 3$ binding to TTRs and TH receptors in chicken and bullfrog. I recently reported on contaminant competitive binding with THs and gull TTR protein (Ucan-Marin et al 2009). However, to my knowledge, there are no reports on competitive binding interactions between halogenated organic contaminant and THs on albumin for any vertebrate species including birds.

The presence of OH-PCBs in avian plasma and other wildlife it is likely due to oxidative cytochrome P450 (CYP)-mediated PCB biotransformation (Letcher et al 2000; Park et al 2009). The metabolism of PCBs and particularly PBDE flame retardants are not well understood (Hakk and Letcher 2003). However, Stapleton et al (2009) recently reported on BDE-99 metabolism to OH-PBDEs in vitro in human hepatocytes. Nevertheless, OH-PCBs and OH-PBDEs have been reported in diverse tissues (mainly in blood) of wildlife species, including a few gull (Land) species. Several OH-PCB and OH-PBDE congeners, and to a much lesser extent methoxylated (MeO)-PBDEs, has been quantified in the plasma of adult Arctic seabirds from the Norwegian Arctic (Letcher et al 2009; Verreault et al 2005a, 2005b).

In the present study, liver tissues of two gull species and populations, $L$. hyperboreous from Arctic Svalbard and L. argentatus from the Laurentian Great Lakes of North America, were used to isolate, clone and sequence albumin cDNA, with a subsequent expression and purification of recALB protein. Given 
the known environmental relevance of certain PCB, PBDE, OH-PCB and $\mathrm{OH}$ PBDE congeners in e.g. glaucous gulls, and the strong competitive binding interaction with THs for gull recTTR (Ucan-Marin et al 2009), I investigated the competitive binding (with $T_{3}$ or $T_{4}$ ) with the isolated gull recALB, and compared to commercially available human recALB, and relative to human and gull recTTR.

\subsection{Results and Discussion}

\subsubsection{Cloning and characterization of gull albumin}

As I reported previously, cDNA sequences of herring and glaucous gull TTR from both liver and brain were identical (Ucan-Marin et al 2009). Thus, I isolated gull albumin cDNA from the liver and from the same herring and glaucous gulls. Albumin was sequenced in both directions and observed to have identical nucleotide sequences between the species analyzed. Translation of nucleotide sequence showed 490 amino acid residues (Figure 12) with a putative molecular weight of 55.3 kiloDalton $(\mathrm{kDa})$ and theoretical isoelectric point (pi) of 6.34 . The sequence of the present gull albumin was compared with albumin sequences from other species, i.e. chicken, humans, rat, gecko, frog, salmon (Figure 13). The phylogenetic tree indicates that gull albumin shares more homology with mammalian (-70\%) than amphibian and fish albumin. 

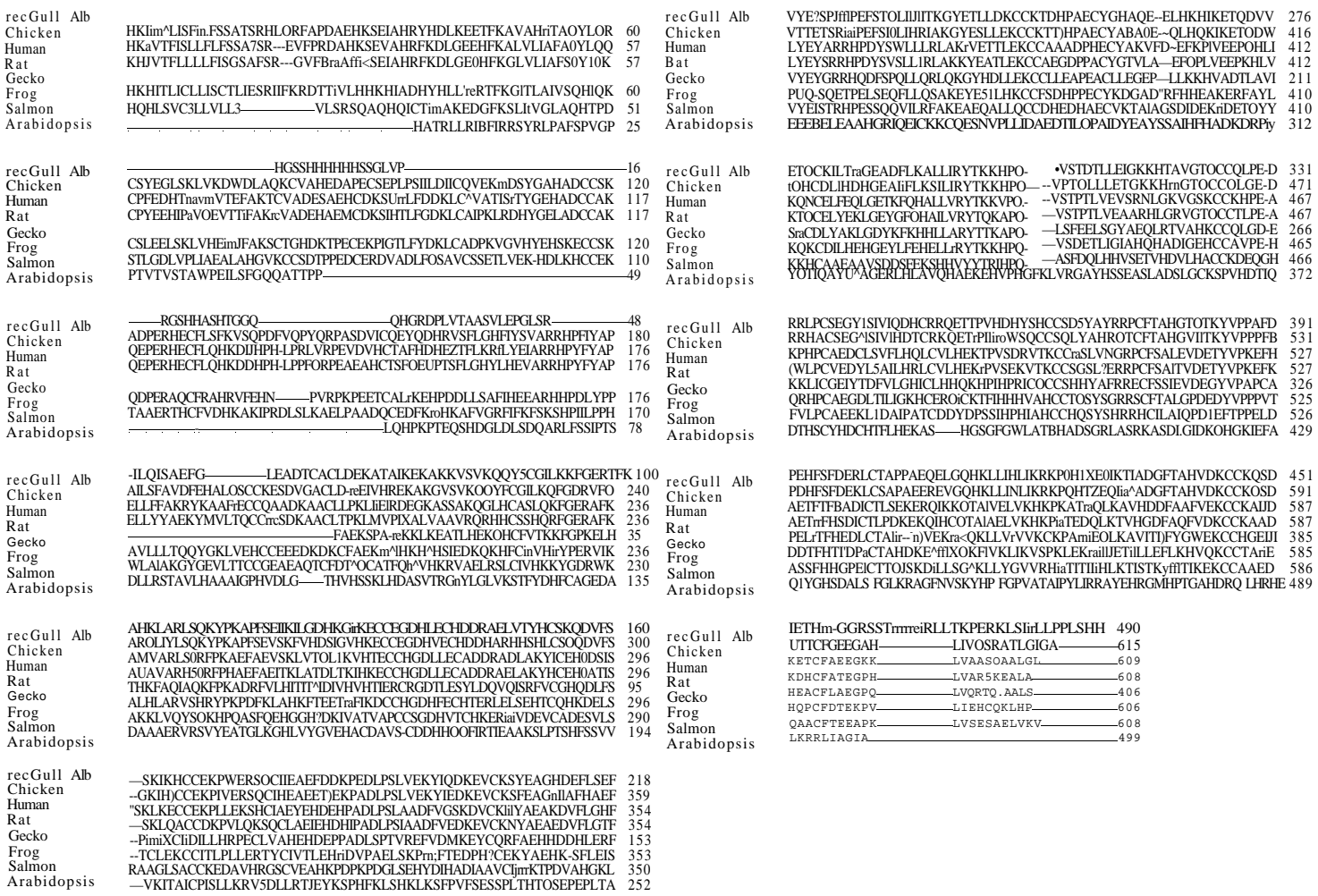

ASSFHHGPEICTTOJSKDiLLSG^KLLYGVVRHiaTTTIIHLLKTISTKYffITIKEKCCAAED 586
QIYGHSDALS FGLKRAGFNVSKYHP FGPVATAIPYLIRRAYEHRGMHPTAHDRQ LHRHE 489

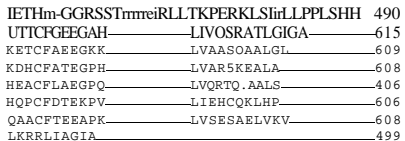

Figure 12. Multiple alignments of recombinant gull albumin sequence with serum albumin sequences from chicken, gecko, rat, human, frog and salmon was generated using MACAW. GenBank accession numbers are: Larus sp. (temp access \# Icl|50720), Gallus gallus (NP_990592), Hoplodactylus maculatus (AF375972), Homo sapiens (AAX63425), Rattus norvegicus (NP599153), Xenopus laevis (NP001081244) and Salmo salar (P21848). 
Human

Rat

Frog

Gecko

Figure 13. Phylogenetic analysis of the amino acid sequences of albumin of vertebrate species. The amino acid sequences of albumin were aligned using ClustalW analysis, and Bootstrap values based on 100 samplings. The osmotic stress-induced proline dehydrogenase sequence of Arabidopsis thaliana (accession no. AAB40615) was used as outgroup. The other protein accession numbers used; Larus sp. (temp access \# Icl|50720), Gallus gallus (NP_990592), Hoplodactylus maculatus (AF375972), Homo sapiens (AAX63425), Rattus norvegicus (NP599153), Xenopus laevis (NP001081244) and Salmo salar (P21848). 


\subsubsection{Substrate competitive binding with thyroid hormones}

To establish a standard competitive binding curve, in the absence of binding competitors human recALB was observed to have a greater binding affinity for T4 than for $T_{3}$, whereas for gull recALB $T_{3}$ was much greater than T4 (Figure 14). As summarized in Tables 3 and 4, for gull recALB the $K \backslash$ was lower for T3 (1.12) relative to T4 (5.11), and the $K \backslash$ for gull recTTR was also lower for $\mathrm{T}_{3}$ (5.99) relative to $T_{4}$ (15.74) and thus greater binding affinity of $T_{3}$ to both recALB and recTTR. In contrast, the reverse was found for human recTTR and recALB. That is, the $K$, for human recTTR was higher for $\mathrm{T}_{3}$ (207.67) relative to $\mathrm{T}_{4}$ (56.88), and similarly for human recALB the $K \backslash$ was higher for $T_{3}$ (23.88) relative to $T_{4}$ (7.91), and thus greater binding affinity of $T_{4}$ to both recALB and recTTR.

Competitive $T_{3}$ and $T_{4}$ binding assays in presence of selected exogenous contaminant substrates were performed with purified human and gull recALB (Figures 15 and 16). CB187 and 4-MeO-CB187 had lower affinity than 4-OHCB187 (Figure 15), and 4-OH-CB187 was the most potent as a competitive substrate for the displacement either $\mathrm{T}_{3}$ or $\mathrm{T}_{4}$ (Table 3). However, one exception was that for $\mathrm{T}_{3}$ with gull recTTR, 4-MeO-CB187 had a higher binding affinity than CB187, whereas the reverse was true for competition with $T_{4}$. The gull recALB affinity of the selected brominated compounds (Table 4) shows that BDE47 and 6-MeO-BDE47 had a lower binding affinity for both $\mathrm{T}_{3}$ and $\mathrm{T}_{4}$ relative to $4{ }^{\prime}-\mathrm{OH}$ - 
BDE49 and 6-OH-BDE47. Also, 4'-OH-BDE49 and 6-OH-BDE47 had comparable but greater binding affinity for both $T_{3}$ and $T_{4}$ (Figure 16).

\subsubsection{Phylogenetic comparison of gull albumin to other vertebrates}

To my knowledge, this is the first report describing the albumin nucleotide and amino acid sequences as well as the expression and purification of THTP recALB from any gull species. In the present study, the albumin amino acid sequences from the liver of both herring and glaucous gull were found to be identical in their composition. This finding allowed us to use only one tissue as a source of a "standard" albumin protein that was representative of the Larus genus and for competitive binding. It is known that albumin is a major circulating THTP in birds, herbivorous marsupials and small eutherians (Richardson et al 1994, 1996).

Comparison of the obtained gull amino acid sequences with other vertebrates showed an evolutionary conservation of albumin nucleotides and their deduced amino acid sequences. The amino acid composition obtained for gulls in this study showed very similar sequences of $>85 \%$ with chicken albumin, which strongly suggested that the protein is highly conserved for avian species. High amino acid sequence similarities (-70\%) were observed between birds and mammals (humans), and both the mammalian and avian sequences were lower than amphibians, reptiles and fish. An exception was found with the Tuatara, a New Zealand endemic reptilian Sphenodon punctatus, which showed a $64 \%$ 
positive amino acid match with gull albumin. This finding is contrary to gull TTR that I previously demonstrated was closer in homology to reptilians than to mammalian species (Ucan-Marin et al 2009). Therefore, the use of human albumin protein to assess the $T_{3}$ or $T_{4}$ competitive binding with xenobiotic substrates is not suitable to assess $\mathrm{T}_{3}$ or $\mathrm{T} 4$ transport via albumin in avian species, but specifically in gulls (Laridae).

\subsubsection{T3 and T4 ligand binding to gull recALB versus human recALB}

I observed that gull and human recALB were clearly contrasting in the binding affinity for T3 or $\mathrm{T}_{4}$. In gull recALB, T3 had a $\sim 5$-fold greater binding affinity than $\mathrm{T} 4$, while in human recALB had greater affinity for $\mathrm{T}_{4}(\sim 4$-fold greater) relative to $\mathrm{T}_{3}$. Avian recALB had a $\sim 20$-fold greater binding affinity than human recALB relative to binding $T_{3}$. However, binding affinity was comparable for $T_{4}$ with recALB for human and gull. It has been reported that at equimolar amounts, T3 possesses several orders of magnitude higher binding affinity than $T_{4}$ in avian species (Tritsch and Tritsch 1965). It was also reported that in avian species, TRs have the highest affinity for $\mathrm{T} 3$ relative to $T_{4}$, although $T_{4}$ can trigger $\mathrm{TH}$ effects despite lower binding affinity (Decuypere et al 2005; McNabb and Wilson 1997). 
Table 3. Competitive binding parameters for recombinant gull albumin (ALB) and transthyretin (TTR) hormone transport proteins (THBPs) and $T_{3}$ or $T_{4}$, and in the presence of model $\mathrm{PCB}$ and substituted structural analogue ligands, and compared to recombinant human TTR and ALB with T3 and T4 for comparison.

\begin{tabular}{|c|c|c|c|c|c|}
\hline Compound & & $\mathrm{Ki}(\mathrm{nM})^{\mathrm{a}}$ & Relative potency $^{b}$ & $K d^{c}$ & $\begin{array}{l}\text { Maximum \% } \\
\text { competition } \\
\text { d }\end{array}$ \\
\hline \multirow[t]{2}{*}{$\mathrm{T}_{3}$} & TTR & 5.99 & 1 & 17.63 & $88 \pm 4.1$ \\
\hline & ALB & 1.12 & 1 & 3.77 & $90 \pm 2.6$ \\
\hline \multirow[t]{2}{*}{ CB187 } & TTR & 791.05 & $1.2 \times 10^{*}$ & $\begin{array}{l}188.0 \\
5\end{array}$ & $89 \pm 3.7$ \\
\hline & ALB & 15.1 & $7.4 \times 10^{-*}$ & 56.09 & $91 \pm 2.8$ \\
\hline \multirow[t]{2}{*}{ 4-MeO-CB187 } & TTR & 55.08 & 0.108 & 23.5 & $90 \pm 3.6$ \\
\hline & ALB & 4.5 & 0.248 & 5.63 & $90 \pm 2.8$ \\
\hline \multirow[t]{2}{*}{ 4-OH-CB187 } & TTR & 1.9 & 3.152 & 11.17 & $89 \pm 1.7$ \\
\hline & ALB & 0.89 & 1.258 & 2.99 & $91 \pm 2.8$ \\
\hline \multirow[t]{2}{*}{$\mathrm{T}_{4}$} & TTR & 15.74 & 1 & 27.5 & $91 \pm 3.7$ \\
\hline & ALB & 5.11 & 1 & 18.32 & $90 \pm 2.6$ \\
\hline \multirow[t]{2}{*}{ CB187 } & TTR & 91.33 & 0.171 & 36.04 & $76 \pm 5.8$ \\
\hline & ALB & 89.1 & 0.057 & 24.09 & $83 \pm 4.3$ \\
\hline \multirow[t]{2}{*}{ 4-МeO-СВ187 } & TTR & 981.15 & 0.016 & 432 & $86 \pm 2.6$ \\
\hline & ALB & 15.81 & 0.322 & 58.8 & $89 \pm 3.1$ \\
\hline \multirow[t]{2}{*}{ 4-OH-CB187 } & TTR & 13.9 & 1.19 & 10.8 & $90 \pm 1.8$ \\
\hline & ALB & 4.19 & 1.246 & 4.63 & $91 \pm 2.7$ \\
\hline \multicolumn{6}{|l|}{ Human THTPs } \\
\hline \multirow{2}{*}{$\mathrm{T}_{4}$} & TTR & 56.88 & 1 & 14.9 & $98 \pm 2.1$ \\
\hline & ALB & 7.91 & 1 & 2.77 & $91 \pm 3.9$ \\
\hline \multirow[t]{2}{*}{$\mathrm{T}_{3}$} & TTR & 207.67 & 0.27 & 60.1 & $77.3 \pm 3.7$ \\
\hline & ALB & 23.88 & 0.331 & 8.01 & $89 \pm 3.5$ \\
\hline
\end{tabular}

Note: Results presented as the mean of individual measurements, and based on $n=6$ replicates (combined triplicates on two different days). The $\pm S D$ for relative potency and maximum \% competition is based on the standard deviation of the two values comprising the ratio. See Figure 19 for competitive binding curves.

${ }^{a} K l\left(\right.$ or $\left.I_{50}\right)=K_{d}(1+T o / K a)$ (Cheng and Prusoff 1973). See Materials and Methods section for further details.

${ }^{\mathrm{b}}$ Calculated as ratio of $I C_{50}$ for a chemical $(Y / X)=E\left[Y^{A} 2\right] V(1 / X)+V(Y) E[1 / X]^{A} 2$

${ }^{c}$ The $K_{d}$ values (mean $\pm S D$ ) were determined from the slope of the linear regression line of Scatchard plots

${ }^{d}$ Percentage of competition reached at highest tested concentration $\left(1 \times 10^{5} \mathrm{nM}\right)$. 
Table 4. Competitive binding parameters for recombinant gull albumin (ALB) and transthyretin (TTR) hormone transport proteins and $\mathrm{T}_{3}$ or $\mathrm{T}_{4}$, and model PBDE and substituted structural analogue ligands.

\begin{tabular}{|c|c|c|c|c|c|}
\hline Compound & & $\mathrm{Ki}(\mathrm{nM})^{\mathrm{a}}$ & Relative potency ${ }^{b}$ & $\mathrm{Kd}^{\mathrm{c}}$ & $\begin{array}{l}\text { Maximum \% } \\
\text { competition } \\
\text { d }\end{array}$ \\
\hline \multirow{2}{*}{$T_{3}$} & TTR & 5.99 & 1 & 17.6 & $88 \pm 4.3$ \\
\hline & ALB & 1.12 & 1 & 3.75 & $91 \pm 2.8$ \\
\hline \multirow[t]{2}{*}{ BDE47 } & TTR & 529.14 & 0.011 & 189 & $88 \pm 3.8$ \\
\hline & ALB & 119.8 & $9.3 \times 10^{1 " *}$ & 67.9 & $90 \pm 1.8$ \\
\hline \multirow[t]{2}{*}{ 6-OH-BDE47 } & TTR & 69.08 & 0.07 & 8.06 & $91 \pm 2.7$ \\
\hline & ALB & 1.02 & 1.09 & 2.9 & $92 \pm 2.9$ \\
\hline \multirow[t]{2}{*}{ 4-OH-BDE49 } & TTR & 4.89 & 1.12 & 10.01 & $90 \pm 2.2$ \\
\hline & ALB & 0.79 & 1.41 & 1.98 & $89 \pm 4.3$ \\
\hline \multirow{2}{*}{$\begin{array}{l}\text { 6-MeO- } \\
\text { BDE47 }\end{array}$} & TTR & 233.7 & 0.025 & 39.6 & $90 \pm 3.5$ \\
\hline & ALB & 109.8 & 0.010 & 33.21 & $89 \pm 3.9$ \\
\hline \multirow[t]{2}{*}{$\mathrm{T}_{4}$} & TTR & 15.74 & 1 & 33.7 & $90 \pm 2.7$ \\
\hline & ALB & 5.11 & 1 & 18.32 & $90 \pm 3.5$ \\
\hline \multirow[t]{2}{*}{ BDE47 } & TTR & 89.1 & 0.176 & 221.8 & $92 \pm 4.1$ \\
\hline & ALB & 95.12 & 0.053 & $\begin{array}{l}251.2 \\
9\end{array}$ & $92 \pm 3.1$ \\
\hline \multirow[t]{2}{*}{ 6-OH-BDE47 } & TTR & 11.91 & 1.32 & 19.9 & $95 \pm 3.6$ \\
\hline & ALB & 4.99 & 1.02 & 15.43 & $94 \pm 3.9$ \\
\hline \multirow[t]{2}{*}{ 4-OH-BDE49 } & TTR & 7.68 & 2.049 & 11.57 & $96 \pm 3.9$ \\
\hline & ALB & 4.11 & 1.2433 & 5.98 & $92 \pm 2.9$ \\
\hline \multirow{2}{*}{$\begin{array}{l}\text { 6-MeO- } \\
\text { BDE47 }\end{array}$} & TTR & 54.32 & 0.289 & 117.7 & $94 \pm 3.7$ \\
\hline & ALB & 42.15 & 0.12 & $\begin{array}{l}108.0 \\
9\end{array}$ & $94 \pm 3.1$ \\
\hline
\end{tabular}

Note: Results presented as the mean of individual measurements, and based on $n=6$ replicates (combined triplicates on two different days). The $\pm S D$ for relative potency and maximum \% competition is based on the standard deviation of the two values comprising the ratio. See Figure 20 for competitive binding curves.

${ }^{a} K \backslash\left(\right.$ or $\left.I_{50}\right)=K d\left(1+T_{0} / K_{d}{ }^{*}\right)$ (Cheng and Prusoff 1973). See Materials and Methods section for further details.

${ }^{b}$ Calculated as ratio of $I C_{50}$ for a chemical $(Y / X)=E\left[Y^{A} 2\right] V(1 / X)+V(Y) E[1 / X]{ }^{A_{2}}$

${ }^{c}$ The Kd values (mean $\pm S D$ ) were determined from the slope of the linear regression line of Scatchard plots

${ }^{d}$ Percentage of competition reached at highest tested concentration $\left(1 \times 10^{5} \mathrm{nM}\right)$. 


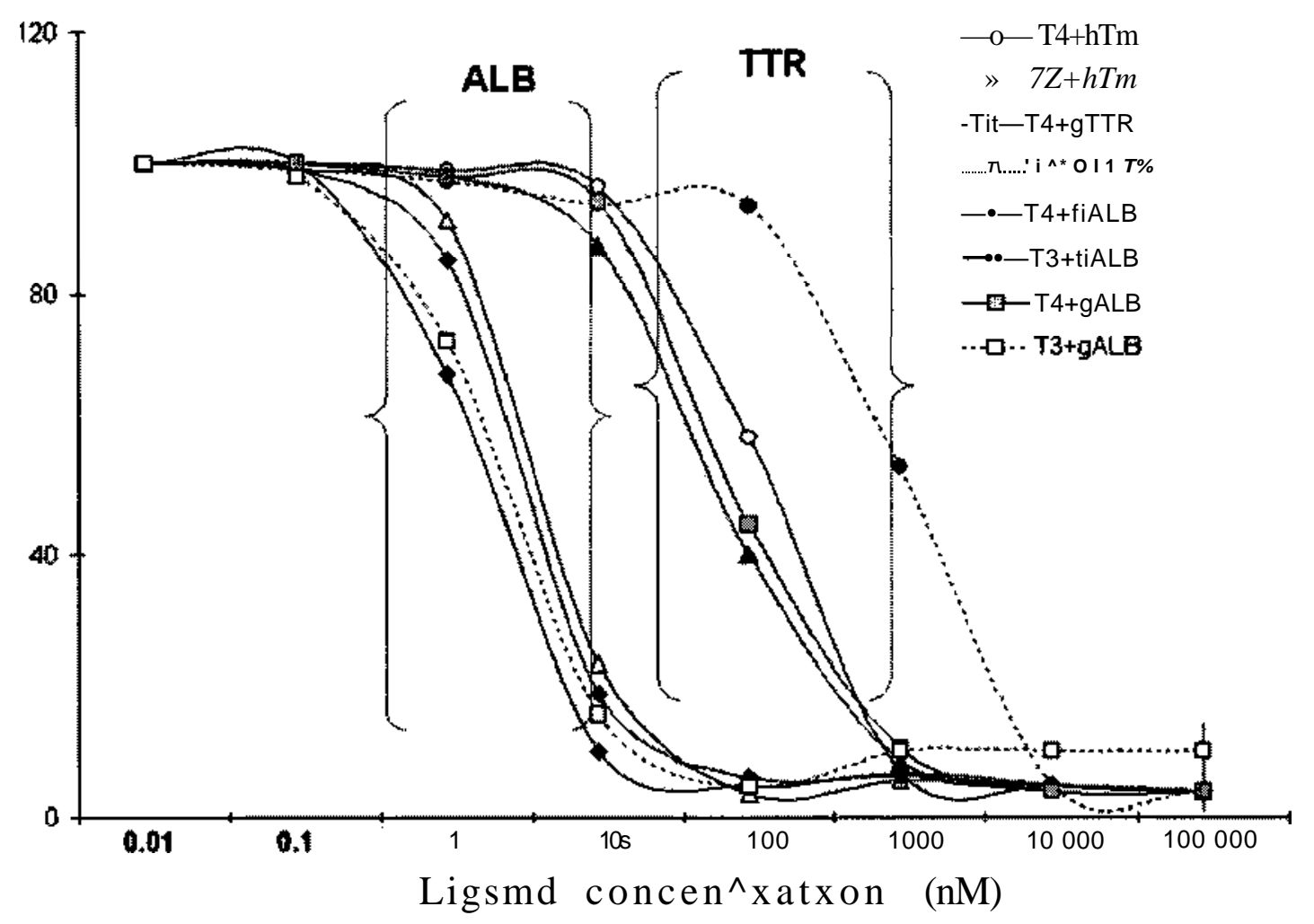

Figure 14. Concentration-dependent, competitive binding curves for recombinant gull albumin (gALB) and transthyretin (gTTR), and recombinant human hALB and hTTR, with T3 or T4 Areas in brackets denote contrasting competitive binding concentrations and parameters (Table 3) for TTR and ALB. 


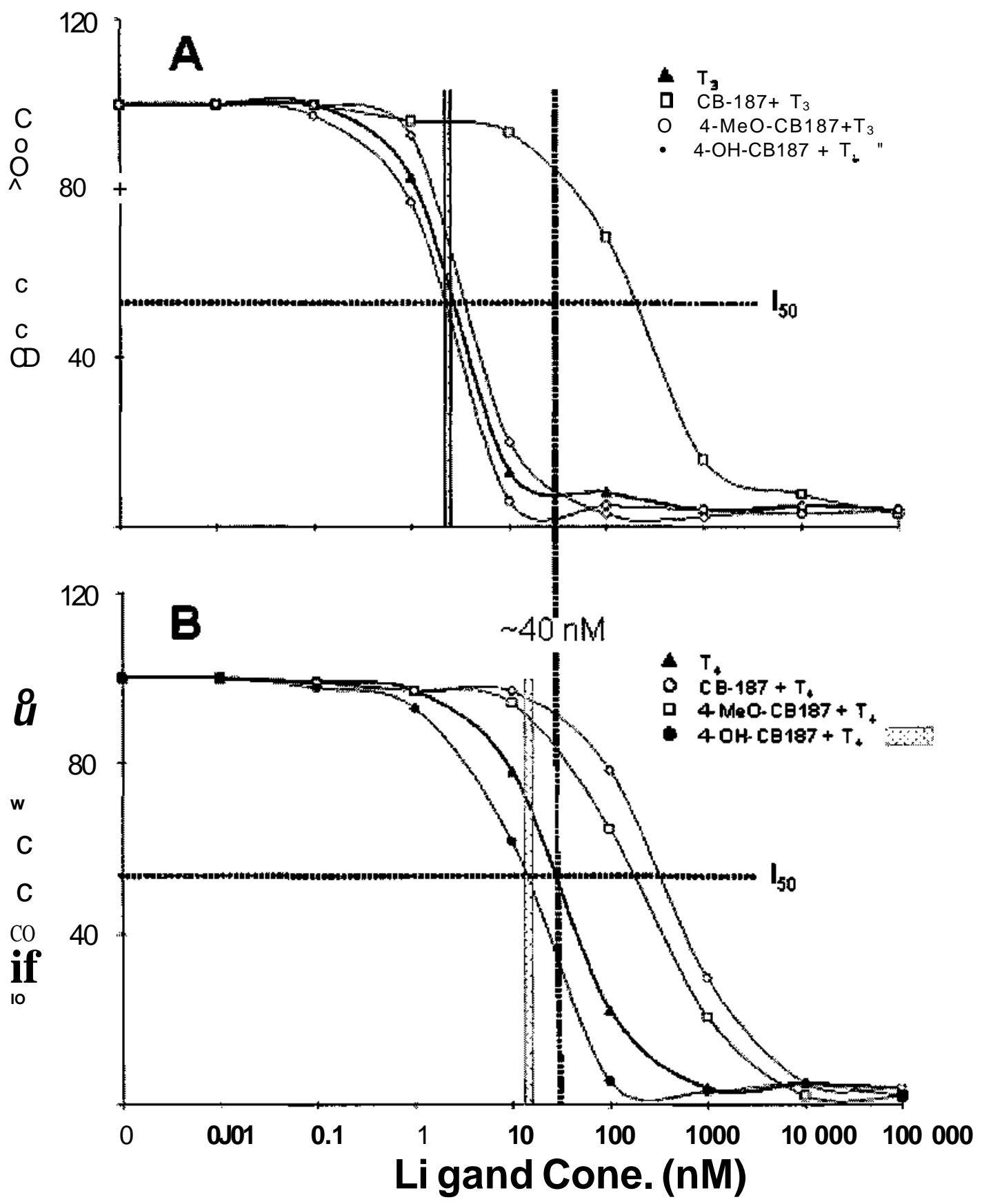

Figure 15. Concentration-dependent, competitive binding curves (percent relative to controls; $n=9$ replicates, three sets of $n=3$ triplicate sets performed on different days) for (A) $T_{3}$ and (B) $T_{4}$ displacement from gull recALB by 2,2',3,4',5,5',6-heptaCB (CB-187), 4-hydroxy-CB187 (4-OH-CB187) or 4methoxy-CB187 (4-MeO-CB187). The competitive binding parameters are listed in Table 3. Concentration ranges in brackets denote blood plasma concentrations recently reported in Norwegian (Svalbard) glaucous gulls (Letcher et al 2009; Verreaultetal. 2005a). 

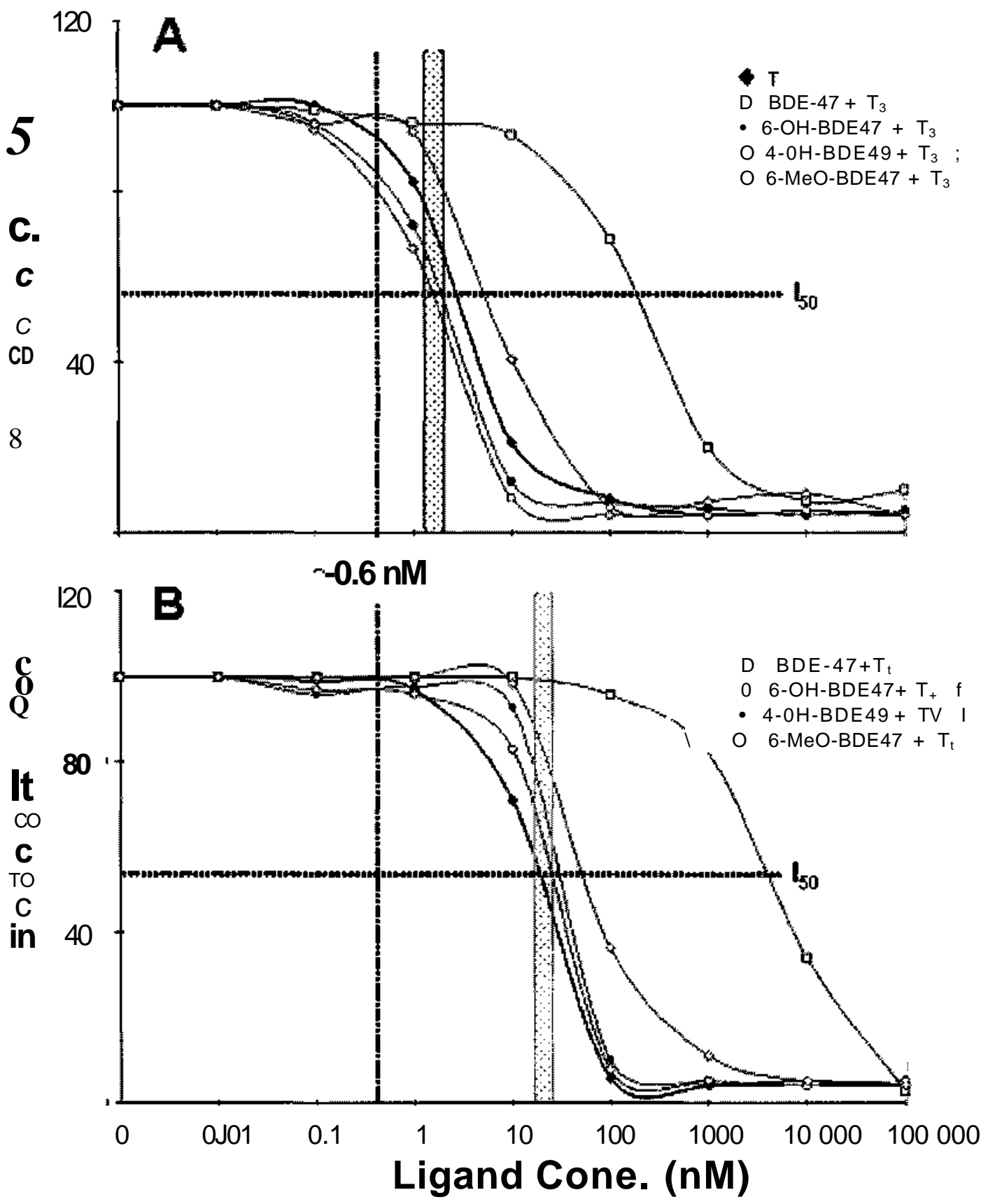

Figure 16. Concentration-dependent, competitive binding curves (percent relative to controls; $n=9$ replicates, three sets of $n=3$ triplicate sets performed on different days) for (A) $T_{3}$ and (B) $T_{4}$ displacement from gull recALB by 2,2',4,4'tetrabromoDE (BDE-47) flame retardant and 6-hydroxy-BDE47 (6-OH-BDE47), 6-methoxy-BDE47 (6-MeO-BDE47) or 4-OH-2,2',4,5-tetrabromoDE (4-OHBDE49). The competitive binding parameters are listed in Table 4. Concentration ranges in brackets denote blood plasma concentrations recently reported in Norwegian (Svalbard) glaucous gulls (Letcher et al 2009; Verreault et al 2005b). 
There are also differences among avian and other taxonomic groups with respect to $\mathrm{TH}$ binding interaction with albumin. For example, T3 is the primary $\mathrm{TH}$ bound to receptors in vivo in the few cases where this has been investigated and the physiological potency of T3 is much higher than that of T4 in mammals (Engler and Burger 1984). Also, it was reported by Bellabarba et al (1988) that avian TRs also have the highest affinity for T3 and is virtually identical to mammalian TRs. In this study, the differences in the binding affinity of THs and recALB either from gulls or human could be attributed to the complex process interaction of THs with albumin, and relative to in vivo interactions where THs are subject to a wide variety of enzyme-dependent pathways such as via deiodinases, uridine diphosphate glucuronyl-transferase UDPGT and thyroperoxidases (Miller et al 2009).

4.3.5 Competitive T3 or T4 binding of contaminant substrates with gull $\operatorname{rec} A L B$

To my knowledge, no scientific reports presently exist on xenobiotic interactions and binding affinity with recALB from a vertebrate species including birds. In fact, in the context of overall TH binding in birds, albumin is reported to be the most important THBP in chicken with circulating T4 being bound $75 \%$ to albumin, $17 \%$ to TTR and $7.5 \%$ to an a-globulin (McNabb et al 2003). However, research reports on THBP binding interactions with xenobiotics have predominantly been with TTR and mainly with human TTR protein. Results obtained in this study with 
the $\mathrm{OH}-\mathrm{PCB}$ and -PBDEs showed higher affinity to human and gull recALB compared with MeO-substituted analogues and unsubstituted PCB and PBDE congeners. This was consistent with studies on BDE47 binding with gull recTTR (Ucan-Marin et al 2009). This is also consistent with results reported by Hamers et al (2006) who screened a set of 27 individual BFRs, including 19 PBDE congeners and 6-OH-BDE47, for their relative potency of competition with $\mathrm{T}_{4}$ for binding in vitro with human TTR. Meerts et al (2001) reported no substantial human recTTR binding for 17 PBDE congeners, including BDE47, at maximum treatment concentrations of 0.25 uM. Furthermore, Meerts et al (2001) showed high binding affinity by $6-\mathrm{OH}-\mathrm{BDE} 47$ in competition with $\mathrm{T} 4$, but was of lesser potency than for other brominated phenolic substances such as tetrabromobisphenyl A (TBBPA) and 2,4,6-tribromophenol (2,4,6-TBP). Consistent with this finding, for gull and human recTTR and recALB, 4'-OHBDE49, which is para-hydroxylated was a more effective competitor than $6-\mathrm{OH}$ BDE47 or BDE47. In one rare fish example, Morgado et al (2007) reported that there was moderate competitive binding between several PBDE congeners and 6-OH-BDE47 and the displacement of $\left[{ }^{125} \mathrm{l}\right]-\mathrm{T3}$ binding to sea bream recTTR, although with a significantly higher $(p<0.001) I_{50}$ value $(700.6 \pm 40.4 \mathrm{nM})$ than for THs and at a concentration (10x) higher than the highest concentration used in the present study with human and gull recTTR. For both OH-PBDEs and $\mathrm{OH}$ PCBs, it has been proposed that for optimal THBP competitive binding (with T4), hydroxylation should exist at a para position (relative to the aromatic ring linkage), and that there be one, but preferably two, halogen substituents on 
carbons adjacent to the $\mathrm{OH}$-group (Lans et al 1993; Hamers et al 2006; Morgado et al 2007; Ucan-Marin et al 2009). It is also possible that the ligand binding differences observed in the present study, and reflected in the $\mathrm{K}_{d}$ and $K \backslash$ values for gull versus human recALB, may be attributed to differences in the amino acid sequence in the $\mathrm{TH}$ binding domain. It could also be attributed to an evolutionary divergence of human and gull albumin. Albumin also has an important role in the binding and transport of a wide variety of small molecules, and especially organic anions (e. g. bilirubin, haem, and fatty acids), which is likely species-dependent (Wallace and Wilson 1972).

The environmental relevance of the IC50 concentrations and $K$, and $K a$ values of competitive binding of $\mathrm{OH}-\mathrm{PCB}$ and $\mathrm{OH}-\mathrm{PBDE}$ ligands under study, with respect to gull recALB, is emphasized by comparisons to known circulating levels of these contaminants in free-ranging gulls. To my knowledge, there are no reports on circulating OH-PCB, OH-PBDE, PBDE or possibly MeO-PBDEs in herring gulls from the Laurentian Great Lakes. However, it has been reported that the mean concentrations of $6-\mathrm{OH}-\mathrm{BDE} 47$ and 4 '-OH-BDE49 in the plasma of male and female glaucous gulls from the Norwegian Arctic was up to $0.32 \mathrm{ng} / \mathrm{g}$ (wet weight) (Verreault et al. 2005b), which is $-0.0006 \mathrm{nM}$. In the present competitive binding with gull recALB, the same ligands effectively displaced T3 or T4 at substantially higher concentrations. Therefore, environmentally relevant $\mathrm{OH}$ PBDE concentrations are not likely to substantially affect circulating $T_{3}$ or T4 levels in wild glaucous gulls. In contrast, 4-OH-CB187 was reported at a plasma 
concentration of $17.5 \mathrm{ng} / \mathrm{g}$ ww $(-0.04 \mathrm{nM})$ in the same glaucous gulls (Verreault et al., 2005b). Furthermore, 4-OH-CB187 competitively displaced $\mathrm{T} 3$ and $\mathrm{T}_{4}$ from gull recALB at 5 to $10 \mathrm{nM}$. Therefore, 4-OH-CB187 levels in free-ranging Svalbard gulls may be high enough to effect circulating $T_{3}$ or $T_{4}$ levels. This is consistent with my recent in vitro binding studies with gull recTTR from the same samples (Ucan-Marin et al 2009).

\subsubsection{Implications ofxenobiotic modulation of thyroid hormone transport}

It is possible that the same levels of contaminants circulating in gull blood (e.g., Norwegian glaucous gulls) could effectively disrupt $\mathrm{TH}$ homeostasis due in part to the fact that albumin has a higher binding affinity than TTR and is thus more susceptible to displacement competition by hydroxylated compounds such as $\mathrm{OH}-\mathrm{PCB}$ or $\mathrm{OH}-\mathrm{PBDEs}$. It is also possible that an influence and/or change on the cellular $\mathrm{TH}$ levels and the ratio of $\mathrm{T} 3$ and $\mathrm{T} 4$ could affect $\mathrm{TH}$ homeostasis (Mendel 1989), and perhaps the TH-dependent function and affected health of exposed individuals. In birds and other wildlife, an implication of the competitive xenobiotic displacement of $\mathrm{T}_{4}$ from albumin or TTR would result in less T4 available to target tissues, and a subsequent decrease in the amount of $T_{4}$ substrate for deiodinase enzymes, including the $5^{\prime}$ deiodinases $\mathrm{DI}$ and $\mathrm{DM}$, and thus $T_{4}$ conversion to active T3 and subsequently the decreased availability of T3 to TRs (Brouwer et al 1998; Verhoelst et al 2005). In mammals for example, $\mathrm{OH}$ PCB (4-hydroxy-2,3,3', 4',5-pentachlorobipheny) binding affinity using rat liver 
cytosol and $T_{2}$ suggested that the nature of the $T_{2}$ sulfation inhibition is competitive (Schuur et al 1998).

$T_{4}$ and particularly the primary metabolically active $T_{3}$ are considered the prime controllers for the regulation of metabolic functions and thermogenesis in mammals and birds (McNabb and Fox 2003). T4 and $T_{3}$ are suspected to be involved in a partial dissipation of the mitochondrial proton electrochemical gradient that would uncouple phosphorylation from oxidation and hence produce heat. High concentrations of contaminants in mammals and birds may alter circulating TH status, basal metabolism and capacity for adaptive thermogenesis. Verreault et al (2007) recently reported for breeding glaucous gulls (from the Svalbard area), negative associations between basal metabolic rate and concentrations of PCBs, DDTs and particularly chlordanes. However, levels of THs were not associated significantly with variation of basal metabolic rate or concentrations of any blood residue levels on OH-PCBs or OH-PBDEs.

Further studies are necessary to observe effects e.g., in vitro sub cellular and $\mathrm{OHC}$ correlations at the in vivo (whole organism) level in free-ranging wildlife where TH-dependent effects are suggestive (Letcher et al 2009). There is a dearth of studies examining complex $\mathrm{OHC}$ exposures, and virtually none have addressed competitive binding with THs and THBP interaction. More experiments are needed to address the differences on species and population specifics such as TH-related effects with THBPs and confounding factors: (i) 
physiological status and timing (e.g., reproductively active); (ii) sensitivity as a function of other stressors (e.g., climate change), (iii) deleterious (chronic) effects and risks at organism or population levels.

\subsubsection{Conclusions}

The present gull albumin molecular characterization and competitive binding studies clearly showed that, although there are high amino acid sequence similarities among human and gull albumin than was observed for human and gull TTR, human albumin cannot be used as a surrogate to assess the effects on circulating THs in wildlife. Differences between human albumin and TTR for TH binding are several fold compared with gull albumin and TTR. The present study contributes with novel values of binding affinities of gull recALB binding T3 and T4, and also through a set of environmentally relevant contaminants found in circulating plasma of gulls. It was observed that $\mathrm{OH}$-metabolites either chlorinated or brominated had higher binding affinity than THs to albumin and TTR. This indicates that the combination of the more TH-like brominated diphenyl ether backbone (relative to the chlorinated biphenyl backbone), and in combination of having an $\mathrm{OH}$-group, results to more effective competitive ligand on gull hormone transport proteins relative to both T3 and T4. A ligand-binding parameter assessment for TH transport protein in gull species, and in wildlife in general, are necessary to fully understanding the potential effects in reproductive, nutritional and physiological processes that could be influenced by changes in the circulating $\mathrm{T} 4$ and $\mathrm{T}_{3}$, and subsequently $\mathrm{TH}$-dependent processes. 


\subsection{References}

Bellabarba, D., Belisle, S., Gallo-Payet, N., Lehoux, J.G., 1988. Mechanism of action of thyroid hormones during chick embryogenesis. Am. Zool. 28, 389-399.

Bernal, J., Guadano-Ferraz, A., Morte, B., 2003. Perspectives in the study of thyroid hormone action on brain development and function. Thyroid 13, 10051012.

Boas, M., Feldt-Rasmussen, U., Skakkebaek, N.E., Main, KM., 2006. Environmental chemicals and thyroid function. Eur. J. Endocrinol. 154, 599-611.

Bradford, M., 1976. A Rapid and Sensitive Method for the Quantitation of Microgram Quantities of Protein Utilizing the Principle of Protein-Dye Binding. Anal. Biochem. 72, 248-254.

Brouwer, A., Morse, D.C., Lans, M.C., Schuur, A.G., Murk, A.J., Klasson-Wehler, E.. 1998. Interactions of persistent environmental organohalogens with the thyroid hormone system: mechanisms and possible consequences for animal and human health. Toxicol. Ind. Health. 14, 59-84.

Chan, S., Kilby, M.D., 2000. Thyroid hormone and central nervous system development. J Endocrinol. 1, 1-8.

Cheng, Y.C., Prussoff, W.H., 1973. Relationship between the inhibition constant (Ki) and the concentration of inhibitor which causes 50 per cent inhibition (IC50) of an enzymatic reaction. Biochem. Pharmacol. 22, 3099-3108.

Decuypere, E., Van As, P., Van der Geyten, S., Darras, V.M., 2005. Thyroid hormone availability and activity in avian species: A review. Farm. Animal. Endocrinology. Special. Issue Part 1. Domestic Animal Endocrinol 29(1), 63-77.

Engler, D., Burger, A., 1984. The deiodination of the iodothyronines and their derivatives in man. Endocr. Rev. 5, 151-184.

Friesema, E.C., Jansen, J., Visser, T.J., 2005. Thyroid hormone transporters. Biochem. Soc. Trans. 33, 228-232.

Galtier, N., Gouy, M., Gautier, C, 1996. SEAVIEW and PHYLO-WIN: two graphic tools for sequence alignment and molecular phylogeny. Comp. Appl. Biosci. 12, 543-548.

Hakk, H., Letcher, R.J., 2003. Metabolism in the toxicokinetics and fate of brominated flame retardants-a review. Environ. Int. 29, 801-828. 
Hamers, T., Kamstra, H.J., Sonneveld, E., Murk, A.J., Kester, M.H.A., Andersson, P.A., 2006. In vitro Profiling of the Endocrine-Disrupting Potency of Brominated Flame Retardants. Toxicol. Sci. 92(1), 157-173.

Ishihara, A., Sawatsubashi, S., Yamauchi, K., 2003. Endocrine disrupting chemicals: interference of thyroid hormone binding to transthyretins and to thyroid hormone receptors. Mol. Cel. Endocrinol. 199:105-117.

Lans, M.C., Klasson-Wehler, E., Willemsen, M., Meussen, E., Safe, S., Brouwer, A., et al. 1993. Structure- dependent, competitive interaction of hydroxypolychlorobiphenyls, -dibenzo-p-dioxins and dibenzofurans with human transthyretin. Chem. Biol. Interact. 88, 7-21.

Legler, J., Brouwer, A., 2003. Are brominated flame retardants endocrine disruptors? Environ. Int. 29, 879-885.

Letcher, R.J., Klasson-Wehler, E., Bergman, A., 2000. Methyl sulfone and hydroxylated metabolites of polychlorinated biphenyls, in Paasivirta J, (Ed.), The Handbook of Environmental Chemistry,: New Types of Persistent Halogenated Compounds (, Vol 3, Part K). Springer-Verlag, Berlin, pp. 315-359.

Letcher, R.J., Bustnes, J.O., Dietz, R., Jenssen, B.M., Jorgensen, E.H., Sonne, C, Verreault, J., Vijayan, M., Gabrielsen, G.W., 2010. Exposure and effects assessment of persistent organic pollutants in Arctic wildlife and fish. Sci. Total. Environ, submitted.

McNabb, F.M.A., Wilson, M.C., 1997. Thyroid hormone deposition in avian eggs and effects on embryonic development. Amer. Zool. 37, 553-560.

McNabb, F.M.A., Fox, G.A., 2003. Avian thyroid development in chemically contaminated environments: is there evidence of alterations in thyroid function and development? Evol. Develop. 5, 76-84.

Meerts, I.A.T.M., Van-Zanden, J.J., Luijks, E.A.C., Van-Leeuwen, B.I., Marsh, G., Jakobsson, E., 2000. Potent competitive interactions of some brominated flame retardants and related compounds with human transthyretin in vitro. Toxicol. Sci. 56,95-104.

Meerts, I.A.T.M., Letcher, R.J., Hoving, S., Marsh, G., Bergman, A., Lemmen, J.G., 2001. In vitro estrogenicity of polybrominated diphenyl ethers, hydroxylated PBDEs, and polybrominated Bisphenol A compounds. Environ. Health. Perspect. 109(4), 399-407.

Mendel, CM., 1989. The free hormone hypothesis: a physiologically based mathematical model. Endocrinol. Rev. 10, 232-274. 
Mineau, P., Fox, G.A., Norstrom, R.J., Weseloh, D.V., Hallett, D.J., Ellenton, J.A., 1984. Using the herring gull to monitor levels and effects of organochlorine contamination in the Canadian Great Lakes. In: Toxic Contaminants in the Great Lakes (J.O. Nriagu and M.S. Simmons, eds), New York:John Wiley \& Sons, 425452.

Morgado, I., Hamers, T., Van der Ven, L., Power, D.M., 2007. Disruption of thyroid hormone binding to sea bream recombinant transthyretin by ioxinyl and polybrominated diphenyl ethers. Chemosphere. 69(1), 155-163.

Miller, M.D., Crofton, M.K., Rice, D.C., Zoeller, T.R., 2009. Thyroid-disrupting chemicals: Interpreting upstream biomarkers of adverse outcomes. Environ. Health. Perspect. 117(7), 1033-1041

Park, J.S., Kalantzi, O.I., Kopec, D., Petreas, M., 2009. Polychlorinated biphenyls (PCBs) and their hydroxylated metabolites (OH-PCBs) in livers of harbor seals (Phoca vitulina) from San Francisco Bay, California and Gulf of Maine. Mar. Environ. Res. 67(3), 129-135.

Richardson, S.J., Bradley, A.J., Duan, W., Wettenhall, R.E.H., Harms, P.J., Babon, J.J., 1994. Evolution of marsupial and other vertebrate thyroxine-binding plasma proteins. Am. J. Physiol. 266, 1359-1370.

Richardson, S.J., Whettenhall, E.H., Schreiber, G., 1996. Evolution of transthyretin gene expression in the liver of Didelphis virginiana and other American marsupials. Endocrinol. 137, 3507-3512.

Saitou, N., Nei, M., 1987. The neighbor-joining method: A new method for reconstructing phylogenetic trees. Mol. Biol. Evol. 4:406-425.

Schuur, A.G., Legger, F.F., Van Meeteren, M.E., Moonen, M.J.H, Van LeeuwenBol, I., Bergman, A., 1998. In vitro inhibition of thyroid hormone sulfation by hydroxylated metabolites of halogenated aromatic hydrocarbons. Chem. Res. Toxicol. 11, 1075-1081.

Stapleton, H.M., Kelly, S.M., Pei, R., Letcher, R.J., Gunsch, C, 2009. Metabolism of polybrominated diphenyl ethers (PBDEs) by human hepatocytes in vitro. Environ. Health. Perspect. 117(2), 197-202.

Tan, S.W., Zoeller, R.T., 2007. Integrating basic research on thyroid hormone action into screening and testing programs for thyroid disruptors. Crit. Rev. Toxicol. 37:5-10.

Tritsch, G.L., Tritsch, N.E., 1965. Thyroxine binding chicken serum albumin, the principal thyroxine-binding protein in the chicken. J. Biol. Chem. 240(10), 37893792. 
Ucan-Marin, F., Arukwe, A., Mortensen, A., Gabrielsen, G.W., Fox, G.A., Letcher, R.J., 2009. Recombinant transthyretin purification and competitive binding with organohalogen compounds in two gull species (Larus argentatus and Larus hyperboreus). Toxicol. Sci. 107(2), 440-450.

Ulrich, G.R., 2003. The toxicogenomics of nuclear receptor agonists. Current Opinion in Chemical Biology 7(4), 505-510.

Verhoelst, C.H.J., Van der Geyten, S., Roelens, S.A., Darras, V.M., 2005. Regulation of thyroid hormone availability by iodothyronine deiodinases at the blood-brain barrier in birds, Ann. N.Y. Acad. Sci. 1040, 501-503.

Verreault, J., Letcher, R.J., Muir, D.C.G., Chu, S.G., Gebbink, W.A., Gabrielsen, G.W., 2005a. New organochlorine contaminants and metabolites in plasma and eggs of glaucous gulls (Larus hyperboreus) from the Norwegian Arctic. Environ. Toxicol. Chem. 24, 2486-2499.

Verreault, J., Gabrielsen, G.W., Chu, S.G., Muir, D.C.G., Andersen, M., Hamaed, A., Letcher, R.J., 2005b. Flame retardants and methoxylated and hydroxylated polybrominated diphenyl ethers in two Norwegian Arctic top predators: Glaucous gulls and polar bears. Environ. Sci. Technol. 39, 6021-6028.

Verreault, J., Bech, C, Letcher, R.J., Ropstad, E., Dahl, E., Gabrielsen, G.W., 2007. Organohalogen contamination in breeding glaucous gulls from the Norwegian Arctic: Associations with basal metabolism and thyroid hormones. Environ. Pollut. 145, 138-145.

Wallace, D.G., Wilson, A.C., 1972. Comparison of frog albumins with those of other vertebrates. J. Molecul. Evol. 2, 72-86. 


\section{CHAPTER FIVE ${ }^{3}$}

\section{Organohalogens and Metabolites in the Blood and Livers of Lake Ontario Herring Gulls (Larus argentatus) and Competitive Binding of Complex Mixture Fractions With Gull Thyroid Hormone Transport Proteins In Vitro}

\subsection{Abstract}

Polychlorinated biphenyl (PCB) and polybrominated diphenyl ether (PBDE) flame retardant congeners are environmentally relevant organohalogen contaminants (OHCs), and as well as some of their hydroxylated $(\mathrm{OH})$ analogues they have been reported to have effects on thyroid hormones (THs)-dependent processes. The Great Lakes herring gulls (Larus argentatus) are a suitable bio-monitor of health ecosystems, due to their natural range, diet condition, and opportunistic feeding patterns. The main objective of this study was to examine if two selected chemical complex fractions (phenolic and neutral fractions extracted from plasma samples), were able to disrupt the affinity of TH transport proteins binding THs. In this study two colonies of Herring gulls: one from Hamilton Harbour $(\mathrm{HH})$ and from Scotch bonnet Island (SBI) where sampled, analyzed and compared. Liver and plasma ( $\mathrm{n}=10,5$ females, 5 males) were screened for OC (21 compounds), PCB (71 congeners), PBDE (15 congeners), $\mathrm{MeSO}_{2}$ - $\mathrm{CB}$ (16 congeners) and $\mathrm{HO}-$

\footnotetext{
${ }^{3}$ This chapter is in preparation to be published as a paper in a peer-reviewed journal. "UcanMarin et al, 2009. Organohalogens and Metabolites in the Blood and Livers of Lake Ontario Herring Gulls (Larus argentatus) and Competitive Binding of Complex Mixture Fractions With Gull Thyroid Hormone Transport Proteins In Vitro".
} 
PCB (33 congeners), HO-PBDE (14 congeners), 4-HO-heptachlorstyrene (4-HO$\mathrm{HpCS}$ ) and $\mathrm{MeSO}_{2}$-DDE. Other BFRs including pentabromotoluene (PBT), hexabromobenzene (HBB), 2,2',4,4',5-pentabromobiphenyl (BB-101) and total(a)-hexabromocyclododecane (HBCD) were also measured. PCA observed show a positive relation between $\mathrm{OH}-\mathrm{PCB} / \mathrm{PBDE}$ and plasma of herring gulls from $\mathrm{HH}$. This is the first report on circulating £OH-PCB, £OH-PBDE, £PBDE and £MeOPBDEs in herring gulls plasma and livers from the Laurentian Great Lakes. During the plasma preparation to analysis, complex mixtures samples from acidic and neutral fractions were isolated; then used in competitive binding assays in presence of recombinant albumin (gALB, hALB), and transthyretin from gulls and humans (gTTR, hTTR) for the binding of $\mathrm{T}_{4}$ and T3. The results showed a higher concentration of $\mathrm{OHCs}$ from $\mathrm{HH}$ than $\mathrm{SBI}$ herring gulls. Competitive binding assay shows that the neutral fraction did not have significant impact in the binding; but the phenolic fraction (containgin $\mathrm{OH}-\mathrm{PCBs}$ and $\mathrm{OH}-\mathrm{PBDEs}$ ) was able to disrupt significantly $(p<0.001)$ the binding of hTTR with $T_{4}$, hALB with $T_{4}$, and the gTTR with T3. Concluding that human $\mathrm{T}_{4}$ and T3 differ in their affinity for thyroidogenic environmental pollutants. 


\subsection{Introduction}

Modern industrial and agricultural practices in the Great Lakes basin began in the early 1940s. Since that time, thousands of chemicals and synthetic compounds have been discharged into the environment. Over 400 different man-made chemicals have been detected in Great Lakes biota; many of these are toxic, bioaccumulative and persistent (Environment Canada, 2009). Research and monitoring have focused on heavy metals such as mercury, organochlorine pesticides such as dichlorodiphenyltrichloroethane (DDT), dieldrin and mirex, and other chlorinated organics such as polychlorinated biphenyls (PCBs), hexachlorobenzene (HCB), dioxins and furans.

Endocrine disrupting compounds (EDCs) are compounds that alter normal hormone regulation (Waring et al 2005). They may be naturally occurring, such as the antioxidant flavonoids, which are found in fruits and vegetables, or may be industrial chemicals, such as some types of plasticizers, which act as environmental contaminants. Wide ranges of species, from crustaceans, fish, birds through to mammals and man, have been reported as being deregulated by EDs (Waring et al 2005). The biological actions of hormones, including oestrogens, androgens, progesterone, thyroxine and the neurosteroids pregnenolone and dehydroepiandrosterone (DHEA), are mediated via high affinity protein receptors within the target cells. DDT and other organochlorines 
carried some of the earliest work on ED effects out in bird populations affected. These compounds are now banned over most of the world but their use in the 1960s coincided with a decrease in reproductive ability of birds, particularly those at the top of the food chain such as raptors and gulls (Halldin et al 2003).

Since the early 90s it has been suggested that PCBs may be causing disruption of thyroid function in wild birds (Fox 1993). Herring gulls (Larus argentatus) exposed to pollutant loads in the Great Lakes have exhibited increased ontogenic and immunological problems compared to reference populations (Moccia et al 1986; Grasman et al 1996). Thyroid gland histopathology in gulls with high environmental PCB exposure (Moccia et al 1986) and developmental effects in chicken embryos exposed to PCBs in-ovo (Powell et al 1996) are suggestive of thyroid abnormalities. Herring gulls are considered important indicators of habitat quality because they are mostly piscivorous top predators (and commonly opportunistic feeders) that are exposed to concentrated pollutant loads through bioaccumulation in the food chain. Studies had published a strong relation between high organohalogen concentrations and depletion in thyroid hormone stores in their thyroid glands compared to gulls from reference sites (McNabb et al 2001•).

Recent work in Canada has measured contaminants present in eggs from Herring gulls from highly polluted sites in the Great Lakes, with novel reports on the PBDEs (including BDE-209 and nonabromoDE and octabromoDE gradation 
products) and several non-PBDE Brominated Flame Retardants, including BTBPE and DBDPE, from egg pools from diverse colonies (Gauthier et al 2008, Gauthier et al 2009).

However, no reports in hydroxyl- $(\mathrm{OH})$ and methoxyl (MeO)-containing analogues (i.e., 4-OH-CB187, 6-OH-BDE47, 4'-OH-BDE49, 4-MeO-CB187 and 6-MeOBDE47) reported in other gulls, had been reported for Herring gulls residing in the Great Lakes. OH-PCB compounds had been observed to disturb the competitive binding of thyroid hormones (THs) in-vitro using human TH transport proteins (Meerts et al 2000; Ucan-Marin 2009a; 2009b). This study will address if these compounds are present in detectable levels, and if they vary from two bird colonies (Hamilton Harbor $(\mathrm{HH})$ and Scotch Bonnet Island $(\mathrm{SBI}))$ at Lake Ontario.

A selected extraction of complex chemical fractions from plasma will be also addressed through competitive binding studies to observe the possibility of disruption of $\mathrm{TH}$ transport proteins when binding THs. Attention to the effect of EDCs complex chemical mixtures (Levin et al 2005; 2007) in modulation of different physiology process has increased recently. Since TH transport proteins are disrupted in presence of selected OH-PCBs (Purkey et al 2004) and $\mathrm{OH}$ PBDEs (Meerts et al 2000; Ucan-Marfn et al 2009a).

This study intend to answer if the binding of $\mathrm{THs}$ to $\mathrm{TH}$ transport proteins can also be disrupted by the presence of a chemical complex fractions [phenolic $(\mathrm{OH}-$ 
PCB/PBDE) and neutral (PCB and PBDE) containing], and the differences among human and avian $\mathrm{TH}$ transport proteins.

\subsection{Results and Discussion}

\subsubsection{Contaminants in blood and liver of herring gulls from Lake Ontario} The North American Great Lakes are an example of an ecosystem impacted by both local sources and by atmospheric deposition of contaminants transported over hundreds or thousands of kilometers (Eisenreich 1981, Baker 1997). Avian wildlife has frequently been used as an indicator of chemical pollution exposure and toxicity for assessing the health of aquatic ecosystems. PCB levels in the Great Lakes had been reported in previous reported on birds to be up to £PCBs of 59,000 ng/gr ww (Weseloh et al 1990, 1994; Haffner et al 1997). In the Great Lakes, considerable success has been achieved using fish-eating birds such as double crested cormorant (Phalacrocorax auritus) and Herring gull (Larus argentatus), as representative of contaminant exposure dynamics and in the upper trophic levels (Fox et al 1991a). Furthermore, Fox et al (1991b) noted that this species is not only representative of chemical exposures, but also of toxicological stress. Historically, herring gulls have provided an integrated measure of chemical bioavailability because of their diverse feeding habits (Weseloh et al 1990; Norstrom et al 1991; Herbert et al 1994). 


\subsubsection{Organochlorine compounds}

Plasma and liver samples were examined during this study for major organohalogens compounds and metabolites, and assessed the inter-population and -tissue of concentrations and congener patterns, for two populations of herring gulls at the far east end of Lake Ontario ( $\mathrm{SBI}$ ) and the far west end of Lake Ontario $(H H)$. No significant $(p<0.05)$ differences in contaminant levels and patterns bettwen males versus females were found among sites, when organizing data from $\mathrm{SBI}$ and $\mathrm{HH}$ was addressed.

Differences in the concentrations $(p<0.005)$ were observed for the two bird colonies in Lake Ontario; $\mathrm{HH}$ had significant higher levels of contaminants in livers and plasma than SBI herring gulls. The major organochlorine group found in herring gulls livers and plasma were ZDDT (predominantly p,p'-DDE) followed by ZPCB, ZCHL (c- and t-nonachlor) and ZCBz (mainly HCB). This pattern is consistent with results from other studies on Great Lakes Biota (Baumann and Whittle, 1988) including herring gull eggs (Gibertson, 1974; Gilman et a, 1977; Waseloh et al, 1979; Mineau et al, 1984: Weseloh et al, 1989). This is the first report of the pattern of organochlorines in the Lake Ontario using liver concentration levels of herring gulls.

The arithmetic mean concentration of the principal classes of chlorinated and brominated contaminants (and metabolites) for plasma and liver of $\mathrm{HH}$ and $\mathrm{SBI}$ 
herring gulls are listed in Table 6. I found that IPCB concentrations in plasma of $\mathrm{HH}$ gulls were 1.7-fold and significantly, higher $(\mathrm{p}<0.005)$ than the herring gull colony at SBI; while, in the livers analyzed from $\mathrm{HH}(6279 \pm 1025 \mathrm{ng} / \mathrm{g})$ were 4.5 fold $(p<0.003)$ higher than SBI. Differences in the concentration among colonies in the Lake Ontario were found, consistent with traditionally levels of organochlorine contaminants in herring gull eggs reported from 1970s and 80s had been higher in Lake Huron and in Lake Superior compared to Lake Erie or the lake Ontario (Mineau et al 1984). Differences in the feeding habits of the two colonies sampled in this study can be attributed to the higher concentrations of IPCB found in $\mathrm{HH}$ compared to SBI. Hebert et al (1999) reported that stable nitrogen $\left(d^{15} \mathrm{~N}\right)$ and carbon $\left(\mathrm{d}^{13} \mathrm{C}\right)$ isotope measured in lipid-free homogenates of herring gulls eggs collected from the Laurentian Great Lakes from 1974 to1995 had significant differences in gull trophic positions found among diverse colonies. The authors attributed the results to the differing proportions offish in the diets of gulls from the various colonies; where aquatic foods available to gulls had greater $d^{15} \mathrm{~N}$ values than terrestrial foods, concluding that terrestrial foods, particularly waste and urban garbage, were more enriched in ${ }^{13} \mathrm{C}$ than aquatic feeding patterns. As the proportion of fish in the diet decreased, the fraction consisting of terrestrial food increased, resulting in an increase in $d^{13} \mathrm{C}$ values and a decline in $d^{15} \mathrm{~N}$ values. Fish availability besides the stability physicochemical properties of compounds and water surrounding the colonies of gulls are possibly main factors in the higher concentration found in $\mathrm{HH}$ site. 
This is the first report of concentrations of ZPCBs for livers inLake Ontario, then comparison of levels found are not comparable iwht published data, however levels found in this study are similar to the data published for arctic birds. Mallory et al (2005) analyzed liver tissues of glaucous gulls, (Larus hyperboreus) from Qikiqtarjuaq, (Nunavut, Canada) with values of $8,013 \mathrm{ng} / \mathrm{g} \mathrm{ww}$.

In this study, the dominant congeners were PCB 138, 153, 180 and 118, trend that repeats the dominant congeners of PCBs in plasma and liver of herring gull from Lake Ontario. The dominant congeners PCB 153 was found in the samples of this study in concentrations of $169 \mathrm{ng} / \mathrm{g}$ ww for plasma and $1619 \mathrm{ng} / \mathrm{g} \mathrm{ww}$ for liver in $\mathrm{HH}$ and herring gull. Concentrations for $\mathrm{SBI}$ site were 29.02-ng/g ww for plasma and $325 \mathrm{ng} / \mathrm{g} w \mathrm{w}$ for the liver. The most dominant congeners reported in herring gulls at Lake Ontario during 1981 (Haffner et al, 1997) were PCB 138, 180, 153 and 118 and during 1992 with a decrease in the concentrations, but with the same pattern of PCB congeners $(118,153,180$ and 138).

Concentrations observed for PCB-138 were $162 \mathrm{ng} / \mathrm{g}$ ww on plasma and 1638 ng/g ww on liver of Herring gulls at $\mathrm{HH}$ site. Gulls at SBI location had $29.3 \mathrm{ng} / \mathrm{g}$ ww on plasma and $278 \mathrm{ng} / \mathrm{g}$ ww in livers. PCB-180 in plasma of herring gulls from $\mathrm{HH}$ had concentrations of $94.12 \mathrm{ng} / \mathrm{g} \mathrm{ww}$ and $929 \mathrm{ng} / \mathrm{g}$ for the liver, while samples from SBI were $19.06 \mathrm{ng} / \mathrm{g}$ ww on plasma and $173 \mathrm{ng} / \mathrm{g}$ ww in liver. The next PCBs in order of concentration detected were PCB118, 187, 170/190 and $70 / 76$. 
Since the early 1970s, the Canadian Wildlife Service has been monitoring organochlorines, including DDE and PCBs, in wildlife (Norstrom, 1988). Eggs of fish-eating birds have been the main monitoring tissue, and in 1974, the herring gull was adopted as the main avian species for monitoring organochlorine contaminants in the Great Lakes (Mineau et al 1984). £DDT $j_{n}$ this study was observed 3.2-fold higher on the plasma concentration of herring gulls from $\mathrm{HH}$ site than SBI. Comparing the livers of herring gulls from $\mathrm{HH}$ with SBI, they had 3.4-fold higher concentrations (Table 6).

The compounds in order of concentration detected were: p,p'-DDE with 296.3 $\mathrm{ng} / \mathrm{g}$ ww for plasma samples from herring gulls at $\mathrm{HH}$ site and $76.01 \mathrm{ng} / \mathrm{g}$ for plasma on SB gulls. Livers from $\mathrm{HH}$ site had $2486 \mathrm{ng} / \mathrm{g}$ ww, and from SBI had $623.5 \mathrm{ng} / \mathrm{g} \mathrm{ww}$. These concentrations detected are very low compared to previous report for Herring gulls eggs from Hamilton Harbour in 1989 (Weseloh et al, 1995) where the authors registered DDE cocentrations of $56,000 \mathrm{ng} / \mathrm{g}$ ww. For the $p, p$-DDT concentrations of $19.72 \mathrm{ng} / \mathrm{g}$ ww for plasma in gulls from $\mathrm{HH}$ site was observed, and $20.5 \mathrm{ng} / \mathrm{g}$ ww for SB gulls. The livers from $\mathrm{HH}$ site had levels of $477 \mathrm{ng} / \mathrm{g} \mathrm{ww}$ and SBI had $225 \mathrm{ng} / \mathrm{g}$. Regarding the p,p'-DDD found in plasma, were detected levels of $1.91 \mathrm{ng} / \mathrm{g} \mathrm{ww}$ on $\mathrm{HH}$ site and $0.37 \mathrm{ng} / \mathrm{g}$ ww for herring gulls residing at SBI. Liver concentration levels of p,p'-DDD were 15.55 $\mathrm{ng} / \mathrm{g}$ ww for Hamilton site and $2.38 \mathrm{ng} / \mathrm{g}$ ww for the herring gulls at Scotch Bonnet Island. 
Table 6. Arithmetic mean, Standard Error (SE) and Data Range of concentrations of ${ }^{\wedge} \mathrm{compound}$ identified in plasma and liver of Herring gulls from Hamilton Harbour (HH) and Scotch Bonnet Island (SB).

\begin{tabular}{|c|c|c|c|c|}
\hline \multirow[t]{2}{*}{$\mathrm{ng} / \mathrm{g}$ ww } & \multicolumn{2}{|c|}{ Plasma } & \multicolumn{2}{|l|}{ Liver } \\
\hline & $\mathrm{HH}$ & SB & $\mathrm{HH}$ & SB \\
\hline \multicolumn{5}{|l|}{$£ P C B s^{a}$} \\
\hline Mean \pm SE & $787 \pm 275$ & 4651192 & $6279 \pm 1025$ & $1537 \pm 387$ \\
\hline Range & $68-3402$ & $83-2013$ & $1121-45568$ & $617-8174$ \\
\hline \multicolumn{5}{|l|}{$10 H$ PCBs ${ }^{b}$} \\
\hline Mean \pm SE & $39.3 \pm 9.4$ & $22.7 \pm 6.5$ & $38.3 \pm 11.8$ & $16.7 \pm 6.1$ \\
\hline Range & ND-86.5 & ND-74.3 & ND-91.5 & ND-116 \\
\hline \multicolumn{5}{|l|}{ IPBDEs $^{c}$} \\
\hline Mean \pm SE & $166 \pm 37.2$ & $58.95 \pm 11.9$ & $1857 \pm 198.5$ & $665 \pm 181.7$ \\
\hline Range & $4.9-314$ & $2.85-219$ & $21.8-3451$ & $19.8-2178$ \\
\hline \multicolumn{5}{|l|}{$\mathrm{ZOH}^{\mathrm{PBDEs}}{ }^{\mathrm{d}}$} \\
\hline Meant SE & $1.1 \pm 0.62$ & $0.34 \pm 0.12$ & $0.66 \pm 0.21$ & $0.56 \pm 0.17$ \\
\hline Range & ND-5.9 & ND-6.8 & ND-10.1 & ND-6.4 \\
\hline \multicolumn{5}{|l|}{$\mathrm{IMeO}$ PBDEs ${ }^{\mathrm{e}}$} \\
\hline Mean \pm SE & $4.1 \pm 1.7$ & $2.87 \pm 0.92$ & $37.8 \pm 5.2$ & $22.5 \pm 4.8$ \\
\hline Range & $0.68-15.4$ & $0.83-12.01$ & $10.2-45.5$ & $6.1-38.7$ \\
\hline \multicolumn{5}{|l|}{$£ \mathrm{CHL}^{*}$} \\
\hline Mean \pm SE & $8.3 \pm 2.4$ & $1.62 \pm 0.65$ & $79.5 \pm 18.8$ & $18.2 \pm 4.1$ \\
\hline Range & ND-26.5 & ND-14.3 & ND-151.5 & ND-56.7 \\
\hline \multicolumn{5}{|l|}{$\mathrm{ICBz}^{9}$} \\
\hline Meani SE & $21.6 \pm 4.2$ & $3.31 \pm 0.96$ & $16.45 \pm 5.5$ & $3.4 \pm 1.7$ \\
\hline Range & ND-41.2 & ND-21.9 & ND-45.1 & ND-23.8 \\
\hline \multicolumn{5}{|l|}{ IDDTs $^{h}$} \\
\hline Mean \pm SE & $316.43 \pm 61.1$ & $98.13 \pm 23.68$ & $2978 \pm 521$ & $855 \pm 247$ \\
\hline Range & $10.23-915$ & $12.23-438.56$ & $95.68-5213$ & 89.6-2489 \\
\hline \multicolumn{5}{|l|}{$£$ Mirex' } \\
\hline Mean \pm SE & $187 \pm 39.13$ & $42.01 \pm 9.21$ & $1477 \pm 352$ & $373.2 \pm 97.45$ \\
\hline Range & $15.9-356$ & 13.8-102 & $23.6-2563$ & $29.4-856$ \\
\hline
\end{tabular}

a IPCB: sum of PCB 18, 17, 16/32, 31, 28, 33/20, 22, 52, 49, 47/48, 44, 64/41, 74, 70/76, $95,66,56 / 60,92,101 / 90,99,97,87,85,110,151,149,118,146,153,105,141,130,176$, $137,138,158,178,187,183,128,167,174,177,202,171,156,200,157,172,180$, 170/190, 189, 199, 196/203, 208, 194, 195 and 206, 207; ' 1 OH PCBs: Sum of 4'-OH-CB79, 4-OH-CB146, 4'-OH-CB177, 4-OH-CB187, 4'-OH-CB199, 4'-OH-CB201, 4'-OH-CB202; ' IPBDE: sum of PBDE 47, 99, 100, 138.154/BB153, HBCDD, 153, and 183; ${ }^{d} \mathrm{EOH}$ PBDEs: Sum of 6'-OH-BDE49, 6-OH-BDE47, 3-OH-BDE47, 4'-OH-BDE49; ' ${ }^{2}$ ¿MeO PBDE: Sum of 6-MeO-BDE47and 5-MeO-BDE47 3-MeO-BDE47, 4-MeO-BDE49; ICHL: Octachlorostyrene, Heptachlor.epoxide, Oxychlordane, t-Chlordane, c-Chlordane, tNonachlor; $9 \mathrm{CBz}$ : Sum of 1,2,3,4-Tetrachlorobenzene, 1,2,4,5-Tetrachlorobenzene, Pentachlorobenzene, a-Hexachlorocyclohexane, Hexachlorobenzene; ${ }^{h}$ EDDTs: p,p'-DDE, p,p'-DDD and p,p'-DDT;' £Mirex: Photomirex and Mirex 
There are other recent new data of DDT in herring gulls livers and plasma from Lake Ontario, so to compare the concentration levels found in plasma of herring gulls a comparison was made with recent publications overseas. Concentrations detected by Verboven et al (2009) in plasma of gulls (Glaucous) were of $310.1 \pm 50.8 \mathrm{ng} / \mathrm{g}$ ww from Bjornoya Norway. Verboven et al (2009) values were similar to the data obtained from Hamilton Harbour site. In another study, Mallory et al (2005) reported a £DDT of $4263 \mathrm{ng} / \mathrm{g}$ ww for livers of glaucous gulls from Qikiqtarjuaq (Nunavut Canada). These values are 1.5-fold higher than the values for $\mathrm{HH}$ herring gulls livers, and 5-fold higher than the livers from SBI. The same pattern repeats in this data, agreeing to previous data published for herring gull eggs by Weseloh et al (1995) that published that Cis-nonachlor and T-nonachlor as the main contaminants of $£ \mathrm{CHL}$ Differences were observed when comparing values, because data in this study was significantly lower than the levels reported from eggs at Hamilton Harbour in 1989 where values for t-Nonachlor were 840 $\mathrm{ng} / \mathrm{g}$ ww and c-Nonachlor had $620 \mathrm{ng} / \mathrm{g}$ ww. In addition, data dotaned for $£ \mathrm{CHL}$ were similar with recently reported concentrations overseas by Verboven et al (2009); where the analysis of $£ C H L$ in plasma of glaoucous gulls from Bjornoya, Norway was $15.9 \pm 2.7 \mathrm{ng} / \mathrm{g}$ in females and $39.0 \pm 12.0 \mathrm{ng} / \mathrm{g}$ for males.

Comparison of $£ C B z$, for gulls from $\mathrm{HH}$ and $\mathrm{SB}$ showed that plasma of herring gulls from $\mathrm{HH}$ was 6.5 -fold higher than $\mathrm{SBI}$ and concentrations from herring gull livers from $\mathrm{HH}$ were 4.8-fold higher than SBI. The dominant congeners analyzed in this group of chemicals where hexachlorobenzene and pentachlorobenzene. 
Concentrations of hexachlorobenzene in plasma were $19.6 \mathrm{ng} / \mathrm{g} \mathrm{ww}$ for herring gulls at $\mathrm{HH}$ and $2.97 \mathrm{ng} / \mathrm{g}$ ww for gulls from SBI. Liver concentrations were 14.56 $\mathrm{ng} / \mathrm{g} \mathrm{ww}$ for $\mathrm{HH}$ site, and $3.12 \mathrm{ng} / \mathrm{g}$ ww for herring gulls from SBI. Values of pentachlorobenzene found in this study are significant low compared to the values (520 ng/g ww) reported in 1989 for herring gulls eggs at Hamilton Harbour by Weseloh et al (1995). Data of $£ C B z$, from Mallory et al (2005) in glaucus gull livers from Qikiqtarjuaq; (Nunavut Canada) reported concentrations of $495 \mathrm{ng} / \mathrm{g}$ ww; data that is 30 -fold higher than the values that I observed for herring gull livers at $\mathrm{HH}$, but similar to the concentrations reported in 1995 for Hamilton Harbour herring gull eggs (Weseloh et al 1995).

Levels of £Mirex where mostly conformed for Photomirex and Mirex, where XMirex on plasma of $\mathrm{HH}$ gulls was 4.5 -fold higher than the levels found in SBI gulls. Level values in livers of $\mathrm{HH}$ gulls were 4-fold higher than the gulls sampled from SB. Mirex was the dominant compounds with the highest concentration in liver and plasma in both sited sampled followed by Photomirex. Mirex concentration found in this study differs from Mirex concentrations reported in herring gull eggs at Hamilton Harbour with $8800 \mathrm{ng} / \mathrm{g}$ (Weseloh et al 1995). The concentration found in this study of photomirex were significantly lower than concentrations for herring gull eggs reported for $\mathrm{HH}$ site in 1989, where Weseloh et al (1995) had values of $3590 \mathrm{ng} / \mathrm{g}$ ww. However, £Mirex concentration levels in this study in livers from SBI were similar to values reported by Mallory et al, (2005) for the livers of glaucus gulls (324 ng/g ww) at Qikiqtarjuaq, Canada. Data 
from herring gull livers from $\mathrm{HH}$ in this study were 4.5-fold higher than SBI gulls and also higher than gulls analyzed by Mallory et al, (2005) from Qikiqtarjuaq.

Some studies had reported declines in most of the legacy persistent organic pollutants (e.g. PCBs, DDT), with data over the recent decades that have been documented a number of seabird species throughout the marine environment of the northern hemisphere; e.g. gannets (Sula bassana) from western Scotland (Alcock et al 2002), common terns (Sterna hirundo) from the Wadden Sea (Becker et al 2001), guillemots/common murres \{Uria aalge) and little terns \{Sterna albifrons) from the Baltic Sea (Thyen et al 2000), black guillemots (Cepphus grylle) from Iceland (Olafsdottir et al 2005), common and thick-billed murres from Alaska (Vander Pol et al 2004), and double-crested (Phalacrocorax auritus) and pelagic (Phalacrocorax pelagicus) cormorants from the Canada's west coast (Harris et al 2005).

The decrease of the OCs contaminants in lake Ontario differ from other pattern found in avian species from emerging industrial economies, recent data published by Chen et al (2009) shows new data of organochlorine contamination in Chinese terrestrial birds of prey, where the authors reported the presence of PCBs, DDTs and other organochlorine pesticides in various raptors from northern China in extremely high quantities ( $\mathrm{mg} / \mathrm{kg}$ wet weight basis). One example of the top food-chain bioaccumulation is the Eurasian sparrow hawks (Accipiter nisus) where DDE levels exhibited the highest concentrations among 
targeted compounds $(23.5-1020 \mathrm{mg} / \mathrm{kg}$ lipid weight). This concentration was observed even the bird does not reside in China, Chen et al (2009) related this level due to their stopover in southeastern China, where high DDT and dicofol applications have been recently documented.

Low levels of OCs were observed in this study of plasma and liver of Herring gulls compared to historical levels detected in eggs from Lake Ontario in the 70 s and $80 \mathrm{~s}$, however, has been documented that herring gulls are strong to be resistant and with high tolerance to contaminants. Ewins et al (1992) found little evidence of impaired reproduction attributable to organochlorine contamination in Lake Huron in 1980. Weseloh et al (1990) reported that productivity in Lake Erie in 1979 was normal at widely separated colonies, despite widely differing levels of organochlorine contaminantion. There was not a significant correlation between increased PCB loading and decreased reproductive output in Lake Superior Herring gulls in 1983 (Weseloh et al 1994).

\subsubsection{Brominated Compounds}

For the brominated concentrations found in this study, it was observed that ZPBDEs in plasma of herring gulls $\mathrm{HH}$ site was 2.8-fold higher than SBI (Table 6, appendix I), with levels of $166 \mathrm{ng} / \mathrm{g} \mathrm{ww}$ in plasma for $\mathrm{HH}$ site and $58.95 \mathrm{ng} / \mathrm{gr}$ ww for SBI. Livers analyzed from herring gulls collected at $\mathrm{HH}$ had 2.1-fold higher than SBI, the concentrations found were $1857 \mathrm{ng} / \mathrm{g} \mathrm{ww}$ for livers of $\mathrm{HH}$ and 665 ng/g ww for SBI. These concentrations are higher than previous data published 
by Norstrom et al (2002) with values of $755 \mathrm{ng} / \mathrm{g} \mathrm{ww}$ in eggs of herring gulls from Hamilton Harbour, and levels of 1003 ng/g ww for Toronto Harbour; and 530 ng/g ww in Snake Island; all three sites inside the Lake Ontario, Canada. Values in this investigation are similar with Norstrom et al (2002) where the authors analyzed the trend of £PBDEs increasing concentration without interruption since 1981 to 2000 . Where in 1981 the average concentration was $9.4 \mathrm{ng} / \mathrm{g} \mathrm{ww}$, and by 2000 the concentration was $530 \mathrm{ng} / \mathrm{g}$ at Snake Island in Lake Ontario.

The most dominant PBDE congeners observed in this study in importance of concentration detected were BDE 153 with concentrations in plasma of 49.29 $\mathrm{ng} / \mathrm{g}$ ww for gulls at $\mathrm{HH}$ and $6.51 \mathrm{ng} / \mathrm{g}$ ww of SBI. Liver concentrations found in $\mathrm{HH}$ were $510 \mathrm{ng} / \mathrm{g} \mathrm{ww}$ and $71.52 \mathrm{ng} / \mathrm{g}$ for SBI. This differs from values reported by Norstrom et al (2002) where the most dominant congener was BDE-47 for Hamilton Harbour and for Toronto Harbour; however, for the Snake Island in the Lake Ontario these authors reported the most dominant congener to be BDE-99.

The next PBDE congener of relevance due to its concentration was BDE-99 where levels in plasma found in herring gulls from $\mathrm{HH}$ site had $43 \mathrm{ng} / \mathrm{g} \mathrm{ww}$, and $11.41 \mathrm{ng} / \mathrm{g}$ ww for gulls at SBI. The BDE-99 concentration in livers was $510 \mathrm{ng} / \mathrm{gr}$ ww for $\mathrm{HH}$ gulls and $122 \mathrm{ng} / \mathrm{g}$ ww for herring gull liver from SBI. These values are consistent with a previous trend published by Norstrom et al (2002), which reported PBDE-99 as the second most dominant congener in Hamilton Harbour and Toronto Harbour after analyzing eggs of Herring gulls. 
The compound BDE-154/BB-153 was detected with $32.17 \mathrm{ng} / \mathrm{g}$ ww at plasma samples from $\mathrm{HH}$ site, and 4.31 for SBI. Liver concentrations were $317 \mathrm{ng} / \mathrm{g} \mathrm{ww}$ on $\mathrm{HH}$ site and $52.23 \mathrm{ng} / \mathrm{g}$ ww for SBI herring gulls. The next congener in order of importance and concentrations was BDE-100 and -47 . BDE-100 had 31.71 $\mathrm{ng} / \mathrm{g}$ ww on plasma from $\mathrm{HH}$ site and $8.9 \mathrm{ng} / \mathrm{g}$ ww for SBI. In livers, the BDE-100 had $332 \mathrm{ng} / \mathrm{g}$ ww for $\mathrm{HH}$ site and $97.63 \mathrm{ng} / \mathrm{g}$ ww for SBI.

BDE-47 was the only compound detected with higher concentrations in plasma and liver from SBI than $\mathrm{HH}$ site (Table 6, Appendix I). This value is different that the previous data published in eggs from Hamilton Harbour, where commonly, the sites of Hamilton and Toronto Harbour had higher BDE-47 levels (Norstrom et al 2002). In this study, it was also observed that SBI site had higher concentrations of BDE-47 than $\mathrm{HH}$, in liver and in plasma.

Concentrations of $28.12 \mathrm{ng} / \mathrm{g}$ ww for SBI herring gull plasma, and $20.01 \mathrm{ng} / \mathrm{g} \mathrm{ww}$ for $\mathrm{HH}$ site were observed. Liver concentrations from SBI were $312.54 \mathrm{ng} / \mathrm{g} \mathrm{ww}$ and $268.63 \mathrm{ng} / \mathrm{g}$ ww for $\mathrm{HH}$. The pattern of the five most dominant congeners found in this study were BDE $153>99>154>100>47$; contrary to a traditional pattern found in Hamilton and Toronto Harbour of BDE 47>99>100>153>154. Observing that the pattern of congener varies among tissues analyzed, in this case liver and plasma from this study with eggs from previous reports. 
Sellstrom et al (2003) mention that concentrations of BDE-47, BDE-99, and BDE100 declined after peaking in the mid- to late-1980s. But also PBDE concentrations have increased exponentially in wild birds in the North American Great Lakes from 1981 to 2000 (Norstrom et al., 2002) The PBDE congeners found in wild herring gulls (Larus argentatus) were predominantly the 2,2',4,4'tetrabromoDE (BDE-47), 2,2',4,4',5-pentabromoDE (BDE-99), 2,2',4,4',6pentabromoDE (BDE-100), 2,2',4,4',5,5'-hexabromoDE (BDE-153), 2,2',4,4',5,6'hexabromoDE (BDE-154), and 2,2',3,4,4',5',6-heptabromoDE (BDE-183) (Norstrom et al 2002). In addition to these congeners, in this study was observed detection levels of decabromoDE 209 in liver and plasma in SBI and $\mathrm{HH}$ sites, compound previously thought not to accumulate in living organisms (Lindberg et al 2004). A swith in diet containgin BDE-47, probably in fish. In a European study by Jaspers et al (2005) BDE-47 was reported the most abundant congener in fish that mainly feed on fish such as heron (Ardea cinerea) and grebe (Podiceps cristatus), suggesting that BDE 47, 99 and 153 were equally important in the terrestrial species; while BDE-183 and BDE 209 were only measured in the terrestrial birds. These results indicate that terrestrial birds may be more exposed to higher brominated BDE congeners than aquatic species. A different feeding pattern among colonies of herring gulls at $\mathrm{HH}$ and $\mathrm{SBI}$, and a decrease in fish diet, could be the differences in the patterns observed in this study.

Despite the high concentrations of PBDEs found in wildlife tissues, brief information is available related the possible toxic effects of these chemicals in 
birds and in wildlife in general. Current reviews provide some wildlife toxicity data but there have been no studies to date investigating possible PBDE -induced immunomodulation or other physiological effects on birds (de Wit 2002; Darnerud 2003). Immunological effects have also been suggested for PBDE exposure, which were used as constituents in commercial flame retardants (Lipson, 1987). Modulation effects on endocrine systems in wildlife may also occur because of PBDE exposure and or subsequent OH-PBDE metabolite formation (Darnerud 2003; Legler and Brouwer 2003).

\subsubsection{Novel compounds detected in Herring gulls at Great Lakes}

There are non previous reports of the presence of $\mathrm{OH}-\mathrm{PCBs}$ and $\mathrm{OH}-\mathrm{PBDEs}$ in Great Lakes Herring gulls. Concentrations of $\mathrm{OH}$ PBDEs/PCBs were found in plasma and liver from both sites sampled at Lake Ontario. The ${ }^{\wedge} \mathrm{OH}-\mathrm{PBDEs}$ and -PCBs detected in the liver and blood from $\mathrm{HH}$ and SBI gulls are listed in Table 6 and Appendix I. In reference to the chlorinated compounds the two most important compounds detected in this study were $4-\mathrm{OH}-\mathrm{CB} 187$ and $4-\mathrm{OH}-$ CB146. This is the first report of ZOH-PCBs in herring gulls at the Great Lakes. Hydroxylated metabolites from brominated compounds in this study had lower concentrations than the PCBs. According to their concentrations detected it was observed that the most dominant congeners were $4-\mathrm{OH}-\mathrm{BDE} 49$ and $6-\mathrm{OH}-$ BDE47, followed by 6-OH-BDE49 and 6-OH-BDE49. 
Levels detected in this study are lower than values published by Verreault et al (2007) where the ZOH-PCB for glaucous gull from Svalbard had $52.5 \mathrm{ng} / \mathrm{g}$ ww in plasma and $28 \mathrm{ng} / \mathrm{g}$ ww in livers. In addition, data in this study was higher than recent values reported by Verboven et al (2009) for glaucous gulls from Bjornoya Norway where the authors reported $4.2 \mathrm{ng} / \mathrm{g} \mathrm{ww}$ for females and $14.9 \mathrm{ng} / \mathrm{g}$ ww in males. For glaucous gull plasma from Bjomoya Norway (Verboven et al 2009) 2$\mathrm{OH}-\mathrm{BDE}$ concentration were $1.7 \pm 0.8 \mathrm{ng} / \mathrm{g} \mathrm{ww}$ for females and $2.2 \pm 0.8 \mathrm{ww} \mathrm{ng} / \mathrm{g}$ for males.

Methoxylated brominated diphenyl ethers feMeO-PBDEs) observed in this study was higher in plasma from $\mathrm{HH}$ than $\mathrm{SB}$, and concentrations in livers of $\mathrm{HH}$ were 1.6-fold higher than SB (see Table 6 and Appendix I). The two dominant methoxylated metabolites observed in this analysis in order of importance by their concentration were 6-MeO-BDE47 and 5-Me- BDE47.

Current understanding of PCB biotransformation and detoxification mechanisms suggests that the compounds found in the phenolic fraction such as $\mathrm{OH}-\mathrm{PCB}$ are retained in vertebrates mainly are derived from enzyme-mediated processes (e.g., cytochrome P450 (CYP) monooxygenases), whereas the OH-PBDEs may be formed via metabolism of major PBDEs and/or accumulated as naturallyoccurring compounds (e.g., via formation in algae and sponges) (Hakk and Letcher 2003; Letcher et al 2000; Malmberg et al 2005; Stapleton et al 2009). 


\subsubsection{Competitive binding of Complex Mixtures}

To address if the concentrations of OH-PCBs/PBDEs contained in the phenolic fraction (Table 6) are able to disrupt normal competitive binding among hormone transport gull (and human rTTR and rALB). In vitro assays were performed to evaluate the competitive binding of the chemical extractions (neutral and phenolics) to observe if there was an increase or decrease in the natural affinity of $T_{4}$ and $T_{3}$ to bind albumin and TTR. The results obtained show that neutral fraction (Figure 17), did not present significant differences ( $p>0.06)$; however, an apparent high binding was observed among T4 and the neutral fraction in binding competition with recombinant human albumin.

The phenolic fraction (Figure 18) had more competitive binding affinity differences with TH transport proteins. Phenolic fraction with human TTR was significantly able to disrupt $(p<0.001)$ the T4 binding increasing to $143 \%$ the binding affinity of the assay, and the same phenolic fraction with T3 in presence of human TTR had $108 \%$ count per minute. Phenolic complex mixtures competing with Gull TTRs had no significant differences $(p>0.06)$ in the binding of $\mathrm{TH}$; however, an apparent increase in the displacement of T4 was observed compared to control. Recent in vitro studies have shown that hydroxylated metabolites of PBDEs bind with high affinity to thyroid hormone transport protein (i.e., transthyretin) (Meerts et al 2000) and bind to thyroid hormone receptors TRa1 and TR-(3 (Marsh et al 1998), although the latter binding is with low affinity. 
During the competitive binding of the selected chemical fractions was observable that the fractions containing the hydroxylated congeners of PCBs and PBDEs had the higher affinity, with differences among human and gull TH transport proteins. Where humans TTR was disrupted greatly towards binding $T_{4}$, while gull were more affected in albumin binding $T_{3}$, not surpringly since had been demonstrated the natural affinity of bird albumin for T3 and human TTR for $T_{4}$ (Ucan et al, 2009a)

\subsubsection{Comparison of contaminants}

ZPCB, ZOH-PCB, £PBDE, £OH-PBDE, £MeO-PBDE, £CHL, £CBz, £ D D T a nd XMirex had potential associations between the concentrations of POPs and tissues/sites contained in the interaction area and concentrations (Figure 19 and 20). A positive relation of plasma from Hamilton Harbour and the livers of herring gulls from Scotch Bonnet Island were found (Figure 19). Also a direct relation between plasma $\mathrm{HH}$ and liver SB, and negative with Liver $\mathrm{HH}$ and Plasma SB was observed (Figure 20). £OH-PCB and $\mathrm{XOH}-\mathrm{BDE}$ containgin fractions had the closer association with plasma, then liver, than £PBDE, £CBz, $\mathrm{XCHL}$, £DDT, XMeO-PBDE and £Mirex. The relation observed in this study between OH-PCBs and PBDEs, suggest that not all OH-PCBs are excreted; several circulate in blood (Park et al 2007) and may exert toxicological effects, particularly on the thyroid system. OH-PCBs compete with and replace T4 on TTR, a possible indication of endocrine disruption associated with hypothyroidism (Lans et al 1993; Meerts et al 2002; Ucan Marin et al 2009a). 


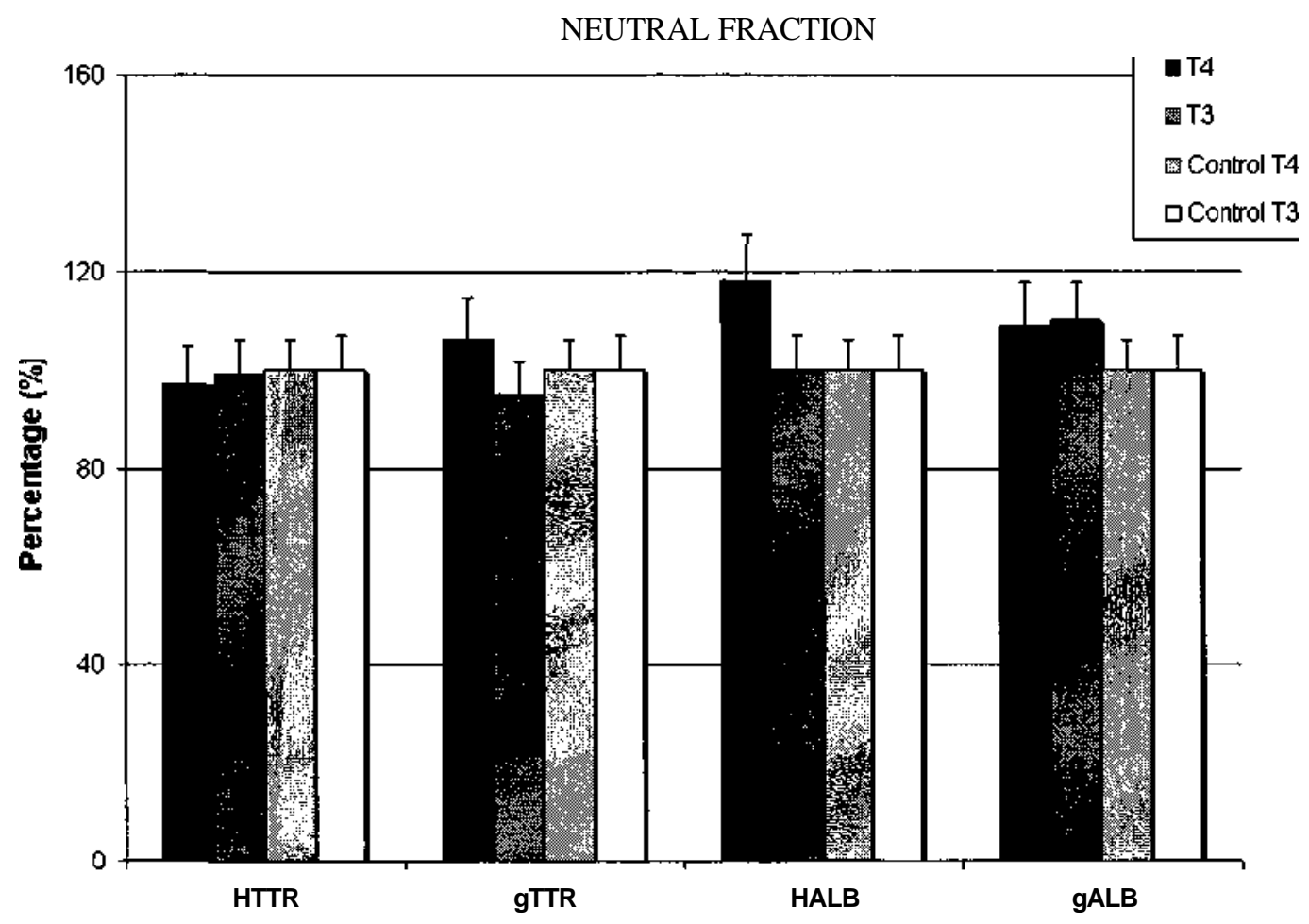

Figure 17. Extracted fraction-dependent, competitive binding assay for recombinant gull albumin (gALB) and transthyretin (gTTR), and recombinant human hALB and hTTR, with T3 or T4 in presence of Neutral Fraction (SE \pm ). Percentage of competitive binding is based in control ${ }^{125} \mathrm{I}-\mathrm{T} 4$ and ${ }^{125} \mathrm{I}-\mathrm{T}_{3}$. 


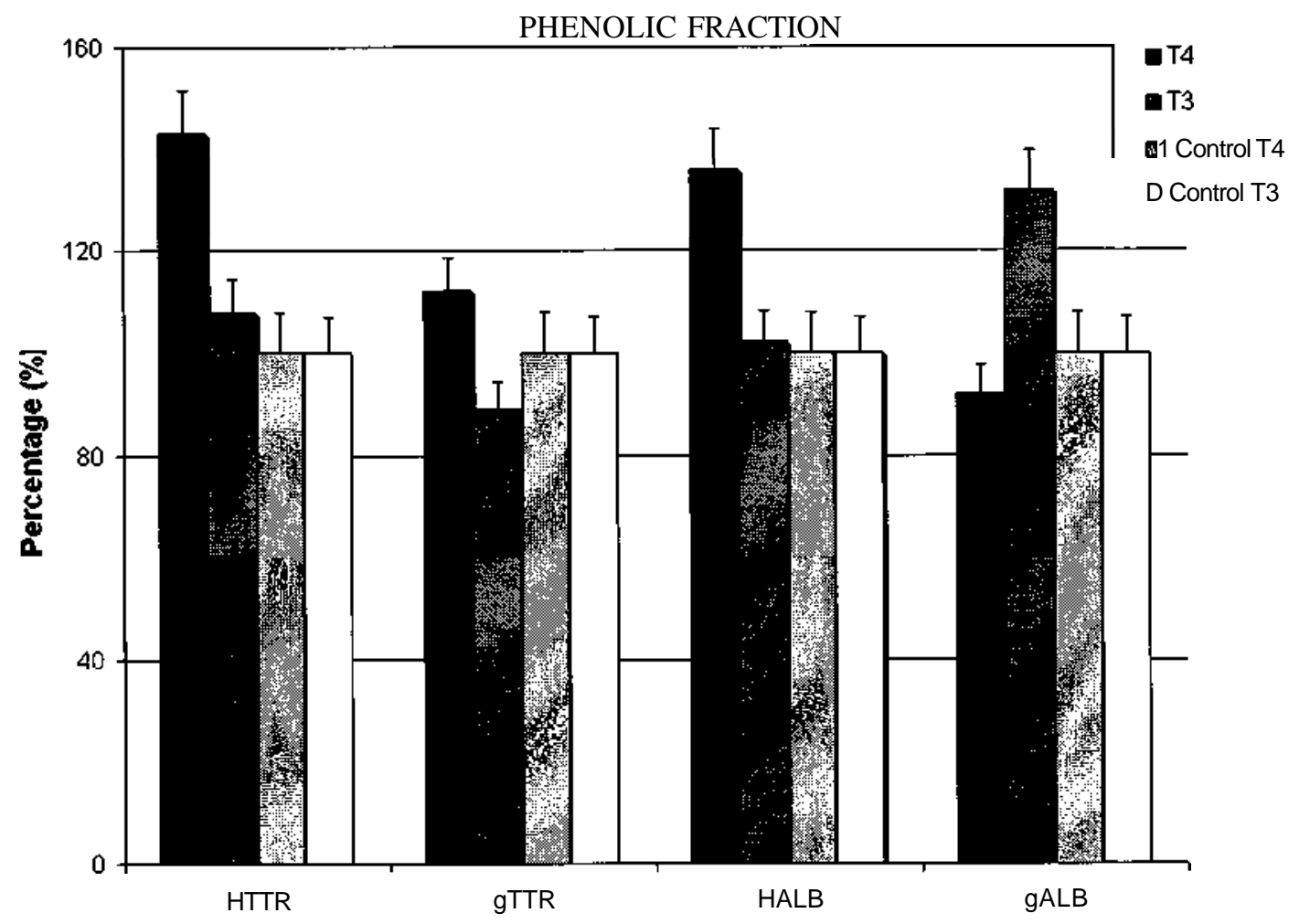

Figure 18. Extracted fraction-dependent, competitive binding assay for recombinant gull albumin (gALB) and transthyretin (gTTR), and recombinant human hALB and hTTR, with T3 or T4 in presence of Phenolic fraction (SE \pm ). Percentage of competitive binding is based in control ${ }^{125}$ |-T4 and ${ }^{125}$ I-T3- 
Recent evidence suggests that some of the hydroxylated metabolites of PCBs (OH-PCBs) may be more toxic than their parent compounds. These metabolites are formed in vivo by cytochrome P450 enzymes which oxidize PCBs to more water-soluble forms (e.g., OH-PCBs) via a 1,2 shift (NIH shift) or direct oxygen insertion (Letcher et al 2000).

Association were observed for selected major PCB and PBDE compounds with phenyl group substituents (i.e., $\mathrm{OH}$ ) that modify physicochemical characteristic such as polarity, with circulating plasma. Substances typically shown as having lipophilic properties such as PCBs and CHLs, had negative values but a correlative association with livers of herring gulls from Hamilton Harbour. These data suggests that exist a tissue-specific relation and this play an important role, together with numerous other biochemical processes, in the toxicokinetics and fate of chlorinated and brominated contaminants (and metabolic) and natural products. Further studies are necessary to investigate the mechanisms of macromolecule selection and binding interactions with hydroxylated organohalogen accumulation in avian species.

TH binding to Human recombinant albumin showed significant differences ( $p>0.003$ ) when compared to control $T 4$, and $T_{3}$ did not show any difference. Human albumin in presence of the phenolic fraction extraction was disrupted significantly compared to $\mathrm{T} 3$, but recombinant albumin from gulls did not have 
differences. For the gull albumin, the presence of the phenolic fraction and $T_{4}$ had a small decrease of $8 \%$ in the binding of $\mathrm{T}_{4}$; and $\mathrm{T} 3$ had $32 \%$ higher binding than control. Meaning that albumin cloned from gulls in presence of the phenolic mixture extraction was significantly disturbed by more than $30 \% \quad(p<0.001)$; concluding the higher sensitivity of $T_{3}$ to the phenolic fraction compared to $T 4$ in herring gulls.

In the phenolic fraction used in this assay, I include compounds such as $\mathrm{OH}$ PCBs which are known to be driven by the biotransformation of PCBs in the body, external sources such as fish intake and the abiotic environment possibly contribute to the body burden of OH-PCB metabolites (Campbell et al 2003; Hasegawa et al 2007; Ueno et al 2007). Due to their chemical structure that involves a hydroxyl group in either the para- or meta-position of a biphenyl ring, adjacent to chlorine atoms on both sides (Lans et al 1993; Letcher et al 2000, Ucan Marin et al 2009a, 2009b) is a suitable compound to bind to TH transport proteins TTR and albumin. The phenolic fraction isolated in this study contain the most dominant $\mathrm{OH}-\mathrm{PCB}$ congeners, 4-OH-CB187, that was found in the present study, and has been considered as a biologically active compound (Meerts et al 2002; Negishi et al, 2007; Otake et al 2007; Park et al 2009). This is the first report on circulating £OH-PCB, ZOH-PBDE, £PBDE and £MeO-PBDEs in herring gulls from the Laurentian Great Lakes. 
$1.5-1$

\section{H}

\section{KH Plasma HH}

0.5

if UverSB

$1 \quad$ UverHH

$\cdot 0.5$

W Plasma SB

$\cdot 1.5^{\mathrm{J}}$

Figure 19. Proportions of the four tissues compared and their colony location plotted using the two first principal components (PCs), PC 1 and PC 2. Mean ( \pm 1 standard error) factor scores (right biplot) are showed for Hamilton Harbour and Scotch Bonnet Island. 


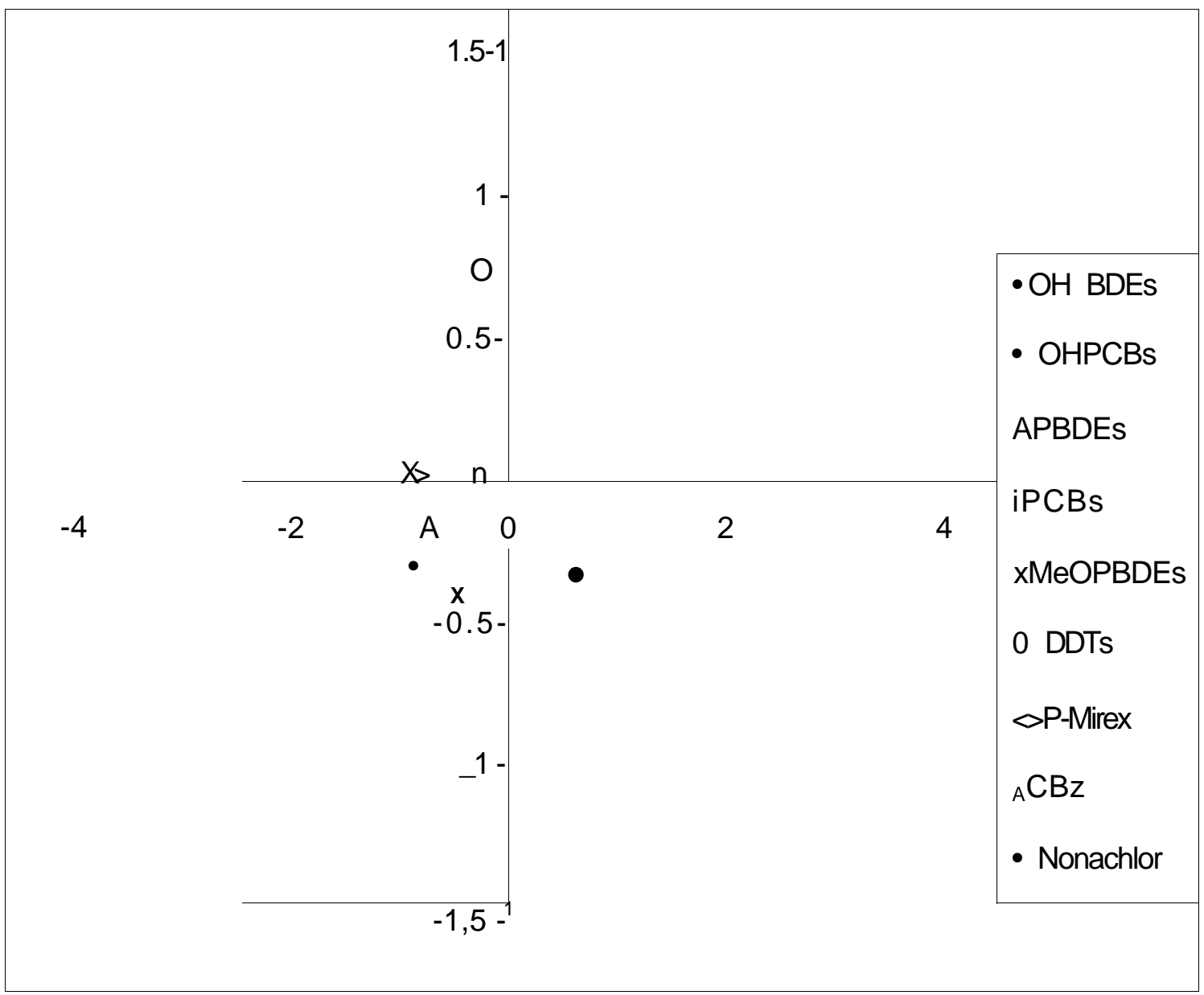

Figure 20. Proportions of nine major chlorinated and brominated contaminant classes or individual compounds plotted using the two first principal components (PCs), PC 1 and PC 2. Mean ( \pm 1 standard error) factor scores (right biplot) are showed. 
With the results and data obtained in the competitive binding assays with phenolic and neutral fractions, was observable that concentrations of $\mathrm{OH}$ $\mathrm{PCB} / \mathrm{PBDE}$ found in the chemical phenolic fraction were able to affect normal $\mathrm{TH}$ binding (compared to control). Even, it has been demonstrated that some $\mathrm{OH}$ PCBs (Purkey et al 2004, Ucan Marin et al 2009a) and OH-PBDEs (Meerts et al., 2000, Ucan Marin et al 2009a), are able to disrupt thyroid hormone binding. With these results, it was confirmed that hydroxylated contaminants contained in a complex chemical fractions were able to disrupt competitive binding of THs with $\mathrm{TH}$ transport proteins, as if they were tested individually. In this study it was confirm that the differences among human and avian TTR and albumin in presence of exogenous complex mixtures are significant and important.

The development and validation of complex mixtures through in vitro assays, is reliable and relevant to in vivo exposures, will provide an attractive and economical alternative to the in vivo assays for regulatory purposes. It will provide an opportunity for some studies in species (such as humans, marine mammals and diverse endangered species) for which controlled in-vivo exposures would be impractical for logistic, economic as well as ethical reasons. Another significant outcome for preliminary complex mixture screening is the opportunity to address some clarification of the interactions (agonistic/antagonistic properties) of individual compounds in immunotoxicity of mixtures of OCs. This will provide directions and help define research hypothesis 
for further mechanistic studies. The expected results should also shed some light on the difference of susceptibility of different species of birds to the immunotoxic effects of mixtures of OCs. This could be a useful tool for wildlife conservation as well as population and habitat management. Finally, a better understanding of avian immunotoxicology and physiological response (using thyroid system model) may provide a good model for predicting the risk associated with life-long exposure to low concentrations of environmental contaminants in complex mixtures, such as experienced by human beings.

\subsubsection{Conclusions}

Polychlorinated biphenyls (PCBs) concentrations levels in plasma found in this study were lower compared with historical data reported for the Great Lakes. This study contributes with novel concentration data from two colonies of herring gulls from the Lake Ontario (Hamilton Harbour and Scotch Bonnet Island). It appears that polybrominated diphenyl ethers (PBDEs) trend follow the historical increase of the concentrations levels previously reported for the Great Lakes. This study also contributes with the first report of hydroxylated-PCBs/PBDEs $(\mathrm{OH}-\mathrm{PCBs}$ and $\mathrm{OH}$ PBDEs), and Methoxylated brominated diphenyl ethers (XMeO-PBDEs) in plasma and liver of Herring gulls at Lake Ontario (and any avian in the Great Lakes). Differences were also observed in the affinity of $\mathrm{TH}$ transport proteins between humans and herring gulls (and between fractions), where the phenolic chemical complex fractions had higher affinity, and consequently higher capacity to disrupt TH binding from TTR and albumin. 


\subsection{References}

Alcock RE, Boumphrey R, Malcolm HM, Osborn D, Jones KC, 2002. Temporal and spatial trends of PCB congeners in UK gannets. Ambio 31:202-206.

Baker JE, 1997. Atmospheric Deposition of Contaminants to the Great Lakes and Coastal Waters. , SETAC (Society) Meeting (15th: 1994 : Denver SETAC Press, Pensacola, Florida).

Barrett RT, Skaare JU, Gabrielsen GW, 1996. Recent changes in levels of persistent organochlorines and mercury in eggs of seabirds from the Barents Sea. Environmental Pollution 92: 13-18.

Becker PH, Munoz Cifuentes J, Behrends B, Schmieder KR, 2001. Contaminants in bird eggs in the Wadden Sea. Spatial and temporal trends 1991-2000. Wadden Sea Ecosystem No. 11. Common Wadden Sea Secretariat, Trilateral Monitoring and Assessment Group, Wilhelmshaven, Germany.

Bern $\mathrm{H}$ et al. 1992. Statement from the work session on chemically-induced alterations in sexual development: the wildlife/human connection, pp 1-8 in Chemically-Induced Alterations in Sexual and Functional Development: The Wildlife/Human Connection, eds T Colborn and C Clement, Princeton Scientific Publishing Co., NJ, U.S

Bignert B, Olsson B, Persson W, Jensen S, Zakrisson S, Litzen K, et al, 1998. Temporal trends of organochlorines in Northern Europe, 1967-1995. Relation to global fractionation, leakage from sediments and international measures, Environ Pollut 99: 177-198.

Braune BM, Outridge PM, Fisk AT, Muir DCG, Helm PA, Hobbs K, Hoekstra PF, Kuzyk ZA, Kwan M, Letcher RJ, Lockhart WL, Norstrom RJ, Stern GA, Stirling I, 2005. Persistent organic pollutants and mercury in marine biota of the Canadian Arctic: an overview of spatial and temporal trends. The Sci of the Tot Environ 351/352: 4-56.

Brouwer A, Reijnders PJH, Koeman JH, 1989. Polychlorinated biphenyl (PCB)contaminated fish induces vitamin $A$ and thyroid hormone deficiency in the common seal (Phoca vitulina). Aquat Toxicol 15: 99-106.

Campbell LM, Muir DCG, Whittle DM, Backus S, Norstrom RJ, Fisk AT, 2003. Hydroxylated PCBs and other chlorinated phenolic compounds in lake trout (Salvelinus namaycush) blood plasma from the Great Lakes Region. Environ Sci Tech 37: 1720-1725 
Chen D, Zhang X, Mai B, Sun Q, Son J, Luo X, Zeng E, Hale R, 2009. Polychlorinated biphenyls and organochlorine pesticides in various bird species from northern China. Environmental Pollution 157: 2023-2029.

Chu S, Covaci A, Jacobs W, Haraguchi K, Schepens P, 2003. Distribution of methyl sulfone metabolites and polychlorinated biphenyls and p, p'-DDE in human tissues. Environ Health Perspec 111: 1222-1227.

Colborn T, Clement CR, eds. 1992. Chemically Induced Alterations in Sexual and Functional Development: The Wildlife/Human Connection. Princeton, NJ: Princeton Scientific Publishing, 430 pp.

Colborn T, 2002. Clues from Wildlife to Create an Assay for Thyroid System Disruption. Environmental Health Perspectives 110(3): 363-367.

de Wit CA, 2002. An overview of brominated flame retardants in the environment, Chemosphere 46: 583-624.

Darnerud PO, 2003. Toxic effects of brominated flame retardants in man and in wildlife, Environment International 29: 841-851.

Dietz R, Riget F, Hobson KA, Heide-Jorgensen MP, MOller P, Cleemann M, de Boer J, Glasius M, 2004.Regional and inter annual patterns of heavy metals, organochlorines and stable isotopes in narwhals (Monodon monoceros) from West Greenland. Science of the Total Environment, Volume 331(1-3): 83-105.

Eisenreich SJ, 1981. Atmospheric Pollutants in Natural Waters, Ann Arbor Science Publishers Inc, Ann Arbor, Michigan, 512 p.

Ewins PJ, Weseloh DV, Mineau P. 1992. Geographical distribution of contaminants and productivity measures of herring gulls in the Great Lakes: Lake Huron 1980. J Great Lakes Res. 18:316-330.

Environment Canada, 2009. Contaminants in Herring Gull Eggs from the Great Lakes: 25 Years of Monitoring Levels and Effects (Environment Canada). Great Lakes Fact Sheet, www.on.ec.gc.ca/wildlife/factsheets/fs herring gulls-e.html (accessed on Oct 1, 2009).

Fox GA, Gilberston M, Gilman AP, Kubiak TJ, 1991a. A rationale for the use of colonial fish-eating birds to monitor the presence of developmental toxicants in Great Lakes fish. J. Great Lakes Res 17:151-152.

Fox GA, Waseloh DV, Kubiak TJ, Erdman TC. 1991b. Reproductive outcomes in colonial fish-eating birds: a biomarker for developmental toxicants in Great Lakes food chains. I. Historical and ecotoxicological perspectives. J. Great Lakes Res 17: 153-157. 
Fox, GA. 1993. What have biomarkers told us about the effects of contaminants on the health of fish-eating birds in the Great Lakes? The theory and a literature review. Journal of Great Lakes Research 19(4):722-736.

Fry DM, Toone CK, 1981, DDT-induced feminisation of gull embryos, Science 213: $922-924$.

Gauthier LT, Hebert CE, Weseloh DVC, Letcher RJ, 2008. Dramatic changes in the temporal trends of polybrominated diphenyl ethers (PBDEs) in herring gull eggs from the Laurentian Great Lakes: 1982-2006. Environ Sci Technol 42(5): 1524-30.

Gauthier LT, Potter D, Hebert CE, Letcher RJ, 2009. Temporal trends and spatial distribution of non-polybrominated diphenyl ether flame retardants in the eggs of colonial populations of Great Lakes herring gulls. Environ Sci Technol 43(2): 3127.

Gebbink WA, Sonne C, Dietz R, Kirkegaard M, Riget FF, Born EW, Muir DCG, Letcher RJ. 2008a. Tissue-specific congener composition of organohalogen and metabolite contaminants in East Greenland polar bears (Ursus maritimus), Environ Poll 152: 621-629.

Gebbink WA, Sonne C, Dietz R, Kirkegaard M, Born EW, Muir DCG, Letcher RJ. 2008b. Target tissue selectivity and burdens of diverse classes of brominated and chlorinated contaminants in polar bears (Ursus maritimus) from East Greenland. Environ Science and Technol 42: 752-759.

Grasman KA, Fox GA, Scanlon PF, Ludwig JP, 1996. Organochlorine-associated immunosuppression in prefledgling Caspian terns and herring gulls from the Great Lakes: an ecoepidemiological study. Environmental Health Perspectives 104(4): 829-842.

Gilbertson M, 1974a. Seasonal changes in organochlorine compounds and mercury in Common Terns of Hamilton Harbour, Ontario. Bull. Environ Contam Toxicol 12: 726-32.

Gilman AP, Fox GA, Peakall DB, Teeple SM, Carroll TR, Haymes GT, 1977. Reproductive parameters and egg contaminant levels of Great Lakes Herring Gulls. J Wildl. Manage 41:458-68.

Guillette LJ Jr, Crain DA, Gunderson MP, Kools SAE, Milnes MR, Orlando EF, Rooney AA, Woodward AR, 2000. Alligators and endocrine disrupting contaminants: a current

perspective. Am Zool 40: 438-452. 
Haffner GD, Straughan CA, Weseloh DV, Lazar R, 1997. Leveies of Polychorinated Biphenyls, including coplanar congeners, and 2,3,7,8-T4 CDD toxic equivalents in double-crest Cromorant and Herring gull eggs from Lake Erie and Lake Ontario: A comparison between 1981 and 1992. J Great Lakes Res 23(1): 52-60.

Hair JF, Anderson RE, Tatham RL, Black WC, 1998. Multivariate data analysis. 5th ed. New-Jersey, USA: Prentice Hall 87-138.

Hakk $H$, Letcher RJ, 2003. Metabolism in the toxicokinetics and fate of brominated flame-retardants - a review. Environ Internat 29: 801-828.

Halldin K, Holm L, Ridderstrale Y, Brunstrom B, 2003. Reproductive impairment in Japanese quail (Coturnix japonica) after in ovo exposure to o,p'-DDT. Arch. Toxicol. 77: 116-122

Harris ML, Wilson LK, Elliott JE, 2005. An assessment of PCBs and OC pesticides in eggs of double-crested (Phalacrocorax auritus) and pelagic ( $P$. pelagicus) cormorants from the west coast of Canada, 1970 to 2002. Ecotoxicology 14: 607-625.

Hasegawa J, Matsuda M, Ohnishi $\mathrm{H}$, Enomoto $\mathrm{T}$, Kwawano $\mathrm{M}$, Wakimoto $\mathrm{T}$, 2007. PCBs and hydroxylated PCB metabolites in the tissues of wild birds and fish prey from Japan, Organohalog Compd 69: 1495-1498.

Herbert CE, Norstrom RJ, Simon M, Braune BM, Waseloh DV, MacDonnald CR, 1994. Temporal trends and sources of PCDDs and PCDFs in the Great Lakes: herring gull egg monitoring, 1981-1991. Environ Sci Technol 28: 1268-1277.

Hebert CE, Shutt JL, Hobson KA, Weseloh DV, 1999. Spatial and temporal differences in the diet of Great Lakes herring gulls (Larus argentatus): evidence from stable isotope analysis. Can J Fish Aquat Sci 56(2): 323-338.

Jaspers VLB, Covaci A, Voorspoels S, Dauwe T, Eens M, Schepens P, 2006. Brominated flame retardants and organochlorine pollutants in aquatic and terrestrial predatory birds of Belgium: levels, patterns, tissue distribution and condition factors. Environmental Pollution, 139(2): 340-352.

Jobling S, Nolan M, Tyler CR, Brighty G, Sumpter JP, 1998. Widespread sexual disruption in wild fish. Environ Sci Technol 32(17): 2498-2506.

Lans MC, Klasson-Wehler E, Willemsen M, Meussen E, Safe S, Brouwer A, et al. 1993. Structure- dependent, competitive interaction of hydroxypolychlorobiphenyls, -dibenzo-p-dioxins and dibenzofurans with human transthyretin. Chem-Biol Interact 88: 7-21. 
Legler J, Brouwer A, 2003. Are brominated flame retardants endocrine disruptors? Environment International 29: 879-885.

Levin M, Morsey B, Mori C, Nambiar PR, De Guise S, 2005. PCBs and TCDD, alone and in mixtures, modulate marine mammal but not B6C3F1 mouse leukocyte phagocytosis. Journal of Toxicology and Environmental Health-Part $A$ 68(8): 635-656.

Levin M, Morsey B, De Guise S. Modulation of the respiratory burst by organochlorine mixtures in marine mammals, humans and mice. Journal of Toxicology and Environmental Health-Part A 70(1): 73-83.

Lindberg, P., Sellstrom, U., Haggberg, L., and de Wit, C. A. (2004). Higher brominated diphenyl ethers and hexabromocyclododecane found in eggs of peregrine falcons (Falco peregrinus) breeding in Sweden. Environ. Sci. Technol. 38, 93-96.

Malberg T, Athanasiadou M, Marsh G, Brandt I, Bergman A, 2005. Identification of hydroxylated polybrominated diphenyl ether metabolites in blood plasma from polybrominated diphenyl ether exposed rats Environmental science \& technology 39(14): 5342-5348.

Mallory Mark L; Braune Birgit M; Wayland Mark; Drouillard Ken G. 2005. Persistent organic pollutants in marine birds, arctic hare and ringed seals near Qikiqtarjuaq, Nunavut, Canada. Marine pollution bulletin 2005;50(1):95-101.

Marsh G, Bergman A, Bladh LG, Gillner M, Jakobsson E, 1998. Synthesis of $p$ hydroxybromodiphenyl ethers and binding to the thyroid receptor. Organohalogen Compounds 37: 305-308.

McKinney MA, De Guise S, Martineau D, Beland P, Lebeuf M, Letcher RJ. 2006. Organohalogen contaminants and metabolites in beluga whale (Delphinapterus leucas) liver from two Canadian populations. Environ Toxi and Chem 25: 30-41.

McNabb FMA, RJR McCleary, LA Fowler, CM Parsons, KA Grasman, Fox GA. 2001. Thyroid function in PCB-exposed avian embryos and chicks. In Perspectives in Comparative Endocrinology: Unity and Diversity (JJTh Goos, RK Rastogi, H Vaudry and R Pierantoni, eds.). Bologna, Italy: Monduzzi Editore, pp. 275-280.

Meerts IATM, van Zanden JJ, Luijks EAC, van Leeuwen-Bol I, Marsh G, Jakobsson E, Bergman A, Brouwer A, 2000. Potent Competitive Interactions of Some Brominated Flame Retardants and Related Compounds with Human Transthyretin in Vitro. Toxicological Sciences 56: 95-104. 
Meerts IATM, Assink Y, Cenijn PH, van den Berg JHJ, Weijers VM, Bergman A, etal., Placental transfer of a hydroxylated polychlorinated biphenyl and effects on fetal and maternal thyroid hormone homeostasis in the rat. Toxicol Sci 68: 361371.

Mineau P, Fox GA, Norstrom RJ, Weseloh DV, Hallett DJ, Ellenton JA, 1984. Using the herring gull to monitor levels and effects of organochlorine contamination in the Canadian Great Lakes. In Toxic Contaminants in the Great Lakes (JD Nriagu, MS Simmons, eds.). New York: John Wiley \& Sons, pp. 425452.

Moccia RD, Fox GA, Britton A, 1986. A quantitative assessment of thyroid histopathology of herring gulls (Larus argentatus) from the Great Lakes and a hypothesis on the causal role of environmental contaminants. Journal of Wildlife Diseases 22(1): 60-70.

Montie EW, Reddy CM, Gebbink WA, Touhey KE, Hahn ME, Letcher RJ, 2009. Organohalogen contaminants and metabolites in cerebrospinal fluid and cerebellum gray matter in short-beaked common dolphins and Atlantic whitesided dolphins from the western North Atlantic. Environ Poll 157(8-9): 2345-2358.

Muir DCG, Backus SM, Derocher AE, Dietz R, Evans T, Gabrielsen GW, Nagy J, Norstrom RJ, Sonne C, Stirling I, Taylor MK, Letcher RJ, 2006. Brominated flame retardants in polar bears (Ursus maritimus) from Alaska, the Canadian Arctic, Greenland, and Svalbard. Environ Sci and Tech 40: 449-455.

Negishi T, Takahashi M, Tashiro T, 2007. Alterations in gene expression by exposure to hydroxylated polychlorinated biphenyls in developing rat brain. Organohalog Compd 69: 424-427.

Noren K, Meironyte D, 2000. Certain organochlorine and organobromine contaminants in Swedish human milk in perspective of past 20-30 years. Chemosphere 40: 1111-1123.

Norstrom RJ, Clark TP, MacDonnald CR, 1991. The herring gull bioenergetics and pharmacodynamics model compiled spreadsheet ver 1.0. Hull. Quebec: Canadian Wildlife Service.

Norstrom RJ, Simon M, Moisey J, Wakeford B, Weseloh DVC, 2002. Geographical distribution (2000) and temporal trends (1981-2000) in brominated diphenyl ethers in Great Lakes herring gull eggs, Environmental Science and Technology 36: 4783-4789.

Lans M.C., Klassonwehler E, Willemsen M, Meussen E, Safe S, Brouwer A, 1993. Structure-Dependent, competitive interaction of hydroxy- 
polychlorobiphenyls, hydroxy-dibenzo-p-dioxins and hydroxy-dibenzofurans with human transthyretin. Chem-Biol Interact 88: 7-21.

Letcher RJ, Klasson-Wehler E, Bergman A, 2000. Methyl sulfone and hydroxylated metabolites of polychlorinated biphenyls. In: The Handbook of Environmental Chemistry, Vol 3, Part K: New Types of Persistent Halogenated Compounds (Paasivirta J, ed). Berlin:Springer-Verlag, 315-359.

Lipson SM, 1987. Effect of polybrominated biphenyls on the growth and maturation of human peripheral blood lymphocytes, Clinical Immunology and Immunopathology $43 \mathrm{pp}$.

Olafsdottir K, Petersen /E, Magnusdottir EV, Bjornsson T, Johannesson T, 2005. Temporal trends of organochlorine contamination in black guillemots in Iceland from 1976 to 1996. Environmental Pollution 133: 509-515.

Otake T, Yoshinaga J, Enomoto T, Matsuda M, Wakimoto T, Ikegami M, ef a/, 2007. Thyroid hormone status of newborns in relation to in utero exposure to PCBs and hydroxylated PCB metabolites. Environ Res 105: 240-246.

ParkJS, Linderholm L, Charles MJ, Athanasiadou M, Petrik J, Kocan A, ef a/, Polychlorinated biphenyls and their hydroxylated metabolites (OH-PCBs) in pregnant women from eastern Slovakia. Environ Health Perspect 115: 20-27.

Park HY, Sovcikova JS, Kocan E, Trnovec A, Linderholm T, et al, 2009. Exposure to hydroxylated polychlorinated biphenyls (OH-PCBs) in the prenatal period and subsequent neurodevelopment in eastern Slovakia. Environ Health Perspect 117: 1600-1606.

Powell DC, Aulerich RJ, Meadows JC, Tillitt DE, Giesy JP, Stromborg KL, Bursian SJ, 1996. Effects of 3,3.,4,4.,5-pentachlorobiphenyl (PCB 126) and 2,3,7,8-tetrachlorodibenzo-p-dioxin (TCDD) injected into the yolks of chicken (Gallus domesticus) eggs prior to incubation. Archives of Environmental Contamination and Toxicology 31: 404-409.

Purkey HE, Palaninathan SK, Kent KC, Smith C, Safe SH, Sacchettini JC, Kelly JW, 2004. Hydroxylated polychlorinated biphenyls selectively bind transthyretin in blood and inhibit amyloidogenesis: rationalizing rodent PCB toxicity. Chem and Biol 11: 1719-1728.

Reijnders PJH, Brasseur SMJM, 1992. Xenobiotic induced hormonal and associated developmental disorders in marine organisms and related effects in humans; an

overview. In: Chemically Induced Alterations in Sexual and Functional Development: The Wildlife/Human Connection (Colborn T, Clement C, eds). Princeton, 
NJ:Princeton Scientific Publishing, 159-174 pp.

Sandala GM, Sonne-Hansen C, Dietz R, Muir DCG, Valters K, Bennett ER, Born $\mathrm{EW}$, Letcher RJ, 2004. Hydroxylated and methyl sulfone PCB metabolites in adipose and whole blood of polar bear (Ursus maritimus) from East Greenland. Science of the Total Environment 331: 125-141.

Schantz SL, Moshtaghian J, Ness DK, 1995. Spatial Learning Deficits in Adult Rats Exposed to ortho-Substituted PCB Congeners during Gestation and Lactation Fundamental and Applied Toxicology. 26(1): 117-126.

Sellstrom, U., Bignert, A., Kierkegaard, A., Haggberg, L., de Wit, C. A., Olsson, M., and Jansson, B, 2003. Temporal trend studies on tetra- and pentabrominated diphenyl ethers and hexabromocyclodedecane in Guillemot egg from the Baltic Sea. Environ. Sci. Technol. 37, 5496-5501.

Stapleton H, Keller J, Schantz M, Kucklick, J, Leigh S, Wise S, 2007. Determination of polybrominated diphenyl ethers in environmental standard reference materials. Analytical and Bioanalytical Chemistry, 387(7): 2365-2379.

Stapleton HM, Kelly SM, Pei R, Letcher RJ, Gunsch C, 2009. Metabolism of polybrominated diphenyl ethers (PBDEs) by human hepatocytes in vitro. Environmental health perspectives 117(2): 197-202.

StatSoft. 2004. STATISTICA, Ver 6.1.409.0. Tulsa, OK, USA.

Ter Braak CJF, Smilauer P, 1998. CANOCO Reference Manual and Users Guide to CANOCO for Windows: Software for CANOCO Community Ordination, Version 4. Microcomputer Power, Ithaca, NY, USA.

Thyen S, Becker PH, Behmann H, 2000. Organochlorine and mercury contamination of little terns (Sterna albifrons) breeding at the western Baltic Sea, 1978-96. Environmental Pollution 108: 225-238.

Ucan-Marin F, Arukwe A, Mortensen A, Gabrielsen DW, Fox GA, Letcher RJ, Recombinant transthyretin purification and competitive binding with organohalogen compounds in two gull species (Larus argentatus and Larus hyperboreus). Toxicological Sciences 107(2): 440-450.

Ucan-Marin F, Arukwe A, Mortensen AS, Gabrielsen GW, Letcher RJ. 2009b. Recombinant albumin and transthyretin transport proteins from two gull species and human: Chlorinated and brominated contaminant binding and thyroid hormones Environmental Science \& Technology accepted.

Ueno D, Darling C, Alaee M, Campbell L, Pacepavicius G, Teixeira C, et al, 2007. Detection of hydroxylated polychlorinated biphenyls (OH-PCBs) in the 
abiotic environment: surface water and precipitation from Ontario, Canada. Environ Sci Technol 41: 1841-1848.

Vander Pol SS, Becker PR, Kucklick JR, Pugh RS, Roseneau DG, Simac KS, 2004. Persistent organic pollutants in Alaskan murre (Uria spp.) eggs: geographical, species, and temporal trends. Environmental Science and Technology 38: 1305-1312.

Verboven N, Verreault J, Letcher RJ, Gabrielsen GW, Evans NP, 2009. Nest temperature and parental behaviour of Arctic-breeding glaucous gulls exposed to persistent organic pollutants. Animal Behaviour 77(2): 411-418

Verreault, J, Gabrielsen, GW, Chu SG, Muir DCG, Andersen M, Hamaed A, Letcher RJ, 2005. Flame retardants and methoxylated and hydroxylated polybrominated diphenyl ethers in two Norwegian Arctic top predators: Glaucous gulls and polar bears. Environ Sci Technol 39: 6021-6028.

Verreault J, Shahmiri S, Gabrielsen GW, Letcher RJ, 2007. Organohalogen and metabolically-derived contaminants and associations with whole body constituents in Norwegian Arctic glaucous gulls. Environment International 33(6): 823-830.

Waring $\mathrm{RH}$, Harris RM, 2005. Endocrine disrupters: A human risk? Molecular and Cellular Endocrinology 244(1-2)1: 2-9.

Weseloh DV, Mineau P, Hallett DJ, 1979. Organochlorine contaminants and trends in reproduction in Great Lakes Herring Gulls 1974-1978. Trans North Amer Wildl and Nat Resources Conf 44: 543-57.

Weseloh DV, Custer TW, Braune BM, 1989. Organochlorine Contaminants in Eggs of Common Terns from the Canadian Great Lakes, 1981. Environmental Pollution 59: 141-160.

Waseloh DV, Mineau P, Struger J, 1990. Geographical distribution of contaminants and productivity measures of herring gulls in the Great Lakes: Lake Erie and connecting channels 1978/79. The Science of the Total Environment 91: 141-159.

Waseloh DV, Ewins PJ, Struger J, Mineau P, Norstrom RJ, 1994. Geographical distribution of organochlorine contaminants and reproductive parameters in herring gulls in Lake Superior in 1983. Environmental Monitoring and Assessment 29: 229-251.

Weseloh DV, Hamr P, Bishop CA, Norstrom RJ, 1995. Organochlorine Contaminant Levels in Waterbird Species from Hamilton Harbour, Lake Ontario: an IJC Area of Concern. Journal of Great Lakes Research. 21(1): 121-137. 
Weihe P, Hoppe HW, Grandjean P, 2003. Sustained high concentrations of PCBs in Faroese pregnant women despite dietary intervention Organohalogen Cmpds 63: 389-392. 
CHAPTER SIX ${ }^{4}$

\section{Perfluoroalkyl Compounds (PFCs) and PFC-Containing Complex Mixtures \\ Isolated From Herring Gull Liver (Lake Ontario): Comparative In Vitro \\ Competitive Binding With Thyroid Hormones on Gull and Human Albumin \\ and Transthyretin Transport Proteins}

\subsection{Abstract}

Herring gulls (Larus argentatus) from the Great Lakes are top avian predators in the aquatic food web, but have also been shown to have a terrestrial component to their diet. There is a dearth of information, especially for wild avian species, on the PFC-mediated perturbation of thyroid hormone (TH)-dependent processes; particularly on $\mathrm{TH}$ transport. Cloned, expressed and purified herring gull recombinant transthyretin (rTTR) and albumin (rALB) and commercially available human TTR and ALB were studied in a competitive binding assays (CBA) to assess the interactions between complex chemical fractions isolated from gull livers that inhabit in two colonies of Lake Ontario. The £PFSA chemical neutral fraction containing e.q perflurooctane sulafanomide (PFOSA) and the acidic

\footnotetext{
${ }^{4}$ This chapter is currently in preparation to be published as a paper in a peer-reviewed journal. "Ucan-Marin, et al, 2009. Perfluoroalkyl Compounds (PFCs) and PFC-Containing Complex Mixtures Isolated From Herring Gull Liver (Lake Ontario): Comparative In Vitro Competitive Binding With Thyroid Hormones on Gull and Human Albumin and Transthyretin Transport Proteins".
} 
fraction containing (PFBs, PHxS, PFOs, PFDA, PFUdA and PFTrDA) £PFCA. A representative compound from each complex mixture: FOSA and PFUdA were examined in competition with recTTR and recALB for 3,5,3'-triiodothyronine $\left(T_{3}\right)$ and thyroxine $\left(T_{4}\right)$. PFUnA was the dominant PFCA and PFOSA was also present in livers samples analyzed; and PFOS were the most abundant compound of the PFCs both colonies examined. CBA analysis show that relative to control in human and gull TTR, $\mathrm{T}_{4}$ and not T3 were displaced by PFUdA and the (acidic), PFCA- and PFSA-containing fractions. PFOSA was able to disrupt T4 binding of human TTR and the (neutral), PFOSA-containing fractions was able to disrupt T4 -human TTR binding; and $\mathrm{T}_{3}$ and $\mathrm{T} 4$ on human and gull albumin. Neutral and acidic PFCs chemical fractions differ in their affinity for $T_{3}$ and $T_{4}$, depending if were human/ gull and TTR/ALB. This study suggests a strong disruption possibility of $\mathrm{TH}$ transport proteins binding $\mathrm{THs}$ at environmentally relevant levels, caused hipotethicaly by the strong polar head of PFCs (mainly carboxylated) with a possible effect in $\mathrm{TH}$ homeostasis in freeranging gulls. 


\subsection{Introduction}

Perfluorinated compounds (PFCs) represent a large group of chemicals which are characterized by a fully fluorinated hydrophobic linear carbon chain attached to various hydrophilic heads. The chemical structures of some important PFCs are given in (Figure 21). PFCs have been produced since the 1950 s and are widely used for many industrial purposes and consumer-related applications (Prevedouros et al 2006). This is due to their unique physico-chemical characteristics such as chemical and thermal stability, low surface free energy and surface-active properties (Hekster et al 2003; Lehmler 2005).

In recent years, polyfluorinated chemicals (PFCs) have increasingly been used as surfactants in various industry- and consumer products, because of their unique properties as repellents of dirt, water and oils. The most well-known PFCs are perfluorooctane sulfonic acid (PFOS), perfluorooctanoic acid (PFOA) and their derivatives belonging to the group of perfluoroalkylated substances. The PFCs are very persistent in the environment, and some of them have been discovered as global pollutants of air, water, soil and wildlife and even found in remote polar areas (Ensen et al 2008). 


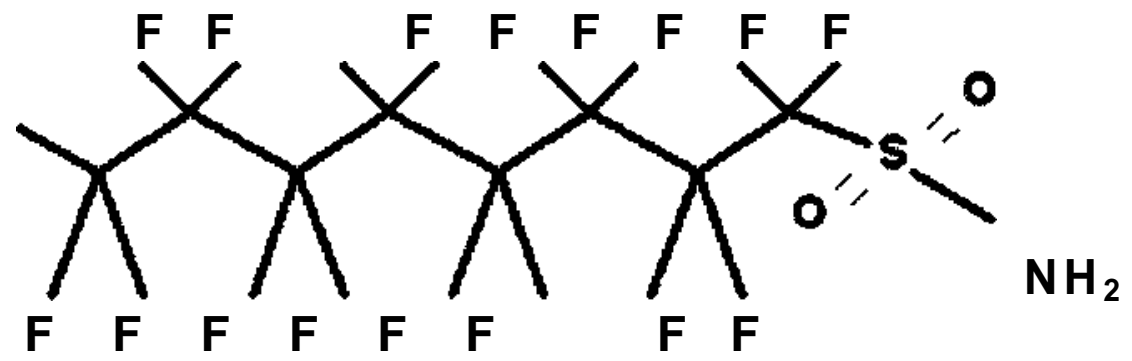

B

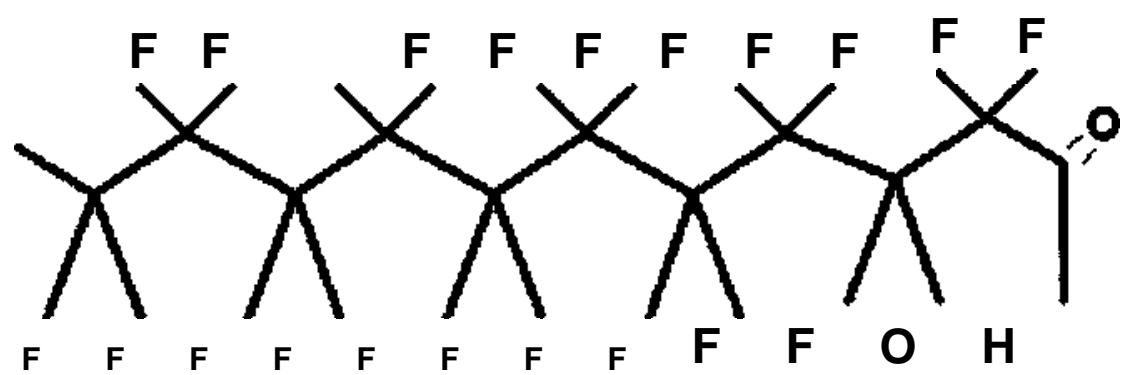

Figure 21. Chemical structure of two typical perfluorinated substances. (A) Perfluorooctane sulfonamide (PFOSA) $\mathrm{CF}_{3}(\mathrm{CF} 2) 7 \mathrm{S02} \mathrm{NH}_{2}$ Perfluoroundecanoic acid (PFUdA) $\mathrm{CF} 3\left(\mathrm{CF}_{2}\right) 9 \mathrm{CO}_{2} \mathrm{H}$. 
The C-F bond is particularly strong, and is resistant to various modes of degradation, including reaction with acids and bases, oxidation, and reduction (Kissa 2001). This resistance contributes to the extraordinary stability of PFCs. The most commonly studied PFC substances as environmental contaminants are the perfluorinated sulfonates and the perfluorinated carboxylates. Among these, PFOS and PFOA are of greatest concern; because both persist in humans and the environment (Fromme et al, 2009). PFOS, its precursors (e.g., PFOSA), and related compounds are used in many applications ranging from oil and water repellant coatings for carpets, textiles, leather, paper, cardboard, and food packing materials; electronic and photographic devices; and surfactants in diverse cleaning agents, cosmetics, and fire-fighting foams (OECD 2002; Kissa 2001). The more persistent PFCs, such as PFOS and PFOA, can also be formed in the environment from abiotic and biotic transformation of commercially synthesized precursors. PFOA, as its ammonium salt, is principally used as an essential processing aid in the manufacture of certain fluoropolymers such as polytetrafluoroethylene (PTFE) and to a lesser extent in industrial applications as an antistatic additive and in the electronic industry (OECD 2005).

During synthesis of PFCs via electrochemical fluorination (ECF) and subsequent commercial reactions, numerous substances such as perfluoroalkyl-sulfonamide alcohols were unintentionally produced, or remained as by-products in commercial products. Degradation of these substances has been observed in the 
ecosystem and in living organisms to produce persistent PFCAs or PFOS. For example, it has been demonstrated that perfluorooctane sulfonamides (PFOSA) can be metabolized to PFOS (Xu et al 2004; Tomy et al 2004). It has to be noted that PFOS may therefore be the final degradation or metabolic product of many perfluorooctylsulfonyl substances (Hekster et al 2003).

Bioaccumulation occurs also in humans, and everybody in our society has traces of these PFCs in their blood and internal organs such as the liver, kidneys, spleen, gall bladder and testes. In the blood, PFOS and PFOA are bound to serum proteins. The acute toxicity of the polyfluorinated substances is moderate but some substances can induce peroxisome proliferation in rat livers and may change the fluidity of cell membranes. Some of these PFCs, such as PFOS and PFOA, are potential developmental toxicants and are suspected endocrine disruptors with effects on sex hormone levels resulting in lower testosterone levels and higher oestradiol level. Other PFCs have oestrogenic effects in cell cultures (Ensen et al 2008). The persistence of PFCs in the environment, plus their potential to accumulate in organisms and to biomagnify in the food chain is of particular toxicological concern. Several PFCs have been detected in nearly all environmental media and biota reflecting the widespread global pollution in all parts of the ecosystem (Giesy and Kannan 2001). The toxicity of PFOS and PFOA has been studied extensively, mainly in rodents. Several reviews are available that discuss results from these studies (OECD 2002; Kennedy et al, 
2004; US EPA, 2005; Harada et al, 2005b; Andersen et al, 2008; Lau et al, 2007).

Top predators are sensitive to persistent and bioaccumulative contaminants such as PFCs, due to their high trophic position in the food web (Martin et al 2004; Haukas et al 2007). Bird eggs had been traditionally used as indicators of environmental contamination and most of the current information on PFCs concentrations comes from this biological indicator collected widely in Northern Hemisphere (Kannan et al 2001a; Van de Vijver et al 2005; Ishibashi et al 2008b; Gebbink et al 2009). Little is known about the status and temporal trend of PFC contamination in tissues of avian top food-chain models from Lake Ontario in the Great Lakes.

It has recently been shown that PFOS does not affect the regulatory functions of the thyroid hormone system itself, but it is the competitive binding to transport proteins that alters the free thyroxine (T4) levels in blood (Chang et al 2008; Lau et al 2007). THs have been show to be associated (not covalently bound) to transport proteins such as transthyretin (TTR). This TTR-TH complex functions as a circulating reservoir to buffer changes in thyroid hormone levels. TTR is not only a highly conservative plasma protein and the main T4 carrier in cerebrospinal fluid (CSF) but also important in serum of birds (Weiss et al 2009). 
The aim of this study was to screen the affinity of perfluorinated complex mixtures (acidic and neutral) obtained from liver extraction and to test two representative compounds found in the two mixtures, as single congeners for binding affinity. Binding studies using commercially available human TTR and PFCs had been reported recently by Weiss et al (2009). The intend of this chapter is to contribute with novel knowledge to a better understanding of PFCs affinities for $\mathrm{TH}$, and the possibility of a toxic mode of action; using selected relevant complex chemical mixtures (extracted from livers). In this examination, cloned, expressed and purified TH transport proteins TTR and albumin from Herring gull (Larus argentatus) will be used. The set of PFCs representing the complex mixtures will be selected for testing according to their presence in livers and their environmental relevance.

\subsection{Results and Discussion}

\subsubsection{Comparison of sites and contaminants}

The C6, Cs and C10 PFSAs were detected in the herring gull livers and dominated by PFOS (Cs), which comprised $>90 \%$ of the £PFSA. This finding is consistent with recent reports of £PFSA $j_{n}$ herring gulls eggs from the Great Lakes (Gebbink et al 2009), also similar result was reported for the contribution of PFOS to IPFSA concentration livers of glaucous gulls (Larus hyperboreus) from the Norwegian Arctic and herring gull eggs from northern Norway (>97\%) (Verreault et al 2005, 2007). 
The concentrations of PFCs found in the livers of herring gulls from the Hamilton Harbour colony in this study are $>2$-fold compared to the concentration found by Gebbink et al (2009) in eggs $(319 \pm 32 \mathrm{ng} / \mathrm{g} \mathrm{ww})$ who also used colonied of birds from the Great Lakes. This concentration it is consistent with the chemical pattern recently reported in fish [the alewife (Alosa pseudoharengus) and rainbow smelt (Osmerus mordax)] (Martin et al 2004) where PFSA patterns were similar to those observed here. The alewife and smelt are a major component in the aquatic diet of the herring gulls from the Great Lakes (Hebert et al 1999).

No significant differences among sites were observed for £PFSA concentration levels; Scotch Bonnet Island had 709.05 ng/g ww and Hamilton Harbour 686.95. A small increase in the £PFSA concentration was observed, however, the concentration levels of PFDS where in SBI $0.001 \%$ and in $\mathrm{HH} 0.48 \%$ from the total £PFSA. Perfluorodecanoic acid (PFDA) is a breakdown product of stainand grease-proof coatings on food packaging, couches, and carpets, including Stainmaster. The chemical is part of a family of perfluoroalkyl carboxylates, all with structures similar to the well-known chemical contaminant PFOA, but with carbon chain lengths ranging from 4 to 15 carbons. PFDA is the 10 carbon version of PFOA. All of these perfluoroalkyl carboxylates are highly persistent. But those with carbon chain lengths of at least 8 carbons are of particular concern because they are known to be bioaccumulative, globally distributed pollutants. These chemicals have been found in human and wildlife blood and tissues from around the globe, even in remote locations such as the arctic (e.g. 
Common Guillemot (Uria aalge) (Holmstrom and Berger 2008). It is possible that this compound is highly persistent in biota, consequently the highest urban exposure of Hamilton Harbour, make the difference in concentrations compared to SBI.

XPFCA concentrations in the other hand, presented differences $(p<0.05)$ between $\mathrm{SBI}$ and Hamilton Harbour. In this analysis PFUdA in SBI was $57.4 \%$ of the total £PFCA and $\mathrm{HH}$ registered $25.5 \%$. Considering that PFUdA is a breakdown product of stain- and grease-proof coatings on food packaging, couches, carpets. This 11-carbon version of PFOA is considered to be very persistent; and bioaccumulative, is surprising to found that the higher urban exposed bird colony had half of the concentration of herring gull livers at SBI. Asociations among feeding patterns could be also added to this discussion, while birds in urban areas tend to have a more diverse diet oriented to human waste, in $\mathrm{SBI}$ agricultural and dump near vicinity bird range of feeding could be a factor.

Total concentrations levels of PFNA (that is another breakdown product of stainand grease-proof coatings on food packaging, couches, carpets; a 9-carbon version of PFOA; persistent; bioaccumulative) in SBI were lower (7\%), than $\mathrm{HH}$ (39.6\%) related to the £PFCAs. SBI concentration of PFTrDA were $01.5 \%$, while $\mathrm{HH}$ had not detectable levels registered.

Hickey et al (2009) recently analyzed five of the PFCAs here detected (PFNA, PFDA, PFUnDA, PFDoDA, and PFTrDA) and reported that this compounds 
induced liver fatty acid-binding protein (L-FABP) at concentrations of 10 or 50 $\mathrm{uM}$; the strongest inducer of L-FABP was PFUnDA, with a 23-fold level of induction at a concentration of $10 \mathrm{uM}$. Also, at concentrations of 10 or $50 \mathrm{uM}$, six of the PFCAs (PFPeA, PFHA, PFNA, PFUnDA, PFTrDA, and PFTeDA) induced EROD activity (a measure of the catalytic activity of CYP1A4 in chicken) mRNA. The authors also mention that the only PFCAs that affected Cytochrome P450 4B1 is a protein that is encoded by the CYP4B1 gene (CYP4B1) expression (regulator of xenobiotic metabolism) were PFNA (induced) and PFTrDA (repressed)

XPFCAs with chain length of $\mathrm{Cg}-\mathrm{Cn}$ and $\mathrm{C} 13$ were measurable in the herring gull livers, and PFUdA, PFDA and PFNA dominated the £PFCA, this differs from Gebbink et al, (2009) publication who analyzed eggs from Hamilton Harbour and where PFUnA and PFTrA dominated the PFCA pattern in the eggs for the same site. This could be related to the mechanistic excresion of the liver compared to eggs, where female birds excret high amount of contaminants attached to the albumin of the egg, due to the lipophylic characteristics of PFCAs. The £PFCAs found in this study, are also lower compared to the values described by Gebbink et al (2009) in eggs of herring gulls (where bioaccumulation is very possible), and the authors reported that £PFCA was $56 \pm 8 \mathrm{ng} / \mathrm{gr}$ ww..

There are many similarities among the concentration found in livers, with previous data published with PFCs in eggs of herring gulls at the Great Lakes by 
Gebbink et al (2009). However related to the main differences observed among the two bird colonies, the source of the contaminants present are attributed mainly to that the areas represented a high populated, urban and industrialized parts of the Great Lakes $(\mathrm{HH})$, and a more rural inside lake bird colony $(\mathrm{SBI})$.

\subsubsection{Complex chemical mixtures from neutral and acidic extraction}

Complex mixture of neutral fraction (including PFOSA, values in table 7) was observed to have highest affinity and displacement of the binding of T4 and human TTR, but a small effect was observed when binding gull TTR. Also gull TTR have a small interruptio of T3, however, human TTR had a brief binding disruption with $\mathrm{T} 3$ binding $\mathrm{TH}$ transport proteins in presence of the neutral complex mixture. Albumin was the $\mathrm{TH}$ transport protein more affected by the complex mix, repeating the same effects in human and herring gulls (Figure 22). This could be related that albumin is a relatively non-selective transport protein found in all vertebrates (in this study birds and mammals). As the most abundant plasma protein, albumin's blood concentration often far exceeds even the flavonoids that flood the bloodstream after sugars are is metabolism. Although albumin is not strongly attracted to particular molecules, there is a complex molecular interaction in the blood and the PFCs are transported due to their lipophilic molecular characteristics and similar chemical structure with fatty acids (FAs). 
The structure of many PFCs and their behavior within the body of organisms are comparable to free FAs, and as such they bind to liver FA-binding protein, and the protein albumin, which is mainly present in blood, liver, and eggs (Jones et al 2003; Luebker et al 2002; Martin et al 2003). It is suggested that the polar hydrophobic nature of fluorine containing compounds can lead to increased affinity for proteins, despite the relatively weak dipolar interactions that characterize the hard C-F dipole. The polar hydrophobic concept can explain some of the protein-binding data characteristics of fluorinated compounds (Biffinger et al 2004).

PFOSA is a known precursor to PFOS and was measurable in all herring gull livers in this study. Environmental research initially focused on the compound perfluorooctane sulfonate (PFOS) and perfluorooctanoic acid (PFOA), the perfluorinated contaminants predominantly analyzed and found in the environment. Recently, a variety of other PFCs are being found worldwide in the environment, animals, and humans from urban to remote areas in all trophic levels (Houde et al 2006; Kallenborn et al 2004; Kannan et al 2004; Lau et al 2007; van Leeuwen et al 2006).

PFOSA as single congener in competitive binding assay (Figure 24) disrupt human TTR binding T4, but a difference of what was observed in their correspondent chemical fraction, PFOSA does no have effect in albumin, independently is was from human or bird when binding T4. Therefore, other 
factors of unknown affinity are affecting the THs and albumin, and an increased disruption of $T_{3}$-albumin appears to take place when albumin had a competitive interaction with PFOSA.

The Acidic fractions (including PFBs, PHxS, PFOS, PFDA and PFudA; table 8) was assayed with T3 and T4 and binding interaction with gull and human TTR and ALB. Relative to control group the acidic fraction displaced $T_{4}$ from binding human TTR (Figure 23). The affinity observed among human and herring gull albumin exposed to the chemical neutral fraction competitive binding (Figure 23) differs from acidic extraction; where neutral fraction had a higher affinity for $\mathrm{T} 4$, affecting human and gull albumin $\mathrm{TH}$ transport protein.

Biomonitoring surveys analyzing fish-eating birds demonstrated that the most elevated PFCA and PFSA besides PFOA and PFOS were the longer chained perfluoroundecanoic acid (PFUdA) and perfluorodecane sulfonate (PFDS), respectively (Bustnes et al, 2008; Butt et al, 2007; Holmstrom and Berger, 2008; Houde et al, 2006; Lofstrand et al, 2008; Tao et al, 2006; Verreault et al, 2005, 2007; Wang et al, 2008). PFUdA was selected in relation to an acidic fraction to examine the competitive binding assay affinity with TH and TTR and albumin (Figure 25). PFUdA in this study had binding affinity effects on $T_{4}$ in both human and herring gull TH transport proteins. Also the possibility of the longer chain of PFCs, the most involve of cytochrome P450 (CYP102) can be inlvove since branched chain fatty acids are substrates for CP450. 
Table 7 Arithmetic Mean Concentration of £PFSA (ng/g wet weight) in individual Herring gull livers collected from two colonies in the Great lakes; Hamilton Harbour $(\mathrm{HH})$ and Scotch Bonnet Island (SBI).

\begin{tabular}{|l|l|l|l|l|}
\hline Site SBI & Average & SE & Min & Max \\
\hline PFBS & 0 & 0 & 0 & 0 \\
\hline PFHxS & 0 & 0 & 0 & 0 \\
\hline PFOS & 707.801 & 58.036 & 341.585 & 1151.703 \\
\hline PFDS & 0.014 & 0.009 & 0 & 0.117 \\
\hline FOSA & 1.241 & 0.0903 & 0.691 & 1.671 \\
\hline IPFSA & 709.055 & 58.084 & 342.275 & 1153.153 \\
\hline & & & & \\
\hline Site HH & Average & SE & Min & Max \\
\hline PFBS & 0 & 0 & 0 & 0 \\
\hline PFHxS & 0 & 0 & 0 & 0 \\
\hline PFOS & 681.502 & 70.801 & 337.249 & 1116.881 \\
\hline PFDS & 3.324 & 1.941 & 0 & 19.088 \\
\hline FOSA & 2.131 & 0.232 & 0.841 & 3.021 \\
\hline IPFSA & 686.957 & 70.787 & 338.089 & 1119.882 \\
\hline
\end{tabular}


Neutral extraction

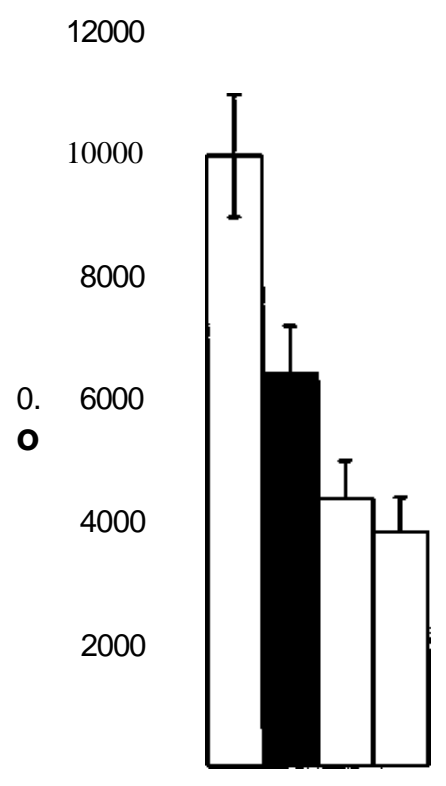

$\mathrm{H}-\mathrm{TTR}$

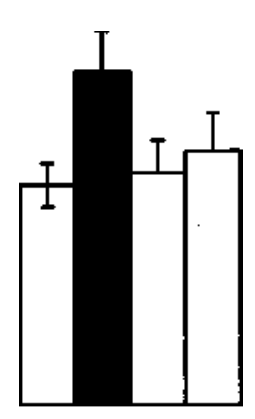

G-TTR

- T4

- T3

- Control T4

- Control T3

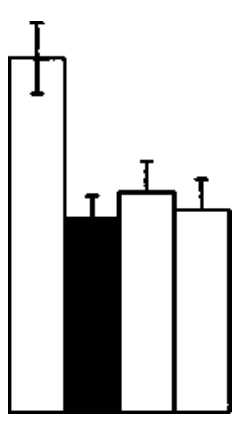

H-ALB

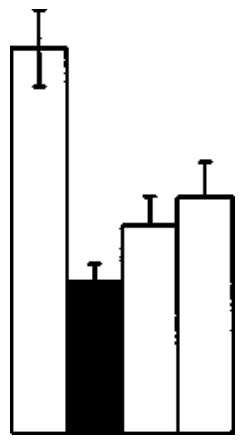

G-ALB

Figure 22. Human or Gull Albumin and Transthyretin (TTR): Competitive binding of Neutral PFC-containing fractions from L. Ont. Herring gull Liver with 3,3',5triiodo-L-thyronine $\left(\mathrm{T}_{3}\right)$ and S.S.S'.S'-tetra-iodothyronine or thyroxine $\left(\mathrm{T}_{4}\right) ; \mathrm{CPM}$, counts per minute $-\mathrm{IT} 4$ and ${ }^{125}-\mathrm{IT}_{3}$. 
Table 8. Arithmetic Mean Concentration of £PFCA ( $\mathrm{ng} / \mathrm{g}$ wet weight) in individual Herring gull livers collected from two colonies in the Great lakes in; Hamilton Harbour $(\mathrm{HH})$ and Scotch Bonnet Island $(\mathrm{SBI})$.

\begin{tabular}{|l|l|l|l|l|}
\hline Site SBI & Average & SE & Min & Max \\
\hline PFHxA & 0 & 0 & 0 & 0 \\
\hline PFHpA & 0 & 0 & 0 & 0 \\
\hline PFOA & 0 & 0 & 0 & 0 \\
\hline PFNA & 1.407 & 0.628 & 0 & 7.282 \\
\hline PFDA & 6.763 & 1.081 & 0 & 12.048 \\
\hline PFUdA & 11.414 & 2.193 & 0.032 & 24.745 \\
\hline PFDoA & 0 & 0 & 0 & 0 \\
\hline PFTrDA & 0.298 & 0.217 & 0 & 2.386 \\
\hline PFTeDA & 0 & 0 & 0 & 0 \\
\hline PFPA & 0 & 0 & 0 & 0 \\
\hline IPFCA & 19.883 & 3.345 & 0.888 & 36.649 \\
\hline & & & & \\
\hline Site HH & Average & SE & Min & Max \\
\hline PFHxA & 0 & 0 & 0 & 0 \\
\hline PFHpA & 0 & 0 & 0 & 0 \\
\hline PFOA & 0.193 & 0.193 & 0 & 1.936 \\
\hline PFNA & 3.775 & 1.283 & 0 & 12.429 \\
\hline PFDA & 5.516 & 1.313 & 0 & 11.816 \\
\hline PFUdA & 3.262 & 0.822 & 0 & 7.818 \\
\hline PFDoA & 0 & 0 & 0 & 0 \\
\hline PFTrDA & 0 & 0 & 0 & 0 \\
\hline PFTeDA & 0 & 0 & 0 & 0 \\
\hline PFPA & 0 & 0 & 0 & 0 \\
\hline IPFCA & 12.748 & 3.260 & 0 & 30.202 \\
\hline & & & & \\
\hline
\end{tabular}


Acidic Extraction
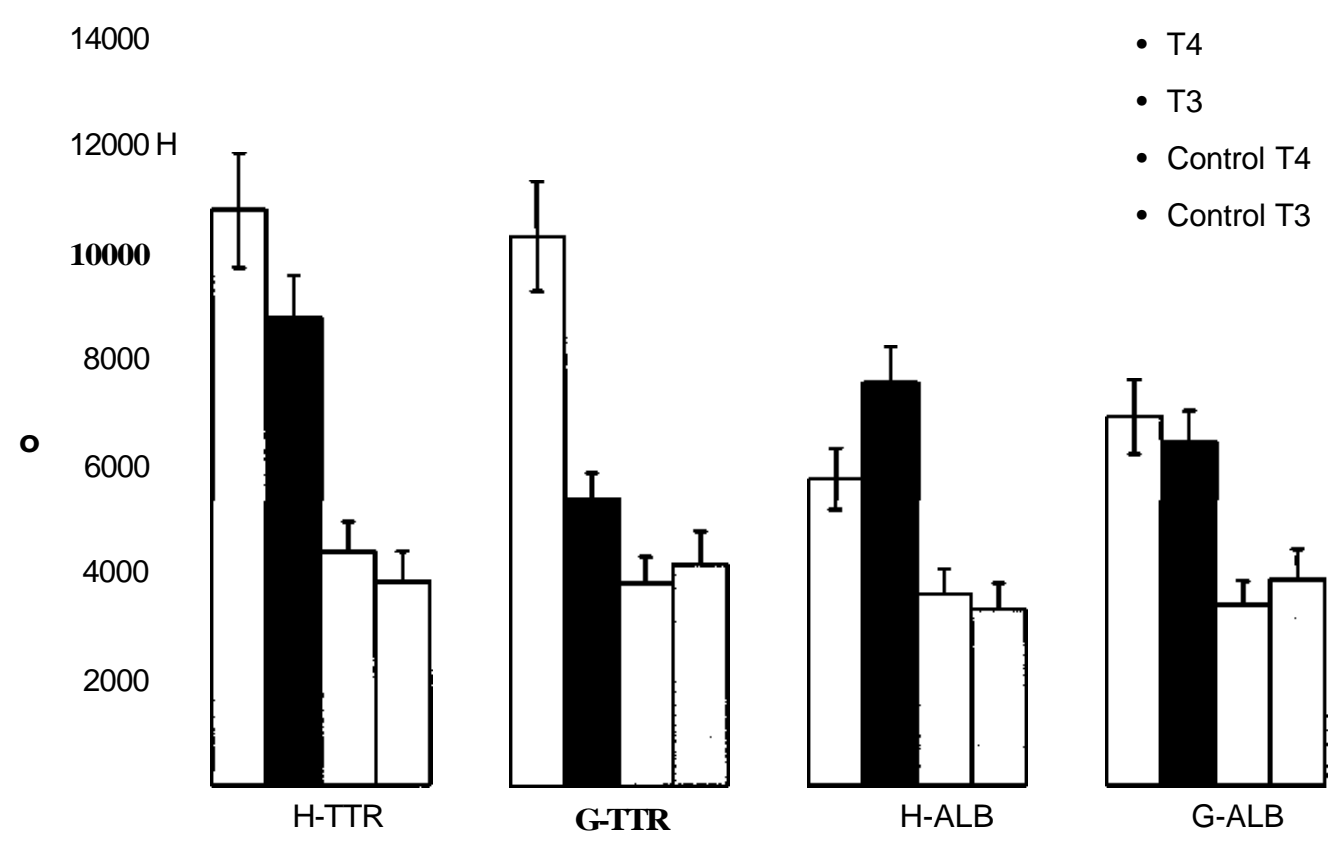

Figure 23. Human or Gull Albumin and Transthyretin (TTR): Competitive binding of Acidic fraction PFC-containing fractions from L. Ont. Herring gull Liver with 3,3',5-triiodo-L-thyronine ( $\left.T_{3}\right)$ and S.S.S'.S'-tetra-iodothyronine or thyroxine (T4) ); CPM, counts per minute $-\mathrm{IT}_{4}$ and ${ }^{125}-\mathrm{IT}_{3}$. 
Albumin is one $\mathrm{TH}$ transport protein that is relatively non-selective for hormones in avian species and found at high concentrations in the blood (Baker, 2002), and serves as an important regulator of bioavailability, binding approximately $10 \%$ of circulating THs in humans (Benvenga et al, 2002) and contrary to humans is the major circulating $\mathrm{TH}$ transport protein in birds (75\%), herbivorous marsupials and small eutherians (Richardson et al, 1994; 1996). Since PFCAs are structurally homologous to free fatty acids (Luebker et al 2002) and are expected to present affinity for for serum protein binding sites in vivo (Jones et al 2003). Jones et al, 2003 proposed that circulating serum albumin also tightly binds PFCs.

The complexity of fatty acids is a factor also, to be considered when the interaction of wide variety of PFCs are directly involve in the transportation of $\mathrm{TH}$ transport proteins such as TTR and albumin. For example, halogenated fatty acids which are one of the most interesting groups among the naturally occurring halogen compounds are not well known but several reviews on these compounds may be found. Halogenated fatty acids are found in different groups of organisms from microorganisms to the highest plants and animals. As halogen, they contain one or several atoms of fluor, chlorine, or bromine, and their interaction with $\mathrm{TH}$ transporters and their possible disruption by PFCs are not fully understood. 
PFOSA

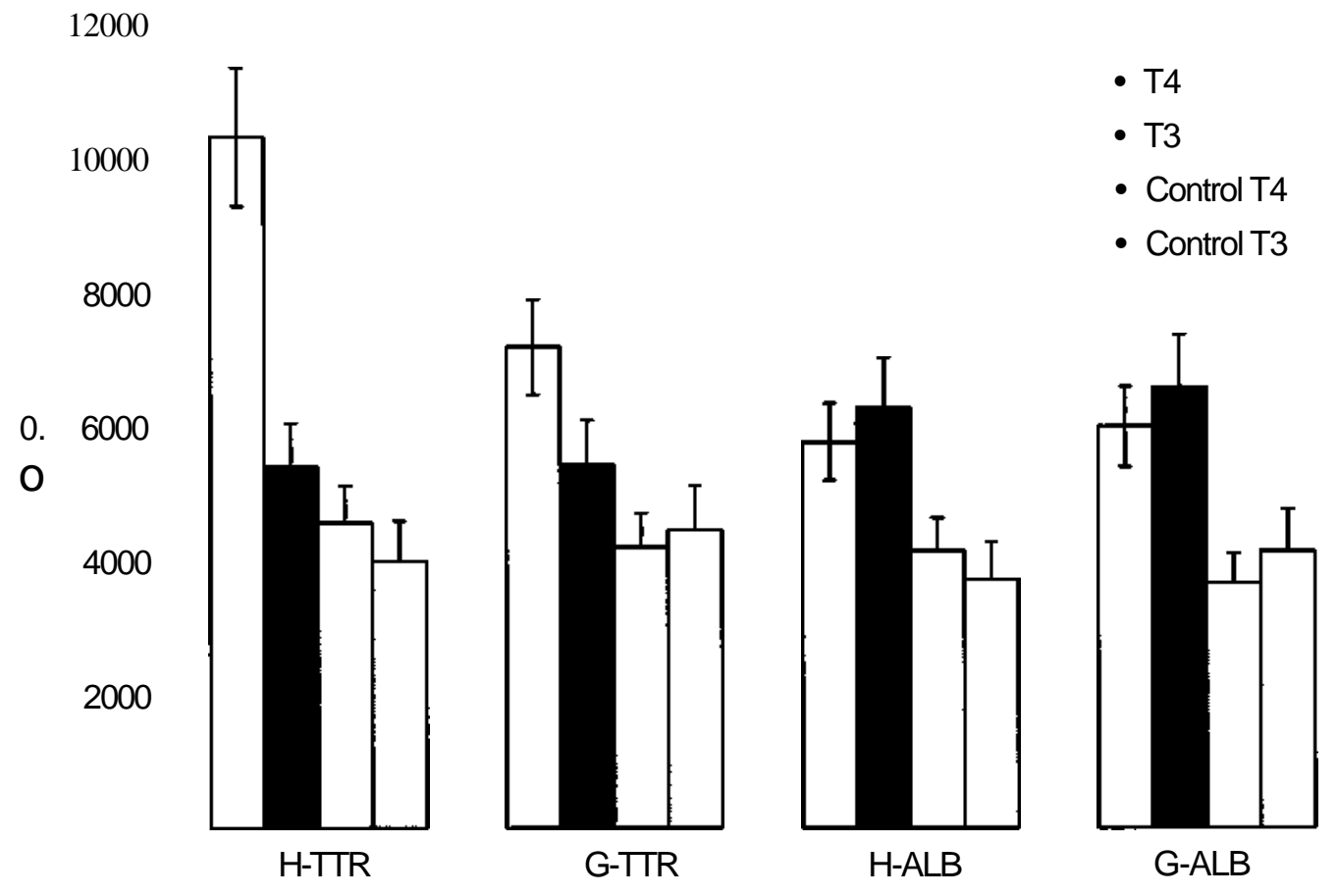

Figure 24. Human or Gull Albumin and Transthyretin (TTR): Competitive binding of Perfluorooctane sulfonamide (PFOSA) $\mathrm{CF}_{3}\left(\mathrm{CF}_{2}\right) 7 \mathrm{~S} 02 \mathrm{NH}_{2}$ with 3,3',5-triiodo-Lthyronine $\left(T_{3}\right)$ and 3,5,3',5'-tetra-iodothyronine or thyroxine $\left.\left(T_{4}\right)\right)$; CPM, counts per minute ${ }^{\mathrm{n} 25}-\mathrm{IT}_{4}$ and ${ }^{125}-\mathrm{IT}_{3}$ 


\section{PFUdA/C11}

16000 -

14000

12000 -

10000 -

Q. 8000

O

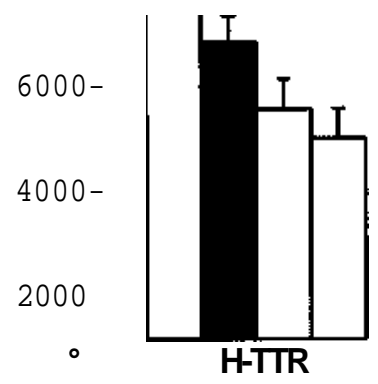

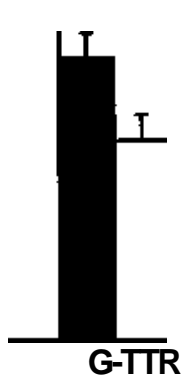

DT4

- T3

D Control T4

D Control T3

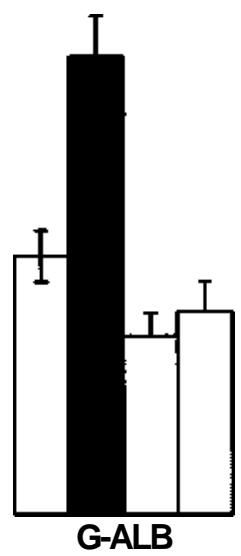

Figure 25. Human or Gull Albumin and Transthyretin (TTR): Competitive binding of Perfluoroundecanoic acid (PFUdA) $\mathrm{CF}_{3}\left(\mathrm{CF}_{2}\right) 9 \mathrm{CO}_{2} \mathrm{H}$ (Cn chain length) with 3,3',5-triiodo-L-thyronine $\left(T_{3}\right)$ and S.S.S'.S'-tetra-iodothyronine or thyroxine $\left(T_{4}\right)$ ); CPM, counts per minute ${ }^{1}-\mathrm{IT}_{4}$ and ${ }^{125}-\mathrm{IT}_{3}$. 
Even no statistically significant associations were detected, following post hoc power analyses raised the possibility for positive associations between FT4, PFDA and PFUdA, to be detected with moderate increases. In this study displaced $T_{3}$ from binding herring gull albumin by PFUdA was observed. PFuDA (C11) had disrupting effects when albumin in gulls binds $T_{3}$ and $T_{4}$, while in human albumin no effect was observed, suggesting a more disrupting predisposition of albumin in birds than humans to PFCs.

Thyroid hormones play critical roles in human and avian neurodevelopment and adult neurocognitive function. POPs, such as PFCs tested in this competitive assays, may interfere with thyroid homeostasis and thus exposures to these compounds might represent risk factors for neurological and cognitive abnormalities. In a recent study, Bloom et al (2009) explored the potential associations between body burdens of six perfluorinated compounds, and their sum, with thyroid stimulating hormone (TSH) and FT4 among 31 licensed New York State anglers, using a cross-sectional study design, results of the study raise the possibility for associations for $\mathrm{FT}(4)$ with PFDA and PFUnDA, PFCs measured in low concentrations (Blooms et al 2009). Given the ubiquity of PFCs in the environment and the importance of thyroid function to neurodevelopment and neurocognitive endpoints. 
In another study, Dellaire et al (2009) examined Adult Inuit (indigenous population north of Canada) plasma and found a negative association of PFOS concentrations with circulating $\mathrm{TSH}, \mathrm{tT}_{3 \mathrm{i}}$ and $\mathrm{TBG}$ levels and a positive relationship with $\mathrm{fT}_{4}$. Toxicological studies dedicated to investigating the thyroiddisrupting properties of PFOS are rare and focus mainly on maternal and fetal thyroid functions. In adult rats, PFOS was shown to compete with $\mathrm{fT}_{4}$ for transport proteins (Chang et al 2008), leading to a transient increase in $\mathrm{fT}^{*}$ and decrease in TSH concentrations. However, Dellaire et al (2009) also found a nontransient reduction in $\mathrm{fT}_{4}$ and $\mathrm{tT} 3$, with the latter being less affected. These results in laboratory animals are consistent with perturbations observed on the TH homeostasis in the Inuit.

PFOS are widely distributed and persistent in the environment and in wildlife, and it has the potential for developmental toxicity; consequenty it is recommended to develop more studies studying the interaction of PFOs with $\mathrm{TH}$ s and $\mathrm{TH}$ transport proteins. Since the molecular mechanisms that lead to these toxic effects are not well known, a new line of research is intending to address these unknown mechanisms. In a recent study, Xiongjie et al (2009) performed a proteomic analysis to investigate the proteins that are differentially expressed in zebrafish embryos exposed to $0.5 \mathrm{mg} / \mathrm{l}$ PFOS until $192 \mathrm{~h}$ post-fertilization. The analysis revealed that of 69 proteins used, all of them showed altered expression in the treatment group compared to control group with either increase or decrease in expression levels (more than two-fold differences). The study use proteins and 
categorized them into diverse functional classes such as detoxification, energy metabolism, lipid transport/steroid metabolic process, cell structure, signal transduction, and apoptosis. Overall, proteomic analysis using zebrafish embryos serves as an in vivo model in environmental risk assessment and provides insight into the molecular events in PFOS-induced developmental toxicity. Since TH Transport proteins are strictly related to the supply of $T_{3}$ and $T 4$ vital for intracellular process, the effect in the post-transcription of proteins could also be related to the increase, decrease or disruption of the transportation affinities of albumin and TTR.

\subsubsection{Conclusions}

Perfluorinated compounds (PFCs) analyzed in this study through their complex chemical fractions (neutral and acidic extractions) were able to disrupt the binding of T3 and T4 with TH transport Proteins TTR and albumin. Differences were observed in the response of $\mathrm{TH}$ transport proteins between humans and herring gulls (and between fractions. The acidic fraction was able to disrupt human and gull TTR binding T3 and T4. Neutral extraction have disruption effect in T4 binding human and gull albumin, and also TTR from human origin. Competitive assays with PFOSA show disruption of human TTR when binding T4. While PFUdA affected human and gull TTR when binding T4, but not for T3. This chapter contributes with novel data of PFCs concentration levels in livers of Herring gulls (Larus argentatus) from the Great Lakes, from two bird colonies (Hamilton Harbour and Scotch Bonnet Island) in Lake Ontario, Canada. 


\subsection{References}

Andersen ME, Butenhoff JL, Chang SC, Farrar DG, Kennedy GL, Lau C, Olsen GW, Seed J, Wallace KB, 2008. Perfluoroalkyl acids and related chemistries toxicokinetics and modes of action, Toxicol. Sci. 102 (2008), pp. 3-14.

Baker ME. 2002. Albumin, steroid hormones and the origin of vertebrates. Journal of Endocrinology (2002) 175, 121-127

Benvenga S, Thyroxine binding to members and non-members of the serine protease inhibitor family, J Endocrinol Investig 25 (2002), pp. 32-38.

Bloom MS, Kannan K, Spliethoff HM, Tao L, Aldous KM, Vena JE, 2009.

Exploratory assessment of perfluorinated compounds and human thyroid function. Physiology \& behavior. 01/03/2009; ISSN: 0031-9384 accesed December 9, 2009

Bustnes, J.O., Borga, K., Erikstad, K.E., Lorentsen, S.H., Herzke, D., 2008. Perfluorinated, brominated, and chlorinated contaminants in a population of lesser black-backed gulls (Larus fuscus). Environ. Toxicol. Chem. 27, 13831392.

Butt, CM., Mabury, S.A., Muir, D.C., Braune, B.M., 2007. Prevalence of longchained perfluorinated carboxylates in seabirds from the Canadian Arctic between 1975 and 2004. Environ. Sci. Technol. 41, 3521-3528.

Chang, S.-C, Thibodeaux, J. R., Eastvold, M. L, Ehresman, D. J., Bjork, J. A., Froehlich, J. W., Lau, C, Singh, R. J., Wallace, K. B., and Butenhoff, J. L. (2008). Thyroid hormone status and pituitary function in adult rats given oral doses of perfluorooctane sulfonate (PFOS). Toxicology 243, 330-339.

Shaogang C, Letcher RJ, 2008. Analysis of fluorotelomer alcohols and perfluorinated sulfonamides in biotic samples by liquid chromatographyatmospheric pressure photoionization mass spectrometry. Journal of chromatography. A 2008; 1215(1-2):92-9.

Dallaire R, Dewailly E, Pereg D, Dery S, Ayotte P, 2009. Thyroid Function and Plasma Concentrations of Polyhalogenated Compounds in Inuit Adults. Environm Health Perspect 117(9): 1380-1386.

D'eon JC, Mabury SA, Production of perfluorinated carboxylic acids (PFCAs) from the biotransformation of perfluoroalkyl phosphate surfactants (PAPS): exploring routes of human contamination, Environ. Sci. Technol. 41 (2007), pp. $4799^{\wedge} 805$. 
Dinglasan MJ, Yeh Y, Edwards EA, Mabury SA, 2004. Fluorotelomer alcohol biodegradation yields poly- and perfluorinated acids, Environ. Sci. Technol. 38 (2004), pp. 2857-2864.

Ensen AA, Leffers H, Swan S, Soder O, 2008. Emerging endocrine disrupters: perfluoroalkylated substances. Copenhagen Workshop on Endocrine Disrupters №4, DANEMARK (28/05/2007), 31(2): 223.

Ellis DA, Martin JW, De Silva AO, Mabury SA, Hurley MD, Andersen MDS, Wallington TJ. 2004. Degradation of fluorotelomer alcohols: a likely atmospheric source of perfluorinated carboxylic acids, Environ. Sci. Technol. 15 (2004), pp. 3316-3321.

EU (European Union), 2006. Directive 2006/122/ECOF of the European Parliament and of the Council of 12 December 2006. Official Journal of the European Union, L/372/32-34, 27.12.2006.

Fasano WJ, Carpenter SC, Gannon SA, Snow TA, Stadler SC, Kennedy GL, Buck RC, Korzeniowski SH, Hinderliter PM, Kemper RA, 2006.Absorption, distribution, metabolism, and elimination of 8-2 fluorotelomer alcohol in the rat, Toxicol. Sci. 91 (2006), pp. 341-355.

Fromme H, Tittlemier SA, Volkel W, Wilhelm M, Twardella D. 2009. Perfluorinated compounds - Exposure assessment for the general population in western countries. International Journal of Hygiene and Environmental Health, Volume 212(3): 239-270.

Furdui, V. I.; Stock, N. L; Ellis, D. A.; Butt, C. M.; Whittle, D. M.; Crazier, P. W.; Reiner, E. J.; Muir, D. C. G.; Mabury, S. A. Spatial distribution of perfluoroalkyl contaminants in lake trout from the Great Lakes. Environ. Sci. Technol. 2007, 41, 1554-1559.

Furdui, V. I.; Helm, P. A.; Crazier, P. W.; Lucaciu, C; Reiner, E. J.; Marvin, C. H.; Whittle, D. M.; Mabury, S. A.;Tomy,G. T. Temporal trends of perfluoroalkyl compounds with isomer analysis in lake trout from Lake Ontario (1979-2004). Environ. Sci. Technol. 2008, 42, 4739-4744.

Gebbink WA., Hebert C, Letcher RJ. 2009. Perfluorinated Carboxylates and Sulfonates and Precursor Compounds in Herring Gull Eggs from Colonies Spanning the Laurentian Great Lakes of North America. Environ. Sci. Technol. 2009, 43, 7443-7449.

Giesy PJ, Kannan K, Global distribution of perfluorooctane sulfonate in wildlife, Environ Sci Technol 35 (2001), pp. 1339-1342. 
Government of Canada, 2006. Perfluorooctane sulfonate and its salts and certain other compounds regulations, Can. Gazette Pt. 1140 (50) (2006), pp. 42654284.

Harada K, Nakanishi S, Saito N, Tsutsui T, Koizumi A, 2005a. Airborne perfluorooctanoate may be a substantial source contamination in Kyoto area, Japan, Bull. Environ. Contam. Toxicol. 74 (2005), pp. 64-69.

Harada K, Inoue K, Morikawa A, Yoshinaga T, Saito N, Koizumi A, 2005b. Renal clearance of perfluorooctane sulfonate and perfluorooctanoate in humans and their species-specific excretion, Environ. Res. 99 (2005), pp. 253-261.

Haukas, M., Berger, U., Hop, H., Gulliksen, B., Gabrielsen, G.W. (2007): Bioaccu-mulation of per- and polyfluorinated alkyl substances (PFAS) in selected species from the Barents Sea food web. Environ. Pollution 148 (1), S. 360-371

Hebert, C. E. Winter severity affects migration and contaminant accumulation in northern Great Lakes Herring Gulls. Ecol. Appl. 1998, 8, 669-679

Hebert, C.E., J.L. Shutt, K.A. Hobson, and D.V. Weseloh. 1999. Spatial and temporal differences in the diet of Great Lakes herring gulls (Larus argentatus): Evidence from stable isotope analysis. Canadian Journal of Fisheries and Aquatic Sciences 56:323-338.

Hebert, C.E., and H.A. Morrison. 2003. Consumption offish and other prey items by Lake Erie waterbirds. Journal of Great Lakes Research. 29(2):213-227.

Hebert, C.E., J.L. Shutt, and R.O. Ball. 2002. Plasma amino acid concentrations as an indicator of protein availability to breeding herring gulls (Larus argentatus). Auk` 19:185-200. $^{\wedge}$

Hekster FM, Laane RW, de Voogt P. 2003. Environmental and toxicity effects of perfluoroalkylated substances, Rev. Environ. Contam. Toxicol. 179 (2003), pp. $99-121$

Henderson WM, Smith MA. 2007. Perfluorooctanoic acid (PFOA) and perfluorononanoic acid (PFNA) in fetal and neonatal mice following in utero exposure to 8-2 fluorotelomer alcohol (FTOH), Toxicol. Sci. 95 (2007), pp. 462473.

Hickey NJ, Crump D, Jones SP, Kennedy SW, 2009. Effects of 18 Perfluoroalkyl Compounds on mRNA Expression in Chicken Embryo Hepatocyte Cultures. Toxicological Sciences 111(2): 311-320. 
Holmstrom, K.E., Berger, U., 2008. Tissue distribution of perfluorinated surfactants in common guillemot (Uria aalge) from the Baltic Sea. Environ. Sci. Technol. 42, 5879-5884.

Houde, M., Martin, J. W., Letcher, R. J., Solomon, K. R., and Muir, D. C. G. (2006). Biological monitoring of polyfluoroalkyl substances: A review.

Environ. Sci. Technol. 40(11), 3463-3473.

Holmstrom KE, Berger U, 2008. Tissue Distribution of Perfluorinated Surfactants in Common Guillemot (Uria aalge) from the Baltic Sea. Environ Sci Technol 42(16): 5879-5884.

Ishibashi H, Iwata H, Kim, Tao L, Kannan K, Amano M, et al., 2008b. Contamination and effects of perfluorochemicals in Baikal Seal (Pusa sibirica) I: Residue level, tissue distribution, and temporal trend, Environ Sci Technol 42 (2008), pp. 2295-2301.

Ishibashi H, Iwata H, Kim EY, Tao L, Kannan K, Tanabe S, et al., 2008a. Contamination and effects of perfluorochemicals in Baikal Seal (Pusa sibirica) II: Molecular characterization, expression level and transcriptional activation of peroxisome proliferator-activated receptor a, Environ Sci Technol 42 (2008), pp. 2302-2308.

Jones PD, Hu W, De Coen W, Newsted JL, Giesy JP, Binding of perfluorinated fatty acids to serum proteins, Environ Toxicol Chem 22 (2003), pp. 2639-2649.

Kallenborn, R., Berger, U., and Ja'rnberg, U. (2004). Perfluorinated alkylated substances (PFAS) in the Nordic environment. TemaNord. 2004, 552.

Kannan K, Franson JC, Bowerman WW, Hansen KJ, Jones PD, Giesy JP, 2001a. Perfluorooctana sulfonate in fish-eating water birds includine Bald Eagles and Albatrosses, Environ Sci Technol 35 (15) (2001), pp. 3065-3070.

Kannan K, Koistinen J, Beckmen K, Evans T, Gorzelany JF, Hansen KJ, et al., 2001b. Accumulation of perfluorooctane sulfonate in marine mammals, Environ Sci Technol 35 (8) (2001), pp. 1593-1598.

Kannan, K., Corsolini, S., Falandysz, J., Fillman, G., Senthil Kumar, K., Logonathan, B. G., AN Mohd, M., Oliviero, J., van Wouwe, N., Yang, J. H., et al. (2004). Perfluorooctane sulfonate and related fluorochemicals in human blood from several countries. Environ. Sci. Technol. 38, 4489-4495.

Kissa E, 2001. Fluorinated Surfactants and Repellents (second ed), Marcel Dekker, Inc., New York, NY, USA (2001) pp. 1-615. 
Kudo N, Iwase Y, Okayachi H, Yamakawa Y, Kawashima Y, 2005. Induction of hepatic peroxisome proliferation by 8-2 telomer alcohol feeding in mice: formation of perfluorooctanoic acid in the liver, Toxicol. Sci. 86 (2005), pp. 231 238.

Lau C, Anitole K, Hodes C, Lai D, Pfahles-Hutchens A, Seed J. 2007, Perfluoroalkyl acids: a review of monitoring and toxicological findings, Toxicol. Sci. 99 (2007), pp. 366-394.

Lau, C, Anitole, K., Hodes, C, Lai, D., Pfahles-Hutchens, A., and Seed, J. (2007). Perfluoroalkyl acids: A review of monitoring and toxicological findings. Toxicol. Sci. 99(2), 366-394.

Lehmler HJ, 2005 Synthesis of environmentally relevant fluorinated surfactants a review, Chemosphere 58 (2005), pp. 1471-1496.

Lofstrand, K., Jorundsdottir, H., Tomy, G., Svavarsson, J.,Weihe, P.,Nygard, T., Bergman, K., 2008. Spatial trends of polyfluorinated compounds in guillemot (Uria aalge) eggs from North-Western Europe. Chemosphere 72, 1475-1480.

Luebker DJ, Hansen KJ, Bass NM, Butenhoff JL, Seacat AM, Interactions of fluorochemicals with rat liver fatty acid-binding protein, Toxicology, 176 (2002), pp. 175-185.

Martin, J. W.; Whittle, D. M.; Muir, D. C. G.; Mabury, S. A. Perfluoroalkyl contaminants in a food web from lake Ontario. Environ. Sci. Technol. 2004, 38, 5379-5385.

Martin JW, Mabury SA, O'Brien PJ, 2005. Metabolic products and pathways of fluorotelomer alcohols in isolated rat hepatocytes, Chemico-Biol. Interactions 155 (2005), pp. 165-180.

Nabb DL, Szostek B, Himmelstein MW, Mawn MP, Gargas ML, Sweeney LM, Stadler JC, Buck RC, Fasano WJ, 2007. In-vitro metabolism of 8-2 fluorotelomer alcohol: interspecies comparison and metabolic pathway refinement, Toxicol. Sci. 100(2007), pp. 333-344.

Norstrom, R. J.; Simon, M.; Moisey, J.; Wakeford, B.; Weseloh, D. V. C. Geographical distribution (2000) and temporal trends (1981-2000) of brominated diphenyl ethers in Great Lakes herring gull eggs. Environ. Sci. Technol. 2002, 36, 4783-4789.

O'Brien JM, Crump D, Mundy LJ, Chu S, McLaren KK, Vongphachan V, Letcher RJ, Kennedy SW.Pipping success and liver mRNA expression in chicken embryos exposed in ovo to $\mathrm{C} 8$ and $\mathrm{C} 11$ perfluorinated carboxylic acids and $\mathrm{C} 10$ perfluorinated sulfonate. Toxicol Lett. 2009 Oct 28; 190(2): 134-9. 
OECD 2002. (Organization for Economic Co-operation and Development), 2002. Co-operation on existing chemicals. Hazard assessment of perfluorooctane sulfonate (PFOS) and its salts. ENV/JM/RD(2002)17/FINAL, Paris.

OECD 2005. (Organization for Economic Co-operation and Development), 2005. Results of survey on production and use of PFOS, PFAS and PFOA, related substances and products/mixtures containing these substances. ENV/JM/MONO(2005)1, Paris.

Olsen GW, Mair DC, Reagan WK, Ellefson ME, Ehresman DJ, Butenhoff JL, Zobel LR, 2007a. Preliminary evidence of a decline in perfluorooctanesulfonate (PFOS) and perfluorooctanoate (PFOA) concentrations in American Red Cross blood donors, Chemosphere 68 (2007), pp. 105-111.

Olsen GW, Burris JM, Ehresman DJ, Froehlich JW, Seacat AM, Butenhoff JL, Zobel LR, 2007b. Half-life of serum elimination of perfluorooctanesulfonate, perfluorohexanesulfonate, and perfluorooctanoate in retired fluorochemical production workers, Environ. Health Perspect. 115 (2007), pp. 1298-1305.

Prevedouros K. Cousins IT, Buck RC, Korzeniowski SH. 2006. Sources, fate and transport of perfluorocarboxylates. Environmental Science and Tecnhology 40:32-44.

Richardson, S.J., Bradley, A.J., Duan, W., Wettenhall, R.E.H., Harms, P.J., Babon, J.J., 1994. Evolution of marsupial and other vertebrate thyroxine-binding plasma proteins. Am. J. Physiol. 266, 1359-1370.

Richardson, S.J., Whettenhall, E.H., Schreiber, G., 1996. Evolution of transthyretin gene expression in the liver of Didelphis virginiana and other American marsupials. Endocrinol. 137, 3507-3512.

Schultz MM, Barovsky DF, Field JA. 2003. Fluorinated alkyl surfactants, Environ. Eng. Sci. 20 (2003), pp. 487-501.

Tao, L., Kannan, K., Kajiwara, N., Costa, M.M., Fillmann, G., Takahashi, S., Tanabe, S., 2006. Perfluorooctanesulfonate and related fluorochemicals in albatrosses, elephant seals, penguins, and polar skuas from the Southern Ocean. Environ. Sci. Technol. 40, 7642-7648.

Tomy GT, Tittlemier SA, Palace VP, Budakowski WR, Brarkevelt E, Brinkworth L Friesen K. 2004. Biotransformation of $\mathrm{N}$-ethyl perfluorooctanesulfonamide by rainbow trout (Onchorhynchus mykiss) liver microsomes, Environ. Sci. Technol. 38 (2004), pp. 758-762. 
US EPA, 2002. 3M Phase-out Plan for POSF-Based Products. Administrative Record AR 226-0600. United States Environmental Protection Agency, Washington, DC.

US EPA, 2005. Draft risk assessment of the potential human health effects associated with exposure to perfluorooctanoic acid and its salts. OPPT review, http://www.epa.gov/oppt/pfoa/pubs/pfoarisk.pdf [accessed 4 January 2008].

Van de Vijver KI, Hoff P, Das K, Brasseur S, Van Dongen W, Esmans E, et al., 2005. Tissue distribution of perfluorinated chemicals in Harbor Seals (Phoca vitulina) from the Duch Wadden Sea, Environ Sci Technol 39 (2005), p. 6978.

Van Leeuwen, S. P. J., van der Veen, I., Leonards, P. E. G., and De Boer, J. (2006). Perfluorinated compounds in edible Dutch fish: A source for human exposure. Organohalogen Compd. 68, 535-538.

Verreault, J., Houde, M., Gabrielsen, G.W., Berger, U., Haukas, M., Letcher, R.J., Muir, D.C., 2005. Perfluorinated alkyl substances in plasma, liver, brain, and eggs of glaucous gulls (Larus hyperboreus) fromthe Norwegian arctic. Environ. Sci. Technol. 39, 7439-7445.

Verreault, J.; Berger, U.; Gabrielsen, G. W. Trends of perfluorinated alkyl substances in herring gull eggs from two coastal colonies in nothern Norway: 1983-2003. Environ. Sci. Technol. 2007, 41, 6671-6677.

Wang N, Stostek B, Folsom PW, Sulecki LM, Capka V, Buck RC, Berti WR, Gannon JT, 2005. Aerobic biotransformation of 14C-labeled 8-2 telomer B alcohols by activated sludge from domestic sewage treatment plant, Environ. Sci. Technol. 39 (2005), pp. 531-538.

Wang, Y., Yeung, L.W., Taniyasu, S., Yamashita, N., Lam, J.C., Lam, P.K., 2008. Perfluorooctane sulfonate and other fluorochemicals in waterbird eggs from south

China. Environ. Sci. Technol. 42, 8146-8151.

Weiss JM, Andersson PL, Lamoree MH, Leonards PEG, van Leeuwen SPJ, Hamers T. 2009. Competitive Binding of Poly- and Perfluorinated Compounds to the Thyroid Hormone Transport Protein Transthyretin. Tox Sci 109(2), 206-216 (2009)

Weseloh, D. V. C; Pekarik, C; De Solla, S. R. Spatial patterns and rankings of contaminant concentrations in Herring Gull eggs from 15 sites in the Great Lakes and connecting channels, 1998-2002. Environ. Monit. Assess. 2006, 113, 265284. 
Xiongjie S, Yeung LWY, Lam PKS, Wu RSS, Zhou B, 2009. Protein Profiles in Zebrafish (Danio rerio) Embryos Exposed to Perfluorooctane Sulfonate. Toxicological Sciences 110(2):334-340.

Xu L, Krenitsky DM, Seacat AM, Butenhoff JL, Anders MW. 2004. Biotransformation of $\mathrm{N}$-ethyl-N-(2-hydroxyethyl) perfluorooctanesulfonamide by rat liver microsomes, cytosol, and slices and by expressed rat and human cytochromes P450, Chem. Res. Toxicol. 17 (2004), pp. 767-775. 


\section{CHAPTER SEVEN}

\section{Conclusions and Future Directions}

\subsection{Conclusions}

The present gull TTR and albumin molecular characterization and competitive binding studies clearly showed that, although there are high amino acid sequence similarities among human and gull, and albumin and TTR, the human TH transport proteins cannot be used as a surrogate to assess the effects on circulating THs in wildlife, specifically birds such as the gull species (Laridae). Differences between human albumin and TTR for TH binding are several fold compared with herring gulls. The present study contributes with novel values, recording for the first time the binding affinities of gull albumin hormone transport protein binding $\mathrm{T} 3$ and $\mathrm{T} 4$, and observed through a set of environmentally relevant contaminants found in circulating plasma of gulls (organohalogens and perfluorinated compounds). It was observed in this research that $\mathrm{OH}$-metabolites either chlorinated or brominated had higher binding affinity than THs to albumin and TTR. This indicates that the combination of the more TH-like brominated diphenyl ether backbone (relative to the chlorinated biphenyl backbone), and in combination of having an $\mathrm{OH}$-group, results to more effective competitive ligand on gull hormone transport proteins relative to both T3 and T4. A more complex 
ligand-binding parameter assessment (e.g. complex chemical mixtures) for $\mathrm{TH}$ transport protein in gull species, and in wildlife in general, are necessary to fully understanding the potential effects in reproductive, nutritional and physiological processes that could be influenced by changes in the circulating T4 and T3, and subsequently $\mathrm{TH}$-dependent processes.

During this research investigation, molecular cloning, expression and purification of TTR and ALB was performed and was successful, and rec proteins could be used to assess two specific gull species, and then compared with human $\mathrm{TH}$ transport proteins (ALB and TTR) to observe binding affinities and potencies in the presence of various exogenous ligands and byproducts that theoretically and potentially could disrupt thyroid activities.

In this research, it was observed that PBDEs concentrations appears to follow the historical increase that has been previously reported for the Great Lakes Area, and thesis contributes with new data of brominated flame retardants concentrations found in analyzed livers and plasma of herring gulls. This is the first report of hydroxylated-PCBs/PBDEs (OH-PCBs and $\mathrm{OH}$ PBDEs), and Methoxylated brominated diphenyl ethers (£MeO-PBDEs) in circulating plasma and livers of Herring gulls from two selected colonies at Lake Ontario. To my knowledge, there were no previous reports on circulating OH-PCB, OH-PBDE, PBDE and MeO-PBDEs in herring gulls from the Laurentian Great Lakes. This is 
the first report of concentrations of 6-OH-BDE47 and 4'-OH-BDE49 in plasma of herring gulls with values up to $1.1 \pm 0.62 \mathrm{ng} / \mathrm{g}$ (wet weight), which is $-0.002 \mathrm{nM}$.

Using an in vitro competitive binding analysis I used two extracted and selected phenolic and neutral fractions as complex chemical mixtures to observe a disruption in the binding of THs T3 or $\mathrm{T}_{4}$ with TTR and albumin from gulls and humans. Differences were observed in the response of TH transport proteins among humans and herring gulls and among fractions, where phenolic fractions presented the higher affinity.

In contrast to OH-PBDEs, the mean concentrations of $4-\mathrm{OH}-\mathrm{CB} 187$ in the plasma of herring gull from Hamilton harbour was up to $37.5 \mathrm{ng} / \mathrm{g} w \mathrm{w}$ (and 30.1 $\mathrm{ng} / \mathrm{g}$ ww for Scotch Bonnet Island), which is $-0.09 \mathrm{nM}$ and the the competitive potency (IC50) was -5-10 nM for 4-OH-CB187 for $\mathrm{T}_{3}$ and $\mathrm{T}_{4}$ on gullTTR, and -1-5 $\mathrm{nM}$ with gull albumin. The 4-OH-CB187 levels found in herring gulls in Lake Ontario during this study may be high enough to effect circulating $T_{3}$ or T4 levels, according to the observations during the competitive binding assays. Also, during this research, the patterns and levels of exposure to these $\mathrm{OH}$-containing contaminants did not differ between the two colonies of birds (liver and plasma), therefore the potential effects on circulating T3 and T4 are the same for both areas. It is possible that levels of contaminants circulating in herring gull blood (and stored in liver) could disrupt TH homeostasis (to the fact that albumin had higher binding affinity than TTR), with consequently susceptibility of displacement 
by competition by hydroxylated compounds such as $\mathrm{OH}-\mathrm{PCBs}$ or $\mathrm{OH}-\mathrm{PBDEs}$, that had show higher binding affinity.

It is also possible, that an influence and/or change on the cellular TH levels and the ratio of $\mathrm{T} 3$ and $\mathrm{T}_{4}$ could affect the $\mathrm{TH}$ homeostasis (Mendel, 1989), and the $\mathrm{TH}$-dependent function and as consequence the health of exposed organisms. In birds and other wildlife, the competitive xenobiotic displacement of T4 from ALB or TTR would result in less T4 available to target tissues, and a subsequent diminish in the concentration of T4 substrate for deiodinase enzymes, including the $5^{\prime}$ deiodinases $\mathrm{DI}$ and $\mathrm{DM}$. The lack of substrate $\mathrm{T} 4$ for deiodinases will have a direct effect in the T4 conversion to active $T_{3}$ and then a smaller concentration availability of T3 to thyroid receptors and targeted tissues (Brouwer et al., 1998; Verhoelst et al., 2005). In mammals for example, OH-PCB (4-hydroxy-2',3,3',4',5pentachlorobipheny) binding affinity using rat liver cytosol and T2 suggested that the nature of the T2 sulfation inhibition is competitive (Schuur et al. 1998).

The present results also demonstrate that there are potential physiological consequences of the $\mathrm{OH}$-containing organohalogens competitive binding to herring gull albumin and TTR. In birds the displacement of T4 from ALB or TTR would provide more $T_{4}$ to target tissues and would increase the amount of substrate for deiodinase enzymes, including the 5' deiodinases $\mathrm{DI}$ and $\mathrm{DM}$, which can convert $T_{4}$ to its active form T3 (Verhoelst et al., 2005). Like other bird species, gulls not only have TTR but also ALB, which also bind and are involved 
in the transportation of thyroid hormones. However, relaying only in the context of overall thyroid hormone binding and transportation in birds, TTR may be of lesser importance than albumin. In birds, the proportion of circulating TH-binding transport proteins is low for TTR (McNabb et al, 1998). McNabb (2000) reported that in chicken the circulating $T_{4}$ is bound $75 \%$ to ALB, $17 \%$ to TTR and $7.5 \%$ to a a-globulin.

$T_{4}$ and particularly the primary metabolically active $T_{3}$ are considered the prime controllers for the regulation of metabolic functions and thermogenesis in mammals and birds (McNabb and Fox, 2003). $\mathrm{T}_{4}$ and T3 are suspected to be involved in a partial dissipation of the mitochondrial proton electrochemical gradient that would uncouple phosphorylation from oxidation and hence produce heat. Therefore, high concentrations of contaminants in mammals and birds that alter circulating $\mathrm{TH}$ status could potentially affect temporally or permanently the basal metabolism and the capacity for adaptive thermogenesis.

Perfluorinated compounds on the other hand are a novel compounds, with just recent interest in the study of their capacity to disrupt or affect the Thyroid systems. In this perspective study of PFCs, differences were observed in the response of $\mathrm{TH}$ transport proteins among humans and herring gulls and among the selected complex mixtures. The acidic fraction in competitive binding was able to disrupt human and gull TTR binding T3 and $T_{4}$. Neutral extractions appear 
to have effects mainly in T4 when binds albumin either from humans or gulls, however higher disruption was observed in human TTR.

PFOSA compound appears to have more disruption effects of human TTR when binding $T_{4}$. PFUdA compound affects and disrupt human and gull TTR in the binding of T4, but apparently does not have effect when is binding $T_{3}$. This investigation contributes with the first report of PFCs concentrations in livers of Herring gulls from the Great Lakes sampled in Lake Ontario two colonies (Hamilton Harbour and Scotch Bonnet Island).

\subsection{Future directions}

It is necessary to investigate tetra and pentachlorobiphenyl in liver cytosol in avians, due to the importance of the homeostasis in bird development, and reproduction. It has been observed in mammals, that OH-PCB (4-hydroxy2',3,3',4',5-pentachlorobiphenyl, 4-OH-CB107) binding affinity using liver cytosol and T2 suggested that the nature of the T2 sulfation inhibition is competitive. In my suggestion, there are big gaps of knowledge in the sulfation and deiodination, and enzymatic reactions and relation in the process of the thyroid hormones to address.

PFCs in this preliminary screening of binding affinity capacity with thyroid hormones had higher disruption effects in human TTR than birds. Albumin is the 
most important transporter in avian, but even accounts for the binding of approximately $10 \%$ of circulating thyroid hormone in humans, recent observations suggest that circulating serum albumin tightly binds PFCs. Recent findings suggest that oral dosing in rats with PFOS results in transiently increased tissue availability of the thyroid hormones and turnover of T4 with a resulting reduction in serum $\mathrm{TT}_{4}$. Further investigations of PFCs compounds that are structurally homologous to free fatty acids are necessary (e.g. Cellular and membrane transportation). Questions need to be addressed about if they compete for serum protein binding sites in vivo and the description of the values of their binding affinity assessment in vitro.

New sets of ligands binding parameter assessments for TH transport protein in Larus argentatus, and in wildlife in general, are necessary to more fully understanding the potential effects in reproductive, nutritional, physiological and environmental (e.g., temperature) factors that can influence circulating T4 and T3 and subsequently on TH-depending processes. Ligands such as complex chemical extractions and the interactions of the two major TH transport proteins in birds, and in a-globulin. Further studies investigating the role of a-globulin are also necessary. Improving binding assays to a even more real environmental situations are necessary to observe interactions among thyroid hormones, ligands and $\mathrm{TH}$ transporters. 
Investigations are also needed observing if there are changes in plasma thyroid hormone concentrations, mostly the depression of circulating $T_{4}$ concentrations due to exposure to $\mathrm{OH}-\mathrm{PCBs} / \mathrm{OH}-\mathrm{PBDEs}$ in vivo and to deep investigate the consequence of several modes of action. First, to understand if exist a direct effect on the thyroid gland, both on thyroid gland morphology and on iodine transporters in the thyroid gland that can lead to a decreased synthesis of thyroid hormones by Hydroxylated compounds. Secondly, an altered metabolism of thyroid hormones, such as an increased biliary excretion of $T_{4}$, can decrease thyroid hormone concentrations. Thirdly, binding of OH-PCBs/PBDEs to the plasma thyroid hormone transport proteins can result in a displacement of the natural ligand of T4 in vitro, but we need to know the possible reaction in vivo. And, finally, interference of OH-PCBs/PBDEs with binding of thyroid hormones on their receptors has been described in vitro, but is necessary to include more elements such as direct observation in the iodine uptake at the thyroid gland, and their possible effect through changes in he sodium iodide symporter (NIS) which mediates iodide transport into cells.

Finally I will suggest further studies to observe effects e.g., in-vitro sub cellular and organohalogen compounds correlations at the in vivo (whole organism) level in free-ranging wildlife where $\mathrm{TH}$-dependent effects are suggestive (for example in Arctic wildlife including birds) (Letcher et al., 2010). There is a lack of studies that have examined complex organohalogen exposures; and even fewer that have addressed competitive binding assays with $\mathrm{TH}$ and $\mathrm{TH}$ transport protein 
interactions. More experiments are needed to address the differences on species and population specifics such as $\mathrm{TH}$-related effects with $\mathrm{TH}$ transport proteins and confounding factors: (i) physiological status and timing (e.g., reproductively active); (ii) sensitivity as a function of other stressors (e.g., climate change), (iii) deleterious (chronic) effects and risks at organism or population levels.

\subsection{References}

Brouwer A, Morse DC, Lans MC, Schuur AG, Murk AJ, Klasson-Wehler E. 1998. Interactions of persistent environmental organohalogens with the thyroid hormone system: mechanisms and possible consequences for animal and human health. Toxicol. Ind. Health. 14: 59-84.

Letcher RJ, Bustnes JO, Dietz R, Jenssen BM, Jorgensen $E H$, Sonne $C$, Verreault J, Vijayan M, Gabrielsen GW, 2010. Exposure and effects assessment of persistent organic pollutants in Arctic wildlife and fish. Sci. Total. Environ. submitted.

McNabb FM, Fox A, Fox GA, 2003. Avian thyroid development in chemically contaminated environments: is there evidence of alterations in thyroid function and development? Evolution \& Development. 5(1): 75-76.

McNabb FMA, Scanes CG, Zeman M, 1998. Endocrine control of development. In: Starck, J.M. and Ricklefs, R.E., Editors, 1998. Avian Growth and Development, Oxford University Press, New York, pp. 174-202.

McNabb FMA. 2000. Thyroids. In: Sturkie's Avian Physiology (Whittow GC, ed). 5th ed. London:Academic Press, 461-471.

Mendel CM, 1989. The free hormone hypothesis: a physiologically based mathematical model. Endocrinol Rev 10: 232-274.

Schuur AG, Legger FF, Van Meeteren ME, Moonen MJH, Van Leeuwen-Bol I, Bergman A, 1998. In vitro inhibition of thyroid hormone sulfation by hydroxylated metabolites of halogenated aromatic hydrocarbons. Chem Res Toxicol 11: 10751081.

Verhoelst CHJ, Van der Geyten S, Roelens SA, Darras VM, 2005. Regulation of thyroid hormone availability by iodothyronine deiodinases at the blood-brain barrier in birds, Ann. N.Y. Acad. Sci. 1040: 501-503. 


\section{APPENDICES}

Appendix I. Concentration levels of organohalogens and metabolites analyzed in plasma and liver of two herring gull colonies in Lake Ontario, Canada.

\begin{tabular}{|c|c|c|c|c|c|c|c|c|}
\hline \multirow[b]{2}{*}{$\mathrm{ng} / \mathrm{gr}$ ww } & \multirow[b]{2}{*}{$\begin{array}{c}\mathrm{HH} \\
\text { plasma }\end{array}$} & \multirow[b]{2}{*}{$\begin{array}{l}\mathrm{HH} \\
\text { liver }\end{array}$} & \multirow[b]{2}{*}{$\begin{array}{c}\text { SBI } \\
\text { plasma }\end{array}$} & \multirow[b]{2}{*}{$\begin{array}{l}\text { SBI } \\
\text { liver }\end{array}$} & & & & \\
\hline & & & & & $\begin{array}{c}\mathrm{HH} \\
\text { plasma }\end{array}$ & $\begin{array}{l}\text { HH } \\
\text { liver }\end{array}$ & $\begin{array}{c}\text { SBI } \\
\text { plasma }\end{array}$ & $\begin{array}{l}\text { SBI } \\
\text { liver }\end{array}$ \\
\hline 1,2,4,5-Tetrachloroben... & nd & nd & nd & nd & 0 & 0 & 0 & 0 \\
\hline 1,2,3,4-Tetrachloroben... & nd & nd & nd & nd & 0 & 0 & 0 & 0 \\
\hline Pentachlorobenzene & 1.78 & 1.89 & 0.29 & 0.32 & 60 & 70 & 100 & 100 \\
\hline a-Hexachlorocyclohexane & nd & nd & nd & nd & 0 & 0 & 0 & 0 \\
\hline Hexachlorobenzene & 19.6 & 14.5 & 2.97 & 3.12 & 100 & 70 & 80 & 90 \\
\hline B-Hexachlorocyclohexane & nd & nd & nd & nd & 0 & 0 & 0 & 0 \\
\hline Y-Hexachlorqc^clohexane & nd & nd & nd & nd & 0 & 0 & 0 & 0 \\
\hline Sum of I & 21.3 & 16.3 & 3.26 & 3.44 & & & & \\
\hline Octachlorostyrene & nd & 21.5 & nd & nd & 0 & 30 & 0 & 0 \\
\hline Heptachlor.epoxide & nd & 3.35 & nd & nd & 0 & 30 & 0 & 0 \\
\hline Oxychlordane & nd & 10.1 & nd & 2.56 & 0 & 40 & 0 & 30 \\
\hline t-Chlordane & nd & nd & nd & nd & 0 & 0 & 0 & 0 \\
\hline c-Chlordane & nd & nd & nd & nd & 0 & 0 & 0 & 0 \\
\hline t-Nonachlor & 3.94 & 28.1 & 0.83 & 7.42 & 70 & 80 & 100 & 80 \\
\hline$p, p^{\prime}-D D E$ & 296 & 2486 & 76 & 623 & 70 & 90 & 80 & 70 \\
\hline Dieldrin & nd & nd & nd & nd & 0 & 0 & 0 & 0 \\
\hline p,p'-DDD & 1.91 & 15.5 & 0.31 & 2.32 & 80 & 100 & 60 & 80 \\
\hline c-Nonachlor & 4.25 & 51.1 & 0.78 & 10.6 & 70 & 80 & 100 & 90 \\
\hline p,p'-DDT & 19.7 & 477 & 20.5 & 225 & 80 & 100 & 60 & 100 \\
\hline Photomirex & 59.8 & 430 & 20.5 & 221 & 100 & 100 & 70 & 100 \\
\hline Mirex & 128 & 1046 & 21.1 & 152 & 100 & 100 & 100 & 70 \\
\hline TCPM & nd & nd & nd & nd & 0 & 0 & 0 & 0 \\
\hline \multirow[t]{2}{*}{ Sum of 2} & 513 & 4568 & 140 & 1243 & & & & \\
\hline & $\begin{array}{c}\mathrm{HH} \\
\text { plasma }\end{array}$ & $\begin{array}{l}\text { HH } \\
\text { liver }\end{array}$ & $\begin{array}{c}\text { SBI } \\
\text { plasma }\end{array}$ & $\begin{array}{l}\text { SBI } \\
\text { liver }\end{array}$ & $\begin{array}{c}\mathrm{HH} \\
\text { plasma }\end{array}$ & $\begin{array}{c}\mathrm{HH} \\
\text { liver }\end{array}$ & $\begin{array}{c}\text { SBI } \\
\text { plasma }\end{array}$ & $\begin{array}{l}\text { SBI } \\
\text { liver }\end{array}$ \\
\hline$p, p^{\prime}-D D D$ & 1.91 & 15.5 & 0.31 & 2.33 & 80 & 100 & 60 & 80 \\
\hline$p, p^{\prime}-D D E$ & 296 & 2486 & 76 & 623 & 70 & 90 & 80 & 70 \\
\hline p,p'-DDT & 19.7 & 477 & 20.5 & 225 & 80 & 100 & 60 & 100 \\
\hline Sum of 2 & 317 & 2978 & 96.8 & 850 & & & & \\
\hline Photomirex & 59.8 & 430 & 20.5 & 221 & 100 & 100 & 70 & 100 \\
\hline Mirex & 128 & 1046 & 21.1 & 152 & 100 & 100 & 100 & 70 \\
\hline Sum of 1 & 187 & 1476 & 41.6 & 373 & & & & \\
\hline
\end{tabular}


Internal Std

13C-Tetrachlorobenzene

13C-Pentachlorobenzene

13C-Hexachlorobenzene

$13 C-p, p^{\prime}-D D E$
MLOQ $<0.10-0.25 \mathrm{ng} / \mathrm{gr}$ ww for blood and liver

$\mathrm{nd}=$ Not detected ng/gr ww

PCB-18

PCB-17

PCB-16/32

PCB-31

PCB-28

PCB-33/20

PCB-22

PCB-52

PCB-49

PCB-47/48

PCB-44

PCB-42

PCB-64/41

PCB-74

PCB-70/76

PCB-95

PCB-66

PCB-56/60

PCB-92

PCB-101/90

PCB-99

PCB-97

PCB-87

PCB-85

PCB-110

PCB-151

PCB-149

PCB-118

PCB-114

PCB-146

PCB-153

PCB-105

PCB-179

PCB-141

PCB-130

PCB-176

PCB-137

PCB-138

PCB-158

PCB-178 plas

1.81

1.06

2.25

3.59

13.9

12.8

1.78

1.43

2.59

8.29

1.41

3.31

1.99

11.5

24.5

4.38

21.4

3.34

0.93

4.49

10.9

1.06

1.57

2.26

5.88

0.38

2.98

60.6

0.1

15.2

168

14.7

0.1

4.85

4.56

0.22

3.99

162

11.7

2.72
HH
liver

12.9

12.9

22.5

25.7

103

107

10.4

10.2

12.1

82.7

16.1

33.6

10.7

96.9

279

42.1

181

34.9

9.1

47.1

108

19.1

8.15

23.3

48.4

2.79

30.1

583

1.23

153

1619

116

0.1

47.9

38.1

2.41

26.9

1628

119

23.5
SBI
plasma

1.69

1.06

2.55

2.11

12.7

10.6

11.2

9.6

1.49

5.28

7.45

0.37

1.55

13.7

34.8

4.69

44.1

4.29

0.52

2.43

2.33

1.13

0.93

0.91

3.35

0.28

0.98

17.6

1.24

2.23

29.1

9.25

0.24

2.58

0.41

0.37

6.79

29.3

2.87

1.63 percentage: of sartiples

positives

$\begin{gathered}\text { SBI } \\ \text { liver }\end{gathered}$
11.8
10.2
26.3
18.1

$\mathrm{HH}$

plasma liver plasma liver

$\begin{array}{llll}100 & 80 & 70 & 90\end{array}$

$\begin{array}{llll}90 & 80 & 100 & 80\end{array}$

$\begin{array}{llll}70 & 90 & 80 & 100\end{array}$

$\begin{array}{llll}80 & 100 & 80 & 90\end{array}$

$\begin{array}{llll}90 & 90 & 80 & 70\end{array}$

$\begin{array}{llll}100 & 100 & 100 & 100\end{array}$

$\begin{array}{llll}100 & 100 & 90 & 100\end{array}$

$\begin{array}{llll}80 & 100 & 90 & 100\end{array}$

$\begin{array}{llll}100 & 100 & 90 & 100\end{array}$

$\begin{array}{llll}100 & 100 & 90 & 100\end{array}$

$\begin{array}{llll}90 & 100 & 80 & 100\end{array}$

$\begin{array}{llll}80 & 100 & 70 & 100\end{array}$

$\begin{array}{llll}80 & 100 & 80 & 90\end{array}$

$\begin{array}{llll}90 & 100 & 80 & 100\end{array}$

$\begin{array}{llll}100 & 100 & 100 & 100\end{array}$

$\begin{array}{llll}80 & 90 & 90 & 100\end{array}$

$\begin{array}{llll}100 & 100 & 100 & 100\end{array}$

$\begin{array}{llll}80 & 80 & 80 & 100\end{array}$

$\begin{array}{llll}70 & 80 & 70 & 90\end{array}$

$\begin{array}{llll}80 & 100 & 70 & 100\end{array}$

$\begin{array}{llll}80 & 100 & 70 & 90\end{array}$

$\begin{array}{llll}40 & 100 & 70 & 100\end{array}$

$\begin{array}{llll}60 & 100 & 60 & 80\end{array}$

$\begin{array}{llll}80 & 100 & 80 & 80\end{array}$

$\begin{array}{llll}70 & 80 & 70 & 80\end{array}$

$\begin{array}{llll}70 & 60 & 60 & 40\end{array}$

$\begin{array}{llll}40 & 80 & \mathbf{6 0} & 50\end{array}$

$\begin{array}{llll}80 & 100 & 80 & 100\end{array}$

$\begin{array}{llll}40 & 60 & 80 & 90\end{array}$

$\begin{array}{llll}70 & 100 & 80 & 70\end{array}$

$\begin{array}{llll}100 & 100 & 100 & 100\end{array}$

$\begin{array}{llll}80 & 80 & 60 & 100\end{array}$

$\begin{array}{llll}50 & 40 & 60 & 80\end{array}$

$\begin{array}{llll}40 & 80 & 50 & 30\end{array}$

$\begin{array}{llll}40 & 70 & 60 & 60\end{array}$

$\begin{array}{llll}30 & 70 & 60 & 60\end{array}$

$\begin{array}{llll}10 & 40 & 40 & 80\end{array}$

$\begin{array}{llll}80 & 90 & 80 & 100\end{array}$

$\begin{array}{llll}60 & 70 & 70 & 70\end{array}$

$\begin{array}{llll}80 & 60 & 70 & 70\end{array}$ 


$\begin{array}{lcccccccc}\text { PCB-187 } & 57.4 & 571 & 16.9 & 101 & 100 & 100 & 80 & 90 \\ \text { PCB-183 } & 16.3 & 127 & 5.31 & 43.9 & 80 & 100 & 80 & 70 \\ \text { PCB-128 } & 7.1 & 81.4 & 6.84 & 45.5 & 70 & 80 & 60 & 80 \\ \text { PCB-167 } & 2.19 & 20.8 & 2.71 & 27.1 & 50 & 60 & 30 & 80 \\ \text { PCB-174 } & 3.62 & 51.8 & 1.06 & 10.7 & 40 & 50 & 40 & 70 \\ \text { PCB-177 } & 4.59 & 31.8 & 3.12 & 21.2 & 40 & 60 & 50 & 80 \\ \text { PCB-202 } & 1.34 & 11.4 & 5.65 & 34.6 & 40 & 70 & 30 & 70 \\ \text { PCB-171 } & 7.68 & 67.6 & 1.61 & 16.7 & 80 & 90 & 90 & 100 \\ \text { PCB-156 } & 9.61 & 88.1 & 5.19 & 39.4 & 40 & 60 & 50 & 70 \\ \text { PCB-200 } & 3.76 & 37.1 & 0.65 & 5.69 & 20 & 50 & 20 & 40 \\ \text { PCB-157 } & 0.63 & 6.66 & 1.81 & 7.75 & 30 & 20 & 100 & 40 \\ \text { PCB-172 } & 7.41 & 75.9 & 2.42 & 18.6 & 60 & 60 & 60 & 80 \\ \text { PCB-180 } & 94.1 & 929 & 29.1 & 173 & 80 & 100 & 80 & 90 \\ \text { PCB-170/190 } & 53.1 & 560 & 12.1 & 106 & 100 & 100 & 100 & 100 \\ \text { PCB-189 } & 5.06 & 48.6 & 4.92 & 33.8 & 70 & 80 & 80 & 100 \\ \text { PCB-199 } & 5.86 & 45.5 & 10.7 & 84.7 & 70 & 70 & 80 & 80 \\ \text { PCB-196/203 } & 3.67 & 32.4 & 4.32 & 11.1 & 80 & 80 & 60 & 80 \\ \text { PCB-208 } & 0.55 & 4.49 & 0.51 & 5.68 & 30 & 50 & 50 & 40 \\ \text { PCB-195 } & 1.86 & 8.28 & 1.78 & 8.21 & 40 & 50 & 30 & 30 \\ \text { PCB-207 } & 2.34 & 32.1 & 0.55 & 3.88 & 60 & 60 & 40 & 70 \\ \text { PCB-194 } & 4.52 & 37.9 & 3.73 & 28.3 & 60 & 70 & 70 & 70 \\ \text { PCB-206 } & 1.66 & 10.1 & 0.41 & 3.85 & 70 & 60 & 50 & 60 \\ \text { sum of 2 } & \mathbf{8 9 4} & \mathbf{8 6 2 6} & \mathbf{4 0 7} & \mathbf{3 2 4 0} & & & & \end{array}$

Internal Std

MOQ $<0.10-0.25 \mathrm{ng} / \mathrm{gr}$ ww' for blood and liver

13C-PCB-28

$\mathrm{nd}=$ Not detected

13C-PCB-52

13C-PCB-118

13C-PCB-153

13C-PCB-180

13C-PCB-194

\begin{tabular}{|c|c|c|c|c|c|c|c|c|}
\hline \multirow[t]{3}{*}{$n g / g r$ ww } & & & & & \multicolumn{4}{|c|}{$\begin{array}{l}\text { percentage of samples } \\
\text { positives }\end{array}$} \\
\hline & $\mathrm{HH}$ & $\mathrm{HH}$ & SBI & SBI & $\mathrm{HH}$ & $\mathrm{HH}$ & SBI & SBI \\
\hline & plasma & liver & plasma & liver & plasma & liver & plasma & liver \\
\hline BDE-17 & nd & 9.52 & nd & 3.56 & 0 & 20 & 0 & 60 \\
\hline BDE-28 & 2.12 & 17.2 & 1.24 & 8.54 & 60 & 60 & 50 & 70 \\
\hline BDE-49 & 1.54 & 19.5 & 0.33 & 2.56 & 50 & 50 & 30 & 60 \\
\hline BDE-47 & 20.1 & 268 & 28.1 & 312 & 80 & 90 & 80 & 100 \\
\hline BDE-66 & nd & 5.62 & nd & 2.53 & 0 & 20 & 0 & 30 \\
\hline BB-101 & 1.61 & 7.96 & 0.54 & 4.25 & 40 & 40 & 30 & 50 \\
\hline BDE-100 & 31.7 & 332 & 8.88 & 97.6 & 80 & 90 & 80 & 80 \\
\hline BDE-99 & 43.1 & 430 & 11.4 & 122 & 100 & 100 & 80 & 100 \\
\hline BDE-85 & 2.45 & 18.5 & 0.45 & 3.89 & 30 & 40 & 40 & 50 \\
\hline BDE-154/BB153 & 32.1 & 317 & 3.31 & 38.4 & 80 & 100 & 70 & 100 \\
\hline BDE-153 & 49.2 & 490 & 6.51 & 71.5 & 100 & 100 & 80 & 90 \\
\hline HBCDD & nd & nd & nd & nd & 0 & 0 & 0 & 0 \\
\hline BDE-138 & 1.25 & 8.56 & 0.56 & 4.58 & 40 & 40 & 30 & 50 \\
\hline BDE-183 & 3.77 & 43.6 & nd & 13.1 & 60 & 70 & 0 & 50 \\
\hline
\end{tabular}




$\begin{array}{lcccccccc}\text { BDE-190 } & 2.53 & 18.52 & 1.14 & 9.56 & 60 & 70 & 30 & \mathbf{5 0} \\ \text { BDE209 } & 1.12 & 8.96 & 0.45 & 3.89 & 60 & 60 & 20 & \mathbf{4 0} \\ & & & & & & & & \end{array}$

Internal Std

BDE-30

ng/gr ww

PCP

4-MeO-HpCS

4'MeO-CB79

4'MeO-CB120

2'MeO-CB114

3MeO-CB118

$4 \mathrm{MeO}-$

CB107/4'MeO-

CB108

4 'MeO-CBIOI

4MeO-CB134

3'MeO-CB184

4MeO-CB146

4'MeO-CB127

3'MeO-CB138

4'MeO-CB130

4MeO-CB163

4MeO-CB178

3'MeO-CB182

3'MeO-CB183

$4 \mathrm{MeO}-\mathrm{CB} 187$

4MeO-CB97

4'MeO-CB159

4MeO-CB162

4'MeO-CB202

4'MeO-CB177

4'MeO-CB201

3'MeO-CB180

4'MeO-CB172

$4 \mathrm{MeO}-\mathrm{CB} 193$

3'MeO-

CB203/4MeOCB198

4'MeO-CB199

4'MeO-CB200

4,4'diMeO-CB202
Plasma

$\mathrm{HH}$

nd

nd

nd

nd

nd

nd

nd

nd

nd

nd

nd

nd

nd

nd

nd

nd

nd

nd

nd

nd

nd

nd

nd

nd

nd

nd

nd

nd

nd

nd

nd

nd
MLOQ $<\mathbf{0 . 1 0 - 0 . 2 5 ~} \mathrm{ng} / \mathrm{gr}$ ww for blood and liver

$\mathrm{nd}=$ Not detected
50

40 percentage of samples

positives

$\begin{array}{cccc}\begin{array}{c}\text { Plasma } \\ \text { HH }\end{array} & \text { SBI } & \begin{array}{c}\text { Liver } \\ \text { HH }\end{array} & \text { SBI } \\ 0 & 0 & 0 & 0 \\ 0 & 0 & 0 & 0 \\ 0 & 0 & 0 & 0 \\ 0 & 0 & 0 & 0 \\ 0 & 0 & 0 & 0 \\ 0 & 0 & 0 & 0\end{array}$

SBI

nd

nd

nd

nd

nd

nd

nd nd

nd nd

nd nd

nd nd

nd nd

nd nd

nd nd

nd nd

nd nd

nd nd

nd nd

nd nd

nd nd

nd nd

nd nd

nd nd

nd nd

nd nd

nd nd

nd nd

nd nd

nd nd

nd nd

nd nd

nd nd

nd nd

nd nd

nd

nd

nd

nd

nd

nd

nd

nd

nd

nd

nd

nd

nd

nd

nd

nd

nd

nd

nd

nd

nd

nd

nd

nd

nd nd

$\begin{array}{llll}0 & 0 & 0 & 0 \\ 0 & 0 & 0 & 0 \\ 0 & 0 & 0 & 0 \\ 0 & 0 & 0 & 0 \\ 0 & 0 & 0 & 0 \\ 0 & 0 & 0 & 0 \\ 0 & 0 & 0 & 0 \\ 0 & 0 & 0 & 0 \\ 0 & 0 & 0 & 0 \\ 0 & 0 & 0 & 0 \\ 0 & 0 & 0 & 0 \\ 0 & 0 & 0 & 0 \\ 0 & 0 & 0 & 0 \\ 0 & 0 & 0 & 0 \\ 0 & 0 & 0 & 0 \\ 0 & 0 & 0 & 0 \\ 0 & 0 & 0 & 0 \\ 0 & 0 & 0 & 0 \\ 0 & 0 & 0 & 0 \\ 0 & 0 & 0 & 0 \\ 0 & 0 & 0 & 0 \\ 0 & 0 & 0 & 0 \\ 0 & 0 & 0 & 0 \\ 0 & 0 & 0 & 0 \\ 0 & 0 & 0 & 0 \\ 0 & 0 & 0 & 0\end{array}$


to $\left.\left.\left.\mathrm{Ji} .-^{\wedge} U\right)-f^{\wedge}-\& \cdot W \quad U\right) \quad-P \wedge-f c . U>U\right)-t>-t>--\mid \wedge 0 J U>$

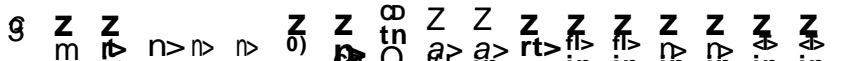

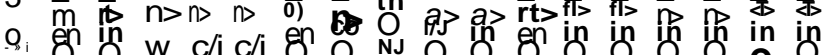

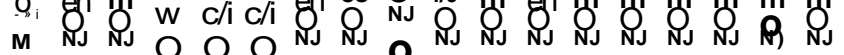

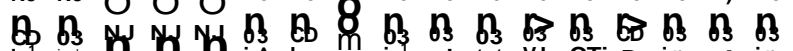

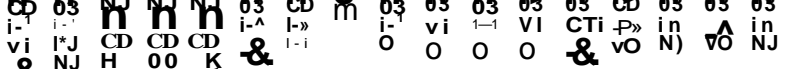

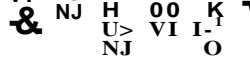

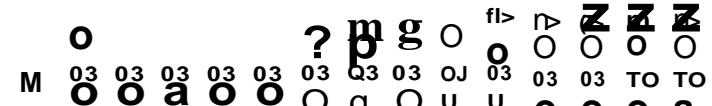

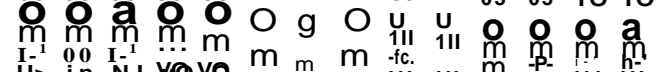

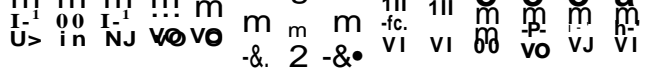
$\mathrm{M} \mathrm{Cg} \mathrm{vi}$

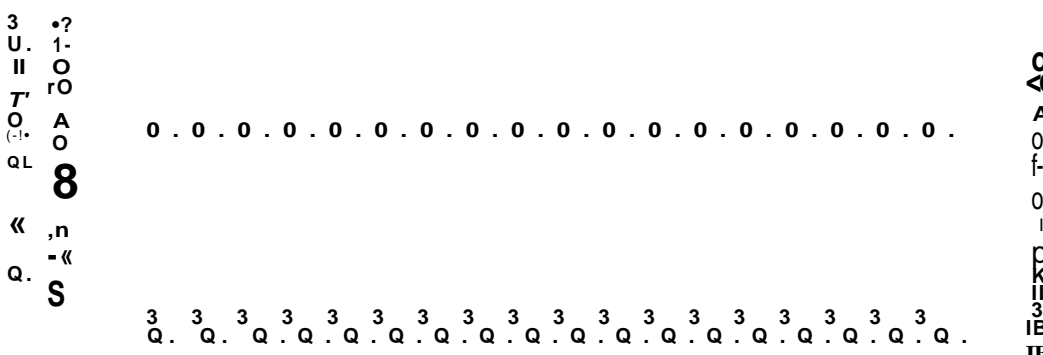

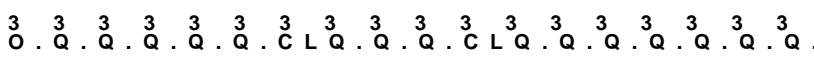
$0_{0}^{3} 0^{3} 0^{3} \cdot 0^{3} \cdot 0^{3} \cdot 0_{0}^{3} \cdot 0^{3} \cdot 0^{3} \cdot 0_{0}^{3} 0^{3} 0^{3} \cdot 0^{3} 0^{3} \cdot 0^{3} \cdot 0^{3} \cdot 0^{3} 0^{3} 0$ $\widehat{(10}$
0
$<0$
$A$
0
$f-1$
0
1
$p$
$k$
II
3
IB
IB

\begin{tabular}{l} 
o- \\
$\mathbf{0}$ \\
$\mathbf{0}$ \\
$\mathrm{a}$ \\
$\mathbf{B}$ \\
$\mathbf{a}$ \\
$\mathbf{a}$ \\
\hdashline \\
0
\end{tabular}
$\begin{array}{rrrrrrrrrrrrr}I Z 3 & 3 & 3 & 3 & 3 & 3 & 3 & 3 & 3 & 3 . & 3 & 3 \\ \mathbf{a} & \mathbf{a} & \mathbf{Q} & \mathbf{a} & \mathbf{a} & \mathbf{a} & \mathbf{a} & 0 & & & & \end{array}$

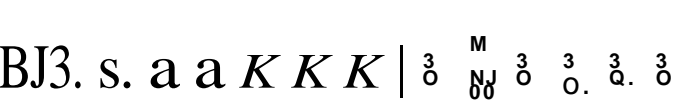

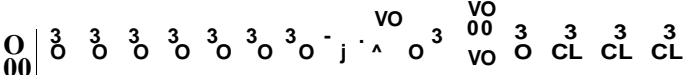

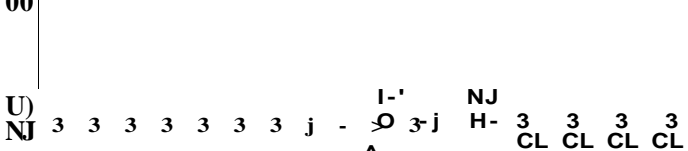
111 a a a a a a $\mathbf{a} \wedge$ a

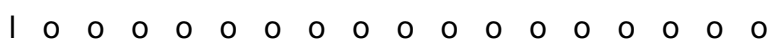

$\begin{array}{llllllllllllllllll}\text { I } & 0 & 0 & 0 & 0 & 0 & 0 & 0 & 0 & 0 & 0 & 0 & 0 & 0 & 0 & 0 & 0 & 0\end{array}$ j $0 \begin{array}{llllllllllllll} & 0 & 0 & 0 & 0 & 0 & 0 & g & 0 & g & 0 & 0 & 0 & 0\end{array}$

j j 0 o

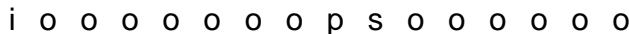

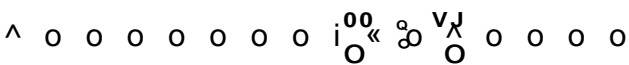

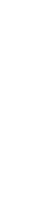




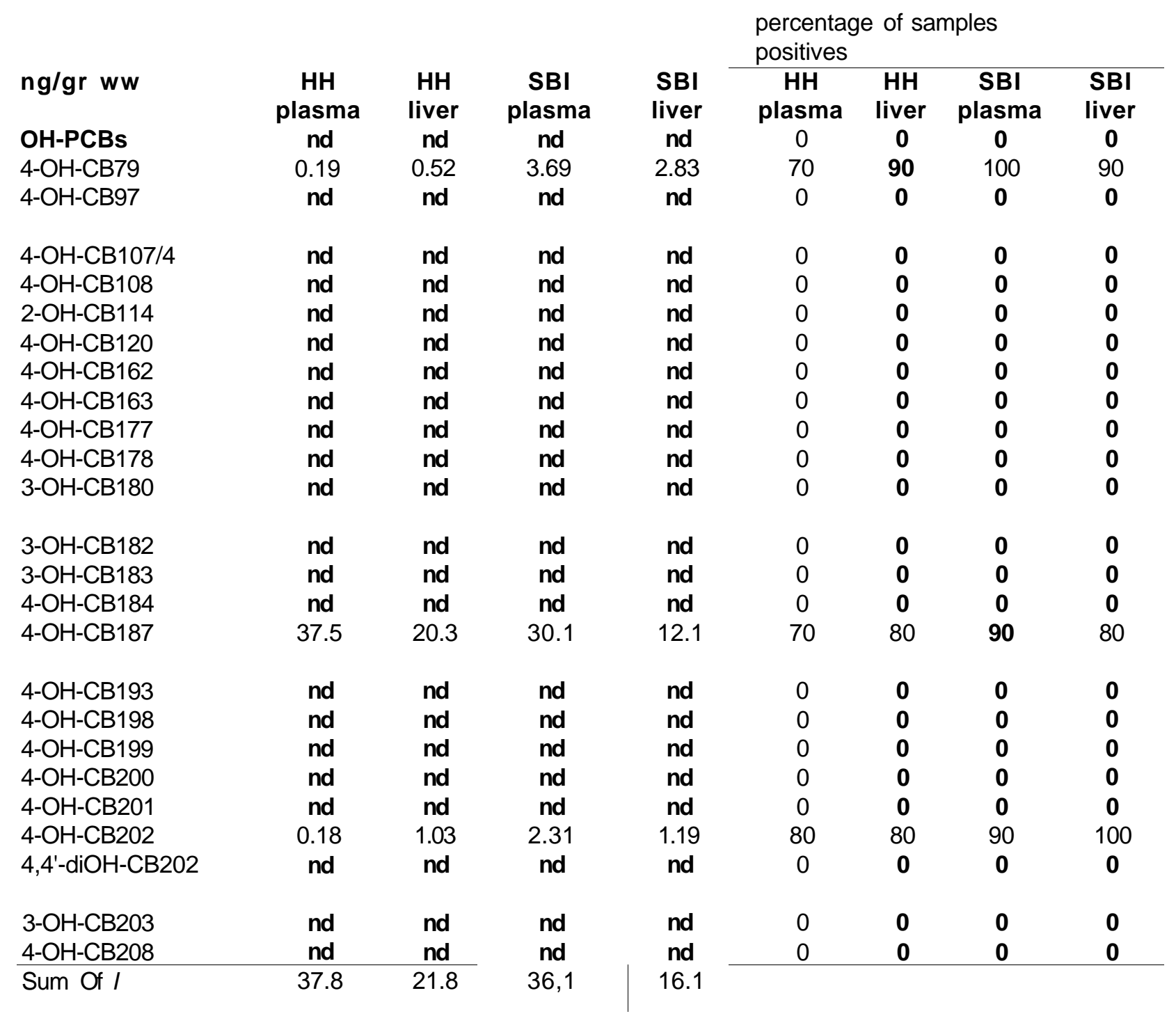

$M L O Q<0.02 \mathrm{ng} / \mathrm{gr}$ ww for blood and liver

\begin{tabular}{|c|c|c|c|c|c|c|c|c|}
\hline \multirow[b]{2}{*}{ OH-PBDES } & \multirow[b]{2}{*}{ Plasma } & \multirow[b]{2}{*}{ SBI } & \multirow[b]{2}{*}{ Liver } & & \multicolumn{3}{|c|}{$\begin{array}{l}\text { percentage of samples } \\
\text { positives }\end{array}$} & \multirow[b]{2}{*}{ SBI } \\
\hline & & & & SBI & $\begin{array}{c}\text { Plasma } \\
\text { HH }\end{array}$ & SBI & $\begin{array}{l}\text { Liver } \\
\text { HH }\end{array}$ & \\
\hline 6-OH-BDE17 & nd & nd & nd & nd & 0 & 0 & 0 & 0 \\
\hline 4-OH-BDE17 & nd & nd & nd & nd & 0 & 0 & 0 & 0 \\
\hline $6-\mathrm{OH}-\mathrm{CB} 107 / 4 \mathrm{OH}$ & & & & & & & & \\
\hline CB108 & nd & nd & nd & nd & 0 & 0 & 0 & 0 \\
\hline 2-OH-BDE68 & nd & nd & nd & nd & 0 & 0 & 0 & 0 \\
\hline 6-OH-BDE47 & 0.31 & 0.15 & 0.23 & 0.21 & 70 & 90 & 100 & 100 \\
\hline 3-OH-BDE47 & 0.1 & nd & nd & nd & 40 & 0 & 0 & 0 \\
\hline 5-OH-BDE47 & nd & nd & nd & nd & 0 & 0 & 0 & 0 \\
\hline 4-OH-BDE49 & 0.71 & 0.38 & 0.43 & 0.35 & 70 & 80 & 90 & 70 \\
\hline 4-OH-BDE42 & nd & nd & nd & nd & 0 & 0 & 0 & 0 \\
\hline 6-OH-BDE90 & nd & nd & nd & nd & 0 & 0 & 0 & 0 \\
\hline
\end{tabular}


6-OH-BDE99

2-OH-BDE123

6-OH-BDE85

6-OH-BDE137

Sum of I

Internal Std

$13 C-O H-P C B$
$0.06 \quad$ nd

nd nd

nd nd

nd nd

1.18 nd

nd

nd

nd

0.56

MLOQ $<0.05 \mathrm{ng} / \mathrm{gr}$ ww for blood and liver

$\mathrm{nd}=$ Not detected 